\title{
A CONFIGURAÇÃO ASSIMÉTRICA DO FEDERALISMO BRASILEIRO
}

Dissertação de Mestrado em Direito do Estado

Orientadora: Professora Doutora Fernanda Dias Menezes de Almeida

\author{
Faculdade de Direito da Universidade de São Paulo
}

São Paulo 


\section{A CONFIGURAÇÃO ASSIMÉTRICA DO FEDERALISMO BRASILEIRO}

Dissertação de Mestrado apresentada no Departamento de Direito do Estado da Faculdade de Direito da Universidade de São Paulo, como requisito parcial para a obtenção do título de Mestre em Direito do Estado.

Orientadora: Professora Doutora Fernanda Dias Menezes de Almeida

São Paulo 
"Enquanto houver Norte e Nordeste fracos, não haverá, na União, Estado forte, pois fraco é o Brasil”.

ULYSSES GUIMARÃES

(Discurso de promulgação da Constituição Federal de 05 de outubro de 1988) 
Para Evany BRASIL, que um dia cruzou meu caminho e, com gestos nobres, ensinou-me o quão transformadora é a força da educação, quando se acredita nela; e para José RUBENS TURINI, que fez de sua vida uma contínua lição de humildade, de vitória e de sabedoria. Ambos, apesar de não mais estarem entre nós, deixaram legados que ultrapassam as barreiras da existência, e que se revigoram diariamente nas lembranças de quem os conheceram. 


\section{AGRADECIMENTOS}

Mesmo ciente da impossibilidade de lembrar de todos que, de alguma forma, contribuíram para a concretização desta dissertação, não poderia deixar de remeter agradecimentos especiais a algumas pessoas cuja presença foi imprescindível para a consecução deste importante projeto em minha vida. Longe de serem exaustivos, os nomes abaixo elencados referem-se apenas àqueles que, de uma ou de outra forma, contribuíram mais de perto para o próprio fato de eu estar, agora, escrevendo estes agradecimentos. Isso não significa esquecimento de todos os outros que me ajudaram, em diferentes frentes, a concluir esta etapa.

Assim, em primeiro lugar, tenho de externar toda minha gratidão pela Professora Fernanda Dias Menezes de Almeida, que me encantou com suas aulas de Direito Constitucional quando eu ainda era aluno da Graduação na Faculdade de Direito da Universidade de São Paulo; e, agora, durante a indelével orientação que recebi no Curso de Pós-Graduação da mesma Instituição, fez-me sentir, permanentemente, seguro e confiante para prosseguir na pesquisa acadêmica e na confecção do trabalho aqui apresentado. Estou certo de que nenhum esforço que eu empreender conseguirá retratar o tamanho da admiração e o profundo respeito que lhe tenho; espero apenas, um dia, poder retribuir, em intensidade semelhante, toda confiança e atenção que dela sempre recebi.

Agradeço também os Professores Elival da Silva Ramos e José LeVi MEllo do AMARAL JUNIOR pelas valiosas orientações recebidas na banca de qualificação. Os apontamentos e as sugestões apresentados por ambos, sem dúvida, foram de grande contribuição no ajustamento dos caminhos a serem percorridos para concluir a confecção desta dissertação.

Aos meus pais, NilcE e SôniA; aos meus irmãos, RAFAEl e ANA CAROLINA; e à minha avó, ASSUMPTA, não me canso de dizer obrigado não somente por todo o esforço que fizeram para que eu pudesse prosseguir em minha formação, mas, principalmente, porque tiveram paciência e foram compreensivos em minhas reiteradas ausências. Em especial, agradeço meu pai e minha mãe por terem me ensinado a buscar, de modo incansável, as forças necessárias para tentar vencer os inúmeros obstáculos que a vida nos coloca; eles, como poucos, jamais se abateram diante de situações em que tudo indicava impossibilidade de prosseguir, e isso foi um importante ensinamento para mim. 
Agradeço ainda àqueles que, de tão próximos, não podem ser enquadrados nem junto da família, nem no rol de amigos. Eles, de fato, são uma "outra cousa". À MÁrCIA STAMATO, pela presença e pela providencial participação nas várias etapas deste mestrado, trazendo-me incentivo e fazendo com que eu acreditasse em mim, muito mais do que eu próprio; a PAUlo HenRIQUe de OliveIRA, exímio estudioso do Direito, que me prestou insubstituível ajuda na pesquisa bibliográfica e na reflexão dos pontos mais complicados e desafiadores da pesquisa realizada; a RODRIGO ISHIDA, quem me proporciona contínuas alegrias e a certeza de que São Paulo é uma das cidades mais agradáveis e fraternais que existem; à VANESSA ALVES VIEIRA, que, mais do que sua tranquila e aconchegante casa fluminense, empresta-me sempre carinho e atenção nos momentos difíceis; a SÉRGIO LONGHI e a WESLEY BORGES, meio-irmãos da querida Macaubal, que me certificam a todo tempo que uma amizade solidamente construída não pode ser abalada pela distância e nem por infindáveis compromissos profissionais.

A gratidão que tenho pelos meus amigos paulistanos (muitos deles, paulistanos "de coração”) Luma SCAFF, Túlio MASSONI, SHEIla NEDER, RobERTO CORCIOLLI, RodRigO Cipriano, Diógenes Batista, Daniela e Rafaela Tokeshi, Pedro Serrano, Mateus aranha, Dhanyel Brandẽo, Maria Heloisa Porcel, Carlos Roberto Miranda, Lucia Stamato, Venceslau Coelho, Rodrigo lage, Wallace Fernandes, Marcos Selmini, Ricardo Gutierrez, Hilonês Nepomuceno e Márcio De Meo, faz-me reconhecer que todos foram - e ainda são - os principais responsáveis pelos momentos mais marcantes que tive na maravilhosa Capital. Por isso, cabe-me, no mínimo, consignar que eles constituem partes muito significantes da minha história, e que suas respectivas amizades representam, para mim, muito mais do que podem imaginar.

Por último, não posso me esquecer dos amigos do Centro de Estudos da Administração Pública da Griffon Serviços Associados, notadamente JOAQUIM FonSECA, MÁrcio Antunes, André Rovegno e Adolpho de Paula, que me proporcionaram a tranquilidade necessária para que eu pudesse desenvolver todas as minhas atividades acadêmicas. Também registro meus irrestritos agradecimentos aos professores do Curso Clio, JoÃo DAniel de Almeida e RAPHAEla SERRADOr, os quais me permitem, cada vez mais, compartilhar com os alunos mais interessados que já conheci parte do conhecimento que adquiri nos estudos realizados ao longo desses últimos três anos, quando tive a imensa felicidade de voltar a frequentar as Arcadas do Largo de São Francisco, para a realização deste Curso de Mestrado em Direito. 


\section{SUMÁRIO}

OBSERVAÇÕES PROPEDÊUTICAS........................................................................ 1 INTRODUÇÃO ...............................................................................................

I. RELEVÂNCIA E APLICABILIDADE DO CONCEITO DE ASSIMETRIA

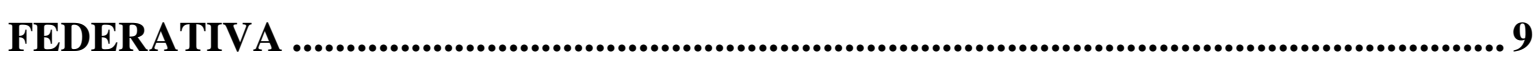

I.1. O Complicado Equilíbrio do Desigual ...................................................... 9

I.2. A Relação Simbiótica entre Direito e Política: o Caráter Bifronte da Assimetria

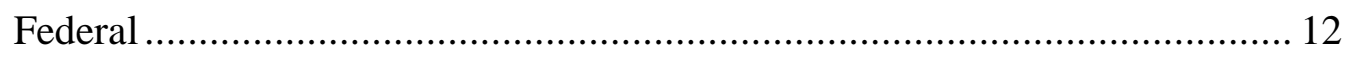

I.2.1. "Assimetrias de Fato" e "Assimetrias de Direito" ................................ 16

I.3. O Estado Federal e a Multiplicidade de Estruturas Voltadas à Acomodação dos Interesses Regionais: um Permanente Convite à Experimentação Assimétrica 18 I.3.1. "Assimetrias Estruturais" e "Assimetrias Relacionais" 25

I.4. A Ambivalência da Diversidade Regional: os Dois Caminhos Possíveis das Federações Heterogêneas ................................................................. 28

I.5. O Infundado Risco da Secessão nos Estados Federais Assimétricos.................. 38

II. EMERGÊNCIA HISTÓRICA E AFIRMAÇÃO INSTITUCIONAL DO

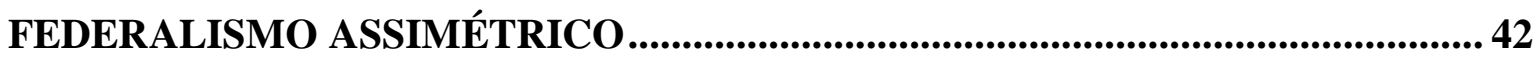

II.1. O Estado Federal no Contexto do Pós-Segunda Guerra Mundial .................. 42

II.1.1. O Estado Social e as Federações Assimétricas ................................. 46

II.1.2. A Consagração da Democracia Social e a Ascensão da Tese do Federalismo Assimétrico ............................................................... 53

II.2. A Reformulação do Pacto Federativo em Atenção aos Condicionantes do

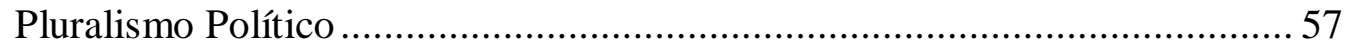

II.2.1. As Principais Técnicas de Assimetria Empregadas nos Estados Sociais

II.2.2. A Assimetria Federativa e o Contorno às Adversidades que Desestimulam a Democracia.

II.3. A Experiência Assimétrica nas Federações Contemporâneas: Apontamentos de Direito Comparado na Acomodação das Desigualdades Regionais 73

II.3.1. O Estado Federal Canadense: a Cooperação e a Coordenação como Recursos Voltados à Preservação da Diversidade. 
II.3.2. O Estado Regional da Espanha: A Heterogeneidade Materializada na Concessão de Estatutos Especiais

II.3.3. O Estado Federal Alemão: A Cooperação como Técnica de Superar Acentuadas Disparidades Econômicas

\section{A MATERIALIZAÇÃO DA ASSIMETRIA NO ESTADO FEDERAL: OS PRINCIPAIS INSTRUMENTOS DE CONCRETIZAÇÃO DOS ARRANJOS JURÍDICO-INSTITUCIONAIS DIFERENCIADORES............................................ 88}

III.1. A Igualdade como Resultado: uma Proposta para o Equilíbrio Federativo ..... 88

III.1.1. As Desigualdades Regionais e a Instauração de Preocupantes Quadros de Desarmonia Federativa

III.1.2. Transitoriedade e Excepcionalidade dos Arranjos Assimétricos ...... 100

III.2. Representação Política das Unidades Federadas e Disparidades Regionais .. 103

III.2.1. Os Impactos na Autonomia Política Decorrentes dos Desníveis Regionais

III.3. O Equilíbrio Regional e a Ininterrupta Necessidade de Adequação do Sistema de Repartição de Competências 115

III.4. Limites Constitucionais à Configuração Assimétrica do Estado Federal ...... 122

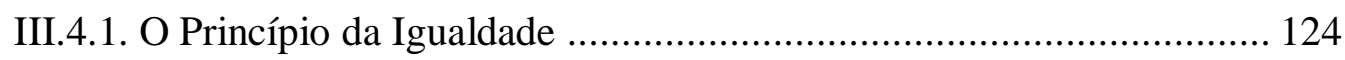

III.4.2. O Princípio da Unidade da Federação ......................................... 128

III.4.3. O Princípio da Solidariedade ................................................. 131

IV. O ESTADO FEDERAL BRASILEIRO: UM CONCERTO SIMETRICAMENTE

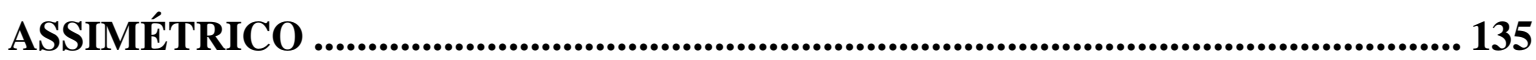

IV.1. A Federação Esculpida pelas Elites Regionais ........................................... 135

IV.1.1. Os Albores do Estado Federal Brasileiro: O Coronelismo e a Perpetuação das Desigualdades Regionais ................................... 143

IV.1.2. A Hierarquização dos Entes Federativos: A "Política dos Governadores" na Primeira República ....................................... 149

IV.1.3. A Constituição de 1934 e a Institucionalização do Federalismo Cooperativo: A Incipiente Compreensão de que as Desigualdades Regionais Constituía um Problema de Estado. 153

IV.1.4. A Negativa Reiterada da Dimensão Municipal nos Pactos Federativos Brasileiros 158 
IV.2. A Origem e o Desenvolvimento do Estado Federal no Brasil sob o Enfoque da Assimetria

IV.3. O Federalismo Assimétrico no Brasil: a Redefinição da Cooperação Federativa e o Objetivo de Reduzir as Desigualdades Sociais e Regionais no País 168

V. O ASSENTO CONSTITUCIONAL DA ASSIMETRIA NO ESTADO FEDERAL BRASILEIRO. 176

V.1. Federalismo Brasileiro e Redução das Desigualdades Regionais 176

V.2. O Predomínio das Assimetrias Relacionais na Atual Configuração da Federação Brasileira 181

V.3. Os Reflexos da Assimetria Federativa nas Previsões Encartadas na Constituição Federal de 1988 186

V.3.1. Competências Constitucionais Comuns: Estudo do parágrafo único do art. 23 da Constituição Federal

V.3.2. Regiões Metropolitanas: A Indução da Cooperação Local como Solução aos Problemas Derivados dos Serviços Comuns

V.3.3. As Regiões Administrativas: A Integração de Unidades Geográficas em Desenvolvimento 


\section{OBSERVAÇÕES PROPEDÊUTICAS}

Com o objetivo de obter-se a maior clareza possível e de proporcionar uma leitura facilitada e não cansativa ao texto confeccionado, é oportuno esclarecer que, na composição da presente dissertação, as citações literais, empregadas a partir da consulta de obras de autores estrangeiros, não traduzidas para língua portuguesa, foram vertidas para o nosso vernáculo por meio de tradução livre, pela qual assumimos total responsabilidade. Em sentido idêntico, os excertos retirados de obras nacionais pesquisadas, cuja ortografia mostrava-se arcaica, foram por nós adaptados a fim de adequarem-se às orientações ortográficas contemporâneas.

Registre-se que, na elaboração deste trabalho, foi considerado o posicionamento capitaneado por AFONSO ARINOS DE MELO FRANCO ${ }^{1}$ quanto à utilização dos termos federalismo, Federação e Estado federal, o que determina, grosso modo, os seguintes sentidos aos vocábulos referidos: "o federalismo é matéria incluída na Ciência Política; a Federação se relaciona de preferência com a Teoria do Estado, e apresenta o fato; o Estado federal diz respeito propriamente ao Direito Constitucional, e oferece a norma"2. Entretanto, em diversas oportunidades, essas expressões foram utilizadas como análogas, tendo em vista a intenção de buscar-se referenciar, em última análise, sempre o mesmo objeto de estudo, qual seja, o fenômeno federativo, entendido como mecanismo estruturante da dimensão espacial e distributiva de poder político, forma efetiva e reconhecida de organizar sistematicamente o poder nos Estados territorialmente compostos.

No que tange à redação desenvolvida, informa-se que, visando o cuidado de se proceder à delimitação de conceitos - bem como à padronização do texto -, o termo "poder central" é utilizado sempre para aludir à União, enquanto o emprego das locuções "entes periféricos" e "unidades subnacionais" guarda ligação com os Estados e os Municípios

\footnotetext{
1 A respeito da demarcação conceitual dos termos apontados ("federalismo", "Estado federal" e "Federação"), ver CeZAR SAldanha SouZa Junior, Estudo Introdutório: Em Torno do Sentido do Federalismo, in Direito do Estado - Estudos sobre Federalismo, Cezar Saldanha Souza Junior e Marta Marques Avila (coord.), Porto Alegre, Dora Luzzatto, 2007, pp. 10-12; Preston King, Federalism and Federation, Baltimore, The Johns Hopkins University Press, 1982, pp. 20-22 e 74-76; e MicHAEL BURGESS e FRANZ GRESS, Symmetry e Assymmetry Revisited, in Accommodating Diversity: Asymmetry in Federal States, Robert Agranoff (ed.), Baden-Baden, Nomos, 1999, pp. 48-53, os quais apresentam divergências de significado entre federalismo e Federação.

${ }^{2}$ Curso de Direito Constitucional, vol. I: Teoria da Constituição; as Constituições do Brasil, Rio de Janeiro, Revista Forense, 1958, p. 155.
} 
que, no país, após o advento da Constituição Federal de 1988, expressamente compõem o concerto federativo.

Cabe pontuar também que a orientação terminológica adotada consubstancia-se na premissa de que a União não goza dos poderes e das prerrogativas assentadas na noção de soberania, já que não deixa de ser um ente federado, dotado de personalidade jurídica de direito público interno. Em outras palavras, significa afirmar que, assim como os Estados e os Municípios, aquele ente federado deve ser considerado integrante da Federação, haja vista que, conforme o entendimento pacificado nas discussões da Comissão de Redação da Assembléia Nacional Constituinte de 1987-1988 (e convalidado por parcela significativa da doutrina $)^{3}$, os atributos da soberania são titularizados exclusivamente pelo Estado nacional, ou seja, pela República Federativa do Brasil.

Por último, esclarece-se que com a palavra "região" e demais expressões que façam referência aos interesses regionais - como é o caso, em especial, das expressões "diversidades territoriais" e "desníveis territoriais", utilizadas com frequência no texto pretende-se viabilizar a análise da homogeneidade espacial no planejamento regional. Buscam, em suma, retratar parcelas determinadas do território de Estados federais que apresentam características similares e, por conta disso, necessitam de cuidados e atenções também parecidos. O uso dos termos em destaque encerra duplo propósito: o primeiro, possibilitar o melhor conhecimento de um ente (ou grupo de entes) que integra o concerto federativo; o segundo, como recurso na determinação de quais esforços de

\footnotetext{
${ }^{3} \mathrm{Na} 8^{\mathrm{a}}$ Reunião Ordinária da Comissão de Redação da Assembleia Nacional Constituinte, realizada em $20 \mathrm{de}$ setembro de 1988, verificou-se o enfrentamento da questão pelos constituintes MicHEL TEMER e AFONSO ARINOS DE MELO FRANCO, os quais, contrariando o constituinte PAES LANDIM, desenvolveram ponderações no tocante à titularidade da soberania pelo Estado nacional. Acerca da questão, o primeiro assim se manifestou: [...] "soberana é a Federação como um todo, é o Estado brasileiro. As entidades políticas internas, como União, Estados, Municípios e Distrito Federal, agora, são dotadas de autonomia, que é grau inferior à soberania” (Diário da Assembleia Nacional Constituinte (Suplemento “B”), Comissão de Redação, Brasília, Senado Federal, Centro Gráfico, 1988, pp. 194-195). Em complemento, vale trazer as considerações de AFONSO ARINOS: "soberania vem do latim super omnia, quer dizer, acima de todos os outros. A ideia de soberania surgiu recentemente na história ocidental, com o aparecimento do Estado moderno. E sempre se considerou soberano o Estado em relação às entidades políticas que lhes são submetidas e que não são soberanas, estas podem ser autônomas. Portanto, acho que a palavra soberania deve aqui ser indiscutivelmente ligada ao Estado, mas não às entidades políticas internas [...]”. Em igual direção, Fernanda Dias Menezes de Almeida, Atividade Constituinte nos Estados e nos Municípios, in Revista Jurídica “9 de Julho”, no 3, 2004, p. 68; A. DE SAMPAIO DóRIA, Direito Constitucional, vol. 2: Comentários à Constituição de 1946: Arts. $1^{\circ}$ a 77, São Paulo, Max Limonad, 1960, p. 62; e CELSo BASTOS, A Federação no Brasil, Brasília, Programa Nacional de Desburocratização e Instituto dos Advogados de São Paulo, 1985 , pp. 22-23. Outros, no entanto, desconsideram a diferença entre Estado federal e União para efeitos da definição da titularidade do poder soberano, a exemplo de J. H. MEIRELLES TEIXEIRA, Curso de Direito Constitucional, Rio de Janeiro, Forense Universitária, 1991, pp. 622-627; CLÁudIO PACHECO, Tratado das Constituições Brasileiras, vol. I, Rio de Janeiro, Freitas Bastos, 1958, pp. 311-312; LENIO LUIZ STRECK e José Luiz Bolzan de Morais, Ciência Política e Teoria do Estado, $6^{a}$ ed., Porto Alegre, Livraria do Advogado, 2008, p. 171; e Raul Machado Horta, Direito Constitucional, $3^{\mathrm{a}}$ ed., Belo Horizonte, Del Rey, 2002, p. 497-498.
} 
desenvolvimento terão de ser feitos para alcançar níveis ótimos de governabilidade em relação a essas unidades autônomas apreciadas ${ }^{4}$.

${ }^{4}$ Cf. Jos G. M. Hilhorst, Planejamento Regional: Enfoque sobre Sistemas, $2^{\mathrm{a}}$ ed., Rio de Janeiro, Zahar, 1973 , p. 99. 


\section{INTRODUÇÃO}

Unidade e diversidade. À primeira vista, dois conceitos que podem parecer antagônicos se tomados abstratamente, sobretudo longe dos domínios estabelecidos pelo federalismo. No Estado federal, ao contrário, essas duas ideias se conjugam e, entrelaçadas, permitem que instituições e estruturas jurídico-políticas sejam criadas para viabilizar a governabilidade em territórios onde as diferenças entre os atores políticos exigem a elaboração de engenhos para vencer as poderosas forças desagregadoras. Mesmo em Estados em que o risco da secessão não se apresenta como provável, as heterogeneidades regionais não podem ser colocadas em plano secundário, pois os desgastes delas originados indicam a importância de jamais desconsiderá-las em qualquer organização estatal composta.

Os desníveis regionais, admitidos em seus inúmeros modos de expressão, representam a essência do regime federativo, revelando-se, indubitavelmente, como forçamotriz dos sistemas de descentralização política idealizados pelo constitucionalismo contemporâneo. Por tal razão, pode parecer desnecessário enfatizar a relevância de cuidar com expressiva atenção das disparidades que se materializam frente os entes federados, já que, por óbvio, não há Federação sem desigualdades entre as partes que a compõe. Essa aparência, entretanto, é contrariada por quadros factuais em que as heterogeneidades são tamanhas e tão drásticas que o equilíbrio, marca indelével do federalismo, dificilmente poderá ser obtido, se não forem utilizadas técnicas e instrumentos de compatibilização que, controladamente, diferenciem as unidades político-administrativas.

Como é possível perceber, a tensão e os conflitos federativos, não raro, podem exigir a formulação de mecanismos jurídicos voltados a acomodar a diversidade territorial. Esses engenhos normativos representam a essência do que se denomina federalismo assimétrico, valendo anotar que a razão de ser dos mesmos está justamente em proporcionar harmonia aos contextos que sofrem os efeitos da acentuada falta de uniformidade. Além disso, observa-se, cada vez mais, que a decisão de adotar traços assimétricos tem-se revelado de vital importância para a subsistência de algumas Federações que, antes, sofriam com a ingovernabilidade decorrente de sérios dissídios internos.

Aos arranjos jurídicos que acompanham essa vertente do Estado federal cabem, portanto, assegurar que o regime federativo obtenha o mínimo de funcionalidade em 
ambientes onde se tinha a unidade como mero recurso de retórica, pois a diversidade atuava como implacável complicador da coesão do conjunto estatal. Também se enxerga, no federalismo assimétrico, uma interessante oportunidade para o contínuo aperfeiçoamento dos laços associativos, os quais, hoje, não apenas servem para unir as partes federadas. As relações intergovernamentais assumem a condição de relevantes peças voltadas a garantir eficiência na prestação dos serviços públicos, notadamente aqueles cuja amplitude ou complexidade exigem o compartilhamento, entre os entes federados, da responsabilidade pela execução.

Dessa forma, para que possam cumprir os proeminentes propósitos que orientam sua aplicação por um número considerável de Estados, as Federações precisam estar em sintonia com as variadas bases fáticas sobre as quais serão estabelecidas. Isso significa que as infinitas estruturas jurídicas consignadas na Constituição de cada um dos países ligados ao federalismo devem retratar o compromisso do constituinte em fazer do texto constitucional um valioso instrumento de governo. Tal proposta, a despeito de ser inegavelmente coerente e adquada aos fins que regem todos os Estados, encontra fortes resistências entre os defensores dos institutos tradicionais do Estado federal, uma vez que quebra os quadrantes desenhados nas Federações do século XVIII e XIX, ao demandar a aplicação de técnicas consubstanciadas na atribuição de status diversificados aos atores integrantes do concerto federativo.

Fruto das necessidades erigidas com o advento da democracia social, o federalismo assimétrico busca reorientar a teoria do Estado federal com vistas a reduzir as problemáticas consequências provocadas pela assunção do princípio da igualdade formal como diretriz na fixação de competências constitucionais e no desempenho de cooperação intergovernamental. Empregadas com êxito em determinados Estados compostos, a exemplo do Canadá, da Espanha e da Alemanha, as assimetrias federativas se pautam, essencialmente, pelo abandono da noção de que as unidades político-administrativas devem ser isonomicamente tratadas. A inflexível paridade entre as partes federadas deixa, portanto, de ser o pressuposto organizacional de alguns Estados da atualidade, haja vista que se compreendeu a importância de dispensar o devido tratamento aos severos desníveis regionais que impedem o pleno desenvolvimento dos sistemas de descentralização política colocados em prática por várias Federações territorialmente heterogêneas.

De fato, as assimetrias têm sido responsáveis pelo aumento considerável da coesão estatal e da eficiência dos governos em países que se enquadram no cenário acima descrito, o que, obviamente, inclui o Brasil. Entre nós, embora a diversidade territorial e seus 
indesejados reflexos constituam uma constante na história do Estado brasileiro, verifica-se que, ao longo das sucessivas Constituições nacionais, não foram muitos os instrumentos idealizados para corrigir essa marcante característica de nossa Federação. A investigação dos aspectos que confirmam a adesão do sistema federativo nacional aos paradigmas veiculados pela teoria do federalismo assimétrico representa o objetivo principal deste trabalho.

De tal sorte, numa perspectiva geral, é pertinente anotar que a análise do contexto estatal brasileiro, com base nos elementos de assimetria, delimita o projeto acadêmico que norteou a elaboração da presente dissertação. Tentou-se, na medida do possível, demonstrar de que forma as desigualdades constatadas entre os entes federados são capazes de influenciar o pacto federativo, trazendo-lhe impactos estruturuais e interferindo ainda nas ações governamentais executadas. Na sequência, com o objetivo de evidenciar a configuração assimétrica do Estado brasileiro, foi empreendido o estudo dos fatores que levam à identificação de ferramentas jurídico-constitucionais habilitadas a serem alternativas viáveis para o tratamento e a superação dos obstáculos, originados na diversidade, existentes no seio de nossa organização estatal composta.

Apesar da interdisciplinaridade imanente ao tema, o enfoque foi concentrado na apreciação das alternativas colocadas pelo correto manuseio dos institutos atrelados ao Direito Constitucional. A par da relevância que se vislumbra no tocante ao ajustamento dos impasses políticos formados na ordem federativa, outra justificativa para prestigiar a aplicação do federalismo assimétrico está no aperfeiçoamento dos laços associativos que, além de garantidores da unidade dos Estados compostos, têm uma importância incontrastável para a idealização e a eficiente execução de políticas públicas. Aportadas, portanto, as coordenadas que guiaram a confecção desta dissertação, passa-se a apresentar, resumidamente, as matérias tratadas e os objetivos mirados nos cinco capítulos que a integram.

O primeiro capítulo reporta a um dos pontos mais fascinantes que acompanha os institutos relacionados com a Federação - o qual corresponde, ainda, à força-motriz que alimenta os intentos de otimizar o pacto federativo com a adoção de assimetrias jurídicas. Trata-se da delicada tarefa de obter equilíbrio nos Estados cujas severas disparidades territoriais indicam a impertinência de admitir as unidades federadas como sendo absolutamente idênticas. Também são pontuados os vários aspectos de intersecção entre Política e Direito que estão, indissociavelmente, vinculados à tese do federalismo 
assimétrico, pois objetiva-se, com isso, proceder à delimitação do campo de investigação no qual o trabalho prosseguirá nos capítulos subsequentes.

A reordenação das democracias contemporâneas após o término da Segunda Guerra Mundial serviu para desencadear a revisão de muitos conceitos historicamente firmados, dentre eles a própria disposição do regime federativo. Foi a necessidade de adaptar o Estado federal aos novos paradigmas estabelecidos nesse período que fez com que o conceito de federalismo assimétrico ganhasse projeção e entrasse definitivamente nos temas e agendas constitucionais. E é esse processo que conduziu à adoção gradativa dos instrumentos de diferenciação federativa que constitui o assunto desenvolvido no segundo capítulo da dissertação.

Ainda no âmbito do capítulo segundo, são apresentadas algumas referências fundadas em estudos comparatísticos de Direito. Tomam-se as experiências das Federações canadense e alemã, além do Estado regional espanhol, como modelos para verificar prováveis pontos de interesse para o incremento dos índices de coesão federativa e dos níveis de eficiência governamental apurados no Estado brasileiro. Mais do que descrever o funcionamento dos mencionados regimes político-constitucionais, pretendeu-se certificar, em atenção às características definidoras do federalismo pátrio, quais aparatos estrangeiros poderiam ser aproveitados entre nós para a obtenção dos propósitos aludidos.

O capítulo de número três aborda os mais exemplificativos institutos jurídicos de concretização das assimetrias no interior das Federações. Nessa parte do trabalho, é assinalada a ampla significância que o princípio da igualdade material, aplicado em face dos integrantes da organização estatal, adquire para a elaboração de ferramentas voltadas a combater as forças desagregadoras que decorrem de quadros reais de marcantes desníveis regionais. Ao final, são colocados os limites constitucionais que deverão ser seguidos pelos Estados que optarem por fazer do federalismo assimétrico um de seus vetores de conformação estrutural.

O penúltimo capítulo (capítulo quatro) fornece uma síntese histórica da gama de fatores que contribuíram para a definição dos mais conhecidos atributos particularizantes do Estado nacional. Do acordo político entre as elites regionais no final dos tempos imperiais à proclamação da Constituição Federal de 1988, procura-se esclarecer os aspectos de maior envergadura no acirramento dos conflitos federativos observados ao longo do trajeto histórico-institucional pelo qual a Federação foi submetida. Grife-se, por oportuno, que os esforços despendidos nesse bloco da dissertação estiveram lastreados na convicção de que seria impossível compreender as atuais variantes que interferem na 
ordenação do Estado federal, sem o mapeamento das etapas de evolução e de retrocesso suportadas pelo pacto responsável por sustentar todas as estruturas federativas.

Por derradeiro, o capítulo cinco é dedicado a explicitar as assimetrias jurídicas previstas no texto da Constituição em vigor. Analisam-se, em suma, os possíveis modos de empregá-las, sem que haja excessos ou deturpações dos valores que informam o universo do federalismo assimétrico. Cumpre informar ainda que a alocação desse capítulo na última parte do trabalho ocorreu porque se acreditou no fato de que, depois de terem sido analisadas as ideias teóricas do federalismo assimétrico nos capítulos anteriores, bem como já se conhecerem os mais complicados pontos de tensão federativa do Estado brasileiro, ficaria mais fácil entender a sistemática que disciplina o emprego dos arranjos que pretendem acomodar as heterogeneidades regionais.

Assim sendo, apenas mais uma observação precisa ser feita: a de que, como ficará comprovado ao longo da argumentação apresentada, a feição assimétrica tomada por qualquer Federação refletirá um caráter nitidamente dinâmico das estruturas políticas e administrativas do Estado. Esse detalhe traduz-se em peça crucial para a compreensão de que os tradicionais contornos institucionais do federalismo devem ceder espaço para que novas técnicas de arquitetura estatal possam adaptar o Estado federal aos impostergáveis reclamos que lhe são impostos nos dias de hoje. Sem dúvida, o federalismo assimétrico dispõe-se como a mais difundida proposta para cumprir essa imprescindível função. 


\section{RELEVÂNCIA E APLICABILIDADE DO CONCEITO DE ASSIMETRIA FEDERATIVA}

\begin{abstract}
“A arte da condução dos negócios públicos não está apenas no trato de todos os conflitos, no âmbito de uma sociedade, mas na criação de estruturas que permitam a conciliação das divergências que vão surgindo no correr do tempo".
\end{abstract}

JOSÉ ALFREDO DE OLIVEIRA BARACHO ${ }^{5}$

\section{I.1. O Complicado Equilíbrio do Desigual}

O estudo e a satisfatória compreensão do fenômeno constitucional da assimetria, na configuração do Estado federal, não representam tarefas das mais fáceis de serem empreendidas no campo do Direito Constitucional. Ao contrário, constituem missão árdua, muitas vezes carecedora de certezas, cujo resultado nem sempre se faz refletir na tradução adequada e fiel dos postulados jurídicos que conduzem à identificação e à qualificação do federalismo nos moldes propugnados pelas teorias tradicionalmente avalizadas. A complexidade cingida ao tema é tamanha que JAVIER GARCíA ROCA adverte ser a tese do federalismo assimétrico suscitadora de "numerosas incógnitas para poder ser aceita pacificamente pelo Direito Constitucional”, , de forma que não se pode adotá-la nem empregá-la adequadamente sem antes realizar aprofundada análise dos elementos que a circundam.

Desvendar, ao menos em parte, os mais alentados pontos que impregnam a característica da assimetria a uma determinada unidade estatal reclama a convergência das atenções a múltiplos e intrincados fatores de conformação estrutural que permeiam as instituições políticas de cada Estado. Essa necessidade, inelutavelmente, acaba conduzindo o debate para o enfrentamento das grandes questões correlatas à revisão conceitual e prática das bases que conferem sustentação aos Estados concretamente construídos e subsistentes na atualidade. Independentemente dos contrastantes condicionamentos históricos, geográficos, econômicos, sociais e culturais, ligados de modo visceral à gênese

\footnotetext{
${ }^{5}$ Federalismo Simétrico e Federalismo Assimétrico. O Ajuste da Distribuição de Competências e de Recursos entre União, Estados e Municípios em Face de Vicissitudes de um Estado Moderno, in 10 anos de Constituição, IBDC (Instituto Brasileiro de Direito Constitucional) (coord.), São Paulo, Celso Bastos Editor, 1998, p. 58.

${ }^{6}$ España Asimétrica (Descentralización Territorial y Asimetrías Autonómicas: una Especulación Teórica), in Asimetría y Cohesión en el Estado Autonómico: Jornadas sobre el Estado Autonómico: Integración y Eficacia, INAP (Instituto Nacional de Administración Pública), Madrid, Ministerio de Administraciones Públicas, 1997, p. 59.
} 
e ao desenvolvimento de cada uma das organizações estatais, mostra-se pertinente proceder a essa investigação com base nos paradigmas estabelecidos pelo sistema federativo de divisão espacial e de compartilhamento do poder político ${ }^{7}$. Isso porque cabe às ferramentas plasmadas no texto constitucional servir de instrumento para a materialização do federalismo assimétrico.

Em que pesem as impressões positivas extraídas do relativo sucesso dos modelos assimétricos de federalismo já experimentados e a profusão de estudos científicos nos últimos anos que procuram apreciar, sob o prisma da dogmática constitucional, esse tema, a precisa delimitação do conceito de assimetria e as decisões de quando e com qual extensão empregá-lo continuam representando complicados desafios aos governantes e aos órgãos de poder encarregados de ordenar a vida social e política em Estados compostos ${ }^{8}$, onde são encontradas múltiplas disparidades entre as partes do todo.

Ganha destaque a orientação de que os eventuais pontos de tensão prejudiciais à higidez do conjunto, originados diretamente da heterogeneidade territorial vivenciada pelos Estados, devem ser submetidos ao domínio de complexos recursos de engenharia constitucional $^{9}$ voltados a promover a efetiva acomodação dessas diferenças. O federalismo assimétrico dispõe-se, assim, como ferramenta viável para que se construa o complicado equilíbrio do desigual, conforme sintetiza conclusivamente FRANCISCO CAAMAÑO, o que implica ainda, em certa medida, "uma arquitetura de risco (hi-tech), na

\footnotetext{
${ }^{7}$ A importância do Estado federal para o constitucionalismo contemporâneo pode ser ilustrada pelas conclusões tiradas por RONAL L. WATTS, após minucioso estudo comparatístico. Nesse trabalho, foi estimado que, no último decênio do século XX, entre os aproximadamente 180 Estados soberanos existentes, a título exemplificativo, somente 24 deles eram Federações que atingiam diretamente a vida de 2 bilhões de pessoas - ou seja, cerca de $40 \%$ da população do mundo -, números que, apesar de serem expressivos, são incapazes de esgotar o interesse no tema, sobretudo quando se considera que muitos outros Estados federais, geralmente erigidos em pequenas faixas territoriais e com populações menos numerosas, foram exitosos em criar, por meio da manipulação dos instrumentos arraigados ao regime federativo, soluções para problemas de compatibilização de diversidades acentuadas que, em tese, indicariam a impossibilidade de forjar-se um efetivo e permanente pacto federativo, Cf. Comparing Federal Systems, $2^{\mathrm{a}}$ ed., Ontario, Institute of Intergovernmental Relations, 1999, p. 4.

${ }^{8}$ A natureza composta de um Estado, de acordo com a definição de ANDERSON DE MENEZES é adquirida, em linhas gerais, pela constatação do fato de ser a organização estatal formada por meio da congregação de outros Estados que acabam sendo abrangidos, de forma que se vislumbre "um verdadeiro Estado de Estados, com duas ou mais fontes de elaboração do Direito e igual número de esferas para sua validade", cabendo registrar ainda que, na contemporaneidade, o Estado federal é realçado como manifestação indubitável e mais representativa desse tipo de Estado (Cf. Teoria Geral do Estado, $8^{\text {a }}$ ed., Rio de Janeiro, Forense, 1999, pp. 187-188). Ainda sobre essa definição - e com vistas à apreciação da assimetria nos Estados territorialmente compostos -, Desiderio Fernández MANJón, La Colaboración en el Estado Compuesto Asimétrico: El Caso de España, Oñati, IVAP, 2001, pp. 35-36.

${ }^{9}$ No que tange à delimitação conceitual de engenharia constitucional, ver GIOVANNI SARTORI, La Ingeniería Constitucional y sus Limites, in Teoría y Realidad Constitucional, $\mathrm{n}^{\circ}$ 3, 1999, pp. 80-81 e José ALFREDO OLIVEIRA BARACHO, Reengenharia do Estado (Aula inaugural pronunciada na abertura do ano letivo de 1995, $2^{\circ}$ semestre, nos cursos de Pós-Graduação em Direito da Universidade Gama Filho), Rio de Janeiro, Ed. Gamma, 1995, p. 10.
} 
qual a elasticidade dos seus instrumentos compensa, num delicado equilíbrio, a permanente ameaça de desmoronamento" 10 .

Ligadas à questão da assimetria - e, por conseguinte, ao balanceamento do poder nas Federações - estão outras matérias de complexa intelecção, cujos reflexos ultrapassam a discussão acerca da compatibilização das diferenças materializadas entre as unidades federadas. Conjugam-se ao federalismo assimétrico temas desafiadores e ainda insolúveis, como é o caso, por exemplo, da discussão acerca dos impactos (potenciais e concretos) da indiferença de alguns governantes em efetivar da igualdade política entre seus cidadãos; das consequências advindas da assunção de uma posição de neutralidade cultural pelo Estado (sobretudo naqueles onde há patentes divergências socioculturais); dos conflitos ocasionados pela solidificação de grupos nacionalistas em Estados que deixam de atender a contento os reclamos das minorias; dos choques engendrados ao constitucionalismo em decorrência da progressiva tomada de consciência a respeito da necessidade de o poder estatal atuar como agente garantidor da preservação da diversidade; dos impactos causados às estruturas políticas em virtude da implementação de alguns direitos sociais que tomaram dimensões coletivas; e ainda, por decorrência invariável, das multifacetadas formas desenhadas para potencializar o processo de adaptação do federalismo a um mundo muito mais complexo e inconstante do que aquele em que originalmente foi concebido ${ }^{11}$.

Considerado esse enredado panorama em que as diferenças territoriais demandam mecanismos conciliadores do antagonismo de interesses capitaneados pelas partes do conjunto federativo, é fundamental que se analise o federalismo assimétrico com base na perspectiva assinalada por PABLO A. RAMELLA, no sentido de que "as teorizações políticas são boas sempre que vêm acompanhadas de soluções concretas para os problemas concretos" $" 12$. Com efeito, a observância dessa diretriz tende a garantir que o federalismo busque, de modo permanente, alcançar o objetivo de conceber instrumentos políticos e jurídicos amplamente exequíveis no plano da realidade. Assim é que se pretende identificar os principais fatores que interagiram - e que ainda permanecem importantes - na configuração do Estado federal no país, aqueles pontos que, além de possibilitar a ocorrência da descentralização política, determinaram também o surgimento de elementos desencadeadores da assimetria.

\footnotetext{
10 “Federalismo Assimétrico": La Impossible Renuncia al Equilibrio, Ob. cit., p. 363.

${ }^{11}$ Cf. EnRIC Fossas e FERRAn ReQuejo, Intoducción, in Asimetría Federal y Estado Plurinacional: El Debate sobre la Acomodación de la Diversidad en Canadá, Bélgica y España, Enric Fossas e Ferran Requejo (eds.), Madrid, Trotta, 1999, p. 20.

${ }^{12}$ Replanteo del Federalismo, Buenos Aires, Depalma, 1971, p. 50.
} 


\section{I.2. A Relação Simbiótica entre Direito e Política: o Caráter Bifronte da Assimetria Federal}

A assimetria enraizada em uma Federação é acolhida como sendo o predicado identificador de "desigualdade, desuniformidade e desproporção" "13 na disposição constitucional dos entes federados ou ainda na caracterização das relações intergovernamentais travadas por eles. Subjacente ao conceito de regime federativo sempre estará a difícil tarefa de compor os interesses conflitantes no terreno da descentralização espacial do poder político dos Estados compostos. De fato, essa problemática tarefa acaba impregnando natureza bifronte aos sistemas federalistas existentes, pois, conforme sentencia KONRAD HESSE, "não se pode compreender a verdadeira natureza federal de um Estado valendo-se apenas de construções estritamente jurídicas" ${ }^{14}$.

No Estado Federal elevam-se em importância as ligações de complementaridade que inegavelmente existem entre a Ciência Política e o Direito Constitucional ${ }^{15}$, e, com maior razão, a referida relação acentua-se sobremaneira no universo das assimetrias federativas. Essa manifestação simbiótica exige das autoridades competentes para a criação do Direito o indispensável conhecimento da realidade política, sem o qual jamais será possível a elaboração de normas dotadas de juridicidade e exitosas em disciplinar, sem artificialismos, as aspirações externadas no quadro político-social para o qual se legisla ${ }^{16}$.

A elaboração do Direito positivo está, assim, predestinada a responder às manifestações econômicas e sociais do universo da governança, e o constitucionalismo não pode se esquivar de cumprir essa recomendação, sob pena de se elaborarem textos jurídicos totalmente inócuos e vazios de aplicabilidade. Nessa direção, PINTO FERREIRA chama a atenção para o fato de "as Constituições não se apresentam como formas puramente espirituais, esculturadas pela razão pura, tais quais obras da imaginação. Ao contrário, se bosquejam como um traslado, um decalque ou um reflexo do meio social, histórico e cultural"17.

\footnotetext{
${ }^{13}$ Esther Seijas Villadangos, Configuración Asimétrica del Sistema de Comunidades Autónomas, vol. 1, Léon, Universidad de Léon, Secretariado de Publicaciones y Medios Audiovisuales, 2003, p. 255.

${ }^{14}$ El Estado Federal Unitario, in Revista de Derecho Constitucional Europeo, no 6, jul./dic. 2006, p. 429.

${ }^{15}$ Cf. Klaus Schubert, Federalismo. Entre Política y Ciencia, in Revista de Estudios Políticos, no 96, 1997, p. 164.

${ }^{16}$ Cf. J. H. MeIRelles TeIXeIRA, Ob. cit., pp. 18-19.

${ }^{17}$ Princípios Gerais do Direito Constitucional Moderno, tomo I, $2^{\mathrm{a}}$ ed., Rio de Janeiro, José Konfino, 1954, p. 47.
} 
Feitas essas considerações, não é despropositado estendê-las à teoria do federalismo, evitando, desse modo, que se proceda ao desenvolvimento de instituições ou construções organizacionais ineficientes e desajustadas, incapazes de atender as necessidades que lhes serão colocadas pela dimensão factual do Estado. Defende DIETER GRIMM que a criação do Direito transformou-se em um genuíno processo decisionista ${ }^{18}$, sendo hoje uma escolha humana, tomada conscientemente no plano político. A Constituição significa, portanto, consoante conhecida construção de CARL SCHMITT, a materialização de um ato decisório conjuntural e cujo objetivo primeiro é o de disciplinar o modo acertado para a consecução da unidade política estatal ${ }^{19}$.

$\mathrm{O}$ certo é que as interações entre os fatores jurídicos e políticos motivam, em absoluto, as decisões dos órgãos estatais no momento de criação das normas jurídicas ${ }^{20}$. De fato, a compreensão das disposições sociais e de toda a ordem de questões que incidem sobre a vigência da norma constitucional é imprescindível para que seus efeitos e sua eficácia possam ser delimitados de forma satisfatória. Por isso, assinala FRANCISCO FERNÁNDEZ SEGADO que é censurável - sobretudo na definição da forma de Estado traduzida juridicamente na Constituição - entender a criação do Direito por meio da imagem do jurista confinado apenas ao recinto normativo, distante, portanto, da realidade e das demais forças que imperam no meio social ${ }^{21}$.

Nesse compasso, como é sabido que o elemento garantidor da sustentação jurídica da Federação será "sempre uma Constituição comum a todas as entidades federadas, na qual estão fixados os fundamentos essenciais de suas relações recíprocas"22, a observância do postulado da indissociabilidade entre Direito e Política ganha especial significado para a arquitetura do regime federativo. Caberá, pois, ao poder encarregado de inaugurar o Estado prestar firme compromisso de investigar, demarcar e observar de forma fiel e ajustada os "fatores reais de poder",23, não podendo prescindir, nessa empreitada, do conhecimento

${ }^{18}$ Cf. Constituição e Política, Belo Horizonte, Del Rey, 2006, p. 3.

${ }^{19}$ Cf. Teoria de la Constituición, Madrid, Revista de Derecho Privado, s/d, p. 23.

${ }^{20}$ Cf. Miguel Reale, Lições Preliminares de Direito, $27^{\mathrm{a}}$ ed., São Paulo, Saraiva, 2009, pp. 331-332.

${ }^{21}$ Cf. La Dimensión Axiológica del Derecho Constitucional, in Cuadernos Constitucionales de la Cátedra Fadrique Furió Ceriol, $\mathrm{n}^{\mathrm{o}}$ 1, 1992, p. 20. Sobre esse ponto, verificar também NORBERTO BOBBIO, Da Estrutura à Função: Novos Estudos de Teoria do Direito, Barueri, Manole, 2007, pp. 47-49; e PONTES DE Miranda, Comentários à Constituição da República dos E. U. do Brasil, tomo I, artigos 1-103, Rio de Janeiro, Guanabara, 1936, pp. 88-89.

${ }^{22}$ Fernanda Dias Menezes de Almeida, Competências na Constituição de 1988, 4ª ed.;São Paulo, Atlas, 2007, p. 12.

${ }^{23}$ FERDINAND LASSALLE pontifica que "os problemas constitucionais não são problemas de direito, mas do poder; a verdadeira Constituição de um país somente tem por base os fatores reais e efetivos do poder que naquele país regem, e as Constituições escritas não têm valor nem são duráveis a não ser que exprimam fielmente os fatores do poder que imperam na realidade social: eis aí os critérios fundamentais que devemos 
empírico proporcionado pela Ciência Política. Trilhar sentido oposto a essa orientação certamente ensejará o surgimento, em intensidades variáveis, do fenômeno denominado por AFONSO ARINOS DE MELO FRANCO de patologia constitucional, correspondente ao "aparecimento das Constituições-mito, ineficazes, inaplicáveis, que geram o desencanto dos escritores de Direito Público" ${ }^{24}$.

Assim é que todo o projeto político de Estado descentralizado que - a par da diversidade territorial naturalmente encontrada - obtenha sucesso na instauração de uma homogeneidade política gravada nas disposições constitucionais e que, concomitantemente, consiga assegurar a preservação da diversidade econômica e social tende a ser aceito como esboço de Federação viável. Afinal, o pressuposto de todo regime federativo é permitir que as partes se completem no todo nacional, de forma que a soma dos valores comungados pelos componentes do conjunto traduza-se em comandos informadores das verídicas exigências e expectativas que motivaram a criação da organização estatal.

Não se pode aceitar sem reservas a diretriz que propugna ser a Constituição a encarnação tão-somente de uma lei de caráter superior, uma vez que o substrato do texto constitucional precisa retratar fielmente os aspectos geográficos, históricos e sociais que atribuem ao Estado fisionomia orgânica. Deve, pois, transmutar-se em uma obra adequada aos contextos territoriais que se propõe a organizar e a conferir sistematização, especialmente quando as atenções estão focadas na construção de um Estado composto coeso, equilibrado e totalmente calibrado face ao ambiente plural no qual geralmente estará inserido.

No quadro institucional do federalismo, é perceptível a nítida influência que as orientações empíricas e comparatísticas exercem sobre as recentes teorias voltadas à análise do fenômeno federativo. Esse fator repercute abertamente na consideração de variantes de índole política que margeiam os debates teóricos formulados a respeito da

sempre lembrar" (Que é uma Constituição?, Porto Alegre, Villa Martha, 1980, p. 73). Sufragam esse posicionamento: VICTOR Nunes LeAl, Poder Constituinte, in Revista Forense Comemorativa - 100 anos, vol. 1, Nagib Slaibi Filho (coord.), Rio de Janeiro, Forense, 2005, p. 174; CARLOS AYRES BritTo, Teoria da Constituição, Rio de Janeiro, Forense, 2003, p. 39; CARlos Roberto Pellegrino, Compromisso Constituinte, in Revista de Informação Legislativa, Brasília, ano 24, no 96, out./dez. 1987, p. 40; PABLO LuCAS VERdú, O Sentimento Constitucional: Aproximação ao Estudo do Sentir Constitucional como Modo de Integração Política, Rio de Janeiro, Forense, 2004 , p. 70; MANOEL DE Oliveira Franco Sobrinho, Regimes Políticos: Subsídios para Processo de Reorganização Política Nacional. Uma Constituição para o Brasil, Rio de Janeiro, Forense, 1984, p. 107; MANOEl GonÇAlves FERreIRA Filho, O Poder Constituinte, $3^{a}$ ed., São Paulo, Saraiva, 1999, p. 22; Dalmo DE ABreu DAllari, Constituição e Constituinte, $3^{\mathrm{a}}$ ed., São Paulo, Saraiva, 1986, pp. 17-18, entre outros.

${ }^{24}$ Ob. cit., p. 118. 
matéria. Ademais, a idealização de Estados federais com o intuito de promover muito mais do que a mera descentralização política, transformando-os em prometida ferramenta de mudança (ou, conforme o caso, de apaziguamento) social em países onde há acentuada heterogeneidade interna, recomenda a definição, no corpo das normas constitucionais, de questões e agitações políticas que terão de ser conciliadas com a divisão espacial do poder. Verifica-se, assim, a formação de um frutífero diálogo entre as dimensões jurídicas e políticas do regime federativo, beneficiando-se reciprocamente tanto a Ciência Política e as demais Ciências Sociais quanto o Direito Constitucional ${ }^{25}$.

Consente-se, pois, que, naqueles contextos de marcantes desigualdades factuais, a Federação arquitetada deverá contar com eficientes recursos jurídicos prontos para compatibilizar disparidades sociais, históricas, culturais, políticas, econômicas e étnicas, porventura existentes. Os aspectos de inflexão e de ameaça à subsistência do pacto federativo, bem como os prováveis fatores que dificultarão o desenvolvimento do conjunto, terão de receber a devida atenção no texto jurídico confeccionado pelo constituinte. Do contrário, haverá desrespeito ao padrão lógico e mais básico em matéria de criação de instituições políticas: a adequação à realidade sobre a qual os órgãos políticos do poder pretendem atuar.

A contrariedade a esse comando diretivo provavelmente redundará, em última análise, no fracasso de todo projeto político de Estado que venha a ser aventado, mesmo havendo inquestionável excelência teórica e rigor científico a permear as disposições legais produzidas. Não há como ser diferente, pois somente o sistema federativo que atender cabalmente aos reclamos de acomodação da diversidade própria a cada um dos entes que a compõem é que "terá toda a probabilidade de ser o melhor em todos os sentidos, uma vez que é dessas qualidades, na proporção em que se respeita as assimetrias naturais existentes dentre as unidades federadas, que depende a eficácia das ações governamentais em suas operações práticas",26.

Mensurar o grau de engajamento das unidades federadas e do poder central em relação ao Estado federal é sempre problemático, haja vista que "o sucesso dos sistemas federais não se caracteriza somente por seus arranjos constitucionais, mas pela sua penetração no espírito federalista" ${ }^{27}$, e não há nenhuma fórmula estabelecida para perceber

\footnotetext{
${ }^{25}$ Cf. RAMÓn MÁIZ SuÁrez, Federalismo Plurinacional: Una Teoria Política Normativa, in Revista d'Estudis Autonòmics i Federals, no 3, 2006, pp. 45-46.

${ }^{26}$ Augusto Zimmermann, Teoria Geral do Federalismo Democrático, $2^{\mathrm{a}}$ ed., Rio de Janeiro, Lumen Juris, p. 64.

${ }^{27}$ Dircêo Torrecillas Ramos, O Federalismo Assimétrico, $2^{\mathrm{a}}$ ed., São Paulo, Forense, 2000, p. 36.
} 
o quão arraigado está esse espírito nas partes do conjunto. O que se sabe é que o absoluto descuido das próprias disparidades territoriais não é o caminho para que um Estado federalizado alcance a solidificação e o aperfeiçoamento de seu pacto federativo. A insatisfação dos atores federativos, quando extremada, impede o encontro de equilíbrio entre pluralidade e unidade ${ }^{28}$, e, quando isso ocorre, a Federação autêntica deixa de existir, porque não se farão presentes e operantes, conforme estatui ALEXIS DE TOCQUEVILLE, "as vantagens que os povos tiram da grandeza e da pequenez de seu território"29.

\section{I.2.1. "Assimetrias de Fato" e "Assimetrias de Direito"}

Essa interdependência estabelecida entre Direito e Ciência Política figura como característica indissociável do federalismo assimétrico. É ela a responsável pela classificação mais conhecida empregada pela doutrina a respeito das assimetrias: os conceitos de "assimetria de fato" e de "assimetria de direito",30, ambos correspondentes a maneiras específicas de materialização do fenômeno assimétrico. Valida essa constatação DIRCÊO TORRECILLAS RAMOS, ao enfatizar que "enquanto que para o cientista político o impacto da primeira sobre o sistema federal é uma importante área para a análise, para aqueles envolvidos na elaboração da Constituição ou seus ajustes, a questão básica é se a própria Constituição deveria de jure tratar as várias unidades constituintes diferentemente e quais os seus efeitos prováveis da aplicação dessa assimetria" ${ }^{31}$.

Entrevê-se, na afirmação aposta acima, que é perfeitamente factível se enxergar a assimetria mediante duas perspectivas diversas: a ofertada pela visão jurídica e a referente ao ângulo político. Cada qual possui métodos próprios de análises e mecanismos diferentes de tratamento da questão da diversidade agasalhada pelas Federações. Todavia, deve-se concordar que a identificação, feita pelo cientista político, de disparidades entre as peças integrantes do conjunto federativo é o primeiro passo para que esquemas racionais de

\footnotetext{
${ }^{28}$ Cf. José AlFREDO DE Oliveira BARACHO ensina que a estrutura do Estado federal, apesar das diferenças concretas que ocorrem através dos diversos modelos que surgem, apresenta alguns pontos comuns, figurando certamente, dentre eles, a necessária consecução do equilíbrio da pluralidade com a unidade, Teoria Geral do Federalismo, Belo Horizonte, FUMARC/UCMG, 1982, p. 24.

${ }^{29}$ A Democracia na América, Livro 1: Leis e Costumes, São Paulo, Martins Fontes, 2005, p. 178.

${ }^{30}$ Cite-se, a título de exemplo, os estudos feitos por Ronald L. WatTs, Comparing Federal Systems, Ob. cit., p. 63; ROBERT Agranoff, Power Shifts, Diversity and Asymmetry, in Accommodating Diversity: Asymmetry in Federal States, Robert Agranoff (ed.), Ob. cit., pp. 16-17; Michael Buguess E Franz Gress, Symmetry and Asymmetry Revisited, in Accommodating Diversity: Asymmetry in Federal States, Robert Agranoff (ed.), Ob. cit., pp. 50-54.

${ }^{31}$ O Federalismo Assimétrico, Ob. cit., p. 65.
} 
compatibilização dessas desigualdades venham a ser consagrados nas normas constitucionais produzidas.

Cabe esclarecer, nessa altura, que a primeira espécie de disposição assimétrica está presente em todos os Estados federais do mundo, recebendo a rubrica de "assimetria de fato" ou "assimetria política" 32 . Sua conformação está relacionada com a existência de impactantes desníveis em matérias culturais, históricas, econômicas, geográficas, políticas e sociais, em patamares suficientes para provocar a perceptível diferenciação de cada uma das unidades federadas, ainda que essas gozem do mesmo enquadramento jurídico. Essas diferenças estruturais, quando muito acentuadas, conduzem à realização de relações intergovernamentais inconstantes e desiguais entre os próprios entes federados, bem como no que respeita aos contatos decorrentes de duradoutras ou esporádicas relações estabelecidas pelas diversas partes autonômicas com o poder central.

O outro tipo de manifestação do federalismo assimétrico, rotulado de "assimetria constitucional", "assimetria de direito" ou "assimetria juris", nem sempre será observado nas Federações. Há sistemas federais que não o utilizam, porque seu emprego depende de expressa consagração nas respectivas Constituições. Essa espécie de assimetria repousa, no geral, em fórmulas diferenciadas de distribuição de competências entre entes federados, além de serem albergadas em múltiplas alternativas de compatibilização das heterogeneidades regionais por meio de arranjos constitucionais encarregados de definir a feição de cada um dos Estados federais existentes ${ }^{33}$.

As "assimetrias de fato" são, portanto, as verdadeiras condicionantes da empregabilidade das "assimetrias de direito" "34 Impossível, por força dessa verificação, deixar de concluir a forte influência impregnada pelas determinantes políticas à conformação jurídica e estrutural conferida às Federações. Daí o porquê MiCHAEL BURGESS admite que a teoria do federalismo assimétrico despertou, em definitivo, a atenção dos teóricos para "a anatomia do sistema federativo em toda sua complexidade"35, fazendo com que se considerasse verdadeiramente a gama de aspectos de diferenciação que atinge os entes federados, incluindo-se também nesse rol as relações intergovernamentais praticadas por eles.

\footnotetext{
${ }^{32}$ Em abono, DAVID MILNE grifa que "não há nenhuma Federação em que as unidades sejam simétricas: variam quanto ao tamanho, forma, economia, geografia, população, riqueza, quando não são diversas por sua cultura ou história”, Igualdad o Asimetría: ¿Por qué Elegir?, in Asimetría Federal y Estado Plurinacional: El Debate sobre la Acomodación de la Diversidad en Canadá, Bélgica y España, Enric Fossas e Ferran Requejo (eds.), Ob. cit., p. 71.

${ }^{33}$ Cf. Ronald L. Watts, Comparing Federal Systems, Ob. cit., p. 63.

${ }^{34}$ Cf. Dircêo Torrecillas Ramos, O Federalismo Assimétrico, Ob. cit., p. 60.

${ }^{35}$ Comparative Federalism: Theory and Practice, London, Routledge, 2006, p. 211.
} 
A conclusão segura a que se chega é a de que a desatenção aos pontos de tensão derivados da diversidade territorial levará invariavelmente à construção de Estados contaminados pelo artificialismo e, por conseguinte, pouco funcionais. Negligenciar os desníveis que tomam conta das regiões congregadas pelo laço federativo pode, de fato, acarretar a criação de Federações desprovidas de níveis mínimos de legitimidade ${ }^{36}$, sobretudo ao se considerar o registro de RICARDO LOBO TORRES, na perspectiva de que somente estarão adequados aos padrões entendidos como legítimos os ajustes constitucionais de poder que, além de cumprirem os requisitos elementares de validade e de existência, busquem incessantemente, nas demandas reais da sociedade a que servem, sua indeclinável razão de $\operatorname{ser}^{37}$.

\section{I.3. O Estado Federal e a Multiplicidade de Estruturas Voltadas à Acomodação dos} Interesses Regionais: um Permanente Convite à Experimentação Assimétrica

O federalismo, entendido por alguns como uma espécie de analogia vertical do dogma da separação de poderes elaborado por MONTESQUIEU ${ }^{38}$, vem sendo exitosamente utilizado para organizar Estados onde se verificam variadas condições socioeconômicas, geopolíticas e culturais; múltiplas necessidades regionais - algumas aparentemente inconciliáveis -; além de marcantes peculiaridades históricas. Esses fatores, conjugados ou não, ao serem considerados em sua dimensão estrutural, apontam para o imperativo de adotar-se um sistema operacional de ordenação territorial cujo traço proeminente reside, em essência, na institucionalização de relações recíprocas de poder entre os participantes da unidade estatal, com vistas a modelar uma permanente e salutar rede de relacionamentos cooperativos.

O desafio maior que se coloca a qualquer Federação é o de, não obstante a força desagregadora de inúmeros elementos desafiadores da sedimentação de um pacto duradouro, fazer com que o arcabouço jurídico desenhado no texto constitucional consiga

\footnotetext{
${ }^{36}$ A respeito da delimitação do conceito de legitimidade recorrer a JOSÉ EDUARDo CAMPOS DE OLIVEIRA FARIA, Legalidade e Legitimidade: A Reordenação Institucional do País, in Revista de Direito Constitucional e Ciência Política, ano 3, nº 4, jan./jun. de 1985, pp. 48-59; e de RAYMUNDO FAORO, Assembléia Constituinte: A Legitimidade Recuperada, $5^{\text {a }}$ ed., São Paulo, Brasiliense, 1986, pp. 43-55.

37 Cf. O Princípio da Transparência no Direito Financeiro, in Revista de Direito da Associação dos Procuradores do Novo Estado do Rio de Janeiro, Rio de Janeiro, Lumen Juris, 2001, pp. 133-134.

${ }^{38}$ Nesse sentido: Celso Bastos, A Federação no Brasil, Ob. cit., p. 4; KlAUS SCHUBERT, Ob. cit., p. 166; Peter HäBerle, Comparacíon Constitucional y Cultural de los Modelos Federales, in Revista de Derecho Constitucional Europeo, $\mathrm{n}^{\circ}$ 8, jul./dic. 2007, p. 178; e MARCELO DUARTE, Justiça Social e Federação (Tese $\left.n^{o} 33\right)$, in $9^{a}$ Conferência Nacional da Ordem dos Advogados do Brasil, Florianópolis, 1982, p. 8.
} 
integrar as diversas ordens governamentais na execução de um único projeto nacional de desenvolvimento $^{39}$. A proposição teórica do federalismo assimétrico, consoante anota seu idealizador, CHARLES D. TARLTON, é justamente a de permitir aos construtores de regimes federativos a possibilidade de afirar a viabilidade das estruturas jurídico-políticas criadas mediante a análise dos laços associativos estabelecidos. Assim, todo Estado federal somente poderá subsistir em níveis ótimos de harmonia se os elementos de similitude entre os componentes do sistema predominarem sobre os aspectos de diversificação presentes ${ }^{40}$.

A compreensão dos mecanismos de interação estabelecidos entre os entes assume posto de destaque na construção e na consolidação do regime federativo, uma vez que caberá a esse entrelaçamento de contatos o encargo de manter a coesão e a funcionalidade da Federação, além de permitir o aperfeiçoamento constante das instituições políticas do Estado. Deve-se, portanto, realizar um satisfatório mapeamento das diferenças naturalmente existentes no cenário de instalação do Estado federal para que se encontre fórmula jurídica habilitada a garantir a adequada correlação da divisão vertical do poder político com os elementos dissonantes mais gravosos à sobrevivência do próprio pacto federativo $^{41}$.

De tal modo, a igualdade que se procura conferir às unidades federativas utilizando-se, quando necessário, arranjos institucionais que levem à diferenciação entre elas - não pode jamais ofuscar o fato de que as partes de uma Federação, sob os mais variados aspectos, são, invariavelmente, distintas em graus de desenvolvimento econômico ou social ${ }^{42}$. A proposta de maior proeminência no federalismo assimétrico é, portanto, a de proporcionar o devido tratamento constitucional aos desníveis regionais grosseiros que, caso deixados soltos para sofrer as inúmeras influências da política, muito provavelmente impediriam a subsistência do pacto federativo em condições reais de assegurar idêntico atendimento às necessidades apresentadas por todas as unidades autonômicas.

Muito mais do que assegurar a sustentação equilibrada dos laços associativos de partes díspares, a ponderação das contingências territoriais que dimanam das distintas realidades vivenciadas pelos entes federados atesta a imprescindibilidade de criarem-se

\footnotetext{
${ }^{39}$ Cf. A. Machado PAupÉRIO, O Município e seu Regime Jurídico no Brasil, $2^{\mathrm{a}}$ ed., Rio de Janeiro, Forense, 1973, p. 112.

${ }^{40}$ Cf. Symmetry and Asymmetry as Elements of Federalism: a Theoretical Speculation, in The Journal of Politics, vol. 27, no 1, feb. 1965, pp. 872-873.

${ }^{41}$ No que respeita ao papel do empirismo como método indicado para conferir substância e funcionalidade à Ciência Política e ao Direito Constitucional, verificar as obras de PABLo LuCAS Verdú, Principios de Ciencia Política, Tomo I, $3^{\mathrm{a}}$ ed., Madrid, Tecnos, 1973, p. 89; e Giovanni SARTori, Teoria Democrática Revisitada, vol. II: As Questões Clássicas, São Paulo, Ática, 1994, pp. 21-22.

${ }^{42}$ Cf. Augusto Zimmermann, Ob. cit., p. 61.
} 
aparatos estatais racionalizados. Ao Direito Constitucional competirá fixar a coordenação sistemática entre todos os níveis de organização do poder, sem, contudo, fazer das exigências de natureza técnica fatores de negação dos destacados valores políticos que desencadearam o processo de descentralização política ${ }^{43}$. Em outras palavras, embora seja indicado construir estruturas políticas operativas, é declaradamente reprovável fazer com que o Estado federal evolua em desconformidade com os painéis social, histórico, econômico e cultural característicos de cada país, porque a organização política não pode ficar petrificada em sua forma tradicional, aquela moldada nos textos legais responsáveis pelo seu surgimento ${ }^{44}$.

A importância de se investigar com profundidade as necessidades demandadas pelos indivíduos e pela tessitura social, sobre os quais incide a autoridade dos órgãos públicos, consubstancia-se, portanto, em instrumento viabilizador da constante evolução das instituições estatais. Com isso, também é evitável a instauração do preocupante quadro de descompasso entre a realidade e a configuração dos órgãos estatais existentes. E é a partir dessa orientação que a proposta teórica do federalismo assimétrico passou a ser cada vez mais evocada como engenho tendente a permitir que se conheçam as vantagens, as objeções e as soluções possíveis encarnadas na adoção do sistema federativo em determinado território ${ }^{45}$.

É justamente esse patente empirismo, norteador da investigação sobre a pertinência ou não do emprego do federalismo no plano da organização dos Estados compostos, que impede a elaboração de uma definição única e precisamente delimitada acerca da ideia de assimetria federativa. Tamanho é o significado da análise do Estado federal sob pontos de vistas particularizados, considerando-se fatores intrínsecos aos territórios reunidos pelos laços integradores da Federação, que ROBERT AGRANOFF chega a afirmar que inexiste "uma real conclusão acerca da questão da assimetria no federalismo"46. Em perspectiva similar, deve-se ter em mente que o princípio federal é dotado de sensível flexibilidade em matéria de arranjos jurídico-institucionais, aspecto que claramente é refletido na configuração de inúmeras possibilidades de concretização das estruturas que alicerçam a descentralização política, e, por decorrência lógica, também interfere no reconhecimento de variados modos de constatação da vertente assimétrica do Estado federal.

${ }^{43}$ Cf. José JuAn GonZÁlez EnCInAR, El Estado Federal Asimétrico y El Fin Del Estado, in El Estado de las Autonomias, Antoni Monreal (ed.), Madrid, Tecnos, 1991, p. 61.

${ }^{44}$ Cf. Fernando Whitaker Da Cunha, Direito Político Brasileiro, Rio de Janeiro, Forense, 1978, p. 168.

${ }^{45}$ Cf. Charles D. Tarlton, Ob. cit., p. 872.

${ }^{46}$ Power Shifts, Diversity and Asymmetry, in Accommodating Diversity: Asymmetry in Federal States, Robert Agranoff (ed.), Ob. cit., p. 22. 
Esse dado é explorado por ISIDRE MOLAS, ao sublinhar que os sistemas federais são tão diversos quanto a pluralidade de exigências que devem ser satisfeitas a cada um deles. As dimensões territoriais, as motivações históricas que levaram à criação de alguns Estados, a diversidade religiosa, as diferenças raciais e culturais ou, simplesmente, os critérios sobre um governo mais eficaz, tudo isso influi nas características apresentadas por uma Federação. Em complemento, o autor registra ainda que as realidades que geram sistemas de governo federais são impossíveis de serem reduzidas a um único modelo ou a uma só linha de evolução institucional, daí o porquê as principais coordenadas do esquemas de organização dos ordenamentos jurídicos plurais de Estados compostos acabam aparecendo muito antes da própria existência de uma teoria descentralizadora, pois não deixa se ser os conflitos e as soluções secularmente existentes no território no qual o Estado federal será assentado ${ }^{47}$.

No Brasil, no que respeita a essa percepção, paradigmáticas observações foram tecidas por ORLANDO BITAR, que declara categoricamente não haver regime federal único: o que existe é, ao revés, uma visível pluralidade de sistemas federativos, de modo que "a federação helvética, a americana, a australiana, a canadense, a argentina, a brasileira não serão regime federal. São Federações diferenciadas. Cada uma dessas comunidades políticas representa uma superestrutura sublimada de mil infraestruturas: econômica, étnica, sociológica, política, religiosa, enfim - temperamental, porque os povos têm os seus temperamentos, como os indivíduos singulares [...]. Com tais determinantes subjacentes tão radicalmente divergentes, como falar em Estado federal que englobe todas aquelas sociedades políticas" ${ }^{\prime 4}$.

Com propriedade e na mesma direção, FERnANDA Dias MENEZES DE AlmeIDA identifica essa irrestrita possibilidade de conformação estrutural do sistema federativo como marca indelével do arcabouço institucional do próprio Estado federal, assinalando que o federalismo é, em verdade, um salutar incentivo à criatividade, já que - mantido um núcleo irredutível de princípios característicos do regime federativo - torna-se possível identificar muitos federalismos, diferentes entre si, sob vários e relevantes aspectos ${ }^{49}$.

\footnotetext{
${ }^{47}$ Cf. El Federalismo entre La Ideologia y Las Técnicas para Resolver Problemas Práticos, in El Estado de las Autonomias, Antoni Monreal (ed.), Ob. cit., p. 38.

${ }^{48}$ Organização Constitucional do Brasil, Prova (concurso de Direito Constitucional) - Universidade do Pará, Belém, 1955, ora in Obras Completas de Orlando Bitar: Estudos de Direito Constitucional e Direito do Trabalho, vol. 2, Rio de Janeiro, Renovar, 1996, p. 185

${ }^{49}$ Cf. Considerações sobre o Rumo do Federalismo nos Estados Unidos e no Brasil, in Revista de Informação Legislativa, Brasília, ano 24, n 96, out./dez. 1987, p. 58. Impressão idêntica é externada por PETER HÄBERLE ao registrar que "o federalismo, em razão da pluralidade de seus distintos empregos, manifesta-se como um cenário de experimentação, com formas que refletem acertos e erros, inovação e
} 
Inexiste, portanto, um único e universal modelo de Federação, de modo que cada Estado que opte pela forma federativa deverá elaborar um sistema de descentralização política que melhor se amolde às necessidades e às aspirações que figuram como essenciais para a vitalidade da organização estatal criada.

As dimensões configuradoras do sistema federativo dependem diretamente das contingências políticas e dos contextos territoriais em que esse será empregado, de forma que muitas são as variáveis a serem computadas no processo de adoção e de sedimentação de cada Federação, como, por exemplo, o tamanho do território, os objetivos desencadeadores do uso do federalismo como ferramenta de organização política, a homogeneidade ou heterogeneidade reinante no meio social, a diversidade sociocultural e as disparidades socioeconômicas intrínsecas à realidade a ser disciplinada, além de aspectos relacionados à cultura política das respectivas sociedades, tal qual ocorre com tradições centralistas ou descentralizadoras que regerão, em boa medida, as características do pacto federativo a ser formado ${ }^{50}$.

Inexiste, portanto, um esquema invariável e universal de Federação a ser aplicável a todos os países que cogitem adotar essa forma de Estado, de modo que inúmeras são as formulações e as materializações possíveis que se podem conferir ao Estado Federal. O que se exige é a observância da essência material do regime federativo, a fim de coibir deturpações e rupturas das bases fundantes do federalismo. Além disso, essa advertência também é hábil para impedir a instauração de fraudes constitucionais que conduzam ao enfraquecimento da Constituição e da própria ideia de regime federativo, tal qual aconteceu com a experiência brasileira do denominado federalismo de integração ${ }^{51}$. Nesse capítulo da história constitucional do Brasil, ocorrido no final da década de 1960, a Federação sofreu sério comprometimento estrutural, motivado pelo abandono do paradigma democrático como diretriz da atuação dos órgãos estatais ligados ao poder central. À época, a União recebeu extenso e significativo rol de competências - as mais

conservadorismo. Cada Estado constitucional federal sempre estará caminhando, sempre estará em processo de construção", Ob. cit., p. 180. Também vale consultar HARTMUT MAURER, Contributos para o Direito do Estado, Porto Alegre, Livraria do Advogado, 2007, pp. 149-150.

${ }^{50}$ Cf. DieTer Nohlen, El Federalismo Alemán: su Evolución hasta el Presente y Reforma a Futuro, in Federalismo y Regionalismo, Diego Valadés e José María Serna de la Garza (coord.), México, Universidad Nacional Autónoma de México, 2005, p. 1.

${ }^{51}$ Sob o falacioso argumento de se buscar a promoção do completo desenvolvimento da economia nacional, exigindo-se, como consequência, o redimensionamento da percepção do fenômeno político relacionado à Federação brasileira - porque existiria uma ligação indissolúvel entre política e economia, esta demandando contundente planejamento a ser viabilizado no país mediante a adoção de um plano de integração nacional -, foi levantada a conveniência de implantação do federalismo de integração, cujos aspectos definidores são expostos por Alfredo BuZAid, O Estado Federal Brasileiro, Brasília, Ministério da Justiça, 1971, pp. 4041. 
importantes, na verdade -, de forma a permitir que esse ente federado planejasse, dirigisse e controlasse rigorosamente a atuação dos Estados-membros, quase os reduzindo à condição de unidades desprovidas de autonomia política ${ }^{52}$.

Acerca da ampla adaptabilidade do sistema federativo, vale pontuar que, no âmago das estruturas originadas em decorrência dos valores primaciais do federalismo, sempre existirá o comando axiológico que estabelece a necessidade indeclinável de harmonização dos distintos reclamos de uniformidade e de diversidade. Essa ordem conciliatória decorre da importância que é atribuída aos esquemas institucionais de descentralização política em matéria de compatibilização de interesses contrapostos. Soldados pelo pacto federativo, sempre haverá dura contraposição de interesses: de um lado, estarão as demandas forjadas pelo próprio Estado federal - sempre cioso de unidade -, e, de outro, os interesses apresentados pelas partes que o integram, os quais transformam a autonomia política em ferramenta garantidora da diversidade ${ }^{53}$. Não é por outra razão que MANUEL GARCIAPELAYO enfatiza ser "unidade dialética de duas tendências contraditórias: a tendência da unidade e a tendência da diversidade" ${ }^{54}$ a missão elementar colocada à Federação.

Enxerga-se ainda que o federalismo carrega consigo outra característica de elevada significância que lhe traz, enquanto instituição política, a certeza de permanência, e, como ferramenta voltada a conferir eficiência governamental, a promessa de aprimoramento ininterrupto $^{55}$. Essa noção é retratada por FERNANDA DiAS MENEZES DE ALMEIDA na verificação de que "a flexibilidade do regime federativo não permite apenas que projeções diferentes dele coexistam num mesmo momento histórico. Enseja ainda que o regime não envelheça, conservando a sua vitalidade com o passar do tempo, recriado conceitualmente na medida dos imperativos de ordem social, econômica e política que se vão colocando na evolução natural das sociedades" ${ }^{, 56}$.

${ }^{52}$ Cf. Fernanda Dias Menezes de Almeida, Competências na Constituição de 1988, Ob. cit., p. 28.

${ }^{53}$ Nesse sentido, grifa PABLo A. RAMElla que "o princípio fundamental do federalismo é que esse regime não aspira nem a fundir nem a separar, mas a articular, a guiar. Estabelece-se a unidade dentro da diversidade, baseando-se num critério de flexibilidade que permite o estabelecimento de complementação entre os conceitos de autonomia e ordem, de liberdade e de proteção. O federalismo, que responder a necessidades reais e não a esquemas teóricos preconcebidos, terá sua base sociológica, e em princípios de autonomia e de participação, sua base moral em um sentimento muito vivo de bem comum", Ob. cit., p. 27.

${ }^{54}$ Derecho Constitucional Comparado, $3^{\mathrm{a}}$ ed., Madrid, Manuales de la Revista de Occidente, 1953, p. 218.

${ }^{55}$ A busca pela eficiência revela ser marca do federalismo desde sua gênese, pois AleXANDER HAMILTON levantou a bandeira federalista no século XVIII sob o argumento inicial de contornar a "inequívoca demonstração de ineficiência" do governo daquela época, ALEXANDER HAMILTON, JAMES MADISON e JOHN JAY, O Federalista, Brasileira, Universidade de Brasília, 1984, p. 99.

${ }^{56}$ Cf. Considerações sobre o Rumo do Federalismo nos Estados Unidos e no Brasil, Ob. cit., p. 58. Convergem, nessa percepção, GiLberto BerCovici, Dilemas do Estado Federal Brasileiro, Porto Alegre, Livraria do Advogado, 2004, p. 145; RAUl MACHADO HoRTA, Tendências Atuais da Federação Brasileira, in Cadernos de Direito Constitucional e Ciência Política, ano 4, n 16, jul/set de 1996, p. 7; e Paulo 
Sob esse ponto de vista, o federalismo deve ser compreendido como princípio fundamental político, consubstanciado na liberdade de formação unificadora de totalidades políticas diferentes $^{57}$, e é em função disso que essa forma de Estado assume a natureza de mandamento nuclear na ordem constitucional brasileira. Tamanha é a relevância do Estado federal para as instituições político-constitucionais do país, que o constituinte vedou expressamente qualquer tentativa de abolir sua existência do contexto político nacional, tal qual se verifica no preceito estampado no art. $60, \S 4^{\circ}$, inciso I, da Constituição Federal de $1988^{58}$. Essa relevante disposição orienta a confecção de todos os arranjos voltados a enaltecer e a maximizar a Federação, os quais, apesar do dinamismo que é ínsito ao regime federativo $^{59}$, jamais poderão suprimir os aspectos mínimos da autonomia política atribuída aos respectivos entes federados.

A multiplicidade de combinações ofertadas pelo sistema federativo também constitui, por óbvio, sinal também identificável na assimetria federativa. Esse aspecto acaba por atribuir aos modos de expressão dessa vertente do federalismo natural mimetismo. Não obstante, o fato de o Estado federal assimétrico ter como característica fundamental a comprovação da existência de desigualdades jurídicas e competenciais entre as unidades federadas, em regra, situadas no mesmo patamar governamental, os elementos informadores da assimetria são variáveis nos diversos cenários nos quais acabam sendo empregados $^{60}$. E isso pode ocasionar divergências radicais de um país a outro, como restou comprovado em exaustivo estudo realizado por DIRCÊO TORRECILLAS RAMOS ${ }^{61}$.

Diante das considerações lançadas, infere-se que a assimetria passou a figurar no universo federativo porque essa forma de Estado sofre constantes alterações no tempo e no

Gustavo Gonet Branco, Organização do Estado, in Curso de Direito Constitucional, Gilmar Ferreira Mendes, Inocêncio Mártires Coelho e Paulo Gustavo Gonet Branco, São Paulo, $4^{a}$ ed., Saraiva, 2009, p. 852.

57 Cf. Konrad Hesse, Elementos de Direito Constitucional da República Federal da Alemanha, Porto Alegre, Sérgio Antonio Fabris Editor, 1998, pp. 219-220.

58 “Art. 60. [...]

$\S 4^{\circ}$ - Não será objeto de deliberação a proposta de emenda tendente a abolir:

I - a forma federativa de Estado".

${ }^{59}$ Chancela essa orientação CELSO RIBEIRO BASTOS, para quem "a federação não é um esquema jurídico que possa ser transformado em realidade tão-só pela enunciação do Texto Constitucional. A federação, como a democracia, é um processo que necessita constante aperfeiçoamento e adaptação a novas realidades", Curso de Direito Constitucional, 15ª ed., São Paulo, Saraiva, 1994, p. 246.

${ }^{60}$ Cf. PNUD (Programa das NaÇões UnidAS PARA O DESENVOlvimento), Relatório do Desenvolvimento Humano 2004: Liberdade Cultural num Mundo Diversificado, Sakiko Fukuda-Parr (coord.), Lisboa, Mensagem Serviços de Recursos Editoriais, 2004, p. 50; Alain-G. Gagnon e Charles GiBBS, The Normative Basis of Asymmetrical Federalism, in Accommodating Diversity: Asymmetry in Federal States, Robert Agranoff (ed.), Ob. cit., p. 93; e ENRIQuE Alvarez CondE, Asimetría y Cohesión en el Estado Autonomico, in Asimetría y Cohesión en el Estado Autonómico: Jornadas sobre el Estado Autonómico: Integración y Eficacia, INAP (Instituto Nacional de Administración Pública), Ob. cit., p. 86.

${ }^{61}$ Cf. O Federalismo Assimétrico, Ob. cit., pp. 60-61. 
espaço, e, por força disso, exige sempre novos e eficientes esquemas de acomodação das diversidades regionais. Certamente, foi a incessante busca de equilíbrio no conflito dialético firmado entre o poder central e as partes do conjunto o principal fator que conferiu prestígio à tese da assimetria, na medida em que ela se propõe a evidenciar e a harmonizar o grau de tensão nos sistemas federativos. Além disso, como existe patente multiplicidade de Federações no mundo, verifica-se também, como corolário, um semnúmero de arranjos possíveis de serem experimentados a partir da ideia de federalismo assimétrico, dependendo das características e das forças sociais influentes em cada realidade na qual o Estado Federal está assentado.

\section{I.3.1. "Assimetrias Estruturais" e "Assimetrias Relacionais"}

Ao se considerar os inúmeros modos possíveis de proceder à positivação das assimetrias no texto constitucional, ganha especial significado a análise das chamadas "assimetrias jurídicas", tomando, para tanto, como ponto de partida, o conteúdo normativo condensado nessas fórmulas de promover e de respeitar a diferenciação entre unidades federadas. Imbuída desse espírito investigativo, ESTHER SEIJAS VILLADANGOS propõe distinguir as "assimetrias de direito" em duas subespécies: "assimetrias estruturais" e "assimetrias relacionais" $"$.

Compreendidas em sua faceta estrutural, as assimetrias instrumentalizadas em mandamentos consagrados na Lei Maior de um Estado composto para integrar e informar realidades complexas correspondem àquelas perceptíveis mediante a análise estática de organizações estatais. Referem-se essencialmente à posição diferenciada que se atribui às unidades territoriais componentes do sistema em virtude de fatores diversos, apresentados pelas próprias unidades periféricas, como é o caso da população, do tamanho territorial, da riqueza, além de outros dados de natureza étnica, cultural e histórica ${ }^{63}$. Assim, compreende-se que a decisão de gravar em determinado ente federado uma "assimetria estrutural" retrata louvável preocupação em garantir-lhe condições de governabilidade, não

\footnotetext{
${ }^{62}$ Cf. Ob. cit., pp. 295-296.

${ }^{63}$ Michael BuRguess e Franz GRESS registram os pressupostos que levam ao surgimento de assimetrias jurídicas, destacando, em síntese, a necessidade de cultura e tradição políticas lastreadas no federalismo; de diferenças sociais; de vinculação cultural de grupos sociais específicos a um território; de consideráveis disparidades sócio-econômicas, além de diferentes índices populacionais entre as regiões, Cf. Asymmetrical Federalism in Canada, the United States and Germany: Comparative Perspectives, in Accommodating Diversity: Asymmetry in Federal States, Robert Agranoff (ed.), Ob. cit., pp. 170-178.
} 
obstante o fato de tal unidade autônoma passar a apresentar posição singular em relação aos seus congêneres ${ }^{64}$.

A título de exemplo, interessa citar algumas manifestações do fenômeno políticoconstitucional da "assimetria estrutural", destacando-se a situação retratada em países como Malásia, Canadá e Índia. A complexidade territorial desses países fez com que as diferenças internas fossem ajustadas no sistema constitucional de repartição de competências mediante mecanismos diversos entre si. A Federação malaia, criada em 1963, somente conseguiu incorporar o Estado de Bornéu conferindo-lhe acentuado grau de autonomia, o que o diferenciou decisivamente das demais unidades federativos. Idênticas situações são observadas no Canadá e na Índia. O primeiro valeu-se da assimetria para acomodar particularidades culturais apresentadas pela província de Quebec, no tocante à religião católica, a educação e o uso do vernáculo francês, além do direito codificado e da proximidade de funcionamento dos tribunais judiciários daquela província aos parâmetros da Civil Law ${ }^{65}$, pontos que colocam o referido ente em evidente contraposição com as demais províncias canadenses. Já a Federação indiana, por sua vez, recorreu aos condicionamentos do federalismo assimétrico para ajustar e prestar satisfatório atendimento a questões surgidas na órbita da integração do conjunto de entes federados que têm em seu contingente populacional grupos étnicos díspares e altamente conflitantes, como se deu com o Estado de Jammu e da Caxemira ${ }^{66}$.

As "assimetrias relacionais", noutro giro, estarão atreladas às "assimetrias estruturais", representando a projeção exterior do status diferenciado que se confere aos entes em decorrência dos fatores relatados. Estão inseridas, portanto, no âmbito de ação comum travada entre as partes formadoras da Federação, o que exige considerá-las sob o prisma das relações intergovernamentais. Sua corporificação ocorre por meio das conexões estabelecidas por um determinado ente diante das demais unidades subnacionais ou do poder central, sendo verificadas principalmente nos graus de interferência das partes na formação de decisões políticas pelo conjunto ${ }^{67}$. Ademais, como corolário, tem-se que esse

${ }^{64}$ Cf. Esther Seijas Villadangos, Ob. cit., p. 295-296.

${ }^{65}$ Sobre a preservação do sistema romano-germânico de Direito em determinados espaços da América do Norte, verificar RENÉ DAvid, Os Grandes Sistemas do Direito Contemporâneo, São Paulo, Martins Fontes, 2002 , p. 78.

66 Cf. Ronald L. Watts, Comparing Federal Systems, Ob. cit., pp. 66-68. Sobre a acomodação da diversidade regional no Estado federal da Índia, consultar HARIHAR BHATTACHARYYA, Federalism and the Regional Accommodation of Identity in India, in Federalismo y Regionalismo, Diego Valadés e José María Serna de la Garza (coord.), Ob. cit., pp. 571-487.

${ }^{67}$ Cf. Esther Seijas Villadangos, Ob. cit., 2003, p. 296. 
tipo de ajuste jurídico, em regra, acompanha os sistemas de Estado federal que praticam o denominado federalismo cooperativo ${ }^{68}$.

É oportuno registrar aqui a importância histórica que as "assimetrias relacionais" têm para o constitucionalismo. Foram elas as responsáveis pela deflagração da tese do federalismo assimétrico por CHARLES D. TARLTON, quando esse cientista político, depois de empreender acurado estudo sobre os diferentes e particulares motivos que determinavam a instauração (e a intensificação) de conflitos entre a União e os Estadosmembros da Federação estadunidense, sentenciou que "o alívio das tensões e da discordância que geralmente acompanham os sistemas assimétricos não requer um maior reconhecimento dos elementos da diversidade, nem sua proteção por meio de complicados processos de federalização expansiva, mas, em verdade, uma maior coordenação e coerção exercida pelas autoridades nacionais do sistema" ${ }^{\prime \prime}$.

Em relação à interação política, há exemplos de graus de assimetria compreendidos não diretamente a partir do exame da positivação insculpida no texto constitucional, mas das relações intergovernamentais que a Constituição autoriza aos membros da Federação acordar. Nessas hipóteses, os postulados assimétricos servem, em geral, como eficiente recurso de acomodação de estágios dissonantes em matéria de desenvolvimento econômico e político. Ilustra tal forma de assimetria a Rússia, que, a despeito de estar estruturada por um texto que considera formalmente simétricos todos os membros federados, protagoniza frequentes acordos bilaterais entre o poder central e as unidades periféricas, sendo essas relações marcadas por aclarado tratamento assimétrico com o objetivo de permitir que as diversas necessidades de cada um dos entes sejam supridas de modo conveniente e particularizado.

Ademais, é interessante sublinhar a possibilidade de coexistirem as duas modalidades de manifestação da "assimetria de direito", isto é, a previsão constitucional de desníveis de competência fixados para as partes e a celebração de acordos específicos e não padronizados entre o poder central e seus membros subnacionais ou ainda no universo restrito desses, tal qual acontece na realidade erigida na Bélgica ${ }^{70}$.

\footnotetext{
68 A propósito, SiLENE PINHEIRo CRUZ MinitTi apresenta interessante delimitação conceitual de relações intergovernamentais, pontuando que "traduzem as relações intergovernamentais todas as interações que se passam no âmbito de um Estado federal entre seus entes componentes, quais sejam, o governo central e os governos subnacionais e seus órgãos e agentes, abrangendo a cooperação, a coordenação, a co-participação nas decisões e nos conflitos, que se instrumentalizam por contatos formais e informais", As Relações Fiscais Intergovernamentais nas Constituições Brasileiras, Tese de Doutorado, Faculdade de Direito da USP, São Paulo, 2004, PP. 49-50.

${ }^{69}$ Ob. cit., p. 874.

${ }^{70}$ Cf. Ronald L. Watts, Comparing Federal Systems, Ob. cit., pp. 66-68.
} 
Independentemente do tipo de federalismo assimétrico que se pratica, o fato é que, por força da envergadura da matéria, essa realização somente será exitosa após o Estado federal submeter-se a progressivas reformulações com o intuito de sempre buscar os melhores ajustes para as problemáticas diferenças regionais. Por tal razão, PETER PERNTHALER esclarece ser "a responsabilidade de atuação para atender a esse propósito reformador distribuída igualmente entre a Federação e os seus respectivos entes federados" ${ }^{, 71}$, o que denota patente advertência para que as sucessivas reformas constitucionais sejam feitas de modo seguro e alicerçado. Sem profundas reflexões e decantada vontade política de superar as desigualdades regionais, jamais haverá probabilidade de construir sistemas federativos assimétricos que consigam atender aos autênticos propósitos que justificam essa possível configuração do Estado federal.

\section{I.4. A Ambivalência da Diversidade Regional: os Dois Caminhos Possíveis das Federações Heterogêneas}

O federalismo, em sua integralidade, é um fato cuja complexidade denota características que transcendem o campo da conformação simultânea e harmônica do poder de unidades locais ao lado da unidade global, como bem assinala JOSÉ ALFREDO DE OLIVEIRA BARACHO. Dada a sua magnitude, as Federações adquirem, em geral, projeções que se fazem sentir nos campos da política, da economia, da ordenação social, da cultura, entre outros. Certo dessa dimensão maior, entende o autor que uma técnica que deveria ser utilizada apenas como mecanismo de pulverização do poder político acaba se transmutando em "fenômeno social de estrutura"72.

Desse modo, os Estados federais concretizados na prática e dignos de ser considerados experiências bem-sucedidas demonstram que, apesar da premente necessidade de se resguardar a unidade nacional, as tradições regionais exigem que sejam institucionalizadas maneiras de manter e de respeitar a diversidade que dimana dos atores federativos subnacionais ${ }^{73}$. A ordem federal institucionalizada deve ter como missão primeira fazer com que a hegemonia do poder central possa coexistir com a diversidade advinda das unidades federadas. E, na obtenção dessa difícil equação, adverte LOURIVAL VILANOVA que "o quantum de simetria não pode ir além de certo ponto sem o Estado

${ }^{71}$ Lo Stato Federale Differenziato: Fundamenti Teorici, Conseguenze Pratiche ed Ambiti Applicativi nella Riforma del Sistema Federale Austríaco, Bologna, Il Mulino, 1998, pp. 111-112.

${ }^{72}$ Teoria Geral do Federalismo, Ob. cit., p. 317.

${ }^{73}$ Cf. KARl Loewenstein, Teoria de la Constitución, Barcelona, Ariel, 1976, p. 355. 
federal desfazer-se; o quantum de dissimetria não pode ir além de certo ponto sem o Estado federal desfazer-se numa pluralidade de Estados soberanos" ${ }^{\text {"74 }}$.

É justamente na busca desse ponto de equilíbrio que a temática do federalismo é suscitada pelos teóricos que se dedicam ao estudo da natureza, da arquitetura e do funcionamento dos chamados Estados territorialmente compostos. Não é complicado concluir que o assunto da compatibilização da diversidade não tem nada de inédito no campo de estudo dos Estados federais, entretanto, a corrente que defende a assimetria federativa trouxe possibilidades nunca antes aventadas sobre essa questão. Assim é que ESTHER SEIJAS VILLADANGOS diz que a assimetria nada mais é do que "um novo vestido para um velho corpo, problemático e conflitivo, como é o da integração territorial nos Estados que aglutinam em sua estrutura diferentes culturas, distintos conjuntos normativos e diversas maneiras de conceber em sua forma o referido Estado" ${ }^{\text {75. }}$.

Em verdade, o federalismo assimétrico pode ser compreendido como um esforço teórico voltado a explicar e a informar os sistemas de descentralização política adotado por Estados que buscam construir um modelo alternativo e juridicamente viável de articulação do poder. São múltiplos os fatores que podem chamar a assimetria para o texto constitucional estruturante da Federação, mas o certo é que os mecanismos dela derivados sempre irão objetivar a pacificação institucional por meio da diferenciação racionalmente controlada do exercício das competências materiais e legislativas titularizadas pelas partes federadas. E essas desigualdades jurídicas plasmadas nos dispositivos constitucionais tendem a converter-se em habilidoso e eficiente meio de assegurar a convivência pacífica e ordenada entre realidades dissonantes e, não raro, hostis entre $\mathrm{si}^{76}$.

Não é absurdo afirmar que os desenhos teóricos ligados ao federalismo assimétrico correspondem ao aperfeiçoamento da lição preceituada por ALEXANDER HAMILTON, nos primórdios da elaboração da ideia federativa, sintetizada na recomendação de que somente "uma união sólida terá a máxima significação para a paz e para a liberdade dos Estados, como barreira contra facções e insurreições internas" ${ }^{\text {77 }}$. Desse modo, a assimetria constitui inegável desdobramento da evolução das formas básicas de se garantir a aplicabilidade dos institutos fundantes do sistema federativo. É ela resultado do aperfeiçoamento dos conceitos elementares e definidores dos aspectos cardeais de todo Estado federal.

\footnotetext{
${ }_{75}^{74}$ As Estruturas Lógicas e o Sistema do Direito Positivo, São Paulo, Revista dos Tribunais, 1977, p. 124.

${ }^{75}$ Ob. cit., p. 15.

${ }^{76}$ Cf. Francisco CaAmaño, Ob. cit., p. 359.

77 AleXAnder Hamilton, James Madison e John Jay, Ob. cit., p. 141.
} 
Com razão, observa UADI LAMMÊGO BULOS que a assimetria federativa "não se trata de uma modalidade nova de Teoria Geral das Federações, e sim de um método para estudar uma característica intrínseca do fenômeno federativo: a desconformidade" ${ }^{\text {"78 }}$. Sem dúvida, foi o abandono do projeto político dominante na primeira metade do século XX orientado pelo mandamento de fazer do Estado uma realidade coesa, dotada de identidade cultural homogênea, desprendida de quaisquer preocupações concretas com eventuais diversidades acolhidas no momento de seu surgimento e durante seu desenrolar - que criou inicialmente um ambiente propício ao florescimento dos conceitos subjacentes ao federalismo assimétrico ${ }^{79}$. Frente a esse dado, confirma-se também com a vertente assimétrica do federalismo a afirmação de PEDRO CALMON de que "o regime federativo foi antes realizado do que compreendido" $" 80$.

Em menor ou maior intensidade, o princípio federativo busca amenizar as consequências que derivam da conclusão de que os "Estados particulares das múltiplas federações não se encontram sempre com a mesma capacidade para dirigir os negócios, que mais de perto lhe interessam" ${ }^{\prime 1}$. Essa comprovação empírica leva à formulação de diversificadas modalidades e técnicas de repartição de competências, as quais variam no tempo e no espaço, conforme os inúmeros projetos constitucionais manifestados pelos sistemas federativos em operação no mundo. Somente quando for verificado que dispensar idêntico tratamento a todos os entes federados de um Estado composto formado por partes altamente heterogêneas importa ameaça à subsistência do pacto federativo soldado é que a assimetria federativa deve ser utilizada.

Diante da observação aposta por PONTES DE MIRANDA, atentando para o fato de que "um dos apriorismos que mais embaraçam as soluções, nos problemas construtivos do Estado federal, é o de se pressuporem igualmente avançados na cultura os diferentes trechos do território nacional e das populações" ${ }^{82}$, toda invenção que percorra caminho contrário a essa constatação merece, ao menos cientificamente, credibilidade por parte dos estudiosos do federalismo. Esse é o caso do federalismo assimétrico, cujo ponto de destaque está notadamente na tentativa de prevenir a fragilização do pacto federativo em virtude de construções jurídicas que adotam, na ocasião em que se criam os Estados

\footnotetext{
${ }^{78}$ Curso de Direito de Direito Constitucional, São Paulo, Saraiva, 2007, p. 716.

${ }^{79}$ Cf. PNUD (Programa das NAÇões Unidas PARA O DESENVOLVIMENTO), Ob. cit., p. 47.

${ }^{80}$ Curso de Direito Público, Rio de Janeiro, Freitas Bastos, 1938, p. 187.

${ }^{81}$ Oswaldo Aranha BandeIRa de Mello, Natureza Jurídica do Estado Federal, São Paulo, Prefeitura do Município de São Paulo, 1948, p. 81.

${ }^{82}$ Ob. cit., p. 160.
} 
federais, a ficção de que as unidades do conjunto são todas homogêneas e gozam de idênticos níveis de desenvolvimento.

Como se pode inferir, a assimetria pugna para desmitificar a ideia equivocada de que unidade nacional é obtida por meio da crença de que é preciso atribuir, no texto constitucional, o mesmo grau de autonomia para as partes federadas, independentemente das condições econômicas, sociais e culturais apresentadas por elas. Além disso, busca coibir que a autonomia política transforme-se em elemento deflagrador do agravamento das diversidades estampadas pelas unidades de uma Federação. Sua empregabilidade está condicionada, desse modo, à constatação de que o ato de conceder a mesma quantidade de poder político às partes do concerto federativo, em vez de possibilitar a exploração das potencialidades apresentadas por elas, em especial nos Estados territoriais compostos marcados por excessiva heterogeneidade territorial, tem como efeito a erosão das bases que conferem sustentabilidade ao próprio sistema federativo.

A propósito, atingir o âmago da proposta teórica do federalismo assimétrico - e, a partir dela, extrair as diretivas para a aplicação concreta das ideias que lhe são pertinentes exige que se vá muito além do que OswaLdo ARANHA BANDEIRA DE MELlO anotou como sendo importante para a fixação de sistemas de competências federativas. Mais que evidenciar uma "grande disparidade na repartição das competências dos Estados federais, pois dificilmente se pode fazê-la, atendendo-se a um princípio inflexível" ${ }^{, 83}$, a assimetria requer que se computem não apenas as características da Federação considerada em sua faceta unitária. Antes, demanda que as peculiaridades de cada uma das peças que compõem o concerto federativo sejam equacionadas harmoniosamente para que haja uma segura distribuição de competências entre elas.

A visão centrada exclusivamente no todo é amainada e, com isso, busca-se privilegiar as partes no tocante à repartição de poderes no Estado federal, sendo permitida, inclusive, a diferenciação entre as unidades federadas em matéria de atribuição de competências. Nessa quadra, Peter Pernthaler considera que a fórmula do Estado federal assimétrico exprime, em sua natureza, um dado óbvio: a certeza de que os membros de uma Federação são, por essência, diferentes entre si, uma vez que o próprio ideário que confere significado ao princípio federativo pressupõe esse pluralismo territorial. As patentes diferenças e contradições que porventura existam no meio social serão traduzidas em disposições jurídicas e políticas desenhadas com o intuito de eliminar ou, no mínimo,

\footnotetext{
${ }^{83}$ Ob. cit., p. 81 .
} 
reduzir as incongruências que teoricamente inviabilizariam a construção de laços associativos vigorosos ${ }^{84}$.

Essa capacidade de acomodação dos interesses específicos das partes federadas, assim como das demandas singulares apresentadas pelas mesmas, deve ser manifestada substancialmente mediante a elaboração de um conjunto sistêmico de mecanismos habilitados a estabelecer um padrão operativo e coeso de organização política. É aconselhável ainda que o compromisso de respeitar a diversidade vivenciada pelos entes autônomos esteja consagrado no texto constitucional, pois somente assim haverá garantias mínimas de que a compreensão e a preservação da complexidade territorial dos Estados compostos passarão a ser consideradas pelas instituições do país. Os arranjos que forem idealizados precisarão fazer com que as feições tomadas pelo esquema federativo impliquem em preciso e sofisticado sistema de combate aos fatores que possam fragilizar a construção de um vínculo sólido e permanente entre as unidades federadas ${ }^{85}$.

A acomodação das diferenças regionais deverá também estar agasalhada na Constituição de modo transverso, em especial, pela alusão aos constantes acordos intergovernamentais firmados pelos membros da Federação. Sedimenta-se, com essa ótica, o entendimento de que a descentralização política, inexoravelmente, exigirá a realização de ininterruptas relações político-institucionais entre os componentes da Federação. Embora seja sabido que os entes federados, por óbvio, não atuam nessa seara em condições idênticas de barganha, competirá aos resultados advindos da aplicação concreta da tese do federalismo assimétrico estabelecer instrumentos aptos a evitar e a reprimir a superposição dos interesses de alguns poucos entes que estampem maiores grandezas em termos políticos, econômicos, sociais ou territoriais sobre todas as demais partes autonômicas desprovidas de tamanha representatividade.

Os mecanismos assimétricos podem ser considerados um recurso apresentado aos Estados que abrigam flagrantes contrastes para permitir o estabelecimento do desejado equilíbrio entre população, riqueza, poder e dimensão territorial em face dos integrantes do cenário federativo ${ }^{86}$, mesmo quando houver incontáveis forças que influenciem em sentido contrário. A função primordial do federalismo assimétrico reside, portanto, em possibilitar a transformação dos desníveis naturalmente existentes nos mais diversos campos de

\footnotetext{
${ }^{84}$ Cf. Ob. cit., p. 15.

${ }^{85}$ Cf. Diogo Figueiredo Moreira Neto, Parecer: O Tribunal de Contas do Município do Rio de Janeiro e a Emenda Constitucional $n^{\circ}$ 25/2000, in Revista Direito, Rio de Janeiro, vol. 5, $\mathrm{n}^{\circ}$ 9, jan./jun. 2001, p. 43.

${ }^{86}$ Cf. Nelson de Freitas Porfírio Júnior, Federalismo, Tipos de Estado e Conceito de Estado Federal, in Federalismo Fiscal, José Maurício Conti (org.), Barueri, Manole, 2004, p. 10.
} 
conformação estrutural dos entes autônomos em construções constitucionais de compensação e de equalização dos efeitos indesejados da diversidade.

A ordem imperante na assimetria consubstancia-se, como se percebe, na intenção de arquitetar-se um quadro jurídico de igualdade material entre os integrantes da Federação, sem jamais dar azo ao surgimento de uma nefasta padronização entre os mesmos - o que, em definitivo, levaria ao verdadeiro esvaziamento do conteúdo essencial do regime federativo. Sem dúvida, é possível visualizar no federalismo assimétrico uma eficiente maneira de conferir novas delimitações à principal missão entregue ao Estado federal: tal qual define GEORG JELLINEK, incumbe-se à Federação servir de base para que se construa um sistema político-organizacional derivado da pluralidade de Estados que se fundem em uma verdadeira unidade estatal ${ }^{87}$.

A propósito, vale registrar que ANNA CÂNDIDA DA CUNHA FERRAZ comunga do mesmo entendimento acima apresentado. Explica a autora que, inicialmente, a isonomia dos entes periféricos constitui o valor crucial que deve reger a estruturação de todos os regimes federativos. Todavia, alerta que a preservação da diversidade não pode importar a proibição absoluta da admissão de ajustes necessários para ordenar eficientemente a disposição naturalmente apresentada pelas unidades federadas. Então conclui que "o Estado Federal se vê obrigado a corrigir ou superar, sob pena do seu desmantelamento, desigualdades de tratamento dispensado aos entes federativos por observância do próprio princípio da igualdade. Assim, por exemplo, certos aspectos da diversidade devem ser mantidos de modo intocável, tais como a questão do respeito à língua, às tradições, às etnias etc. Mas há certos aspectos dessas diversidades entre os Estados que, se não tratados, levarão, com certeza, à própria queda do Estado Federal, tais como os econômicos, sociais e culturais" $" 88$.

FRANCISCO CAAMAÑo também confirma essa diretriz. Sintetiza que o federalismo assimétrico corresponde a "um modelo cujo principal traço configurador se circunscreve num consenso vinculante sobre a necessidade de se garantir uma desigualdade no exercício do poder em função dos territórios. Desigualdade que se converte no único modo de assegurar juridicamente a convivência pacífica (ordenada) entre comunidades desiguais" $" 89$. De fato, seria inconsequente extremismo jurídico acreditar que o texto constitucional que

\footnotetext{
${ }^{87}$ Cf. Teoria General del Estado, Buenos Aires, Editorial Albatroz, 1973, p. 579.

${ }^{88}$ Federalismo Simétrico e Federalismo Assimétrico. O Ajuste da Distribuição de Competências e de Recursos entre União, Estados e Municípios em Face de Vicissitudes de um Estado Moderno, in 10 anos de Constituição, IBDC (Instituto Brasileiro de Direito Constitucional) (coord.), Ob. cit., p. 52.

${ }^{89}$ Ob. cit., p. 359.
} 
cimenta uma determinada Federação não poderia trazer medidas de compensação e de compatibilização da diversidade territorial desse Estado. Propagar entendimento diverso indicaria, no mínimo, falta de sintonia com a orientação de que o Direito não pode subverter a realidade, inclusive quando o assunto é a organização jurídica da forma de Estado adotada.

É possível avistar ainda uma interessante relação de complementaridade entre a definição de CAAMAÑo sobre os pontos definidores da mecânica da assimetria e a memorável conclusão tirada por TORQUATO JARDIM a respeito do desafio que comumente é colocado aos concertos federativos. A adequação e a funcionalidade do Estado federal, conforme defende JARDIM, repousam no teor consignado no âmago do pacto celebrado entre os entes, já que cabe a esse acordo "estabelecer o equilíbrio sutil entre a ficção jurídica da igualdade dos entes federados e a realidade histórica de sua desigualdade sócioeconômico-educacional" $"$ "

Do que foi até aqui esquadrinhado, compreende-se então que a assimetria federativa, em termos concretos, pode ser traduzida no efetivo reconhecimento dos desníveis impregnados às múltiplas realidades das partes integrantes de um Estado federal. Diferenças que se manifestam em diversos modos de expressão, abarcando desde aspectos referentes à dimensão territorial até o poder de barganha política titularizado por determinadas unidades federativas. Independentemente do critério adotado para identificar assimetrias de fato, nota-se que a matriz irradiadora do comando de previsão de assimetrias jurídicas recomenda a realização de sério sopesamento dos fatores históricos, culturais, políticos, geográficos e econômicos que, se conflitantes e renegados pelo constituinte, podem provocar o fracasso do projeto constitucional idealizado para ser a base jurídica da Federação.

Noutra acepção possível, o federalismo assimétrico busca evitar que se incida no problemático equívoco de tão-somente consagrar a igualdade formal das unidades federadas e esperar que, dessa forma, garantir-se-á, automaticamente, o exercício em idênticos patamares da capacidade de elaborar e de implementar políticas públicas, ordenações legislativas e serviços por parte dos entes autônomos ${ }^{91}$. Nesse eito, BRIAN

\footnotetext{
${ }^{90}$ A Tridimensionalidade da Descentralização do Estado Brasileiro, in Revista de Informação Legislativa, Brasília, ano 31, n 122, mai./jul. 1994, p. 217.

91 Vale considerar, a respeito, o apontamento de CELSO FURTADO asseverando que "as desigualdades demográficas e territoriais entre Estados não são alheias às crescentes disparidades na qualidade de serviços essenciais prestados às populações. Os pequenos Estados não alcançam a densidade mínima de recursos requerida para prestar adequadamente muitos desses serviços. E muito menos para exercer uma ação efetiva no desenvolvimento econômico", A Federação por Fazer, in Rumos: Caminhos do Brasil em Debate: Quem
} 
GALLigan e RichaRd Mulgan esclarecem que a aplicação do instituto da assimetria no plano do sistema federal permite que sejam corrigidas as consequências negativas que advêm do emprego excessivo da noção de simetria entre os membros constituidores da Federação ${ }^{92}$.

Propugnar a assimetria no âmbito dos Estados federais, em geral, demonstra ser a chave para o contorno de tensões cuja fonte está na pressuposição da igualdade formal entre as unidades federadas de igual enquadramento governamental. O conceito de simetria refere-se, pois, às atribuições comuns (leia-se padronizadas) de competências partilhadas entre os entes, bem como ao tratamento e à representação invariável que esses gozam perante o poder central da Federação. Tratar simetricamente os entes federados importa em adotar a insustentável ficção de que as unidades subnacionais são, em aspectos jurídicos, todas iguais e esperar que essa manobra não deflagre movimentos de contestação do espírito federalista.

Entretanto, nem sempre essa intelecção distorcida da realidade representa apenas imprecisão dos teóricos e políticos encarregados de elaborar a engenharia constitucional do Estado. Geralmente, nos países que apresentam altos índices de disparidades regionais a pressuposta igualdade jurídica das unidades federativas torna-se uma tormentosa questão de governo, sobretudo porque contra ela depõem inquestionáveis e avultantes fatores de índole fática. Tal construção, além de não passar de mero artifício teórico, tende a resultar em lastimáveis episódios para a história do constitucionalismo, tal qual atestam os acontecimentos protagonizados pela Iugoslávia, nos anos posteriores a $1990^{93}$.

és tu, Federação? (publicação da Comissão Nacional para as Comemorações do V Centenário do Descobrimento do Brasil), São Paulo, ano 1, n 2, mar./abr. 1999, p. 41.

92 Cf. Asymmetric Political Association: The Australasian Experiment, in Accommodating Diversity: Asymmetry in Federal States, Robert Agranoff (ed.), Ob. cit., p. 57.

93 PAUl LendVAi apresenta esclarecedores apontamentos sobre o quadro que, no início dos anos 90, levou à implosão da Federação iugoslava. Em resumo, considera que naquele Estado foi instaurada uma complicada situação de impasse cujo foco estava situado, fundamentalmente, no conflito de ideias entre federalismo e centralização, uma vez que os interesses manifestados pelo poder central estavam na contramão dos anseios e projeções defendidos pelas pequenas nações e minorias. Essa tendência desestabilizadora - já presente no período entre guerras - foi sendo intensificada gradativamente durante as décadas do governo de Josip Broz Tito (1953-1980), tornando-se insuportáveis com a falência do denominado "autogoverno socialista". Numa visão mais especificada, é verificado que a situação conflituosa mencionada está radicada no fato de que a Iugoslávia foi deliberadamente criada como uma Federação composta por seis Repúblicas e duas Províncias Autônomas pertencentes à República da Sérvia. Tratava-se ainda de um Estado federal que, além de ter sido criado de modo artificial em razão de motivações políticas, era dotado de uma característica bastante singular: a possibilidade de secessão franqueada às partes do conjunto. Foi certamente essa previsão secessionista que insuflou o esfacelamento do federalismo iugoslavo quando, após a morte do carismático líder Tito, o sistema de governo vigorante, baseado em práticas absolutamente centralizadoras e conduzido, com exclusividade pelo partido comunista, não mais conseguiu manter a coesão do Estado, tampouco, apaziguar os ânimos separatistas que começaram a ganhar contornos concretos, Cf. Yugoslavia without Yugoslavs: the Roots of the Crisis, in International Affairs, vol. 67, nº 2, apr. 1999, pp. 253-256. 
A propagada significância das questões da igualdade entre os entes periféricos e da inafastável necessidade de compatibilizar os interesses variados capitaneados por essas unidades, recomenda que se empreenda uma séria e profunda releitura do tratamento destinado aos pactos federativos firmados pelos Estados compostos. Nessa quadra, convém acreditar na pertinência de promover-se a revisão das bases teóricas que justificam as Federações formadas em todos os cantos do globo, em especial aqueles modelos federativos que buscam ordenar realidades territoriais que são marcadas por profundas heterogeneidades internas.

Esses contextos territoriais díspares, ao darem suporte para a fixação de Estados compostos que alimentam a ficção da igualdade jurídica das partes federalizadas, apresentam concreta probabilidade de assistirem ao surgimento de problemáticas tensões políticas contestadoras do conjunto de instituições disposto no texto constitucional. Isso ocorre porque a Constituição, no lugar de prever fórmulas jurídicas de apaziguamento dos ânimos regionalistas, guarda certo distanciamento em relação aos interesses contrapostos dos entes federados, o que desemboca no acirramento dos ânimos regionais. Ilustra essa mecânica, o quadro verificado na Espanha com o País Basco ${ }^{94}$.

$\mathrm{Na}$ maioria dos países, entretanto, não é segredo que, erroneamente, os entes federados acabam sendo rotulados como se fossem idênticos, desprovidos de quaisquer traços particularizantes que os individualizem. Essa orientação conduz, em diferentes intensidades, à padronização do tratamento direcionado às unidades federadas pelo poder central, de modo que necessidades regionais específicas nunca são atendidas. O descaso do governo nacional em relação às demandas das diferentes regiões é, inegavelmente, principal responsável pelo indesejado afrouxamento da ligação entre os atores do Estado federal, e, por consequência, ocasiona também abalos sensíveis no funcionamento do pacto federativo, comprometendo a estrutura político-constitucional idealizada pelo constituinte ${ }^{95}$.

Quando os desníveis regionais forem muito amplos, ou as identidades dessas regiões tiverem força desmedida, poderão prevalecer os impulsos separatistas - hipótese que representa choque frontal com os valores elementares da Federação. Por pior que seja o desejo de secessão, observa ASPÁsIA CAMARGO que seu aparecimento traduz uma

\footnotetext{
${ }^{94}$ Para uma visão específica a respeito da autonomia como solução viável de pacificação de conflitos étnicos e políticos, recomenda-se a consulta de SvANT. E. CoRnEll, Autonomy as a Source of Conflict: Caucasian Conflicts in Theoretical Perspective, in World Politics, vol. 54, $\mathrm{n}^{\mathrm{o}}$ 2, jan. 2002, pp. 245-276.

95 Cf. José Luiz Quadros Magalhães, Pacto Federativo, José Luiz Quadros Magalhães (coord.), Belo Horizonte, Mandamentos, 2000, pp. 13-14.
} 
"tentativa, nem sempre bem sucedida, de reduzir a fragmentação, e de aumentar a densidade e a coesão do processo político, em torno de interesses mais homogêneos. $\mathrm{O}$ paradoxal, no entanto, é que quanto maior a homogeneidade, maior também é a hostilidade a qualquer diferença, por menor que seja, o que conduz à exacerbação dos conflitos particularistas" $" 96$.

Demonstra ser fortemente aconselhável a fuga de qualquer esquema federalista que, tomando como dogma o postulado da isonomia entre os entes federados, intente congregar de modo superficial partes muito diversificadas. Também não é indicado aplicar a descentralização política que marca o Estado federal em países que tenham como característica a presença de unidades subnacionais extremamente assemelhadas, haja vista que, nesse caso, a intolerância com o que diferir do conjunto impedirá a formação de laços associativos consistentes e operativos. Percebe-se, então, que a diversidade sempre presente nos cenários federativos, além de significar a própria razão de ser dessa forma de organização estatal, demanda vigília permanente, pois poderá ser igualmente utilizada para encorpar aspirações secessionistas voltadas a colocar termo a Estados federais desprovidos de bases sólidas.

Em resumo, temos que a desconsideração dos desníveis regionais que naturalmente dimanam das unidades do Estado denota esquecimento de lições primárias do ideário federalista. Equivale a fazer tabula rasa da orientação, manifestada no Brasil com absoluta precisão em 1902 por ALFREDO VARELA, de que "o regime federativo tem a aplicação em sociedades cujas diferentes partes não marchem no mesmo sentido, ou com a mesma velocidade, caso em que se incumbe a um governo central a função de presidir e coordenar todas as tendências convergentes da mesma sociedade, respeitando suas divergências legítimas, que passam a ser atendidas pelos governos locais das várias regiões em que se divide o poder do país respectivo" $"$.

\footnotetext{
${ }^{96}$ A Reforma-Mater: Os Riscos (e os Custos) do Federalismo Incompleto, in Parcerias Estratégicas, $\mathrm{n}^{\circ}$ 6, mar. 1999, pp. 93-94. No mesmo sentido, BRUNO THÉRET, estatui que "um 'verdadeiro' sistema federal pode, assim, ser definido como aquele em que se institui um mecanismo de auto-observação do princípio federativo, quer dizer, aquele no qual há um equilíbrio relativo da contradição constitutiva entre unidade e diversidade: caso a unidade triunfe sobre a diversidade, ou se, ao contrário, a diversidade triunfar sobre a unidade, não mais se pode falar de federalismo. Isto fica evidente no segundo caso, que implica uma pulverização explícita da federação; se dá menos no primeiro, pelo fato de que em geral continuamos falando de Estado federal, mesmo quando não existe mais, de fato, o sistema federal, mas apenas um Estdo unitário descentralizado", O Federalismo como Princípio de Regulação do Regionalismo. Uma Análise dos Programas de Perequação Destinados a Compensar as Desigualdades Inter-regionais na América do Norte (Canadá-EUA), in Contexto Internacional, vol. 20, nº 1, p. 110.

${ }^{97}$ Direito Constitucional Brasileiro: Reforma das Instituições Nacionais, $2^{\mathrm{a}}$ ed., Rio de Janeiro, Livraria H Garnier, 1902, p. 42.
} 


\section{I.5. O Infundado Risco da Secessão nos Estados Federais Assimétricos}

Embora existam fortes razões que aconselhem adotar técnica da assimetria em Estados compostos que utilizam o texto constitucional para congregar regiões marcadas por impactantes heterogeneidades e desníveis estruturais, é perigoso creditar unicamente aos arranjos assimétricos a solução duradora e definitiva dos problemas sofridos por essas organizações estatais. É imperioso ressaltar a imprescindibilidade de fazer com que tais instrumentos de diferenciação estejam acompanhados de consistentes estudos sobre quais aspectos conformadores do Estado exigem reparos do constituinte, caso contrário o federalismo assimétrico perderia completamente toda a credibilidade que hoje detém junto àqueles que se dedicam ao estudo dessa forma de Estado.

Ademais também é esperado que as várias unidades políticas da Federação desenvolvam a consciência de que a assimetria não significa, sob nenhum prisma, a concessão de privilégios ou de preferências em favor de entes específicos. Cabe, portanto, impregnar no tecido federativo a mentalidade de que as assimetrias somente são adotadas porque a diversidade regional demonstrou ser um fator que, caso não fosse satisfatoriamente acomodado, certamente implicaria no insucesso de qualquer pacto federativo. Tratar com a especificidade devida uma unidade federada (ou um grupo delas) que destoa do conjunto por características que lhe são próprias, ao que tudo indica, parece ser a solução para garantir a coexistência pacífica de todas as peças que compõem o cenário federativo.

Nessa toada, fica claro que a manipulação desastrosa das ferramentas de materialização da assimetria pode levar ao definitivo esvaziamento de qualquer pretensão de unidade do Estado. Forças centrífugas certamente ganharão contornos visíveis, em virtude da falta de harmonia entre múltiplas realidades da Federação, e tal quadro influenciará não apenas o fracasso de políticas públicas que demandarem expressiva cooperação intergovernamental, como também irá esgarçar os laços federativos, podendo, em situações extremas, dar ensejo ao surgimento de temidas aspirações de cunho secessionista.

Não é sem motivo que, diante do perigo que advém de experiências de assimetria federativa implantadas de forma inconsequente, JAVIER GARCÍA ROCA pontua que "um federalismo fundado nas desigualdades - fáticas e normativas - entre os entes territoriais pode trazer sérios problemas de coesão social e de governabilidade, pois determinados graus de assimetria ou heterogeneidade podem dar ensejo ao estabelecimento de 
privilégios ou discriminações, impedindo-se, consequentemente, que se alcance a desejável uniformidade substancial das condições de vida dos cidadãos, o que representa o objetivo irrenunciável de qualquer Estado com traços associativos, porque não dizer de todos os Estados"98.

A determinação de competências e poderes assimétricos aos entes políticos deve, obrigatoriamente, ocorrer de modo controlado, razoável e somente dentro de limites aceitáveis de conformação constitucional, haja vista a assimetria estabelecida descompromissadamente pode ocasionar o desencadeamento da situação mais temida por qualquer Federação: seu desmantelamento. WILL KYMLICKA demonstra comungar desse posicionamento ao enfatizar expressamente que "o perigo da assimetria está em eventualmente conduzir os territórios autônomos à secessão" "99. A possibilidade de ser a secessão influenciada pela assimetria também preocupa STÉPHANE DION, a qual, entende que o federalismo assimétrico deve ser instituído com muita cautela, porque, na sua percepção, "a assimetria extremada corresponderia a uma antessala do separatismo"100.

Em que pese o perigo da fragmentação de Estados federais estruturados a partir de esquemas assimétricos mal-elaborados e precários, a ocorrência desse evento representa hipótese excepcional. Sem dúvida, não é o simples fato de uma Federação ter adotado elementos de assimetria em sua estrutura que provocará o incontrolável desencadeamento de impulsos de fragmentação de seu território, mas sim o emprego inadequado do federalismo assimétrico que ocasionará a frustração de qualquer medida tomada para a pacificação de eventuais conflitos interregionais que podem ter sua causa na disparidade dos entes federados.

Os insucessos resultantes da inobservância dos valores básicos que orientam a teoria do federalismo assimétrico não podem ser tomados como suporte para desabonar essa importante ferramenta disponibilizada ao regime federativo. Sufragar, de plano, o entendimento de que o federalismo assimétrico equivale a um primeiro passo rumo à secessão significa evidente menosprezo à capacidade integrativa das Constituições elaboradas com base em paradigmas apresentados pela engenharia constitucional. Nesse diapasão, considera ESTHER SEIJAS VILLADANGOS que os textos constitucionais

\footnotetext{
${ }^{98}$ España asimétrica (Descentralización territorial y asimetrías autonômicas: una especulación teórica), in Asimetría y Cohesión en el Estado Autonómico: Jornadas sobre el Estado Autonómico: Integración y Eficacia, INAP (Instituto Nacional de Administración Pública), Ob. cit., p. 60.

${ }_{99}$ Federalism, Nationalism and Multiculturalism, in Theories of Federalism: A Reader, Dimitrios Karmis e Wayne Normann (eds.), New York, Palgrave Macmillan, 2005, p. 283.

100 El Federalismo Fuertemente Asimétrico: Improbable e Indeseable, in Asimetría Federal y Estado Plurinacional: El Debate sobre la Acomodación de la Diversidad en Canadá, Bélgica y España, Enric Fossas e Ferran Requejo (eds.), Ob. cit., p. 210.
} 
contemporâneos cada vez mais estão sintonizados com a necessidade de compatibilizar diferenças intra e interregionais, na medida em que se valem de sistemas específicos de repartição de competência e de formas originais e eficientes de cooperação e coordenação federativa $^{101}$.

De fato, deixar de acomodar as disparidades internas que interferem diretamente no funcionamento das Federações importa em risco muito maior à coesão e à integridade federativa do que acreditar em meras suposições que não se coadunam com a essência do espírito associativo que, em geral, rege os Estados federais. Não se vê, assim, risco de desintegração em todos os Estados federais assimétricos, e, sobretudo naqueles cujo pacto federativo apresenta fundamentos consistentes, tal possibilidade é sempre desprezível. Por tal razão, mesmo sendo o federalismo assimétrico uma aposta feita na força integradora das Constituições, não há o porquê acreditar que ele, invariavelmente, daria ensejo para o fim da Federação.

Assim, conclui-se que o ponto que confere credibilidade às propostas de diferenciação jurídica das unidades autônomas é exatamente a constatação de que "o princípio da paridade dos Estados-membros sufoca a virtude do federalismo - a unidade na diversidade -, estabelecendo uma absurda e injusta identidade na diversidade", conforme enuncia MANOEL GonÇALVES FERREIRA FILHO ${ }^{102}$. Sem dúvida, a racionalidade que informa o funcionamento do Estado federal requer, em essência, que as instituições políticas subnacionais sejam o mais possível adaptadas às verdadeiras condições regionais, sendo defeso estabelecer rigorismos formais que conduzam à inflexível padronização dos entes criados. É evidente, desse modo, que "regiões com grande desnível de desenvolvimento econômico, com não menor desnível de desenvolvimento econômico, com não menor desnível de desenvolvimento social e cultura política, com imensa disparidade de densidade demográfica, não podem gozar das mesmas competências, contar com iguais poderes, com as mesmas fontes de renda" ${ }^{\prime 103}$.

Espera-se que os recursos inerentes à assimetria federativa sirvam para permitir que a descentralização política não venha a ser apenas um fator que beneficie alguns dos integrantes da Federação. Essa variante do fenômeno federativo prima, por excelência, pelo resguardo de todos os interesses regionais, independentemente da especificidade e da inconstância dos mesmos, além de apresentar-se como interessante ferramenta de combate

\footnotetext{
${ }^{101}$ Cf. Ob. cit., p. 219.

${ }^{102}$ A Democracia Possível, $2^{\mathrm{a}}$ ed., São Paulo, Saraiva, 1974, p. 112.

${ }^{103}$ Manoel Gonçalves Ferreira Filho, A Democracia Possível, Ob. cit., p. 112.
} 
à tradição obsoleta de consagrar a ficção da igualdade inflexível entre os entes federados. A observância de tais diretrizes confirma o compromisso de, com o Estado federal, permitir e incentivar o florescimento da democracia, haja vista que se enaltece abertamente o dever de respeito à diversidade, aqui revelada em aspectos territoriais.

Em última análise, o federalismo assimétrico proporciona o encorajamento para a tomada de decisões políticas voltadas a estabelecer, entre as regiões, pacificação institucional, neutralizando-se os efeitos perversos das desigualdades apuradas como fatores de limitação do desenvolvimento nacional. Como defendido, a igualdade de oportunidades econômicas, a equalização das condições de vida da população e o sucesso na execução de programas sociais intergovernamentais exigem, se for o caso, que se implantem instrumentos de diferenciação entre as partes federadas. E, com incontrastável propriedade, caberá ao Estado federal assimétrico calibrar as heterogeneidades regionais mediante o emprego de eficientes arranjos jurídicos que tenham os entes federados como foco. 


\title{
II. EMERGÊNCIA HISTÓRICA E AFIRMAÇÃO INSTITUCIONAL DO FEDERALISMO ASSIMÉTRICO
}

\begin{abstract}
"Urge, pois, abrir mão de certas velharias inseridas na Constituição que confundem a Federação com um mecanismo de convivência de estados carentes de unidade nacional para abraçar a Federação como instrumento da democracia".
\end{abstract}

CELSO BASTOS ${ }^{104}$

\section{II.1. O Estado Federal no Contexto do Pós-Segunda Guerra Mundial}

O surgimento da ideia de assimetria aplicada ao universo dos sistemas federativos encontra franca influência na identificação do quadro descrito por M. MOUSKELI, consubstanciado na verificação de que "houve, no pós-guerra, o surgimento de vários novos Estados federais; bem como a transformação dos antigos. Nestes últimos Estados, o federalismo tem apresentado aspectos sensivelmente diferentes dos que estávamos acostumados a ver no passado. Fala-se já na transformação do federalismo, do fracasso das teorias clássicas e do advento do federalismo racionalizado" ${ }^{105}$. O federalismo, de fato, tal qual se apresenta na atualidade denota evidente aperfeiçoamento; os traços distintivos que o definiam no século XVIII, quando o regime federativo foi idealizado e colocado em prática nos Estados Unidos, sofreram significativas alterações, e a assimetria, por excelência, comprova esse dado.

Consoante o afirmado, as maiores mudanças ocorreram após o ano de 1945, período em que os impactos ressoados no terreno da elaboração de fórmulas políticoconstitucionais que estruturam os Estados federais começaram a ser admitidos como elementos responsáveis pelo sucesso do pacto federativo estabelecido. $\mathrm{O}$ preciso diagnóstico das causas que dinamizaram a adoção de novos paradigmas ao sistema federativo é ofertado por R. MichAEL StEvEns, que entreviu, nos eventos sucedidos a partir dessa época, uma nova etapa para o funcionamento das organizações estatais compostas. A multiplicidade de Estados existentes passou a exigir constantes inovações e releituras de institutos já consagrados, a fim de que fosse possível compatibilizar os

${ }^{104}$ A Federação no Brasil, Ob. cit., p. 2.

${ }^{105}$ Cf. Teoria Jurídica del Estado Federal, México D.F., Editora Nacional, 1981, p. 131. Consultar também Gumersindo TrujlLlo, Integración Constitucional de los Hechos Diferenciales y Preservación de la Cohesión del Estado Autonômico, in Asimetría y Cohesión en el Estado Autonómico: Jornadas sobre el Estado Autonómico: Integración y Eficacia, INAP (Instituto Nacional de Administración Pública), Ob. cit., pp. 21-25. 
inúmeros contextos que reclamavam soluções factíveis acerca da racionalização da distribuição territorial do poder político ${ }^{106}$.

Assinala o estudioso, com base em registros datados de 1977, que "o mais sensível aspecto desse novo período foi a proliferação de novos Estados resultantes da fragmentação dos grandes impérios do século XIX. Da conquista da independência do Líbano em 1943 até a conclusão da independência do Suriname em 1976, 85 novos Estados-nação foram formados, ou seja, metade dos aproximadamente 158 Estados-nação atualmente existentes representa, de alguma forma, consequência do pós-guerra" ${ }^{\text {"107 }}$. Com efeito, esse surgimento exponencial de Estados trouxe, como consequências diretas, o imperativo de flexibilização dos comandos informadores da Federação e a necessidade de criarem-se novas formas de manifestação do fenômeno da descentralização políticoterritorial do poder.

Decisivamente, o panorama retratado contribuiu para o acatamento da diretiva de conformar harmonicamente os multifacetados desníveis verificados entres as unidades integrantes das Federações, utilizando-se, para tanto, de instrumentos jurídicos idealizados para servir como mecanismos compensatórios das disparidades identificadas ${ }^{108}$. A tese do federalismo assimétrico, aos poucos, deixou de figurar apenas nos estudos e nas investigações acadêmicas para começar a ser aplicada à realidade dos Estados, onde o compartilhamento do poder assumiu a feição de peça fundamental e insubstituível no processo de arquitetura dos órgãos estatais que pretendiam ser eficientes. A assimetria foi considerada instrumento de penhor da pacificação de diferenças inter-regionais conflituosas (algumas delas, até então, consideradas incontornáveis), ao passo que tornou possível acomodar problemáticas divergências e pontos de tensão entre as unidades federadas.

Conforme atesta ENRIC FOSSAS, o debate sobre a assimetria reporta a um tema sempre atual nas Federações, qual seja, a fórmula jurídica para alcançar a unidade do Estado, cuidando-se para que os arranjos político-constitucionais não representem ultraje à

\footnotetext{
${ }^{106}$ Cf. Asymmetrical Federalism: The Federal Principle and The Survival of the Small Republic, in Publius, 7:4, Fall 1977, p. 179.

${ }^{107}$ Idem, Ibidem.

${ }^{108}$ Pactuam do mesmo entendimento Ursula K. Hicks, Federalism: Failure and Sucess, New York, Oxford University Press, 1978, p. 172; e CeZAR SALDANHA SouzA Junior, Estudo Introdutório: Em Torno do Sentido do Federalismo, in Direito do Estado - Estudos sobre Federalismo, Cezar Saldanha Souza Junior e Marta Marques Avila (coord.), Ob. cit., pp. 27-28.
} 
diversidade das partes federadas ${ }^{109}$. Nesse campo, coube a CHARLES D. TARLTON suscitar, no ano de 1965, a importância de submeter os regimes federativos a uma interpretação que tome como base a combinação de fatores históricos, sociais, políticos, econômicos e culturais que, quando conjugados no plano da realidade, conduzem a variados modos de conexão entre as unidades autônomas e o Estado federal ${ }^{110}$. Assim, quanto maior forem as disparidades regionais, mais indicada é a aplicação de técnicas relacionadas com a assimetria federativa.

De fato, muito antes desse período de expansão das reflexões em torno do federalismo assimétrico, a ideia de igualdade entre os entes federados já constituía aspecto abordado nos discursos constituintes e governamentais das várias Federações do mundo ${ }^{111}$. Entretanto, o que se verifica é que as preocupações dessa ordem não resultavam em arranjos juridicamente diferenciados para a compensação dos problemáticos desníveis territoriais, uma vez que era recorrente adotar a premissa de que todas as unidades deveriam receber idêntica parcela de autonomia, sendo irrelevantes os pontos que as distinguiam. A publicação por TARLTON do famoso artigo "Symmetry and Asymmetry as Elements of Federalism: a Theoretical Speculation" representou não apenas uma nova perspectiva de análise das diversidades sob o prisma da política, mas certamente também foi responsável por despertar o interesse do constitucionalismo contemporâneo para a necessidade de repensar as múltiplas implicações decorrentes da compatibilização das diferenças factuais que influem grandemente na configuração do pacto federativo.

Ao assumir progressiva proeminência, a noção de assimetria foi incluída de forma permanente na pauta do Direito Constitucional, sendo estudada principalmente por aqueles que abraçaram a tarefa de redesenhar as instituições políticas já consagradas pelo constitucionalismo a fim de adaptá-las aos noveis paradigmas do Estado. A sedimentação

${ }^{109}$ Cf. Asimetría y Plurinacionalidad en el Estado Autonômico, in Asimetría Federal y Estado Plurinacional: El Debate sobre la Acomodación de la Diversidad en Canadá, Bélgica y España, Enric Fossas e Ferran Requejo (eds.), Ob. cit., p. 280.

${ }^{110}$ Cf. Ob. cit., p. 861.

111 ENRIC FOSSAS confirma essa afirmação ao expender que "na Convenção de Filadélfia foi rechaçada a admissão de novos membros em pé de igualdade (Madison, 1908, II, 89), embora com o passar dos tempos a Suprema Corte dos Estados Unidos afirmou o princípio da igualdade dos Estados 'em poder, dignidade e autoridade' (Coyle v. Oklahoma [1911], 221 US 559, 576). Essa problemática foi enfrentada ainda na Alemanha, durante a vigência da Constituição Imperial de 1871, ocasião em que a dogmática juspublicista aventou a possibilidade de acordar direitos particulares (jura singularia) a determinados Estados (Baviera, Prússia) em relação com o conjunto (Laband, 1900, I, 185). Entretanto, em nenhum desses registros existe referência direta à assimetria conjugada à pluralidade. A novidade das discussões relacionadas à assimetria na Espanha (ou Canadá) está precisamente na mencionada conexão entre a organização político-jurídica e a questão nacional, o que situou a Constituição no centro de toda essa polêmica", Asimetría y Plurinacionalidad en el Estado Autonômico, in Asimetría Federal y Estado Plurinacional: El Debate sobre la Acomodación de la Diversidad en Canadá, Bélgica y España, Enric Fossas e Ferran Requejo (eds.), Ob. cit., pp. 280-281. 
do entendimento de que a Constituição Federal deve refletir com fidelidade o compromisso de edificar organizações estatais prontas para administrar os complexos ambientes sociais encontrados na contemporaneidade levou ao abandono da inflexível orientação de estrita igualdade formal dos entes autônomos situados num mesmo patamar governamental. A ficção de que os componentes do concerto federativo seriam simétricos - e, em virtude disso, necessitariam de idêntico tratamento - perdeu espaço para a ordem de compatibilizar a desigualdade.

A consequência desse processo foi o reconhecimento da importância de, no plano da realidade, concretizar-se a formulação teórica de que o texto constitucional deve sempre representar a ordem fundamental jurídica da coletividade ${ }^{112}$. A tendência de empregar o Direito e as instituições jurídicas como instrumentos habilitados a harmonizar as diversidades regionais, em especial aquelas que poderiam figurar como elementos desintegradores, foi decisivamente realçada com o advento da vertente assimétrica do Estado. Essa é, como se percebe, a principal proposta que motiva o contínuo aperfeiçoamento das estruturas federativas ligadas ao universo da assimetria.

Não é descabido sublinhar que, nos primórdios do federalismo, JOHN JAY já advertia sobre os perigos que podem acompanhar um Estado territorialmente composto sustentado por inconsistentes laços associativos. Enunciou, no século XVIII, que "a fraqueza e a desunião internas favorecerão a aumento dos perigos externos; e que nada mais tende a proteger-nos contra eles do que dispormos de união, poder e um bom governo" $" 113$. Embora esses comentários enfatizem questões relacionadas à política externa (motivo justificado porque o federalismo nos Estados Unidos surgiu como resposta ao desafio de permitir que as antigas colônias inglesas vivessem como Estados livres e, ao mesmo tempo, unidas para garantir a permanência da liberdade há pouco conquistada por meio da Guerra de Independência), vale utilizá-los como norte para evitar a desarticulação entre as unidades do conjunto. Transpondo-as para o âmbito interno, fica claro que a existência de um governo central insensível às exigências das partes que o compõem dificilmente permitirá a formação de um vigoroso sentimento de lealdade federativa, podendo ainda, no extremo, ensejar traumáticos processos de fragmentação do território ${ }^{114}$.

${ }^{112}$ Cf. KonRAd HeSSE, Elementos de Direito Constitucional da República Federal da Alemanha, Ob. cit., p. 37.

${ }^{113}$ Cf. AleXander Hamilton, James Madison e John Jay, Ob. cit., p. 119.

${ }^{114}$ Pontua YvES LeJEUNE que o princípio da lealdade federativa deve ser observado tanto pela União como pelos demais entes subnacionais, exigindo que se estabeleçam padrões no seio do Estado composto que levem a um comportamento autenticamente federalista. Uma vez materializada a lealdade, o federalismo importará não somente na colaboração de cada unidade com o governo central, mas também que este aceite 
Ademais, interessa fazer referência à compreensão de DESIDERIO FERNÁNDEZ MANJÓN que entende ser possível traduzir a assimetria em "multiplicidade de poderes, não necessariamente iguais em termos de competências, nem exercidos sobre territórios homogêneos em extensão, população, fatores étnicos, etc., mas todos eles submetidos ao princípio da legalidade e dotados de legitimidade democrática obtida da base social devida" $" 115$. O substrato legitimador precisa ter identidade com a própria Constituição, já que esse documento jurídico abarca, por excelência, o conjunto de normas que traçam o modo de funcionamento e os fins buscados pelos órgãos estatais instituídos pelo Estado federal para viabilizar a descentralização política ${ }^{116}$. Dessa forma é que, ao se voltar as atenções para a legitimidade constitucional, o terreno da íntima relação entre a evolução do constitucionalismo - que se rende cada vez mais à influência do Estado Social-e a adoção de mecanismos institucionais assimétricos nas Federações do mundo acaba sendo descoberto. E é exatamente isso que será analisado a seguir.

\section{II.1.1. O Estado Social e as Federações Assimétricas}

A preocupação constitucional com as diferenças territoriais expressadas por inúmeras variantes permitiu que se alcançasse unidade política em vários Estados federais que sofriam com delicados conflitos internos. Aos poucos foram superados pactos federativos meramente formais desprovidos de substância que não garantiam a efetivação de uma soldagem vigorosa entre seus entes. Também se tomou consciência de que as relações recíprocas estabelecidas entre as unidades da Federação não podiam estar fundadas em rigorosos juízos de padronização, o que sempre levava à desconsideração das demandas e das singularidades regionais. A assimetria federativa plasmada sob os mais diversos enfoques nas Constituições do mundo representa, pois, o resultado da percepção de que diversidade precisa ser preservada e, ao mesmo tempo, utilizada como elemento de promoção da eficiência governamental ${ }^{117}$.

Com efeito, o fato de o Estado ter assumido o caráter de agente promotor de inclusão e de pacificação social determinou a concretização da tendência de visualizar, nas

as regras da boa convivência política, Cf. El Federalismo en Bélgica, in Asimetría Federal y Estado Plurinacional: El Debate sobre la Acomodación de la Diversidad en Canadá, Bélgica y España, Enric Fossas e Ferran Requejo (eds.), Ob. cit., pp. 230-231.

${ }^{115}$ Desafios de la Diversidad Territorial en los Estados Compuestos Asimétricos, Ob. cit., p. 147.

${ }^{116}$ Cf. J. H. MEIRELles TEIXEIRA, Ob. cit, p. 3.

117 Cf. Desiderio Fernández Manjón, Desafios de la Diversidad Territorial en los Estados Compuestos Asimétricos, Ob. cit., p. 147. 
disposições encartadas nas Constituições, verdadeiras promessas para o enfrentamento daquelas desigualdades há muito conhecidas e que se apresentavam como prejudiciais à coesão do Estado federal. Tal entendimento ganhou notável expressividade nas democracias contemporâneas, sobretudo porque os valores político-jurídicos consignados nos textos constitucionais, confeccionados nas últimas décadas, adquiriram novos contornos. Sob os influxos dessa nova ambientação, alguns nortes principiológicos adquiriram grande relevância para a interpretação do sistema de distribuição de competências federativas, a exemplo da ordem de promover a democracia, de efetivar os direitos fundamentais e de os agentes públicos tratar com seriedade as incumbências que lhe são constitucionalmente traçadas ${ }^{118}$.

As mudanças aludidas decorrem essencialmente das reformas sociais ocorridas em muitos Estados na segunda metade do século XX, sobretudo nos países da Europa continental, que se alinharam aos comandos ventilados pelo regime social-democrático ${ }^{119}$. Esse fenômeno desencadeou ainda o advento do Estado de Bem-Estar Social (Welfare State), que interferiu intensamente na Federação, na medida em que fez surgir o denominado federalismo cooperativo. Essa configuração do Estado federal trouxe como marca inconfundível a prática de permanentes relações intergovernamentais entre o poder central e as unidades federadas, ou ainda apenas entre as partes periféricas do conjunto federativo $^{120}$, o que evidentemente contribuiu para a decantação do ideal de equilíbrio federal em função da interdependência e da colaboração entre os diferentes níveis de poder.

A cooperação, tal qual registra ENOCH ALBERTI ROVIRA, pressupõe a compreensão de que o governo central e os governos periféricos não são estranhos entre si, devendo todos mover-se em campos de atuação separados e acordados, num constante trabalho conjunto para o alcance de interesses comuns, em especial para buscar soluções para problemas que demandam a soma de esforços ${ }^{121}$. Ao fincar bases sólidas no terreno do

\footnotetext{
118 Cf. AnA PAula De BARCEllos, Controle Social, Informação e Estado Federal: A Interpretação das Competências Político-Administrativas Comuns, in Vinte Anos da Constituição Federal de 1988, Cláudio Pereira de Souza Neto, Daniel Sarmento e Gustavo Binenbojm (coord.), Rio de Janeiro, Lumen Juris, 2009, p. 633.

${ }^{119}$ Acerca do aparecimento da democracia social no período posterior à Segunda Guerra, ver JOSÉ REINALDO LIMA LOPES, Direito e Transformação Social: Ensaio Interdisciplinar das Mudanças do Direito, Belo Horizonte, Nova Alvorada, 1997, p. 80.

${ }^{120} \mathrm{O}$ incremento progressivo das relações intergovernamentais empreendidas pelas partes integrantes do conjunto federativo, sem participação da União, é pontuado por DAVID C. NICE, Federalism: The Politics of Intergovernamental Relations, New York, St. Martin's Press, 1987, p. 115.

${ }^{121}$ El Federalismo Actual como Federalismo Cooperativo, in Revista Mexicana de Sociología, vol. 58, no 4, oct./dec., 1996, p. 52.
} 
Estado Federal, a cooperação exigiu a redefinição da noção de autonomia. Perdeu-se a crença de que o federalismo, pelo simples fato de ser utilizado em um determinado Estado, conseguiria automaticamente exercitar a capacidade de articular a unidade política entre o todo.

Desde então, os questionamentos sobre a Federação passaram a tratar das reivindicações e das exigências advindas das diferentes realidades socioeconômicas, históricas e culturais conviventes em algumas sociedades, o que foi notadamente potencializado pelo solidarismo que se arraigou a muitas estruturas federativas. $\mathrm{O}$ isolamento e o distanciamento entre os entes federados foram substituídos pela interdependência entre esses atores na condução dos programas de atuação estatal ${ }^{122}$. A máxima preconizada por CÁRMEN LÚCIA ANTUNES ROCHA, de que, "para serem fortes, os Estados precisam ser legítimos, o que não pode prescindir de acatamento e respeito às desigualdades regionais, às demandas de todos os cidadãos que fazem parte dos seus respectivos povos" ${ }^{\prime 23}$, assumiu a posição de norte condutor de muitas das Federações redesenhadas.

Aos governos foi colocada a ordem de que a legitimação e o acerto de suas ações passariam invariavelmente pela observância do comando de que "o poder apenas se justifica ex parte populi, não mais ex parte principi" ${ }^{\text {"124 }}$. Tal diretriz redundou em significativas alterações nas estruturas políticas dos Estados, uma vez que foi preciso abandonar os dogmas do liberalismo - tão caros e influentes nas etapas de criação e de aplicação das Constituições anteriores - e adotar horizontes mais alargados, em que os ideais de igualitarismo e de equalização econômica e de oportunidades gozassem de amplo prestígio $^{125}$. Por óbvio, o federalismo não ficou imune a essas relevantes transformações, e a cooperação federativa responde pelas principais transformações ocorridas nessa forma de Estado.

Para adaptar-se aos postulados do Estado Social, a Federação foi submetida a sensíveis mudanças estruturais, as quais tiveram como maior expoente a institucionalização de uma consistente teia de relacionamentos abrangendo os integrantes do ambiente federativo. Ao lado do estabelecimento de competências diferenciadas para

${ }^{122}$ Cf. TÉRCIO SAMPAIO FerRAZ Junior, Litígio Constitucional entre Estados-membros e a Competência do STF, in Revista de Direito Administrativo, no 194, out./dez. 1993, Rio de Janeiro, p. 6.

${ }^{123}$ República e Federação no Brasil: Traços Constitucionais da Organização Política Brasileira, Belo Horizonte, Del Rey, 1996, p. 257.

${ }^{124}$ José Augusto Lindgren Alves, Os Direitos Humanos como Tema Global, São Paulo, Perspectiva, 2007, p. 43.

${ }^{125}$ Cf. EnIo Moraes da Silva, O Estado Democrático de Direito, Revista de Informação Legislativa, Brasília, ano 42, nº 167, jul./set. 2005, p. 222. 
determinados entes federados (pautadas geralmente pelo estágio de desenvolvimento apresentado e por questões de natureza histórica, étnica e cultural), as interações intergovernamentais mostraram ser um eficiente engenho para a superação das disparidades territoriais com vistas a acomodar as drásticas heterogeneidades existentes. $\mathrm{O}$ poder central, antes apartado das condições apresentadas pelas unidades federadas, começou a ter de conhecer com profundidade a diversidade enredada nos territórios de cada uma das regiões, caso contrário não teria condições de vivificar plenamente o princípio da solidariedade ${ }^{126}$.

Em verdade, esse referido impulso cooperativo determinou uma nova configuração do Estado federal, na medida em que sintonizou o federalismo aos valores propagados pela democracia social ${ }^{127}$. Conforme observa FERRAN REQUEJO, a complexidade da vida no interior dos Estados compostos, por refletir cada vez mais o pluralismo da sociedade, requer maior dinamismo e ininterrupto aprimoramento dos acordos celebrados pelas partes componentes dos mesmos. Como consequência da intensa e rápida transformação da realidade, percebe-se que, nesses contextos, o êxito do federalismo requer arranjos cooperativos que atendam às várias exigências colocadas ao poder estatal organizado e que, sem dúvida, os acordos intergovernamentais, porque comportam potencial flexibilidade, conseguem ser adaptados com facilidade às realidades específicas que disciplinam $^{128}$.

Nessa toada, observa-se ainda que, nos últimos tempos, novos acordos federativos enaltecedores do desenvolvimento regional têm sido empreendidos por Estados federais do mundo todo, o que lhe faz prenunciar que "existem razões para esperar que, na pósmodernidade, novas aplicações do princípio federativo sejam desenvolvidas, agregando-as aos esquemas de ordenação do poder já conhecidos hoje" ${ }^{2129}$. Dentre esses arranjos, tornamse visíveis os esforços governamentais comuns voltados a implementar ações ligadas à

\footnotetext{
${ }^{126}$ Sobre esse ponto, ao analisar a realidade brasileira, RUI DE BRITTO ÁLVARES AFFONSO anotou que, na compreensão dos mecanismos de distribuição de competências, de divisão dos gastos de cada esfera de governo e do formato das transferências entre elas, "não cabe partir de qualquer divisão ideal de responsabilidades ancorada em alguma lógica apriorística, mas apreender o significado dessas questões em um país continental, com enormes disparidades regionais, bem como considerar o papel que os fundos públicos desempenham nas alianças políticas. Inicialmente, é importante destacar que a heterogeneidade estrutural do País dificulta a adoção de qualquer divisão estrita e permanente de competências ou encargos", A Federação no Brasil, in A Federação em Perspectiva: Ensaios Selecionados, Rui de Britto Álvares Affonso e Pedro Luiz Barros Silva (org.), São Paulo, FUNDAP, 1995, p. 69.

127 Cf. Daniela Bifulco, Cittadinanza Sociale, Egualianza e Forma di Stato, in I Diritti Sociali tra Regionalismo e Prospettive Federali, Lorenzo Chieffi (org.), Padova, CEDAM, 1999, p. 44.

${ }^{128}$ Cf. La Acomodación 'Federal' de la Plurinacionalidad. Democracia Liberal y Federalismo Plural en España, in Asimetría Federal y Estado Plurinacional: El Debate sobre la Acomodación de la Diversidad en Canadá, Bélgica y España, Enric Fossas e Ferran Requejo (eds.), Ob. cit., pp. 330-331.

${ }^{129}$ DANIEL J. ElAZAR, Exploring Federalism, Tuscaloosa, The University of Alabama Press, 1987, p. 8.
} 
concretização de direitos de índole social, a exemplo do direito à saúde e do direito à educação. Ellis KATZ e G. AllAN TARR confirmam tal tendência, os quais pontuam que a "proliferação de arranjos federativos é largamente influenciada pela preocupação com direitos - mais especificamente, pelos esforços direcionados a acomodar direitos reclamados pelos diversos grupos que vivem em Estados consolidados"130.

De acordo com os moldes da democracia social, a justificativa primeira que deve reger a estruturação do Estado - o que se estende, inclusive, à opção de adotar o federalismo - será a necessidade de efetivar os direitos fundamentais em sua integralidade. Essa percepção é ilustrada por PAULO BONAVIDES, que entende ter essa vertente do regime democrático ocasionado a renovação dos aparatos governamentais por meio do surgimento de um quadro em que "o Estado-inimigo cedeu lugar ao Estado-amigo, o Estado-medo ao Estado-confiança, o Estado-hostilidade ao Estado-segurança. As Constituições tendem assim a se transformar num pacto de garantia social, num seguro com que o Estado administra a Sociedade"131 . A articulação política entre as diferentes esferas autônomas da Federação, bem como a coesão e a efetividade das relações intergovernamentais por elas estabelecidas, fizeram com que as peculiaridades impregnadas a cada uma delas adquirissem amplo destaque e, por conta disso, passassem a ser admitidas no processo de formulação de políticas de cooperação.

É interessante anotar que as considerações de MANUEL GARCIA-PELAYO confirmam o exposto até aqui, sobretudo ao se verificar que, nos termos defendido por esse autor, a configuração do Estado Social transformou a organização estatal em uma estrutura predominantemente administrativa, voltada ao cumprimento do vasto catálogo de deveres prestacionais colocados aos governos constituídos. Dentre as características mais salientes dessa configuração do Estado, está a fusão da racionalidade política, da racionalidade administrativa e da racionalidade sócioeconômica para a elaboração de estruturas políticoadministrativas que sejam eficientes e que possam viabilizar a justiça distributiva apregoada por tal feição do Estado. A soma das profundas mudanças estruturais realizada desembocam na reelaboração dos instrumentos de atuação administrativa do poder político, fazendo-os com que sejam uma estrutura desenvolvida e flexível, de complexo funcionamento, mas capacitada a responder satisfatoriamente as demandas que lhe são

${ }^{130}$ Federalism and Rigths, Ellis Katz e G. Allan Tarr (eds.), Boston, Rowman \& Littlefield Publishers, 1996, p. XV.

${ }^{131}$ Curso de Direito Constitucional, $18^{\text {a }}$ ed., São Paulo, Malheiros, 2006, p. 380. 
postas pelos diferentes setores da sociedade, inclusive pelos diversos entes autonômos do Estado territorial composto ${ }^{132}$.

Decorre, portanto, da afirmação institucional desse paradigma de Estado democrático a tendência de estampar, nos textos constitucionais, preocupações acerca da compatibilização da diversidade reinante no meio social que, em muitos casos, era tida como fator preponderante do fracasso de ações governamentais integradas. Percebeu-se que desconsiderar as especificidades apresentadas pelas diversas partes da Federação poderia significar a assunção do risco de insucesso das múltiplas relações intergovernamentais celebradas, dada a importância de aferir as reais possibilidades de implementação dos direitos sociais pelos entes federados, considerados cada qual em sua singularidade. A correta fixação de encargos e das incumbências a serem suportados pelos distintos níveis de governo tornou-se, de fato, um ponto inafastável das experiências bemsucedidas de federalismo cooperativo, uma vez que demonstram ser absurdo flagrante que os acordos realizados pelas unidades periféricas com a União destinem atribuições além ou aquém das condições de execução suportadas pelas mesmas ${ }^{133}$.

As diferenças territoriais constatadas no interior das Federações estruturadas na época que sucedeu à Segunda Guerra (em especial pontos de tensão que dificultavam a convivência pacífica de grupos populacionais abrigados em um mesmo território), aos poucos, passaram a ser compatibilizadas mediante o desenvolvimento de instrumentos jurídicos. A elaboração de arranjos constitucionais destinados a acomodar realidades distintas que potencialmente pudessem ensejar o aparecimento de conflitos federativos representou o despertar da consciência de que o caráter assimétrico dos Estados federais, invariavelmente existente em aspectos fáticos (população, dimensão territorial, índices socioeconômicos, história), deveria encontrar correlação nos dispositivos constitucionais destinados a disciplinar o pacto federativo formado. Assim é que se conclui ser o federalismo assimétrico uma fórmula jurídica que reflete e traduz as desigualdades regionais dos atores federativos; seu objetivo maior está em corrigir os desníveis que

\footnotetext{
${ }^{132}$ Cf. As Transformações do Estado Contemporâneo, Rio de Janeiro, Forense Universitária, 2009, pp. 2325.

${ }^{133}$ Maria PaUla Dallari BucCi ratifica essa advertência ao sublinhar que, "quanto mais se conhece o objeto da política pública, maior é a possibilidade de efetividade de um programa de ação governamental; a eficácia de políticas públicas consistentes depende diretamente do grau de articulação entre os poderes e agentes públicos envolvidos. Isso é verdadeiro especialmente no campo dos direitos sociais, como saúde, educação, previdência, em que as prestações do Estado resultam da operação de um sistema extremamente complexo de estruturas organizacionais, recursos financeiros, figuras jurídicas, cuja apreensão é a chave de uma política pública efetiva e bem-sucedida”, Direito Administrativo e Políticas Públicas, São Paulo, Saraiva, 2002, p. 249.
} 
inviabilizam a máxima eficiência da atuação dos órgãos governamentais em contextos de patentes heterogeneidades.

Frente a esse ambiente de profundas rupturas e de imediatas reconstruções, o federalismo evidenciou ser o esquema de estruturação de poder mais apropriado para expressivo número dos Estados formados. Além disso, a forma federativa transpareceu ser um eficiente meio para reorganizar Estados historicamente antigos, sobretudo aqueles que ainda não tinham encontrado um ponto de equilíbrio no tocante à racionalização do poder político $^{134}$. Na verdade, a Federação já vinha sendo empregada como sistema de organização de muitos Estados, entretanto, foram as contingências enfrentadas nesse período - notadamente as dificuldades de criação de estruturas sólidas que sustentassem as organizações estatais recém-criadas e a necessidade de adaptar o universo estatal às inúmeras exigências colocadas pelas determinantes da democracia social - que proporcionaram ao regime federativo projeção nunca antes vislumbrados, tornando-o referência para a ordenação do poder político no mundo contemporâneo ${ }^{135}$.

Nesse percurso, interessa grifar ainda que a transformação de territórios em Estados nacionais - o que, em muitas situações, ocorreu de forma súbita e pouco reflexiva - ecoou efeitos políticos de considerável envergadura. Apenas uma parcela ínfima desses Estados constituídos no pós-1945 dispunha de trajetória histórica caracterizada pela afirmação e respeito aos valores democráticos, o que demandou cuidados imoderados no sentido de evitar o surgimento de regimes desapegados aos interesses do povo. Foi preciso, então,

\footnotetext{
${ }^{134}$ Sobre a ascensão vertiginosa do federalismo nesse período DIMITRIOS KARMIS e WAYNE NORMAN anotam que "O espaço de tempo compreendido entre a Guerra Civil americana e a Segunda Guerra Mundial foi pouco produtivo para a história da teoria federalista. Escritores como Otto Von Gierke, Louis Le Fur, A. V. Dicey e James Bryce desenvolveram estudos institucionais e comparativos sobre o tema federalismo. O foco dos referidos trabalhos estava principalmente voltados aos aspectos formais do Estado federal. Ficaram de lado as análises fundadas na perspectiva ideológica, de forma que a maioria dos autores dessa época considerava o federalismo como sendo uma estrutura jurídica ligada a ideias conservadoras, percepção esta muito bem retratada por Harold Laski no ensaio intitulado de ‘A obsolescência do federalismo' (1939). Esse panorama mudou radicalmente depois da Segunda Guerra Mundial. Primeiro, o consenso de que o nacionalismo (e o estadismo nacional) foi o causador a guerra e o insucesso da Liga das Nações em evitar o confronto estimularam pensadores da resistência a enxergar o federalismo, no pós-1945, como o remédio definitivo para as mazelas crônicas da Europa. Em segundo lugar, a criação de dezenas de Estados multiétnicos, entre 1950 e 1960, o que aconteceu com o término do colonialismo europeu na África, Ásia e em outros lugares (a federação indiana é o mais espetacular e significativo exemplo dessas transformações), serviu de oportunidade para reformulação das finalidades do federalismo. Terceiro, ocorreu a emergência da discussão de temas como justiça intercomunitária e autonomia para determinados Estados multilinguísticos, como o Canadá, a Suíça, a Bélgica e a Espanha. Tudo isso conduziu para o desenvolvimento revigorado das apreciações jurídicas acerca do que deveria ser conservado ou melhorado no âmbito dos sistemas federativos, bem como sobre de quais maneiras os arranjos institucionais da Federação poderiam lidar melhor com problemas de identidades múltiplas e conflitantes", Theories of Federalism: A Reader, Dimitrios Karmis e Wayne Normann (eds.), Ob. cit., p. 191.

${ }^{135}$ A respeito das influências causadas pela doutrina da democracia social no campo do federalismo, verificar Cristiano Franco Martins, Princípio Federativo e Mudança Constitucional: Limites e Possibilidades na Constituição de 1998, Rio de Janeiro, Lumen Juris, 2003, p. 119.
} 
desenhar o Estado como agente garantidor e promovedor do progresso político, do desenvolvimento econômico e do respeito aos indivíduos, e, sem dúvida, os sistemas federativos tiveram de aproximar-se das diretrizes estabelecidas pela democracia.

A integração operada entre democracia e federalismo funcionou como importante ferramenta de oposição ao perigoso sistema de autoridade única, excludente da participação dos demais segmentos da tessitura social ${ }^{136}$. O Estado federal era a alternativa mais interessante para a obtenção de parâmetros aceitáveis de democratização e de pluralização do centro de decisões encarregado de guiar os rumos de todo o conjunto estatal, do meio social e dos indivíduos, e, certamente, é por esse motivo que HANSRUDOLF HORN preconiza ser o federalismo a base que permite a integração democrática e social mirada pelas organizações estatais da atualidade ${ }^{137}$. Coube, pois, à Federação acenar a possibilidade de concretizar, no Estado, o ideal de fazer com que as decisões do poder político correspondessem ao produto final do consenso das partes ${ }^{138}$.

\section{II.1.2. A Consagração da Democracia Social e a Ascensão da Tese do Federalismo Assimétrico}

A democracia social clarificou aos gênios encarregados de idealizar o regime federativo que era insuficiente cuidar apenas da dissipação dos centros decisórios do poder. Fez com que fosse evidenciado que a mera pulverização do poder político não representava nenhuma garantia de êxito nas Federações, uma vez que se percebeu estar, na essência do pacto federativo, a ordem de transformá-lo numa eficiente fórmula de alcance do equilíbrio entre as unidades autônomas. A Constituição deve, portanto, veicular comandos normativos que permitam a todos os entes federados obter iguais vantagens e benefícios provenientes do funcionamento das instituições políticas, independentemente das variadas diferenças factuais que existam entre eles.

\footnotetext{
${ }^{136}$ Registra DALMO DE ABREU DALLARI que "a organização federativa é incompatível com a ditadura. Isso tem ficado muito evidente através da História, não havendo exemplo de convivência de ambas. Onde havia federalismo e se instalou uma ditadura ocorreu a concentração do poder político. E mesmo que mantida formalmente a federação, a realidade passou a ser um Estado Unitário, com governo centralizado. São exemplos disso a Alemanha com a ascensão de Hitler, o Brasil com a ditadura Vargas e a Argentina de Perón. Federalismo e ditadura são incompatíveis" (O Estado Federal, São Paulo, Ática, 1986, p. 66). Em igual direção, Mônica Herman Salem Caggiano, Direito Constitucional Estadual, $1^{\circ}$ Painel, in Temas de Direito Constitucional Estadual e Questões sobre o Pacto Federativo, Assembleia Legislativa do Estado de São Paulo, ALESP, São Paulo, 2004, p. 114.

${ }^{137}$ Cf. Aspectos Sociales Intrínsecos del Derecho Contemporâneo, in Cuestiones Constitucionales: Revista Mexicana de Derecho Constitucional, $\mathrm{n}^{\circ}$ 5, 2001, p. 164.

${ }^{138}$ Cf. Augusto Zimmermann, Ob. cit., p. 41.
} 
Assim, KLAus SchubERT observa que, nos dias atuais, as preocupações teóricas de fundamentação jurídica do regime federativo, assunto que ocupou os mais respeitados teóricos do Estado antes do final da primeira metade do século XX, ficaram relegadas a uma posição de importância secundária. O interesse concentra-se agora nos aspectos funcionais da organização federal, bem como na estruturação dos serviços públicos, sendo que a diretriz política determinante aponta como principal objetivo da compreensão do funcionamento das instituições político-jurídicas - dentre as quais se insere o federalismo o incremento da eficácia prestacional do Estado moderno ${ }^{139}$. Foi, por certo, essa profunda mudança de foco que permitiu ao federalismo transformar-se em valioso instrumento para enfrentar questões mais tangíveis e ciosas de respostas concretas, exigindo do pacto federativo soluções de apaziguamento em relação aos pontos de tensão verificados no funcionamento dos órgãos do Estado, a exemplo do que ocorre com a problemática da diversidade regional.

Na prática, essa tendência, num primeiro momento, traduziu-se na instauração de um comportamento político de tolerância acerca da questão da diversidade naturalmente existente entre as distintas regiões do Estado, aspecto pouco conveniente aos governos autoritários, porém muito significativo ao desenvolvimento das sociedades livres ${ }^{140}$. A evolução desse pensamento desembocou na afirmação da postura de que o desenvolvimento pleno do conjunto federativo, para acontecer, demandaria antes a superação das drásticas e nefastas desigualdades causadoras do afrouxamento dos laços que mantêm as partes unidas em prol de um valor maior: o interesse nacional. A preocupação em compatibilizar a diversidade, acomodando-se os desníveis territoriais que se mostrassem prejudiciais à unidade do conjunto, ganha destaque e passa a figurar permanentemente nos discursos políticos e acadêmicos relacionados com o Estado composto nos anos que sucederam à Segunda Grande Guerra

As exigências colocadas ao Direito Constitucional, a partir da assunção dessa nova concepção de regime federativo, levaram à positivação, em muitas Constituições contemporâneas, de institutos jurídicos característicos do fenômeno da assimetria. De fato, a indeclinabilidade de compatibilização das disparidades regionais - constatadas por meio do mapeamento dos diversos cenários territoriais sobre os quais as unidades federadas

\footnotetext{
${ }^{139}$ Cf. Ob. cit., p. 170.

${ }^{140}$ Cf. Augusto Zimmermann, Ob. cit., p. 41. Em idêntico sentido, assinala Esther SeIJAS Villadangos que as formas assimétricas de organização territorial do poder político do Estado "convertem-se em modelo institucionais que contribuem para o reconhecimento das identidades culturais diferenciadas que existem dentro de um Estado e, sobretudo, para a materialização da tolerância”, Ob. cit., p. 256.
} 
encontravam-se instaladas - fez com que o federalismo passasse a vir acompanhado de arranjos consagradores da diversidade. Muito mais do que descentralizar territorialmente o poder político, foi adquirida a consciência de que o Estado federal deveria estar pronto para atender satisfatoriamente os reclamos apresentados por todas as unidades periféricas, admitindo-se, nesse particular, a previsão de diferenciações perfeitamente justificáveis, proporcionais e razoáveis entre os entes federados - os quais, até então, eram entendidos pelo pensamento constitucional como sujeitos dotados de absoluta igualdade formal.

Os influxos causados pela dispersão dos valores democráticos em todos os campos de conformação estrutural do Estado, sobretudo a partir da compreensão de que o governo deveria promover a igualdade substancial entre os indivíduos, despertaram a consciência acerca da urgência de promover o ajustamento das disparidades regionais de um mesmo conjunto estatal $^{141}$. Numa escala macroestrutural, ao se estabelecer a obrigatoriedade de dispensar tratamento igualitário aos indivíduos, a autoridade estatal percebeu que teria de cuidar também da redução das desigualdades regionais que prejudicavam a coesão do sistema federativo. Do contrário, seria impossível efetivar o respeito integral à autodeterminação dos grupos sociais, de modo a conservar suas tradições, história e características socioeconômicas. Sem tal entendimento firmemente institucionalizado, não haveria a menor possibilidade de fazer com que o Estado atuasse na condição de agente promotor da justiça social, tal qual preconiza os quadrantes do Estado Social.

A ideia de contornar os impasses originados dessas disparidades surgidas no interior das Federações representa o marco de partida para a compreensão e o ininterrupto desenvolvimento da tese da assimetria. Pelo que se depreende com relativa facilidade, o federalismo assimétrico encabeça propósitos muito caros para a permanência das organizações estatais compostas e para a concretização de objetivos políticos que se ancoram no plexo de valores afeitos ao princípio democrático. Nesse compasso, convém lembrar que o Direito precisa estar continuamente a serviço das metas políticas e dos

\footnotetext{
${ }^{141}$ Sobre essa questão, Gilberto BERCOVICI assevera que "o objetivo primordial do Estado Social, assim, torna-se a busca da igualdade, com a garantia da liberdade. O Estado não se limita mais a promover a igualdade formal, a igualdade jurídica. A igualdade procurada é a igualdade material, não mais perante a lei, mas através da lei. A igualdade não limita a liberdade. O que o Estado busca garantir é a igualdade de oportunidades, o que implica na liberdade, justificando a intervenção estatal" (Desigualdades Regionais, Estado e Constituição, São Paulo, Max Limonad, 2003, pp. 52-53). Sufraga essa ideia SERGIO CAdemartori, Estado de Direito e Legitimidade - uma Abordagem Garantista, 2a ed., Campinas, Millennium, 2006, p. 210.
} 
programas sociais do Estado, cabendo ao constitucionalismo e à democracia informar de modo preciso como alcançar os escopos afeitos à noção de Estado de Bem-Estar Social ${ }^{142}$.

Por se ter delegado à Federação, desde os seus primórdios, o papel de racionalizar o uso do poder estatal, protegendo-se sempre a liberdade dos indivíduos e de grupos sociais, o núcleo essencial do regime federativo não poderia ficar incólume às radicais mudanças assistidas no período de intensas transformações representado pelo pós-1945 ${ }^{143}$. Com a salutar junção do federalismo e da democracia, intrinsecamente amoldados pelos comandos principiológicos da solidariedade, redefiniram-se muitas das noções clássicas que orientavam o Estado federal. Dentre tais reformulações, a estrita paridade entre os entes federados sofreu mitigação, sobretudo naqueles Estados em que a heterogeneidade colocava-se como fator de complicação para a governabilidade, o que fez a assimetria federativa consagrar-se na órbita dos documentos constitucionais mais recentes.

A incorporação de vetores axiológicos afinados à democracia e à solidariedade no contexto do Estado federal levou à sedimentação da diretriz de que existe um importante limite a ser observado em matéria de desenvolvimento do processo autonômico: a autonomia federativa não pode ser medida exclusivamente pela capacidade de autoorganização, autogoverno, autoadministração e autolegislação. Requer também o cômputo de outras variantes para a obtenção de resultados adequados nessa delicada equação, a exemplo da articulação política apresentada pelas unidades da Federação em face dos demais atores do concerto federativo. Por isso é que se exige muita atenção no desenho das estruturas que sustentarão o regime federativo para que sejam evitadas (e corrigidas, caso necessário) drásticas desigualdades de tipo econômico, geográfico e social entre as unidades do Estado $^{144}$.

\footnotetext{
${ }^{142}$ Cf. Nina RANIERI, Sobre o Federalismo e o Estado Federal, in Cadernos de Direito Constitucional e Ciência Política, ano 3, nº 9, out./dez. de 1994, p. 92.

${ }^{143}$ No tocante à adoção do Welfare State, Lenio Luiz Streck e José Luiz Bolzan DE Morais esquadrinham que essa feição do Estado "emerge definitivamente como consequência geral das políticas definidas a partir das grandes guerras, das crises da década de 1930, embora sua formulação constitucional tenha se dado originalmente na segunda década do século XX (México, 1917; e Weimar, 1919). O new deal americano de Roosevelt, o keynesianismo e a política social do pós-Segunda Guerra na Inglaterra estão entre os fatores relevantes que demonstram a estrutura que está se montando. Com a I Guerra Mundial, tem-se a inserção definitiva do Estado na produção (indústria bélica) e distribuição (alimentos etc.); com a crise de 1929, há um aumento das despesas públicas para a sustentação do emprego e das condições de vida dos trabalhadores; nos anos de 1940, há a confirmação desta atitude interventiva, instaurando-se a base de que todos os cidadãos como tais têm direito a ser protegidos contra dependências de curta ou longa duração" ( $O b$. cit., pp. 78-79). Consultar também ALEXANDRE Mussor MoReIRA, A Transformação do Estado: Neoliberalismo, Globalização e Conceitos Jurídicos, Porto Alegre, Livraria do Advogado, 2002, p. 72.

${ }^{144}$ Cf. José Alfredo de Oliveira Baracho, O Princípio da Subsidiariedade: Conceito e Evolução, in Revista de Direito Administrativo, vol. 200, abr./jun. 1995, p. 34.
} 
Analisada pelo prisma constitucional, a Federação encontra, em tais medidas de equalização, a força-motriz que insufla vida ao federalismo assimétrico, tornando-o um tema inesgotável para os debates constitucionais. Desse modo é que DIRCÊO TORRECILLAS RAMOS considera a pertinente distribuição de encargos e de receitas um fator de elevada repercussão para a assimetria, uma vez que "não se pode na busca do equilíbrio provocar outro tipo de desigualdade ou ajudar outras Regiões de forma a prejudicar a sua própria ou ao seu Estado"145. Daí porque os mecanismos de assimetria, ao serem aplicados, jamais poderão trazer embaraços à governabilidade das partes, em especial no que tange ao atendimento das particulares necessidades apresentadas pela população de cada ente, haja vista que a compatibilização da diversidade regional, coordenada em geral pelo poder central, está absolutamente impedida de se valer do argumento de que as ações centralizadoras da União devem ser seguidas em prestígio à unidade do conjunto.

\section{II.2. A Reformulação do Pacto Federativo em Atenção aos Condicionantes do Pluralismo Político}

As progressivas escolhas realizadas pelos Estados contemporâneos, no período subsequente ao término da Segunda Guerra Mundial, em eleger e empregar o federalismo como principal regime de organização espacial do poder denotam, numa primeira síntese, compromisso político com a preservação dos valores consectários do conceito de pluralismo: integração, autodeterminação, tolerância e participação. Entretanto, ao contextualizar essa tendência tomando como referência o desenvolvimento da dogmática constitucional em seu sentido amplo, visualiza-se ainda que, em parte, o Estado federal serviu de alicerce para, anos mais tarde, edificar-se o hoje conhecido "constitucionalismo moralmente reflexivo", tal qual a proposição difundida por J. J. GOMES CANOTILHO.

Conforme essa linha de interpretação, explica o mestre português que o Direito Constitucional vem abandonando a inflexível noção de dirigismo estatal, o que, por conseguinte, abre espaço para a positivação de sistemas políticos instruídos a permitir a coexistência de valores em diversas perspectivas, mesmo se houver contrariedade entre eles. Assim, nos Estados em que se adotam mecanismos assimétricos, adquire realce a preocupação de superar as desigualdades regionais; a instauração da consciência de tolerância e de diálogo entre as culturas; a consciência de obter um desenvolvimento

${ }^{145}$ O Federalismo Assimétrico, Ob. cit., pp. 212-213. 
sustentável da economia; e, principalmente, a ordem de se estabelecer um sólido contrato democrático, no qual a democracia funciona como peça insubstituível de governo, revestindo-se da condição de garantia de permanência das instituições políticas consolidadas $^{146}$.

Nessa quadra, CRISTIANO FRANCO MARTINS registra a interessante relação de interdependência que há entre o regime federativo e o pensamento pluralista. Enuncia que o Estado federal corresponde à expressão ideológica do pluralismo, haja vista tratar-se de um fenômeno sociopolítico que estabelece (ou tem a pretensão de estabelecer) um sistema de integração política eficiente em comunidades plurais. Além disso, grifa existir ainda sensível proximidade entre a forma federativa e a axiologia que informa o princípio da eficiência, na medida em que este mandamento de direito consubstancia-se num "valor social que podemos compreender pelo sentimento de que uma sociedade, para atingir uma determinada finalidade, deve sempre buscar o meio que, dentre as opções possíveis, se apresente mais adequado e que produza o máximo de resultados com o mínimo de prejuízos" ${ }^{\text {"147. }}$.

A eficiência federativa, em verdade, corresponde a uma salutar orientação operacional a ser agregada ao plexo de vetores característicos do pluralismo. É que a estruturação dos Estados compostos deverá inexoravelmente ser idealizada com vistas a proporcionar a efetivação das propostas de tornar o regime federativo em importante penhor da autodeterminação, da tolerância, da participação e da integração políticas ${ }^{148}$. Por conta disso, o federalismo assimétrico, em geral, encontra maior receptividade em sociedades verdadeiramente plurais, as quais acabam se mostrando abertas e permeáveis a mudanças, em especial propostas tendentes a tornar mais eficientes os comandos primários de descentralização político-territorial do poder, tal qual a assimetria.

Visualiza-se que a sedimentação de grande parte dos ideais democráticos em um determinado Estado faz-se acompanhar da acentuação dos atrativos que levam à adoção do regime federativo, uma vez que, sob os mais diferentes pontos de vista, a descentralização política parece figurar como elemento viabilizador das aspirações democráticas ${ }^{149}$. Fragmentar o poder é a saída que melhor atende aos reclamos decorrentes da necessidade de preservar a diversidade histórica e a individualidade das partes do conjunto estatal,

\footnotetext{
${ }^{146}$ Cf. Rever ou Romper com a Constituição Dirigente? Defesa de um Constitucionalismo Moralmente Reflexivo, in Cadernos de Direito Constitucional e Ciência Política, ano 4, n 15, abril/junho de 1996, pp. 16-17.

${ }^{147}$ Ob. cit., pp. 33-34.

${ }^{148}$ Cf. CRistiano Franco Martins, Ob. cit., p. 33.

${ }^{149}$ Cf. Celso Bastos, A Federação no Brasil, Ob. cit., p. 2.
} 
notadamente nas Federações que congregam entes muito díspares. A maior capacidade para proteger minorias, respeitando-se sempre a liberdade e os demais consectários do regime democrático, por certo, depende em demasia do sucesso obtido pelos aparatos governamentais elaborados para concretizar o pacto federativo ${ }^{150}$.

Nesse diapasão, NINA RANIERI desenvolve interessante intelecção, registrando que "é de se considerar, pois, que a divisão em bases territoriais se mostra mais eficaz que a divisão em bases funcionais, no que respeita a aspectos de contenção do poder, da realização da democracia, da participação popular, da preservação de culturas locais. Neste particular, a descentralização legislativa permite $o$ respeito às peculiaridades socioeconômicas e culturais de cada estado, além de conter qualquer expansionismo latente dos poderes federais, dada a enumeração exaustiva das competências" ${ }^{\prime 151}$. Convalida essa impressão José ALFREDO DE OLIVEIRA BARACHO, ao admitir que "o federalismo convive melhor com os sistemas democráticos, pelo que é incompatível com as formas autocráticas" ${ }^{152}$, pois o autoritarismo implica em centralização e em rechaço à ampla autonomia dos entes federados.

De tal sorte, se é verdadeira a sentença de que o regime democrático e o florescimento do federalismo estão intimamente imbricados, maior razão ainda há em afirmar que essa conjugação foi essencial para o desenvolvimento das ideias que sustentam o Estado federal apresentado em sua feição assimétrica. Com efeito, as construções jurídicas que buscam acomodar a diversidade territorial exigem antes a realização de intensos debates e estudos para a delimitação precisa dos desníveis territoriais, culturais, naturais, políticos ou econômicos que deverão ser ajustados mediante o emprego de engenhos jurídicos. E, evidentemente, tal etapa preparatória jamais ocorreria em Estados autoritários, sempre avessos a intensas e profundas discussões sobre questões de governo, sobretudo quando o foco é incrementar a autonomia político-administrativa de parcelas do conjunto estatal.

A relação de causa e efeito instaurada entre o emprego da democracia e a corporificação do pensamento teórico do federalismo assimétrico é avultada diante das considerações de AMARTYA SEM, que esquadrinha que "os direitos políticos e civis, especialmente os relacionados à garantia da discussão, debate, crítica e dissensão abertos, são centrais para os processos de geração de escolhas bem fundamentadas e refletidas.

${ }^{150}$ Cf. José Alfredo de Oliveira Baracho, O Princípio da Subsidiariedade: Conceito e Evolução, Ob. cit., p. 48 e Fernanda Dias Menezes de Almeida, Competências na Constituição de 1988, Ob. cit., p. 11.

${ }^{151}$ Ob. cit., p. 91.

${ }^{152}$ Teoria Geral do Federalismo, Ob. cit., p. 66. 
Esses processos são cruciais para a formação de valores e prioridades, e não podemos, em geral, tomar as preferências como dadas independentemente de discussão pública, ou seja, sem levar em conta se são ou não permitidos debates e diálogos"153. Como não poderia deixar de ser, onde houver governos que se pautem pelas reais necessidades apresentadas pelo povo e pelas unidades políticas criadas para viabilizar a governabilidade, nunca faltarão diálogos consistentes e, por conseguinte, ter-se-á a presunção de que as decisões do Estado traduzem as expectativas apuradas a partir da confluência de vontades de todos os atores que compõem o universo estatal.

Impossível fazer uso dos arranjos institucionais e dos demais mecanismos ligados à assimetria sem, contudo, conclamar anteriormente amplos e persuasivos debates que, por seu turno, devem envolver não apenas os indivíduos e grupos diretamente interessados no processo de acomodação da diversidade, mas toda a Federação. A inegável repercussão da matéria envolvida no discurso assimétrico recomenda fortemente que esses estudos sejam exaustivos com vistas a evitar a tomada de decisões políticas que, em vez trazer melhorias aos impasses existentes, problematiza ainda mais tais pontos de tensão. Eventuais fracassos das ferramentas de acomodação da diversidade constituem-se em preocupantes fatores de desagregação de Estados federais marcados por profundos desníveis territoriais.

Além disso, um dos principais aspectos afeitos ao exponencial emprego do federalismo, nas democracias consolidadas na última metade do século XX, foi, por certo, o cuidado que passou a ser dispensado no trato de dissensos culturais - questões de difícil solução, originadas, no geral, em torno de diferenças de língua, religião, raça, identidades étnica e ideológica. Transparece, aqui, o destacado uso político que se delega ao regime federativo na proteção das minorias, bem como aos interesses territoriais de comunidades diminutas. Preservar a identidade de grupos minoritários, salvaguardando-os de sucumbir frente às pressões e imposições colocadas pela maioria, é tarefa que exige habilidade, inteligência e, sobretudo, apurada capacidade de negociação ${ }^{154}$.

Verifica-se que a tendência de o federalismo preservar a diversidade acaba credenciando-o para a missão de guardar a identidade de grupos que ostentam valores,

\footnotetext{
${ }^{153}$ Desenvolvimento como Liberdade, São Paulo, Companhia das Letras, 2000, p. 181.

${ }^{154}$ Registre-se, por oportuno, que perfilha entendimento dissonante quanto à viabilidade do regime federativo em contextos marcados por desigualdades ALEXIS DE TOCQUEVILLE, consonante se depreende do excerto que segue: "Há um fato que facilita admiravelmente, nos Estados Unidos, a existência do governo federal. Os diferentes Estados têm não só mais ou menos os mesmos interesses, a mesma origem e a mesma língua, mas também o mesmo grau de civilização, o que torna quase sempre o acordo entre eles coisa fácil. Não sei se há alguma nação europeia pequena o bastante para não apresentar em suas diferentes partes um aspecto menos homogêneo que o povo americano, cujo território é tão grande quanto a metade da Europa", Ob. cit., pp. 189190.
} 
objetivos e vontades peculiares. As minorias encontram, nos acordos intergovernamentais celebrados no interior da Federação, a possibilidade de preservar, dentro de uma proporcionalidade aceitável, sua representatividade política na formação da vontade nacional $^{155}$. Essa tarefa, desempenhada com triunfo, sobretudo por regimes federativos assimetricamente organizados, acaba por aproximar a descentralização política com o Estado Democrático Social, principalmente ao admitir que esse, conforme afirma PAULO BONAVIDES, é "o Estado de todas as classes, Estado fator de conciliação, o Estado mitigador de conflitos sociais e pacificador necessário entre o trabalho e o capital" ${ }^{156}$. Coube, em suma, aos valores apregoados pela democracia social sedimentar o comando de que a contradição entre igualdade política e desigualdade social fosse superada mediante a realização de transformações de caráter superestrutural na forma de Estado ${ }^{157}$.

Realizada dentro de parâmetros constitucionalmente demarcados, a descentralização política do poder, de forma a possibilitar a inclusão dos diversos segmentos que se formam em sociedades políticas complexas, fez com que se formasse interessante ponto de intersecção entre o Estado federal e a democracia; e foi isso que levou à configuração do hoje conhecido como federalismo assimétrico. Assim, as estruturas federais foram transformadas em peças de organização do Estado e também de compatibilização das diferenças regionais. A previsão de níveis mínimos e igualitários de autonomia entre as unidades periféricas de Estados altamente heterogêneos, não raro, passou a demandar o emprego de técnicas e de recursos antes impensáveis nas Federações tradicionais.

\section{II.2.1. As Principais Técnicas de Assimetria Empregadas nos Estados Sociais}

Geralmente, contextos regionais em que entes federados estão dispostos como resultado de lentos e significativos processos de diferenciação histórica, econômica, cultural ou política são os ambientes mais propícios à utilização do federalismo assimétrico. A sensibilidade quanto a fatores particularizantes, enaltecidos pela faceta socializante do Estado, evita a criação de regimes homogeneizantes e avessos à

\footnotetext{
155 Essa estratégia consegue aplacar antagonismos antes declarados - inclusive situações de hostilidade seculares. Cf. Alain-G. GAgnon, Quebec y el Federalismo Canadiense, Madrid, Consejo Superior de Investigaciones Científicas, Instituto de Estudios Sociales Avanzados, 1998, p. 29.

${ }^{156}$ Do Estado Liberal ao Estado Social, $8^{\text {a }}$ ed., São Paulo, Malheiros, 2007, p. 185.

${ }^{157}$ Paulo Bonavides, Do Estado Liberal ao Estado Social, Ob. cit., p. 185.
} 
preservação da diversidade ${ }^{158}$. Percebe-se, ademais, que embora o Estado federal demonstre irrefutável ligação com a democracia, foi o compromisso com a efetivação dos direitos sociais e em fazer com que o princípio da igualdade tomasse forma em seu contorno substantivo que deflagrou o movimento em prol da assimetria.

Não foi por acaso que CHARLES D. TARLTON desenvolveu seus estudos, os quais se tornaram marcos para a compreensão da assimetria na Federação, nos anos subsequentes a 1965. Para que se compreenda o contexto vivido naquela época, vale lembrar que, nos Estados Unidos, foram tomadas algumas medidas para a concessão de direitos de cidadania a toda a população, buscando-se colocar fim a discriminações políticas de índole racial, podendo-se citar o Civil Rights Act e o Voting Civil Act, editados, respectivamente, em 1957 e 1965. Foi justamente nesse período que aquele país enfrentou novamente situações de forte contraste entre Estados do Sul e do Norte; entretanto, o ponto fulcral agora não era a manutenção do trabalho escravo, mas sim a observância das disposições encartadas nos referidos textos legais ${ }^{159}$. Diante desse contexto, TARLTON chegou à conclusão de que "o grau de harmonia ou de conflito dentro de um Estado federal pode ser considerado como uma função do desenho simétrico ou assimétrico que prevalece no sistema"160.

Ao afirmar que o Estado Social de Direito caracteriza-se notadamente "pelo fato de estar montado sobre uma sociedade pluralista em que os diferentes grupos sociais realizam funções relevantes" ${ }^{\prime 161}$, PABLO LUCAS VERDÚ indica um relevante dado que favoreceu a consagração do Estado federal assimétrico nos países que se preocupavam com os direitos de grupos oprimidos. O fato é que, antes de o pluralismo ocasionar a formação de uma sólida consciência de solidariedade entre todos os grupos que interagem no meio social, é imprescindível que se tenha um sistema de organização estatal em que as unidades político-administrativas tenham a mesma importância, não obstante as diferenças que trouxerem estampadas em seu interior. A construção de um Estado composto nesses moldes figura como condição indispensável para a que unidade seja o mais proeminente objetivo cultuado pelas partes integrante do Estado, ainda que, para alcançá-la, tenha-se de fazer ajustes diferenciados de tolerância e de ajuda mútua entre os atores envolvidos ${ }^{162}$.

\footnotetext{
${ }^{158}$ Em combate à aquisição de um caráter fortemente homogeneizador e centralizado por parte do Estado federal, PABLO A. RAMELLA adverte que "o federalismo desaparece em razão, simultaneamente, da falta de equilíbrio entre as diversas regiões e da subordinação dos problemas nacionais ao interesse do poder central. De fato, nessas circunstâncias o federalismo existirá apenas nos textos, porque, na realidade, ter-se-á um estado unitário disfarçado", Ob. cit., pp. 44-45.

${ }^{159}$ Cf. Esther Seijas VilladangOs, Ob. cit., pp. 193-200.

${ }^{160}$ Ob. cit., p. 871.

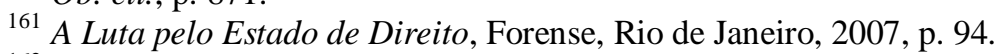

${ }^{162}$ Idem, Ob. cit., p. 95.
} 
Nas Federações heterogêneas, a diversidade não pode ser apenas tolerada, deve, ao contrário, receber efetivo tratamento constitucional a fim de não atravancar o sucesso na celebração de pactos federativos consistentes e funcionais. Os arranjos assimétricos provam que, às vezes, a padronização de tratamento dispensado às partes federais dificulta a obtenção da integridade, pois deve-se buscar, no respeito da diferença, a fórmula para obter estabilidade. A tradução, nas Constituições, das desigualdades factuais que se revelam complicadas à unidade requer a realização de amplo balanceamento das características apresentadas pelas regiões congregadas, analisando-se, em síntese, quais impactos as diferenças de, por exemplo, riqueza, história, cultura e extensão territorial podem causar à unidade do conjunto, caso seja adotada a orientação de considerar as partes como sendo formalmente idênticas ${ }^{163}$.

Conforme destaca Cezar Saldanha Souza Junior, o federalismo "vem caminhando progressivamente no sentido de reconhecer, a par da liberdade e da igualdade, a premência de outros valores, como a justiça e a solidariedade, de modo a compor um quadro ético mais completo do bem comum" ${ }^{\text {164 }}$. E é exatamente essa orientação que fortalece o perfil assimétrico construído pelas Federações contemporâneas, as quais, ao adotar as diretivas do Estado Social, renovaram os vetores que disciplinam o processo de descentralização política antes praticada, uma vez que fatores socializantes transformaram o Estado em responsável primeiro pelo respeito e pela prestação dos direitos fundamentais aos mais diferentes segmentos da sociedade. A ordem estabelecida, de atender todos os agrupamentos humanos inseridos no Estado, obrigou os órgãos governamentais a atuar ativamente para oferecer, sob os mais adversos cenários, mínimas condições existenciais aos indivíduos.

A compatibilização da diversidade territorial fez-se precisa porque, do contrário, não haveria como atender a todos com idênticos índices de eficiência, tendo em vista as muitas complicações que a desigualdade ocasiona ao sucesso das políticas públicas elaboradas pelo poder central, cuja implementação exige o invariável engajamento dos entes periféricos ${ }^{165}$. Assim é que se visualiza, após a década de 60 do século XX, interessante reconfiguração da relação estabelecida entre Estado e sociedade, de modo que este passou a buscar instituir e preservar o equilíbrio, o compromisso e a coexistência pacífica com o meio social, inclusive naqueles ambientes dotados de acentuadas

${ }^{163}$ Cf. DiRCÊO ToRrecillas Ramos, O Federalismo Assimétrico, Ob. cit., pp. 59-60.

164 Estudo Introdutório: Em Torno do Sentido do Federalismo, in Direito do Estado - Estudos sobre Federalismo, Cezar Saldanha Souza Junior e Marta Marques Avila (coord.), Ob. cit., p. 28.

${ }^{165}$ Cf. Gilberto Bercovici, Desigualdades Regionais, Estado e Constituição, Ob. cit., p. 50. 
disparidades internas ${ }^{166}$. Novas e complexas estruturas estatais tiveram de ser desenvolvidas, sendo que o propósito que impulsionava a idealização das mesmas era o de neutralizar os efeitos da diversidade federativa em matéria de acesso aos serviços públicos essenciais.

As unidades autônomas, antes tidas como absolutamente iguais entre si, começaram a receber benefícios e oportunidades específicos, haja vista que os programas governamentais que envolviam cooperação federativa tiveram de aplicar a técnica da diferenciação por ser a mais razoável para contornar os problemas causados pela inconstância dos caracteres regionais. Também foi aventado, em determinados Estados, o recurso de prever competências constitucionais de forma desigual aos entes, em especial no caso de heterogeneidades que teriam de ser tratadas somente mediante a atuação exclusiva do governo regional, sem o emprego de práticas cooperativas. A questão da acomodação da diversidade, antes circunscrita aos domínios da Ciência Política, ganhou projeção nos debates constitucionais que versavam sobre a adequação do Estado aos determinantes da democracia social: a arquitetura de muitas Federações, desde então, passou a contar com mecanismos habilitados a proporcionar a equalização das diferenças constatadas.

Consolidou-se o entendimento de que os pontos de diferenciação, em vez de ser ignorados ou exterminados, desde que devidamente tratados pela dogmática jurídica, deveriam ser preservados para não esvaziar a essência do federalismo. Os instrumentos jurídicos teriam de combater os reflexos decorrentes da desigualdade, já que atitudes de inércia em relação a tais pontos certamente impossibilitariam o alcance do esperado espírito de equilíbrio, que, por seu turno, constitui exigência indispensável à construção da unidade nacional e do bem-estar das populações localizadas no seio do Estado. Desse modo, a partir da combinação do regime federativo com os influxos democráticos, a diversidade plasmada no âmbito territorial passou a ser garantida, e isso fez com que as unidades da Federação deixassem de ser entendidas como meras peças de governo e fossem consideradas como sendo "o espaço no qual se produzem as relações sociais e econômicas geradoras de níveis específicos de equilíbrio, desigualdades ou

${ }^{166}$ Cf. GloRia Regonini, Dicionário de Política, Norberto Bobbio, Nicola Matteuci e Gianfranco Pasquino (coord.), $7^{a}$ ed., Brasília, Editora Universidade de Brasília, 1995, p. 419. 
marginalização, dependendo do grau de conexão que possui com os demais atores do conjunto" ${ }^{, 167}$.

Complementa ainda esse panorama a observação de que, muito embora o núcleo do Estado federal repouse em conceitos políticos relacionados com formas institucionais de distribuição espacial do poder, a verdade é que, em razão da imposição de padrões democráticos modernos, na atualidade o regime federativo somente demonstra ser viável quando ancorado em estruturas econômicas cujo dinamismo aponte para a integração cada vez maior dos espaços federados ${ }^{168}$. A desconsideração desse aspecto desemboca, em maior ou menor medida, na submissão de alguns entes autônomos - geralmente os mais debilitados e carecedores de medidas compensatórias - em face de outros dotados de maior força e expressividade na organização estatal composta, fato esse que ressoa negativamente na consolidação de um pacto federativo ajustado. Impõe-se, por conseguinte, a recomendação de que as unidades da Federação precisam ser entendidas como materialmente iguais pelo poder central, mesmo que para tanto assimetrias jurídicas tenham de ser empregadas, pois as negociações entre os entes periféricos correspondem hoje ao mais indicado modo de impedir o aumento da desigualdade econômica interregional.

\section{II.2.2. A Assimetria Federativa e o Contorno às Adversidades que Desestimulam a Democracia}

Pontuada a íntima relação de convergência entre a democracia social e o reforçado emprego da forma federativa de Estado, principalmente em países que se voltam à promoção dos direitos que compõem o catálogo dos direitos fundamentais, cabe analisar quais são as contribuições que a assimetria traz para essa conjugação de valores. Sobre tal elo, afirmam AlAin-G. GAGNON e CHARLES GiBBS que o "federalismo assimétrico apenas pode ajudar a gerenciar os problemas políticos, e não resolvê-los" ${ }^{169}$, uma vez que essa faceta da Federação abre caminho para a pacificação e para o aperfeiçoamento do sistema político, sem, contudo, renovar integralmente os laços associativos. Democracia e Estado federal apresentam-se, pois, como peças imprescindíveis - que precisam estar sintonizadas

167 JuAn ROMERo GONZÁlez, El Gobierno del Territorio en España. Balance de Iniciativas de Coordenacíon y Cooperacíon Territorial, in Boletín de la A.G.E., n 39, 2005, p. 61.

${ }^{168}$ Cf. José LuIs FIORI, O Federalismo diante do Desafio da Globalização, in A Federação em Perspectiva: Ensaios Selecionados, Rui de Britto Álvares Affonso e Pedro Luiz Barros Silva (org.), Ob. cit., p. 25.

169 The Normative Basis of Asymmetrical Federalism, in Accommodating Diversity: Asymmetry in Federal States, Robert Agranoff (ed.), Ob. cit., p. 93. 
entre si - para que as estruturas estatais sejam autênticos canais de difusão da tolerância, da eficiência e de todos os aspectos do pluralismo.

Nesse ponto, o conhecido axioma de ROBERT A. DAHL merece ser apreciado com vistas a compreender o terreno das Federações assimétricas. Antes de analisar a proposição de DAHL, não é exagerado assinalar que a obra desse autor evidencia esmerado empenho na intelecção dos pontos subjacentes ao fenômeno democrático nas sociedades contemporâneas, sendo que as conclusões obtidas, em regra, acabam sendo pertinentes ao Direito Constitucional. A influência que a arquitetura federativa pode causar no funcionamento das instituições democráticas denota forte indício de que é inviável apartar ambos os temas, de modo que as intersecções que existem entre descentralização política e governo democrático precisam ser mapeadas antes do emprego de quaisquer normas jurídicas que visem a disciplinar a Federação.

Com efeito, proclama DAHL que "instituições políticas democráticas têm maior probabilidade de se desenvolver e resistirem num país culturalmente bastante homogêneo e menor probabilidade num país com subculturas muito diferenciadas e conflitantes" ${ }^{170}$. Esse raciocínio embora pareça, num primeiro momento, desestimulante à utilização do sistema federativo em contextos que exigem a acomodação da diversidade, na verdade, não passa de uma salutar advertência que, caso venha a ser fielmente seguida, possibilitará a obtenção do sucesso da democracia em lugares onde, aparentemente, os postulados democráticos jamais vingariam. Numa investigação mais pormenorizada, o que se observa não é exatamente a configuração de uma relação de contrariedade entre a regra estabelecida pelo cientista político e as situações empiricamente testadas pela experiência federalista.

Ocorre que, não obstante as condições normais de alocação do poder territorial não encorajem a instalação de verdadeiros regimes democráticos em cenários de grandes heterogeneidades, as possibilidades oferecidas pela assimetria federativa em matéria de compatibilização de disparidades precisam ser ponderadas. Assim, o emprego dos mecanismos assimétricos nas Federações atualmente existentes acaba sendo um complemento à máxima proposta por ROBERT A. DAHL, importando, na prática, em aconselhamento para a fusão da democracia com os institutos do federalismo. Constata-se, desse modo, que, nos países onde há diversos grupos conflitantes em decorrência de

\footnotetext{
${ }^{170}$ Sobre a Democracia, Brasília, Editora Universidade de Brasília, 2001, p. 166.
} 
questões históricas e de formação social, o federalismo assimétrico apresenta-se como solução para evitar a indesejada fragmentação completa e definitiva do território.

Apesar de não existir na obra de DAHL explícita afirmação de que as assimetrias jurídicas aplicadas à estrutura da Federação podem guiar o processo de implantação e desenvolvimento democrático nos países que demonstram as condições assinaladas, um estudo detido sobre os escritos desse autor permite que se conclua nesse sentido. Por certo, alguns Estados compostos específicos, apesar de terem plasmados, em seus respectivos territórios, complicados pontos de tensão, conseguiram criar, dentro de parâmetros satisfatórios, instituições perenes e afinadas aos comandos democráticos, as quais são imprescindíveis para a acomodação das divergências regionais que sempre estiveram presentes na história de tais países. A concretização de iniciativas como a dos Estados Unidos, da Bélgica, da Suíça e do Canadá, hoje somente são exemplos de sucesso, graças à utilização de institutos jurídicos de diferenciação regional que se revelaram exitosos na compatibilização das adversidades.

Há de se notar, aqui, que todos os Estados aludidos são adeptos, em diferentes gradações, de ferramentas muito originais que conseguiram, por força de vários acordos de tolerância e de reciprocidade, permitir o surgimento de importantes arranjos institucionais. Nesse compasso, observa DAHL que, em muitas situações, não basta eleger a democracia como base de modelação do regime político, deve-se buscar também outros elementos que tornem viável a compatibilização das desigualdades observadas nas realidades defrontadas. Se não houver a junção de tais recursos, muito provavelmente a democracia e o federalismo, atuando cada qual em uma direção, serão insuficientes para garantir o respeito à diversidade e para potencializar a consecução de eficiência governamental.

Não é por acaso que, conforme assevera o autor, para que a democracia encontre condições propícias à sua implantação, desenvolvimento e permanência em cenários culturais marcantemente heterogêneos, ao menos um dos seguintes fatores deve estar presente: a) a "assimilação da nacionalidade"; b) a "tomada de decisões pelo consenso"; c) a "adoção de sistemas eleitorais garantidores da representatividade dos grupos minoritários"; d) a "separação territorial" 171 .

No que respeita à "assimilação da nacionalidade", o melhor exemplo são os Estados Unidos, onde, a despeito da enorme diferença populacional que integra o contingente humano daquele país, houve rápida e completa incorporação dos valores próprios da nação

${ }^{171}$ Cf. Robert A. DAHL, Sobre a Democracia, Ob. cit., pp. 166-173. 
estadunidense pelas gerações descendentes das correntes imigratórias. As raízes ancestrais dos imigrantes não constituíram obstáculo para que se formassem uma identidade nacional e uma vigorosa lealdade política, ambas ligadas aos padrões culturais, ideológicos e institucionais daquele Estado. Esse fenômeno se deu de modo a não negar o legado mínimo de cultura trazido pelos imigrantes, possibilitando a superposição dos valores estadunidenses sem, no entanto, eliminar aspectos importantes da identidade dos grupos minoritários estrangeiros.

A "tomada de decisões pelo consenso", por sua vez, é técnica interessante para países dotados de um emaranhado de culturas potencialmente divergentes, tal qual o é a Bélgica. Nesse Estado, os aparatos jurídicos e políticos elaborados para aferir a vontade nacional exigem unanimidade ou amplificado consenso nas decisões tomadas pela chefia do Estado e pelo Parlamento. Anote-se que isso é possível por força do reduzido território e da diminuta população do país, sendo que a vontade geral pelo consenso ou pela unanimidade permite que se atribua voz a pequenos grupos da sociedade, integrando-os no conjunto social e, dessa forma, evitando o fomento de propósitos contestadores ou separatistas.

Em Estados de territórios extensos e população numerosa, o consenso ou a unanimidade das decisões acaba sendo impraticável. Assim, para vencer esse obstáculo, sem, contudo, afastar-se das finalidades já esposadas em relação ao segundo fator, avulta a pertinência da "adoção de sistemas eleitorais garantidores da representatividade dos grupos minoritários". Em países que apresentam tais características, o planejamento de sistemas eleitorais em que, por exemplo, nenhum candidato poderá ser eleito com o apoio somente de um grupo cultural acaba sendo uma opção razoável. A obtenção de assentos legislativos depende, assim, da confiança dos votos de diversos segmentos que compõem a sociedade.

Por fim, a "separação territorial" - aspecto de maior interesse para o sistema federativo, notadamente para o federalismo assimétrico - é suscitada frequentemente nas situações em que as fendas culturais são profundas demais para serem superadas por quaisquer das soluções acima aventadas. Torna-se, então, aconselhável proceder à separação dos grupos sociais em diversas unidades territoriais dotadas de autonomia em nível suficiente para que haja identidade entre os grupos assentados e preservação das diversificadas culturas. O exemplo mais contundente desse fator é a Suíça, lugar em que o forte multiculturalismo exigiu a criação de cantões que congregassem parcelas de população com características socioculturais homogêneas (por exemplo: francófonos e 
católicos em uma unidade; germânicos e protestantes, em outra), cada qual adequado para lidar com as variadas questões de preservação e fomento das respectivas culturas.

Essas ponderações, quando consideradas sob a perspectiva do federalismo, refletem-se na verificação de que, hoje, os paradigmáticos modelos de democracias pacíficas não apenas se encontram arrimados em sistemas federativos, como também em arranjos assimétricos que asseguram convivência harmoniosa entre os diversos segmentos sociais. Esse fato, por sua vez, redunda na certeza de que, "por vezes, as exigências políticas de grupos culturalmente diferentes podem ser conciliadas reconhecendo, explicitamente, a diversidade de grupos e tratando regiões particulares de modo diferente de outras em matérias específicas" ${ }^{172}$. É inquestionável que a mera reunião de atores diferentes numa mesma organização estatal não é suficiente para trazer estabilidade e eficiência aos laços associativos existentes; se houver sérias disparidades regionais, o constituinte deverá criar fórmulas jurídicas de tratar esse ambiente potencialmente explosivo, haja vista que, do contrário, dificilmente as instituições políticas conseguirão ser permanentes e o próprio Estado poderá ruir.

Acerca da importância do federalismo assimétrico na disciplina de contextos de patentes diversidades, não é demais grifar que as técnicas de particularização constitucional das exigências regionais que acompanham a assimetria "podem, assim, conciliar algumas subunidades reconhecendo diferenças específicas nas suas estruturas políticas, administrativas e econômicas [...]. Isto permite maior flexibilidade para responder a exigências diferentes e conciliar a diversidade. Estas medidas especiais permitem que as diferenças do grupo territorialmente concentrado coexistam politicamente com a autoridade central, reduzindo assim choques violentos e exigências de secessão"173.

Entretanto, no afã de empregar as práticas de institucionalização da assimetria, é defeso agir prematuramente, sem antes mapear e conhecer com profundidade quais são os verdadeiros pontos de tensão do Estado federal que deverão ser remediados. É imperativo, assim, que a colocação em prática dessa teoria da assimetria não proporcione a criação de unidades etnicamente puras, o que, caso acontecesse, demonstraria cabal desapego aos primados da democracia e do compromisso de integrar as minorias ao conjunto nacional. A eventual criação de entes autônomos fechados ao pluralismo, em vez de selar o respeito à tolerância e ao pluralismo, certamente acabaria ocasionando o fatal isolamento dessas regiões que receberam tratamento assimétrico, apartando-as do conjunto.

\footnotetext{
${ }^{172}$ PNUD (Programa DAS Nações Unidas PaRa o DeSENVOLVIMENTO), Ob. cit., p. 51.

173 Idem, ibidem.
} 
A criação de Estados sob condições de intensas divergências de interesses regionais representa um convidativo canal para o início de conflitos e condutas predatórias entre as respectivas partes, e por isso deve existir permanente vigília para que práticas desse quilate não venham a ser ensaiadas. O ideal é, sem dúvida, assegurar a cada um dos entes competências específicas, na exata medida das capacidades de execução que esses possuírem ${ }^{174}$, cuidando-se sempre para evitar que o emprego de tais recursos de compatibilização não traga favoritismos ou protecionismos entre as diversas unidades da Federação ${ }^{175}$. De nada adianta estabelecer um sistema formalmente perfeito de competências, mas impossível de ser, na prática, exercitado por todos os entes de forma igualmente proveitosa.

Por oportuno, Augusto ZimmERMAnN adverte que os Estados compostos não podem ser reduzidos à condição de arquétipos de Estados unitários, porque a Federação rechaça tendências de padronização dos entes que a compõem. A complexidade dos cenários que aspiram ao êxito do regime federativo tanto no que concerne à eficiência governamental quanto em relação ao redimensionamento dos nefastos impactos causados pela diversidade requer a construção de modelos político-organizacionais flexíveis e abertos à aceitação das diferenças localizadas no vasto ambiente territorial. Daí porque é corrente defender que estruturas de poder que dificultam alcançar a igualdade e a liberdade dos entes federados - e, por conseguinte, dos indivíduos que neles habitam - são inapropriadas para servir ao Estado federal e para disciplinar todos os contrastes que naturalmente acompanham o federalismo ${ }^{176}$.

A par das considerações empreendidas, registre-se que a situação de colapso enfrentada por muitas Federações faticamente assimétricas resultou da inaplicabilidade dos engenhos constitucionais formulados, bem como do emprego de práticas mal-elaboradas, incongruentes e superficiais de acomodação da diversidade. Esse fato demonstra que a proposta do federalismo assimétrico - e todos seus consectários - não significa, por si só, um perigo à estabilização das heterogeneidades. Em abono a essa afirmativa, URSULA K. HICKS enfatiza o exemplo da Federação das Índias Ocidentais, originada em 1958, em virtude de forte influência britânica. A instauração desse Estado desconsiderou importantes

\footnotetext{
${ }^{174}$ Cf. Augusto Zimmermann, Ob. cit., p. 180.

${ }^{175}$ Cf. PNUD (Programa das NaÇões Unidas PARA O DESENVOlVimENTO), Ob. cit., p. 51.

176 Augusto ZimmermanN, Ob. cit., pp. 180-181.
} 
aspectos políticos e econômicos das unidades caribenhas envolvidas, e isso foi decisivo para sua curta duração (até o ano de 1962) ${ }^{177}$.

O que se busca com o federalismo assimétrico é a concretização no plano territorial da inequívoca vontade política de melhorar o funcionamento democrático do sistema de descentralização política. O valor mais elevado a ser observado é, portanto, a construção de um arcabouço apto a conciliar as diferenças mais sensíveis e passíveis de gerar o desmantelamento do Estado, ao mesmo tempo em que se busca permitir que se forme o sólido sentimento de lealdade nacional, tão importante para o desenvolvimento do universo federativo em todas as suas dimensões. Assim, ressalta JEAN-FrAnÇOIS GAUDREAULTDESBIENS que as normas que regem uma Federação jamais poderão fazer com que as desigualdades sejam amplificadas artificialmente, sob pena de haver a criação de meios inidôneos e prejudiciais a convívio dos entes autônomos ${ }^{178}$.

Para firmar-se como modelo operativo, o sistema federal precisa atingir com idêntica intensidade todo o território onde é empregado. Deve encontrar condições propícias para que ocorra um verdadeiro processo de "federalização", conforme sublinha MiQuel CAminAL, ainda que, para tanto, precise-se de ajustes e acomodações compensatórios das diferenças arraigadas às unidades federadas. A essencialidade do "equilíbrio entre as distintas unidades federadas, o que não implica igualdade simétrica" "179, adquire especial significado para a manutenção da ordem estabelecida em regiões que sofrem com conflitos de interesses regionais acentuados. Ainda que as assimetrias fáticas dentro dos Estados federais sejam naturais, tais aspectos não podem jamais ofuscar a noção de conjunto, nem desestabilizar o pacto federativo, o qual deverá estar baseado no difícil equilíbrio entre unidade e diversidade.

Nessa linha de entendimento, descuidar das especificidades apresentadas por parcelas do território dos Estados que optam pelo federalismo prejudica sobremaneira o encontro do desejado equilíbrio. Com isso, a Federação mostra estar deslocada dos preceitos essenciais da democracia, na medida em que o poder estatal, embora descentralizado, acaba não acudindo as demandas implacavelmente colocadas pelo cenário social de heterogeneidades. Em tais circunstâncias, o regime federativo não passará de um

\footnotetext{
${ }^{177}$ Cf. Ob. cit., pp. 55-67.

${ }^{178}$ Cf. Federalismo y Democracia, in Boletín Mexicano de Derecho Comparado, Nueva Serie, ano XXXIX, $\mathrm{n}^{\mathrm{o}}$ 117, sep./dic., 2006, p. 683.

${ }^{179}$ El Federalismo Pluralista: del Federalismo Nacional al Federalismo Plurinacional, Barcelona, Paidós, 2002, p. 175.
} 
embuste, uma promessa que nunca poderá ser concretizada, e estará instituído sempre distante do núcleo de valores que caracterizam essa forma de Estado.

O multiculturalismo, de fato, forçou o Estado federal a inovar-se. Entretanto, não foi a única força que desencadeou esse processo ${ }^{180}$. As exigências de atendimento às reivindicações de igualdade econômica e social - voltadas destacadamente à diminuição dos desníveis no padrão de vida da população e a forte intenção de se obter um desenvolvimento nacional integrado - foram relevantes para que a Federação passasse por obras de reengenharia nos últimos tempos. Suas ideias elementares foram preservadas, mas o sistema federativo vem sendo adaptado para conseguir atender as necessidades de mundo em constante transformação, que demonstra padrões, urgências e temores muito distintos daquele em que a noção de Estado federal foi inicialmente formalizada.

No Brasil, apesar de o federalismo não exigir maior atenção no tocante aos choques e entreveros derivados da diversidade cultural, o que aguarda premente tratamento são questões ligadas à desigualdade econômica e aos diferentes ritmos de desenvolvimento econômico das regiões. Por tal razão é que se conclui que o ponto de maior interesse para a Federação nacional é o desejo de utilizar a ordem constitucional já estabelecida para proporcionar a cada ente autônomo uma esfera de atuação governamental exequível e adequada $^{181}$. O pacto federativo deverá, portanto, traduzir com fidelidade as reais condições e capacidades suportadas pelas unidades federadas, e nessa empreitada não haverá como dispensar o emprego das técnicas e das proposições do federalismo assimétrico, pois a diversidade que dimana do meio social prova que, se existe uma constante entre nossos entes, é justamente a disparidade de uns em relação aos outros.

Diante dos inúmeros reflexos que a assimetria jurídica certamente causa nas instituições políticas que definem o Estado brasileiro, considerando-se ainda a importância

\footnotetext{
${ }^{180}$ Integram essa percepção as considerações de MiguEL REALE no sentido de que a Democracia Social não pode ser traçada em um modelo ou figurino uniforme para todo e qualquer país e toda e qualquer época, o que implica necessariamente a impossibilidade de transplante, sem traumas, de sistemas políticoorganizacionais de um Estado para outro. A principal razão responsável pela rejeição de protótipos funcionais em outras realidades políticas está no fato de que essa transposição automática de estruturas leva à desconsideração das peculiaridades de cada comunidade, de cada nação, negando-se a singularidade de povos específicos. A respeito dessa problemática, estatui REALE: "Muito embora, por conseguinte, a Democracia Social possua alguns princípios básicos, como aqueles a que fiz referência (princípios esses que conferem à Democracia não apenas legitimidade jurídica, mas também legitimidade social ou cultural) preciso é reconhecer que eles não podem deixar de se adequar, de maneira plural, a distintas estruturas nacionais. Cada povo, de certa maneira, através de sua própria experiência, não pode deixar de realizar as fórmulas e esquemas correspondentes à sua situação quer histórica, quer social, quer econômica. Mesmo porque, como já adverti, os índices de participação do Estado e do indivíduo - que é um processo de mão dupla - variam segundo a situação em que o processo produtivo é posto em cada nação", Da Democracia Liberal à Democracia Social, in Revista de Direito Público, $\mathrm{n}^{\circ} 71$, p. 30.

${ }^{181}$ Cf. Augusto Zimmermann, Ob. cit., p. 180.
} 
de não negligenciar tratamento às complicadas desigualdades regionais sempre presentes na história de nossa Federação, convém empreender estudo de algumas experiências estrangeiras de sucesso na diferenciação compensatória dos entes federados com o objetivo de disciplinar as disparidades regionais. De fato,a lguns Estados conseguiram fazer com que disposições em seus respectivos textos constitucionais, bem como algumas práticas governamentais institucionalizadas, assumissem o papel de importantes ferramentas na correção das problemáticas disparidades que se explicitam no funcionamento do sistema de descentralização político-territorial de poder.

Embora seja inquestionável que as heterogeneidades existem e causam problemas nos Estados compostos, muitos regimes de descentralização política ainda não se atentaram para a relevância de cuidar desse aspecto estrutural. A imprescindibilidade de utilizar os mecanismos ligados ao federalismo assimétrico é explicitada, sobretudo, em relação aos contextos fáticos em que as patentes disparidades internas representam causa impeditiva para a disseminação dos desejos coletivos de democracia e de respeito à diversidade em todas as suas formas de expressão. Desse modo, considerando-se tais verificações, a parte seguinte deste trabalho traz uma breve análise dos principais instrumentos aplicados nas organizações estatais sabidamente assimétrica.

\section{II.3. A Experiência Assimétrica nas Federações Contemporâneas: Apontamentos de Direito Comparado na Acomodação das Desigualdades Regionais}

Nos últimos tempos, alguns Estados compostos têm feito da engenharia constitucional uma destacada peça de correção das disparidades regionais e de pacificação dos ânimos de setores expressivos da sociedade. Essa constatação, além de ser figurar como incalculável estímulo àqueles que entendem que os instrumentos jurídicos e o permanente diálogo são os mais indicados meios para a consecução de níveis satisfatórios de tolerância e de progresso social, atribui também grande importância ao formato das instituições políticas que estruturam a organização estatal, na medida em que atesta que as mesmas devem sempre ser desenhadas de modo a trazer equilíbrio entre as forças que, em tese, podem desestabilizar a unidade do Estado. Dessa forma, torna-se inegável que os estudos comparatísticos de Direito podem servir como técnica de muita serventia no planejamento das estruturas que garantem a subsistência e o aperfeiçoamento do Estado nacional, por isso é que a referência a alguns aspectos dessa ciência, bem como a outros 
ordenamentos jurídicos, não podem faltar quando os temas em questão são a acomodação da diversidade e o federalismo assimétrico.

Em primeiro lugar, precisam ser aportadas alguns notas sobre o método observado e os resultados que podem ser tirados com a manipulação da referida técnica. Registre-se que, dentre as várias funções que podem ser conferidas ao Direito Comparado, duas foram de especial significado para a proposta aqui lançada. São elas: a utilização dos estudos comparatísticos no auxílio da interpretação da norma constitucional e como fonte de inspiração na elaboração de institutos jurídicos adequados à realidade de determinado Estado $^{182}$. Sem dúvida, apenas esses propósitos já justificariam um estudo separado sobre a assimetria nas Federações; entretanto, o que se pretende, na medida do possível, é explicitar quais avanços que o Estado federal brasileiro poderia ter se as iniciativas de sucesso no estrangeiro fossem adaptadas pelo país, respeitadas as condições e necessidades, inseridas na órbita de nosso constitucionalismo.

Ainda sobre a finalidade precípua do Direito Constitucional Comparado, PAOLO BISCARETTI DE RUFFIA explica que o maior valor dessa ciência está no fato de que o conhecimento das estruturas constitucionais de países similares pode ser extremamente útil para a criação de novas normas jurídicas. O estudo comparatístico permite a obtenção de melhor técnica, pois possibilita extrair, da experiência estrangeira já concretizada, conclusões acerca da viabilidade ou não de determinado instituto jurídico para a realidade nacional. Em outras palavras, vale admitir que os resultados da investigação jurídica comparada podem constituir salutar orientação para o desenvolvimento das instituições de Direito, além de se apresentarem como limite às fantasias do legislador ${ }^{183}$.

O amparo nos domínios do Direito Comparado deve ser corrente em nossa época, pois as normas jurídicas não representam somente mecanismos de estabilização social, mas fatores de transformação da realidade onde são aplicadas ${ }^{184}$. Daí faz sentido estudar institutos de Direito estrangeiro que possam, efetivamente, ser transpostos para a realidade de um país que deseja passar por transformações que lhe tragam progressos. A certeza de

${ }^{182}$ Cf. GiusepPe De Vergottini, Diritto Constitucionale Comparato, $2^{\mathrm{a}}$ ed., Padova, CEDAM, 1987, pp. 1221. São essas atribuições que permitem Ivo DANTAS afirmar que ao Direito Comparado aplicam-se as mesmas funções da Ciência Jurídica, pois deve ser ele ferramenta de "interpretação, sistematização e construção" das normas constitucionais, Direito Constitucional Comparado, vol. 1, $2^{\mathrm{a}}$ ed., Rio de Janeiro, Renovar, 2006, pp. 102-103.

${ }^{183}$ Cf. Introducción al Derecho Constitucional Comparado y 1988-1990. Um Trienio de Profundas Transformaciones Constitucionales en Ocidente, em la URSS y los Estados Socialistas del Leste Europeu, México, Fondo de Cultura Económica, 1996, p. 80. Ver também Lucio Pegoraro, El Método en el Derecho Constitucional: la Perspectiva desde el Derecho Comparado, in Revista de Estudios Políticos (Nueva Época), no 112, abr./jun. 2001, pp. 16-18; e PETER HÄBERLE, Ob. cit., pp. 172-174.

${ }^{184}$ Cf. René David, Ob. Cit., p. 7. 
que o conteúdo das relações políticas e sociais poderá ser, na essência, modificado por meio do acertado emprego de instrumentos jurídicos condiciona o interesse para incursões investigativas em outras ordens constitucionais ${ }^{185}$.

No que respeita ao federalismo assimétrico o campo de estudo disponibilizado ao Direito Comparado é inesgotável, já que, como anota DirCÊO TORRECILlas RAMOS, “a simetria e a assimetria apresentam-se de várias maneiras. As distorções podem ser de Estado para Estado ou entre regiões como nos Estados Unidos e no Brasil. Poderá ocorrer por necessidades de um federalismo étnico como o caso da Nigéria. Outras hipóteses são a questão das nacionalidades e elites, como na Espanha; da acomodação linguística como na Índia; problemas de finanças na Suíça ou, ainda, as uniões internacionais" ${ }^{186}$. Pelo que se depreende, impossível não encontrar elementos de assimetria nos Estados compostos, razão pela qual o que interessa é identificar institutos político-constitucionais já adotados por outros ordenamentos e que exitosamente conseguiram se afirmar e corrigir os desníveis regionais antes problemáticos.

Por conta da premência e da importância que a temática das disparidades entre as unidades autônomas representa para o Estado brasileiro e considerando-se, ainda, que as melhorias em matéria de governabilidade em Federações heterogêneas dependem, obrigatoriamente, da correção dos impasses que se formam na execução do pacto federativo, é que se traz ao estudo referências ao Direito Comparado. Essa orientação acaba confirmada por JOSÉ AFONSO DA SILVA, que consigna a relevância que o Direito Comparado assume para os movimentos constitucionais de reforma do Estado. A comparação, segundo considera, pode revelar que outras Constituições resolvem os mesmos problemas por instituições mais apropriadas ou mais simples, o que pode levar à compreensão de que as práticas ou os órgãos nacionais encontram-se ultrapassados. Além disso, ao facilitar a compreensão do Direito pátrio, o método comparatístico permite a efetivação de reformas seguras nas instituições políticas internas, mormente porque poderão ser ponderados os aspectos de aceitação e de descarte de modelos estrangeiros já

185 Cabe assinalar que esse é o posicionamento sugerido por José AlFREDO DE OLIVEIRA BARACHO à Assembleia Nacional Constituinte durante os trabalhos desenvolvidos pela Subcomissão dos Estados, na $7^{\mathrm{a}}$ Reunião Ordinária ( $3^{\text {a }}$ Reunião de Audiência Pública), realizada em 29 de abril de 1987. Na ocasião, ficou enfatizado que "temos de tomar a experiência de outros Estados, mas adaptá-la a determinadas condições inerentes à realidade brasileira e construir, desta vez, um autêntico federalismo. Em diversas fases procuramos ver o federalismo americano, o federalismo cooperativista, o federalismo dualista, o federalismo científico, como ideias para reformular o federalismo brasileiro. Vamos ver essas experiências, mas vamos também observar a realidade brasileira para composição de um federalismo que seja lúcido para a Constituição de 1987', Diário da Assembleia Nacional Constituinte (Suplemento), Subcomissão do Estado, Brasília, Senado Federal, Centro Gráfico, 1987, p. 57.

${ }^{186}$ Ob. cit., pp. 60-61. 
institucionalizados, projetando-os sobre o conjunto das instituições de nosso Estado, com o objetivo de aferir indícios de harmonização e de funcionalidade ${ }^{187}$.

Esquadrinhadas, em apertada síntese, as considerações sistematizadoras da comparação constitucional, são analisados abaixo os modelos assimétricos eleitos como os mais próximos de viabilizarem melhorias estruturais ao Estado brasileiro. Convém repisar a imprescindibilidade de realizar-se criteriosa adaptação dos institutos e dos paradigmas estrangeiros ao quadro constitucional de nosso país, conformando-os às aspirações depositadas na Federação não somente pelo constituinte, mas também pela sociedade nacional como um todo. Independentemente das alterações que venham a ser realizadas nas estruturas da Federação, é fundamental ter em vista que o pacto federativo deverá, de modo obrigatório, permitir a incorporação de conteúdos sociais na atuação dos governos periféricos e central, sob pena de, com muita probabilidade, atitudes negligentes nesse sentido resultarem na perpetuação das desigualdades, tanto interpessoais quanto interregionais $^{188}$.

\section{II.3.1. O Estado Federal Canadense: a Cooperação e a Coordenação como Recursos Voltados à Preservação da Diversidade.}

Impossível enfrentar o tema da assimetria federativa e deixar de tratar, ainda que brevemente, da Federação canadense e de como esse Estado, culturalmente heterogêneo, consegue manter-se coeso e harmônico. O sistema de descentralização política do país recebe expressivos cuidados do Direito Comparado porque, conforme observa AlaIN-G. GAGNON, nele convivem influências tanto da matriz estadunidense de Federação, que prima pela unidade do conjunto, quanto das tradições européias de elaboração de pactos federativos, estas enaltecedoras da diversidade dos entes federados ${ }^{189}$. E é por isso que o Canadá recebe o predicado de ser "um laboratório único" 190 para estudos comparatísticos sobre a forma federativa, pois lá convivem tendências divergentes e que, geralmente, não conseguem ser tão bem compatibilizadas em outros Estados compostos.

\footnotetext{
${ }^{187}$ Um Pouco de Direito Constitucional Comparado (Apêndice: Três Projetos de Constituição), São Paulo, Malheiros. 2009, pp. 46-47. Igual entendimento é pactuado por AfOnSO ARINOS DE MELO FrANCO, Ob. cit., p. 36.

${ }^{188}$ Cf. Rui de Brito Álvares AfFonso, A Federação na Encruzilhada, in Rumos: Caminhos do Brasil em Debate: Quem és tu, Federação? (publicação da Comissão Nacional para as Comemorações do $V$ Centenário do Descobrimento do Brasil), São Paulo, ano 1, n 2, mar./abr. 1999, p. 38.

${ }^{189}$ Cf. Quebec y el Federalismo Canadiense, Ob. cit., p. 24.

${ }^{190}$ Idem, ibidem.
} 
O Canadá apresenta não somente assimetrias de fato (o que obviamente ocorre em todas as Federações), mas também várias assimetrias jurídicas. Significativos mecanismos de compensação da diversidade interna marcam o pacto federativo daquele país e encontram expressa positivação na Constituição Federal. Esse dado chama a atenção de muitos Estados compostos que visualizam nas formulações jurídicas a solução para vencer os fatores de desagregação da unidade federativa. Para que se entenda o quadro de organização do Estado canadense, focalizando-se as assimetrias de jure existentes, é interessante considerar dois períodos da história constitucional do Canadá: o primeiro iniciado em 1867 e estendido até a década de 50 do século XX; e o outro, correspondente aos anos posteriores a 1960, sendo este denominado de época da política megaconstitucional ${ }^{191}$.

Em relação ao primeiro período da histórica constitucional da Federação canadense, vale pontuar que o ano de 1867 corresponde ao marco do surgimento do federalismo naquele país. Nesse ano houve a edição, pelo Parlamento britânico, do The British North America Act, documento jurídico que descreveu as disposições do Poder Executivo, Legislativo e a legislação fiscal, além de ter disciplinado o direito de as províncias terem cada qual sua própria Constituição regional ${ }^{192}$. Essa competência assegurada aos entes federados - para que, já nos primeiros anos de funcionamento da Federação, as partes periféricas pudessem cuidar de seus respectivos interesses -, foi essencial à convivência, sob uma mesma ordem constitucional, de canadenses de origem francesa e dos canadenses de origem inglesa, cada segmento alocado em parcelas muito bem definidas do território $^{193}$.

${ }^{191}$ Cf. DirCÊO ToRRECILlas RAmos, O Federalismo Assimétrico, Ob. cit., p. 121; e Ronald L. WATTS, The Canadian Experience with Asymmetrical Federalism, in Accommodating Diversity: Asymmetry in Federal States, Robert Agranoff (ed.), Ob. cit., p. 118.

${ }^{192}$ Cf. Janice Helena FerReri Morbidelli, Um Novo Pacto Federativo para o Brasil, São Paulo, Celso Bastos Editor, Instituto Brasileiro de Direito Constitucional, 1999, p. 66. Sobre o documento jurídico que inaugurou o Estado federal no Canadá consultar Denise Helly, Primacía de los Derechos o Cohésion Social: los Limites del Multiculturalismo Canadiense, in Acciones e Investigaciones Sociales, $\mathrm{n}^{\mathrm{o}} 15$, out. 2002, pp. 7-12.

${ }^{193}$ RONALD L. WATTS retrata a situação do Canadá que levou à adoção do federalismo assimétrico, explicando que "a característica mais proeminente da Federação canadense é a permanência e a vitalidade dos nacionais franceses daquele Estado que estão concentrados majoritariamente em uma província. Aproximadamente $80 \%$ da população francófona do Canadá vive em Quebec, onde eles constituem mais de $80 \%$ da população. Durante sua existência histórica esse Estado federal foi marcado pela dualidade franceses-ingleses e por um vigoroso regionalismo expressado pelas províncias. Mais recentemente iniciouse também a discussão acerca do espaço a ser assegurados aos povos aborígenes na Federação", Comparing Federal Systems, Ob. cit., p. 24. Anote-se ainda que os cuidados dispensados a Quebec pelo texto constitucional fez com que PINTO FERREIRA categorizasse a Federação do Canadá como a manifestação de um "federalismo hegemônico", pois o autor visualizava no tratamento assimétrico "a supremacia de alguns Estados-Membros sobre outros", Cf. Curso de Direito Constitucional, $7^{\mathrm{a}}$ ed., São Paulo, Saraiva, 1995, p. 275 . 
Apenas garantir o poder de auto-organização às províncias mostrou ser insuficiente para a manutenção da coexistência harmônica entre as unidades federadas, porque, consoante anota JOSÉ WOEHRLING, os anglófonos estavam maciçamente presentes em três das quatro províncias reunidas pela Lei 1867 (Ontário, Nova Bruwswick, Nova Escócia), ao passo que os francófonos ficaram, em sua maioria, reunidos em apenas uma dessas províncias: Quebec. Foi justamente a condição diferenciada de Quebec o elemento determinante para que os construtores da Federação canadense buscassem formas de conciliar o caráter particularizado desta unidade, pois havia a consciência de que as especificidades quebequenses não poderiam impedir a concretização do postulado da igualdade das partes autônomas que integravam aquele Estado ${ }^{194}$.

Os aspectos particularizantes da província de Quebec não podem ser resumidos apenas na questão do idioma francês, em traços culturais próprios, no emprego do sistema da Civil Law em matéria de disposição do ordenamento jurídico, nas instituições sociais e na grande dissensão histórica em relação ao resto do Estado, já que há também o que RONALD L. WATTS denomina de "ideologia de sobrevivência" dos valores cultuados pelos canadenses de ascendência direta francesa ${ }^{195}$. De acordo com WATTS, essa ideologia desempenhou relevante influência na conformação do Estado federal do Canadá, na medida em que representou uma consistente espécie de assimetria de fato por meio da qual Quebec, desde a institucionalização dos laços federativos, conseguiu pressionar permanentemente a Federação para obter, nas últimas três décadas, a consagração constitucional de ajustes político-jurídicos que acomodassem de forma satisfatória todas as diferenças culturais, linguísticas e sociais da província.

Assim, afirma-se que, entre o final do século XIX e até aproximadamente 1960, o federalismo canadense esteve muito longe de conseguir atenuar por si só os impulsos de fragmentação dos seus segmentos. Na verdade, o The British North America Act ocultou conflitos entre identidades coletivas que estavam latentes no contexto daquele país. Isso fez com que a intenção de criar uma nação única, suficientemente alicerçada e que causaria o desaparecimento das identidades britânica e francesa - tal qual desejavam os primeiros

${ }^{194}$ Cf. El Principio de Igualdad, el Sistema Federal Canadiense y el Carácter Diferencial de Quebec, in Asimetría Federal y Estado Plurinacional: el Debate sobre la Acomodación de la Diversidad en Canadá, Bélgica y España, Enric Fossas y Ferran Requejo (Eds.), Ob. cit., p. 143.

${ }^{195} \mathrm{Cf}$. The Canadian Experience with Asymmetrical Federalism, in Accommodating Diversity: Asymmetry in Federal States, Robert Agranoff (ed.), Ob. cit., p. 119. Em igual direção, Dircêo Torrecillas Ramos, $O$ Federalismo Assimétrico, Ob. cit., pp. 124-125. 
idealizadores do Canadá -, não tomasse contornos concretos porque as aspirações nacionalistas ofuscaram esse desejo ${ }^{196}$.

Como não poderia deixar de ser, as fortes assimetrias de fato condicionaram, ao longo do tempo, o aparecimento de movimentos de pressão voltados a pleitear o reconhecimento de diferenciações fundamentadas em documentos jurídicos. DIRCÊO TORRECILlas RAmOS esclarece que, já em 1867, o Ato de Constituição trouxe algumas assimetrias, cujo conteúdo versavam sobre a previsão de um sistema de direito baseado na Civil Law e de mecanismos governamentais de promoção da língua francesa, apenas para Quebec (seção 129); possibilidade de o poder central destinar subsídios diferenciados para as províncias com base nas seções 118 e 199; além de permissão constitucional para que, em nome do equilíbrio regional, a representação das províncias pudesse ser desigual no Senado (art. 22) ${ }^{197}$. Essas medidas diferenciadoras, embora justificáveis diante da disparidade sociocultural que marca aquele país, não ficaram imunes a correntes oposicionistas e foram essas tensões que, hoje, são entendidas como as principais responsáveis pela configuração do regime federativo lá estruturado.

O segundo momento da evolução do Estado federal canadense, vivenciado após 1960 e chamado de período da política megaconstitucional, fez com que ganhasse projeção as desencontros de posicionamentos políticos defendidos pelas províncias. De um lado, encontra-se Quebec a propagar que uma centralização maior do sistema seria o caminho para a obtenção de direitos uniformes e para o sucesso de programas sociais. Por sua vez, as demais províncias rechaçam esse entendimento de que ao governo federal seria interessante atribuir maiores poderes, pois, assim, as assimetrias federativas poderiam ser acomodadas pela atuação do poder central ${ }^{198}$.

Mais uma vez, vale recorrer aos ensinamentos de DIRCÊO TORRECILLAS RAMOS para compreender a disposição do cenário político canadense a partir da segunda metade do século XX. Com precisão, explica ele que muitos dos debates constitucionais ocorridos recentemente buscam acomodar três gêneros do princípio da igualdade: "igualdade dos cidadãos como simbolizada pela Constituição, igualdade das províncias, advogada muitas vezes pelos primeiros ministros provinciais e igualdade de dois povos linguísticos,

\footnotetext{
${ }^{196}$ Cf. Alain-G. Gagnon, Quebec y el Federalismo Canadiense, Ob. cit., p. 163.

${ }^{197}$ Cf. $O$ Federalismo Assimétrico, Ob. cit., p. 127.

${ }^{198}$ Cf. DirCÊO TORRECILlas RAmOS, O Federalismo Assimétrico, Ob. cit., pp. 129-130. Confirma essa ideia José Woehrling, El Principio de Igualdad, el Sistema Federal Canadiense y el Carácter Diferencial de Quebec, in Asimetría Federal y Estado Plurinacional: el Debate sobre la Acomodación de la Diversidad en Canadá, Bélgica y España, Enric Fossas y Ferran Requejo (Eds.), Ob. cit., p. 145.
} 
defendida por nacionalistas dentro de Quebec"199. Os episódios desenrolados nesse curto espaço de tempo evidenciam que as propostas de institucionalização de assimetrias saíram vitoriosas.

$\mathrm{Na}$ verdade, os fatores que diferenciam o regime federativo aqui apreciado somente foram possíveis porque as instituições ligadas à descentralização do poder político demonstraram habilidade em combinar demandas funcionais de ordem geral e aspirações regionais. O pacto político formado convergiu para a garantia de uniformidade de condições entre as províncias, ao fazer com que a coordenação intergovernamental eliminasse qualquer sinal de hieraquização dos entes autônomos e, ao mesmo tempo, respeitasse as individualidades de condições de cada um dos atores governamentais. As interações entre o poder central e as unidades subnacionais mostraram-se fundadas em relacionamentos orientados por respeito mútuo ${ }^{200}$.

Nesse sentido, JANICE Helena FERRERi MorbiDelli observa que "a análise da dinâmica federal canadense permite afirmar que o modelo evoluiu para as negociações intergovernamentais. As relações entre os dois níveis de governo desenvolveram-se por meio de políticas de coordenação, visando reduzir os desequilíbrios regionais, garantido a integração e o desenvolvimento. O pacto federativo de concepção interestatal favoreceu esse encaminhamento, pois coube à União, prioritariamente, o exercício de funções mais gerais de planejamento e de coordenação global e às províncias autônomas a administração de assuntos de interesse local"201.

O Canadá é, por sua ímpar formação sociopolítica, um excelente exemplo de que o federalismo assimétrico é possível. Tomando-se em consideração o emblemático caso de Quebec, que, como assinalado, possui não somente seu próprio Direito Civil, mas conquistou nos últimos anos autonomia para cuidar de matérias ligadas à imigração, relações internacionais, renda e regime de pensão, situação essa resultante de intensas negociações com o governo federal. Além da unidade provincial que congrega a maioria dos francófanos, outras dez províncias também receberam tratamento diferenciado, na medida em que foram autorizadas a confiar seus serviços policiais a um organismo federal, a Real Polícia do Canadá. Essas referências são contundentes na demonstração de que a linha divisória entre a instância federal e governo provincial varia para cada uma desses

${ }^{199}$ Idem, pp. 129-130.

200 Cf. Janice Helena Ferreri Morbidelli, Um Novo Pacto Federativo para o Brasil, Ob. cit., p. 132. Posição contrária é tomada por ALAIN-G. GAGNON, especialmente no que diz respeito a Quebec, província que estaria encontrando, na atualidade, sistemáticas resistências do governo central no exercício do direito de autodeterminação de seu povo, Quebec y el Federalismo Canadiense, Ob. cit., pp. 217-222.

${ }^{201}$ Um Novo Pacto Federativo para o Brasil, Ob. cit., p. 134. 
entes, de maneira que, na prática, eles não têm os mesmos poderes executivos, legislativos e, em alguns casos, nem mesmo tratamento constitucional ${ }^{202}$.

\section{II.3.2. O Estado Regional da Espanha: A Heterogeneidade Materializada na Concessão de Estatutos Especiais}

A solução federalista para a organização do Estado espanhol é, peremptoriamente, afastada por JUAN FERRANDO BADIA, que defende a conveniência de adotar-se, naquele país, o modelo regional de descentralização política. Conforme entendimento capitaneado pelo aludido autor, a região é uma entidade pública territorial dotada de autonomia legislativa, sendo que a definição dos traços caracterizadores dessa figura não se faz pela aplicação de critérios tecnocrátivos, mas em virtude da confluência de fatores de natureza social e comunitária, já que as regiões perfazem, em essência, uma realidade geográficohistórica. São, portanto, áreas delimitadas territorialmente onde a vida em comum se desenvolve, e esse dado é determinante para que haja conciliação entre as exigências atuais de governabilidade e os pontos de tensão ligados às tradições e aos valores cultuados pelas entidades regionais $^{203}$.

A título elucidativo, explica Jorge MiRANDA que a concepção constitucional de Estado regional é relativamente recente, remontando à Constituição espanhola de 1931 e à italiana de $1947^{204}$. Anote-se ainda que, apesar de existirem fortes divergências sobre o preciso enquadramento do regionalismo no rol dos Estados unitários ou dos Estados compostos, alguns aspectos definidores de seus contornos jurídico-institucionais encontram-se sedimentados, ganhando destaque, aqui, o fato de que podem haver Estados regionais integrais, quando todo o território é dividido em regiões autônomas; e regionalismos parciais, verificados em organizações estatais que contam com algumas regiões politicamente autônomas e outras regiões ou circunscrições que apenas possuem descentralização administrativa ${ }^{205}$. Como se pode deduzir, reside nesse ponto significativa diferença entre o Estado regional e o Estado federal, pois esta forma estatal somente se dispõe na modalidade integral, haja vista que todos os seus integrantes (os entes federados), indistintamente, são titulares de autonomia política.

\footnotetext{
202 Cf. StÉPhane DiOn, El Federalismo Fuertemente Asimétrico: Improbable e Indeseable, in Asimetría Federal y Estado Plurinacional: el Debate sobre la Acomodación de la Diversidad en Canadá, Bélgica y España, Enric Fossas y Ferran Requejo (Eds.), Ob. cit., p. 197.

${ }^{203}$ Cf. El Estado Unitario, el Estado Federal y el Estado Autonomico, Madrid, Tecnos, s/d., pp. 144-145.

${ }^{204}$ Cf. Teoria do Estado e da Constituição, Rio de Janeiro, Forense, 2007, p. 301.

${ }^{205}$ Cf. Idem, p. 302.
} 
Ainda no que concerne à tipologia do Estado regional, JORGE MIRANDA aponta outro critério de interesse para a compreensão das assimetrias, trata-se da distinção estabelecida entre o Estado regional homogêneo e o Estado regional heterogêneo. Neste caso, o foco de análise está especificamente no tratamento jurídico que rege a organização das regiões, de modo que a homogeneidade pressupõe uniformidade na concessão de autonomias regionais e a heterogeneidade está lastreada na diferenciação das unidades regionais, o que faz com que hajam regiões de estatuto comum e regiões de estatuto especial. O exemplo categórico de regionalismo heterogêno é a Espanha que, sabidamente, conta com comunidades autônomas dotadas de regimes jurídicos diversos ${ }^{206}$.

Frente às espécies de regionalismo apresentadas (Estado regional integral ou parcial; e Estado regional homogêneo ou heterogêneo), uma conclusão mostra-se inevitável: a de que, onde houver regionalismo parcial e regionalismo heterogêneo, também existirão assimetrias jurídicas ${ }^{207}$. A verificação desse aspecto é crucial para justificar o interesse no estudo da conformação constitucional da oganização estatal espanhola, haja vista que, naquele país, foi atribuído o estatuto de comunidades autônomas ao País Basco, Catalunha, Galícia e a mais catorze outras entidades, o que significou a concessão de uma ampla e variável gama de poderes de autogoverno em áreas como a cultura, educação, língua e economia ${ }^{208}$. A disposição das regiões autônomas da Espanha denota o inegável compromisso difundido naquele país de fazer com que as técnicas de acomodação das diversidades territoriais convertam-se em fatores que proporcionem coesão política e mitigação dos ânimos mais exaltados de algumas das unidades do Estado.

Os desdobramentos desse ajuste político-constitucional retrata ainda que as três regiões acima referidas nominalmente obtiveram competências particularizadas para o exercício das prerrogativas decorrentes da autonomia e do autogoverno em função de aspectos históricos próprios. Outros dois atores políticos, o País Basco e Navarra, receberam, como alternativa tendente a apaziguar conflitos internos e pretensões separatistas, poderes fiscais e de executarem investimentos explícitos, os quais vão além das competências conferidas a outras comunidades autônomas. Numa escala macroestrutural, a Espanha certifica hoje que as medidas compensatórias introduzidas em seu interior foram salutares para a aceitação de múltiplas identidades culturais, o que fez com a autoridade central passasse a integrar cada vez mais setores do Estado hispânico

\footnotetext{
${ }^{206}$ Cf. Idem, ibidem.

${ }^{207}$ Cf. Idem, ibidem, nota 17.

208 Cf. PNUD (Programa das NaÇÕES Unidas PARA O DESENVOlVIMENTO), Ob. cit., p. 51.
} 
antes ignorados no que diz respeito às necessidades próprias apresentados pelos $\operatorname{mesmos}^{209}$.

Ainda sobre os mecanismos que regem a interação a autoridade nacional e os govenros perféricos, CARLES RAMIÓ e MIQUEL SALVADOR entendem que essa relação pode ser simbolizada pela interdependência que, em matéria de governabilidade, há entre a Constiuição e os Estatutos de Autonomia - estes significando leis básicas que regulam a organização institucional e as competências das comunidades autonômicas. Enfatizam que tal sistema aplicado na Espanha está arrimado em um conjunto de regras constitucionais que definem uma geometria variável de descentralização, o que se dá por meio de duas vias de acesso à autonomia. A primeira aplica-se aos três territórios com nacionalidades históricas (Catalunha, País Basco e Galícia) e, também, à Andaluzia, garantindo-lhes o máximo de competências. A segunda via, por seu turno, é seguida pelas demais regiões que, de alguma forma, tiveram suas especificidades reconhecidas pelos respectivos Estatutos de Autonomia; e, não obstante a conquista que lograram, receberam autonomia em um grau mais restrito, se comparado com o quantum atribuído às entidades do primeiro grupo $^{210}$.

Vale registrar que a situação das regiões enquadradas no rol das entidades que receberam autonomias em intensidade menos expressiva é, atualmente, considerada transitória, haja vista que elas têm buscado negociar com o poder central o aumento de suas competências, o que é feito, em geral, por meio de revisão de seus Estatutos de Autonomia. A revisão nem sempre é o único procedimento empregado para transferir ou delegar competências legislativas às comunidades autônomas, pois as Cortes Gerais (órgãos equivalentes ao Legislativo estadual no regime federativo) também podem assim proceder, o que, na prática, dispensa os atos revisionais e configura um sistema de concessões marcado por um nítido cárater político. Essa última técnica foi adotada com as comunidades Valenciana e das Ilhas Canárias.

Percebe-se, sem muita dificuldade, que o sistema espanhol de descentralização política traz, em seu bojo, ampla possibilidade de emprego das diferenciações jurídicas, no entanto, sua execução é de extremada dificuldade, por ser ele muito complexo e adepto tanto de assimetrias estruturais quanto de assimetrias relacionais. Essa característica não escapou ao crivo de DIRCÊO TORRECILLAS RAMOS, que distinguiu as assimetrias naquele

\footnotetext{
${ }^{209}$ Cf. Idem, ibidem.

${ }^{210}$ Cf. O Processo de Descentralização Regional na Espanha e as Dificuldades para Inovação Institucional das Novas Administrações Públicas, in Democracia, Descentralização e Desenvolvimento: Brasil e Espanha, Sonia Fleury (org.), Ob. ci., p. 241.
} 
Estado com base em dois critérios principais, a saber: diferenciações determinadas pela riqueza e pelos índices de desenvolvimento econômico de suas regiões; e diferenciações de direito condicionadas por fatores étnicos, culturais e históricos, estas operacionalizadas, especialmente, pelas assimetrias de caráter estrutural ou competencial ${ }^{211}$. $\mathrm{O}$ autor complementa ainda que, numa visão panorâmica, a experiência estatal lá empreendida reveste-se do caráter de "um modelo de 'múltipla concorrência etnoterritorial' que relaciona mobilização subestatal com relacionamento competitivo entre regiões e nacionalidades espanholas na perseguição de poder político e econômico, tanto quanto da legitimação de seus desenvolvimentos institucionais" 212 .

Ao que tudo indica, parece improvável que a Espanha abandone sua vertente regionalista para render-se ao modelo de ordenação político-territorial reproduzido pelas Federações. JOSÉ RAMÓN RECALDE é bastante preciso ao destacar que o mais contundente empecilho à adoção do federalismo no ambiente político espanhol é a impossibilidade de instituir-se mecanismos técnicos de descentralização que sejam habilitados a preservar o sentimento de comunidade, tão caro às regiões autonômas, formado ao longo dos tempos. Desse modo, é indicado fortalecer a atuação de tais regiões, objetivando fazer com que as unidades se vinculem à ideia de fidelidade constitucional, o que permitiria a obtenção de concertos constitucionais mais arrojados e funcionais, na medida em que as regiões passariam a compreender a importância de tolerar a diversidade de suas congêneres para atender o interesse do Estado, considerado como um todo ${ }^{213}$

Depois de apontadas as linhas que, genericamente, identificam o Estado Regional espanhol, fica explícito que essa organização estatal tem muitos pontos distintivos em relação ao Brasil. De fato, o Estado brasileiro, adepto do federalismo, não se encontra ameaçado pelos mesmos impasses que fragilizam a Espanha, já que aqui as assimetrias não devem buscar a correção de questões concentradas em divergências históricas e étnicas, por exemplo. Entretanto, a análise das soluções encontradas na Espanha, com a edição de Estatutos de Autonomia diferenciados para as diversas regiões, pode ser proveitoso para que o regime federativo nacional encontre inspirações para resolver parte de seus problemas ligados à heterogeneidade territorial que toma conta de nosso país.

Por certo, o sucesso com o qual o governo espanhol vem acomodando as diferenças entre suas regiões - notadamente, valendo-se tanto de acordos políticos baseados no

${ }^{211}$ Cf. O Federalismo Assimétrico, Ob. cit., p. 145

${ }^{212}$ Idem, p. 159.

213 Cf. Constitución y Autonomías, in Federaismo y Cuestión Federal en España, Manuel Chust (ed.), Castelló de la Plana, Publicacions de la Universitat Jaume I, 2004, p. 289. 
diálogo e na cooperação intergovernamental quanto da adoção de assimétricas competencias, voltadas a compatibilizar as heterogeneidades de ordem cultural, histórica e étnica - mostra-se original e parece ancorado em um sistema racional e eficiente. Observase ainda que esses dois recursos têm, conjuntamente, conseguido fomentar o surgimento da noção de lealdade dos atores periféricos em relação ao todo, e tal elemento é imprescindível para a manutenção e o aperfeiçoamento de qualquer Estado composto, seja uma Federação ou um Estado regional. Assim, do cotejo entre os contextos espanhol e brasileiro, destaca-se que, ante a inexistência de fortes tensões históricas, culturais ou étnicas no Brasil, transparece que, aqui, seria dispensável introduzir assimetrias estruturais que concedessem competências particularizadas aos entes, pois as mazelas econômicas potencializadas pela diversidade dos parceiros federados são contornadas, com maior precisão, mediante adequadas técnicas de cooperação entre governos.

\section{II.3.3. O Estado Federal Alemão: A Cooperação como Técnica de Superar Acentuadas Disparidades Econômicas}

A aprecição dos aspectos implementados na Alemanha para amenizar os terríveis efeitos da desigualdade territorial atesta o grande interesse que aquela Federação nutre pela temática. Nos termos assinalados por JOÃo PAULO BACHUR, a questão da equalização regional é ponto preponderante na contemporânea ordenação constitucional, financeira e tributária alemã, uma vez que, em razão de fatores históricos - os quais foram reforçados pela reunificação ocorrida formalmente em 1990 -, naquele Estado sedimentou-se a orientação de que as políticas sociais devem ser pensadas de modo estrutural. De tal sorte, a ordem de reduzir as desigualdades regionais assume a feição de um projeto de desenvolvimento e de distribuição de riquezas que não pode prescindir de ajustes no pacto federativo que, de fato, compensem as problemáticas disparidades ${ }^{214}$.

A preocupação com o tratamento das heterogeneidades que surgem da multiplicidade de atores federativos não impede que alguns autores, como ROLAND STURM, afirmem que a Alemanha comporta um modelo de Federação juridicamente simétrica, se analisada sob o ponto de vista estrutural. Ocorre que as partes autônomas, à exceção da regra para a composição do Conselho Federal (Bundesrat), encontram na Constituição previsões que lhes garantem tratamento igualitário diante de outros parceiros federados,

${ }^{214}$ Cf. Federalismo Fiscal, Atribuições Fiscais Constitucionais e Equalização Regional: EUA, Alemanha e Brasil em Perspectiva Comparada, in Revista do Serviço Público, vol. 56, n 4, out/dez 2005, p. 378. 
devendo as mesmas promoverem uniformidade das condições de vida para toda a população. Não obstante sejam visíveis muitas diferenças econômicas, históricas e geográficas entre os atores políticos que integram o Estado alemão, não há expressa autorização no texto constitucional que permita o estabelecimento de assimetrias competenciais que os coloquem em situações diversificadas ${ }^{215}$.

As vedações à reformulação da isonomia federativa disposta às unidades políticas germânicas não impedem, no entanto, que, no funcionamento das relações federativas lá institucionalizadas, as assimetrias de direito classificadas como do tipo relacional sejam colocadas em prática com expressiva frequência. Em verdade, as transferências de recursos operacionalizadas pelo poder central não descuidam de atender o elevado propósito colocado pela política nacional de igualar, dentro das possibilidades, as condições econômicas de todos os entes, sobretudo daqueles que, no passado, compactuavam dos valores do sistema comunista, porque ligados à parte oriental do Estado cindido com o término da Segunda Guerra Mundial ${ }^{216}$. Essa prática vem sendo, cada vez mais, estimulada como meio adequado de abortar pretensões, propagadas por alguns entes federados, de monopolizar as atenções do poder central, em função dos favoráveis indicadores econômicos e sociais que demonstram ${ }^{217}$.

$\mathrm{Na}$ atualidade, colocados de modo sucinto os fatores que esclarecem quais as formas encontradas pela Federação alemã para cumprir a tarefa de compensar as desigualdades econômicas de suas partes, afere-se que esse Estado também se vale de tratamentos diferenciados que se concretizam no âmbito das relações intergovernamentais, a exemplo do Canadá e do Estado Autonômico da Espanha. Essa constatação reforça o entendimento defendido de que os desníveis de ordem financeira (os quais, por consequência, impedem o desenvolvimento de determinadas regiões dos Estados compostos) são melhor corrigidos com as técnicas relacionais de assimetria, haja vista a

215 Cf. The Constitution under Pressure: Emerging Asymmetrical Federalism in Germany?, in in Accommodating Diversity: Asymmetry in Federal States, Robert Agranoff (ed.), Ob. cit., p. 137.Grife-se que, acerca da fixação do número de membros do Bundesrat, KONRAD HESSE averba que esse órgão é composto de membros dos governos estaduais, que são por estes designados, abrindo-se a possibilidade de, em virtude da população de cada ente, esse número ser aumentado. De tal sorte, explica HESSE que "cada Estado tem, pelo menos, três votos; estados com mais de 2 milhões de habitantes tem quatro, estados com mais de 6 milhões de habitantes têm cinco, estados com mais de 7 milhões de habitantes têm seis votos (artigo 52, alínea 2)", Elmentos de Direito Constitucional da República Federal da Alemanha, Ob. cit., pp. 456-457.

${ }^{216}$ Cf. Idem, ibidem.

${ }^{217}$ Cf. Klaus-Jürgen Nagel, El Federalismo Alemán. ¿ Más Cooperación o Nueva Asimetría?, in Revista de Estudios Políticos, $\mathrm{n}^{\circ}$ 118, oct./dic. 2002, p. 66. Igual posicionamento é capitaneado por SIMON BULMER, Efficiency, Democracy and Post-unification Federalism in Germany: A Critical Analysis, in in Recasting German Federalism: The Legacies of Unification, Charlie Jeffery (ed.), London, Pinter, 1999, pp. 325-326; e ARTHUR BENZ, From Unitary to Asymmetric Federalism in Germany: Taking Stock After 50 Years, in Publius, vol. 29, n 4, Fall 1999, pp. 76-78. 
relevância que, em tais cenários, a cooperação intergovernamental assume para a governabilidade.

O escopo deste trabalho é veicular o entendimento de que, no caso brasileiro, onde o Estado federal sofre drásticos efeitos provocados, em parte, pela ausência de coesão entre as elites regionais - o que dificulta a construção de um consistente sentimento de lealdade federativa -, e também por força de abruptos desníveis socioeconômicos entre suas regiões, formados durante anos de desgastes políticos no Estado nacional. Indica-se, portanto, que o mais adequado é utilizar as relações entre governos para compatibilizar as disparidades. Assim, da mesma forma que os países tomados como parâmetro de comparação nesta parte do trabalho evidenciam os efeitos benéficos que podem ser aportados nos Estados compostos pela coerente e planejada cooperação entre governos, é recomendada à Federação brasileira repensar suas práticas de disciplinar a atuação conjunta entre o governo nacional e os periféricos, ou entre estes considerados especificamente, visando o desenvolvimento de eficientes peças de acomodação das diferenças.

Ainda que hajam inúmeras particulariedades entre os países analisados, um ponto em comum pode ser identificado: a pertinência e o relativo sucesso dos acordos intergovernamentais para viabilizar a superação dos desgates político-institucionais que têm sua gênese nas heterogeneidades de suas partes. E isso, por si só, figura como um encorajador estímulo para que o nosso país, também atingido por sérios comprometimentos socioeconômicos, também busque, por meio da arquitetura de um coerente sistema de cooperação entre seus entes, desenvolver fórmulas adequadas para superar o inquietante quadro de desigualdades regionais. 


\title{
III. A MATERIALIZAÇÃO DA ASSIMETRIA NO ESTADO FEDERAL: OS PRINCIPAIS INSTRUMENTOS DE CONCRETIZAÇÃO DOS ARRANJOS JURÍDICO-INSTITUCIONAIS DIFERENCIADORES
}

\begin{abstract}
"A federação, quando autêntica, exige o tratamento igual de todos os componentes, o que na prática pode ser um mal, criando uma solidariedade forçada e meramente formal. Isto porque a igualdade jurídica, se imposta onde não há igualdade de fato, é o começo da injustiça".
\end{abstract}

DALMO DE ABREU DALLARI ${ }^{218}$

\section{III.1. A Igualdade como Resultado: uma Proposta para o Equilíbrio Federativo}

O problema da delimitação da extensão e dos sentidos a ser atribuídos à igualdade dos entes autonômicos ganha notável destaque ao se centrarem as atenções nas implicações político-constitucionais ocasionadas pela aplicação da teoria do federalismo assimétrico. Ao mesmo tempo, esse ponto coloca-se como um desafio incomum ao engenho daqueles que se ocupam de modelar um vigoroso e operativo pacto para as Federações, especialmente aquelas construídas em ambientes onde a heterogeneidade territorial representa grandeza complicadora da elaboração de regimes estatais. A igualdade das unidades federadas é, sem dúvida, questão sempre levantada em estudos voltadas a analisar a coerência e a eficiência dos laços associativos que sustentam os Estados compostos da contempoaneidade.

Cabe esclarecer, inicialmente, que os efeitos irradiados pelo princípio da igualdade serão apreciados apenas em relação às unidades periféricas congregadas na Federação. Nesse ponto, é leva-se em conta a orientação apresentada por ALESSANDRA SILVEIRA, que pondera ser a União responsável pela coordenação da vida política do Estado federal e, em razão disso, mesmo não gozando de posição hierarquicamente superior àquela ocupada pelos Estados-membros, o poder central, em determiandas circunstâncias, acaba fixando os rumos de atuação de todos os entes períféricos, como ocorre com a elaboração das normas gerais no exercício de competências legislativas concorrentes (art. 24, § $1^{\circ}$, da Constituição Federal $^{219}$ ). É no exercício de funções como essa que se precisa admitir a desigualdade das

${ }^{218}$ Elementos de Teoria Geral do Estado, $28^{\mathrm{a}}$ ed., São Paulo, Saraiva, 2009, p. 262.

219 “Art. 24. [...] 
partes federadas, pois, do contrário, estar-se-á fomentando injustiças e impedindo-se o máximo desempenho das ações governamentais conjuntas que vierem a ser intentadas ${ }^{220}$.

Convém proclamar, aqui, que a igualdade dos entes, traduzidas em aspectos jurídico-constitucionais, sob nenhum ponto de vista, jamais poderá conduzir ao combate da diversidade regional, uma vez que os valores desse princípio são evocados para o cultivo da tolerância e da flexibilização das fórmulas de estruturação do Estado federal. A ordem de instituir a igualdade material em face das unidades federadas converte-se, portanto, em fator de incentivo ao desenvolvimento de mecanismos de engenharia constitucional que permitam a convivência harmoniosa das diferenças que, inexoravelmente, estarão presentes nos Estados compostos.

Com o federalismo assimétrico, o que se propõe, em síntese, é fazer com que a noção aristotélica de igualdade, consubstanciada nos parâmetros da justiça distributiva, seja alçada à condição de vetor que oriente a disposição das peças que integram o Estado federal. Por tal motivo, a assimetria contraria o entendimento de que a igualdade dos entes federados seja compreendida como uma situação de isonomia, já que a coesão do pacto federativo requer muito mais do que a declaração de igualdade frente à lei ${ }^{221}$. Nesse sentido, assevera MARIA GARCIA que as renovadas compactuações que a estrutura estatal vem sofrendo ao longo do tempo decorrem da insuficiência da construção teórica segundo a qual o Estado federal se baseia na absoluta igualdade de seus entes e na liberdade destes em contratar uma união duradoura ${ }^{222}$.

A igualdade das unidades político-administrativas da Federação, ao ser interpretada sob os influxos da assimetria, permite que o pacto federativo instítua cuidados jurídicos diferenciados aos entes federados que demonstrarem particularidades prejudiciais ao exercício da autonomia ordinariamente concedida aos congêneres. Assim é que se afirma que o aspecto mais festejado da Federação assimétrica está justamente no emprego de disciplinas diversificadas a circunstâncias específicas, o que requer a utilização adequada e controlada de mecanismos de compatibilização das desigualdades desestabilizadoras do regime de descentralização instituído. $\mathrm{O}$ fundamental para o sucesso dos regimes

$\S 1^{\circ}$ - No âmbito da legislação concorrente, a competência da União limitar-se-á a estabelecer normas gerais".

220 Cf. Alessandra Silveira, Cooperação e Compromisso Constitucional nos Estados Compostos, Coimbra, Almedina, 2007, p. 348.

${ }^{221}$ Cf. Enrico Carloni, Lo Stato Differenziato: Contributo allo Studio dei Principi di Uniformità e Differenziazione, Torino, G. Giappichelli, 2004, pp. 28-29.

${ }^{222}$ Cf. O Modelo Político Brasileiro: Pacto Federativo ou Estado Unitário, in Lições de Direito Constitucional em Homenagem ao Jurista Celso Bastos, André Ramos Tavares, Gilmar Ferreira Mendes e Ives Gandra da Silva Martins (coord.), São Paulo, Saraiva, 2005, p. 781. 
assimétricos é que a referida diferenciação ocorra na estreita medida das heterogeneidades apuradas, sob pena de subverter as ideias primaciais que informam a justiça distributiva.

Feitas essas considerações, a percepção a que se chega é a de que a assimetria federativa prega, em essência, a utilização analógica dos parâmetros de conformação do princípio da igualdade entre os indivíduos, transmutando-os para o campo da ordenação dos territórios regidos por processos de federalização. Nessa esteira, faz-se referência a MARIA GlÓRIA E. P. D. GARCIA, que sentencia ser a principiologia afeita à igualdade material "uma ânsia maior de justiça, uma exigência de igualdade reportada à própria lei e não já meramente às situações a que ela se aplica: uma igualdade que se apresenta não como ponto de partida, mas como resultado, como algo que se espera alcançar" ${ }^{\text {"22 }}$. De fato, caberá ao postulado da igualdade figurar como norte obrigatório e permanente dos Estados assimétricos, já que é a perseguição incessante desse objetivo que fomentará a elaboração dos importantes arranjos institucionais voltados a acomodar a diversidade.

Tal raciocínio, certamente, é o primeiro elemento que caracteriza as assimetrias de direito que podem surgir em Estados federais. A aplicação dessa formulação teórica tende a fazer com que se abandone a prática reiterada de remeter idêntico tratamento às unidades federativas, porque seriam elas, em tese, iguais perante as regras que cimentam o pacto que as mantém unidas. A diferenciação jurídico-constitucional dos entes da Federação tem como escopo permitir que todos eles, independentemente das características adversas que ostentem, tenham condições reais de exercício do autogoverno, num quadro de verdadeira igualdade substancial diante dos demais atores autônomos situados no mesmo nível governamental.

Em que pesem as múltiplas consequências que a transposição da axiologia da igualdade material para o contexto do federalismo pode trazer, não se pode defender que, em Estados federais assimétricos, os entes federados seriam autênticos titulares do direito fundamental à igualdade, pois o ponto em discussão não está no emprego de tal princípio para limitar ou impelir a ação do Estado. A dissimetria busca orientar as relações estabelecidas entre as peças que se entrelaçam no jogo federativo da descentralização política, criando a possibilidade de que as unidades periféricas não sejam castigadas pelas características factuais que naturalmente guardam.

${ }^{223}$ Estudos sobre o Princípio da Igualdade, Coimbra, Almedina, 2005, p.63. Acerca da apresentação das diretrizes que regem a aplicação concreta do princípio da igualdade, consultar, na literatura pátria, CELSO Antonio Bandeira de Mello, Conteúdo Jurídico do Princípio da Igualdade, $3^{\mathrm{a}}$ ed., São Paulo, Malheiros, 2009, pp. 37-43. 
Ao enfrentar a problemática de estender a posição de sujeito de direitos fundamentais a pessoas jurídicas, JORGE MIRANDA reconhece a impropriedade de propagar a ideia de que os entes federados poderiam evocar, nos exatos moldes feitos pelas pessoas jurídicas de direito privado, a fundamentalidade consignada no direito de igualdade para obrigar o poder central a direcionar tratamento diferenciado às partes federadas ${ }^{224}$. Consoante estatui, "se os direitos fundamentais são situações jurídicas ativas das pessoas enquanto membros da comunidade política, seria contraditório pensar em direitos fundamentais das entidades em que se desdobra o poder político ou configurar nesses moldes relações estritamente políticas ou administrativas. Os direitos de participação das regiões e das autarquias locais na dinâmica estadual reconduzem-se a fenômenos de descentralização e equilíbrio do poder" 225 .

A precisão de tais considerações assenta a convicção de que, nos Estados compostos assimétricos, a função atribuída ao princípio da igualdade é outra bem diferente daquela evocada pelas pessoas jurídicas privadas diante de ações estatais. Em verdade, o tratamento federativo diferenciado está atrelado a assuntos de índole governamental, explicitando que a igualdade levantada pela configuração assimétrica do Estado federal pauta-se em preocupações pragmáticas, em especial no compromisso de garantir atenção plena às necessidades humanas. Caso exista algum direito fundamental à igualdade a ser tutelado pela assimetria, por certo, é o direito ao tratamento igualitário de todos os indivíduos de um mesmo Estado, por mais complexas e dificultosas que sejam as bases naturais, culturais e econômicas dessa organização estatal.

Nessa direção, ALESSANDRA SILVEIRA expõe que, em regimes estatais que assumem formas assimétricas, o central geralmente deve determinar padrões mínimos de direitos fundamentais a ser observados por todas as unidades federadas, pois, dessa forma, estar-se-á resguardando a igualdade no exercício de direitos pelos indivíduos situados em

${ }^{224}$ Cf. Manual de Direito Constitucional, Tomo IV, $3^{\text {a }}$ ed., Coimbra, Coimbra Editora, 2000, pp. 81-82.

225 Idem, ibidem. No mesmo sentido: Cf. Ángel J. GómeZ Montoro, La Titularidad de Derechos Fundamentales por Personas Jurídicas: un Intento de Fundamentación, in Revista Española de Derecho Constitucional, ano 22, $\mathrm{n}^{\circ}$ 65, may./agos. 2002, p. 105; e Cf. FrANCISCO DE BORJA LÓPEZ-JURADO EsCRIB ANo, La Doctrina del Tribunal Constitucional Federal Alemán sobre los Derechos Fundamentales de las Personas Juridico-Publicas: su Influencia sobre nuestra Jurisprudencia Constitucional, in Revista de Administración Pública, $\mathrm{n}^{\circ}$ 125, may./agos. 1991, pp. 557-558. Ainda sobre esse tema, PEDRo CRUZ VILLALON mitiga a orientação que nega os direitos fundamentais às pessoas jurídicas de direito público, pois admite que "o direito à efetiva tutela jurisdicional encontra-se reconhecido a todas as pessoas jurídicas, tanto privadas como públicas, incluído o próprio Estado. Não há previsão, no entanto, que poderes públicos venham a ser titulares de outros direitos fundamentais, com apenas algumas exceções muito específicas, como é o caso da liberdade de expressão para os meios de comunicação social ligados ao Estado ou o direito fundamental à autonomia universitária para as Universidades, públicas e privadas", Dos cuestiones de Titularidad de Derechos: Los Extranjeros; Las Personas Jurídicas, in Revista Española de Derecho Constitucional, ano 12, ${ }^{\circ} 35$, may./agos. 1992, p. 83. 
entes diversos ${ }^{226}$. A Federação que se valhe dos recursos da dissimetria jurídica evidencia, em última análise, convergência de esforços para proporcionar a efetivação dos direitos fundamentais, ainda que os fatores de ordem fática dificultem o cumprimento de tal meta.

O emprego da assimetria representa, dessa forma, compromisso em alcançar o reequilíbrio da conjuntura política que sempre estará, por razões naturais, desequilibrada $^{227}$. Nas Federações assimétricas, a concepção de igualdade material faz com que o federalismo seja agente promotor de valores vinculados à justiça distributiva e à proporcionalidade. Como reflexo direto dessa mentalidade, o critério inflexível do tratamento uniforme direcionado às unidades federadas precisa ser abandonado, porque a prática de padronizar o diferente é acusada de ser o principal elemento perpetuador das disparidades que comprometem a coesão dos laços associativos ${ }^{228}$. De fato, se houver níveis expressivos de insatisfação do povo com a forma de Estado adotada é muito provável que as estruturas governamentais não durem, exceto se forem introduzidos habilidosas ferramentas que consigam contornar os pontos de tensão formados.

Ademais, não é exagerado afirmar que em países onde as disparidades interpessoais são destacadas, como consequência direta, as heterogeneidades inter e intra-regionais também serão sentidas nas várias frentes de organização do Estado. Obviamente, quanto maior o grau de diferenças regionais constatado, muito mais difícil será a articulação de formas de coordenação federativa e a implementação de direitos sociais de grande envergadura, sobretudo aqueles que demandam atuação conjunta das unidades federadas, será dificultada, quando não inviabilizada ${ }^{229}$. Daí é que se percebe que resistências políticas em aceitar a assimetria federativas, em geral, escondem intenções políticas que estão muito longe em preservar os interesses da população.

A propósito, Peter Pernthaler enfatiza o aspecto que estimula os discursos assimétricos é o fato de a doutrina constitucional destinar considerável atenção às relações jurídicas encabeçadas pelos entes políticos dos Estados compostos. Os estudos realizados permitem que, ao menos no plano teórico, analise-se a igualdade jurídica das partes que

\footnotetext{
${ }^{226}$ Cf. Ob. cit., p. 352.

${ }^{227}$ A justificativa para atribuir tratamento assimétrico a determinados entes federados está na verificação de que eles, em virtude de variáveis naturais, não são iguais entre si. Esse dado, intuitivamente, surge de forma automática no arcabouço institucional organizado que funciona como base do Estado federal. DIRCÊO TORRECILLAS RAMOS confirma esse entendimento, ao observar que "todo e qualquer Estado possui em sua organização alguma assimetria de fato, o que provoca correções de fato e de direito. Mesmo aqueles formados por agregação, como os Estados Unidos, em que as unidades componentes já eram organizadas e parecia estranha a preocupação com a assimetria, também, adotaram ajustes para corrigir diferenças", $O$ Federalismo Assimétrico, Ob. cit., p. 60.

${ }^{228}$ Cf. Esther Seijas Villadangos, Ob. cit., p. 439.

${ }^{229}$ Cf. Rui de Brito Álvares AfFOnSO, A Federação na Encruzilhada, Ob. cit., p. 32.
} 
formam o concerto federativo sob duas perspectivas: a visão denominada de igualdade "numérica" ou "aritmética" e a percepção chamada de igualdade "geométrica",230. Mais do que uma questão de mera terminologia, ver-se-á abaixo que a adoção de uma ou de outra modalidade de instrumentalizar o postulado da igualdade das unidades autônomas implicará consequências bastante diversas para os regimes federativos criados.

A igualdade "numérica" ou "aritmética" alinha-se à noção de isonomia, o que leva o regime instituído a não se preocupar com as dimensões apresentadas pelos entes. Nessas Federações, concede-se idêntico status a todas as unidades federadas que se enquadrem num mesmo nível governamental, independentemente das particularidades consignadas no interior de cada uma delas. A segunda acepção, por seu turno, exprime um conceito claramente aproximado do sentido de igualdade material, porquanto estabelece, dentro do possível, paridade entre os entes. Aqui, os pontos de tensão, em regra, serão contornados por instrumentos jurídicos e políticos que objetivem compensar os desníveis advindos de inúmeros fatores estruturais, tais como a dimensão territorial, o poder econômico, a articulação política, entre outros aferidos diretamente em cada uma das unidades autônomas $^{231}$.

As explicações prestadas possibilitam deduzir com segurança que nas Federações que se valem do expediente da igualdade "aritmética" certamente não haverá (ou existirão poucas) assimetrias “juris”. Os Estados federais que tratam isonomicamente suas partes terão os contrastes regionais e as disparidades que dimanam do meio social compreendidos como elementos naturalmente amalgamados ao federalismo, de modo que, para os entes federados que sofrem com as disparidades formadas, não há nada a se fazer, exceto aceitar passivamente as consequências decorrentes do regime instituído, ainda que a diversidade mostre-se negativa e desagregadora da unidade pretendida. Além disso, esse tratamento aplicado ao pacto federativo dificulta sobremaneira a construção de um projeto unificado de desenvolvimento, mesmo que tal intento venha a ser ensaiado de modo insistente.

Por outro lado, os Estados federais adeptos da fórmula da igualdade "geométrica", onde a igualdade material representa parâmetro obrigatório para elaboração e subsistência do pacto federativo, as disparidades regionais - ou assimetrias factuais - não demonstram ser um problema insolúvel e deflagrador de crises. Ao contrário, funcionam como nortes e limites para a criação e o contínuo aperfeiçoamento de ajustes jurídicos e institucionais voltados ao tratamento daquelas disparidades que, depois de estudo acurado, são

\footnotetext{
${ }^{230}$ Cf. Ob. cit., p. 20.

${ }^{231}$ Cf. Idem, ibidem.
} 
entendidas como prejudiciais à Federação. A diversidade, nesses países, acaba sendo encarada como um estímulo ao revigoramento dos laços associativos, visto que nenhuma unidade federativa será injustiçada em razão de aspectos factuais que lhes são próprios.

Do que foi até o momento exposto, já é possível concluir que o enfrentamento do complicado ponto acerca da interpretação a ser conferida ao princípio da igualdade federativa significa elemento de extrema relevância na arquitetura dos Estados federais. Essa certeza ajuda a explicar o motivo pelo qual, no Brasil, a Federação parece precisar de ininterruptos ajustamentos, pois aqui, não obstante a vasta e acentuada gama de contrastes regionais verificáveis, o regime federativo estabelecido pressupõe a absoluta isonomia dos entes federados. Essa impressão é categoricamente confirmada por MANOEL GONÇALVES FERREIRA FILHO, que atesta o fato de que "o exame do direito vigente demonstra que, no federalismo brasileiro, a preocupação com a igualdade entre os Estados-membros redunda numa rigorosa simetria quanto a competências e modelo organizacional"232.

Daí porque muitos dos recentes institutos desenvolvidos no universo da Federação exigem a reavaliação de alguns pontos da teoria geral do federalismo há muito reproduzidos pelo constitucionalismo. As recentes discussões formadas a respeito da adequada conformação dos sistemas federativos convergem em defender a desnecessidade de se ter, entre os entes periféricos, uma hermética igualação competencial. Também é bastante apregoada a superação do dogma de idêntica representação numérica dessas unidades nos órgãos do poder central ${ }^{233}$. Mostra-se acertada, portanto, a proposição de aplicar essas novas fórmulas no contexto que serve de sustentáculo à Federação brasileira, visto que a assimetria parece ser o caminho indicado para alcançar o desejado equilíbrio em Estados compostos que consagram grandes disparidades regionais, tal qual ocorre no Brasil.

\section{III.1.1. As Desigualdades Regionais e a Instauração de Preocupantes Quadros de Desarmonia Federativa}

O Estado brasileiro pode ser eleito como exemplo para a análise dos reflexos advindos da adoção de uma ou de outra vertente do postulado da igualdade federativa. Nesse particular, constata-se que, ao longo de sua trajetória histórica, a Federação no país esteve rigorosamente ancorada no princípio da igualdade formal dos Estados-membros, o

${ }^{232}$ Aspectos do Dirito Constitucional Contemporâneo, São Paulo, Saraiva, 2003, p. 183.

${ }^{233}$ Cf. Alessandra SilveIRA, Ob. cit., pp. 349-348. 
que determina, ainda nos dias atuais, alguma prevalência - embora mitigada - dessa orientação político-constitucional há muito sedimentada no constitucionalismo pátrio. Não obstante os esforços para quebrar essa prática, é impossível negar que muitos dos “desvios,

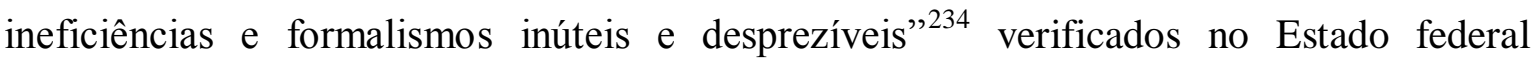
brasiliero decorrem diretamente do tratamento isonômico remetido a partes federadas tão radicalmente diferentes.

Em matéria de estruturação de Estado federal, costuma-se defender que todas as unidades periféricas são, no geral, consideradas formalmente iguais entre si, o que faz com que lhes sejam atribuídas mesmo grau de autonomia, além de idênticas competências legislativas e tributárias. Tal diretriz, não obstante encontre fundamentos no nascedouro do federalismo, pode também representar uma decisão política que afasta as benesses decorrentes da instituição de um regime de descentralização política que consagre efetivamente a unidade na diversidade ${ }^{235}$. Em verdade, as variadas mudanças estruturais que ocorreram nos últimos tempos no âmbito dos Estados compostos e democráticos atestam que a Federação não pode deixar de acompanhar as novas configurações exigidas para o eficiente funcionamento de todo o aparato estatal.

Visualiza-se, por conseguinte, o fato de que, em Estados federais com patente heterogeneidade territorial, a absoluta isonomia em relação aos seus integrantes pode contrariar não apenas o espírito do federalismo, mas ainda, consoante preconiza MANOEL GONÇALVES FERREIRA FILHO, ensejar o surgimento de "uma absurda e injusta identidade na diversidade ${ }^{\text {236. }}$. O regime federativo deixaria então de significar garantia de convivência pacífica e harmoniosa entre suas unidades para transformar-se em preocupante artifício de padronização das partes federadas. Neste caso, se as demandas e exigências regionais por cuidados específicos forem muito acentuadas e imprescindíveis para a

${ }^{234}$ Maria Garcia, O Modelo Político Brasileiro: Pacto Federativo ou Estado Unitário, in Lições de Direito Constitucional em Homenagem ao Jurista Celso Bastos, André Ramos Tavares, Gilmar Ferreira Mendes e Ives Gandra da Silva Martins (coord.), Ob. cit., p. 805.

${ }^{235}$ Cf. Registra MANOel GonÇAlves FerReira Filho que essa principiologia foi adotada pela Convenção de Filadélfia, em virtude da necessidade de se fazer com que as instituições federais de poder pudessem ser compreendidas pela totalidade de Estados federalizados, em especial por aqueles que estampavam condições de maior retardamento econômico, social e político em face às demais organizações políticas que também figuravam como partes do conjunto. A despeito de seu pertinente emprego no contexto estadunidense, onde a Federação deriva de uma agremiação de Estados independentes, o constituinte brasileiro de 1891, ignorando a natureza centrífuga do federalismo brasileiro, adotou-o aqui sem nenhuma adaptação, fator que contribuiu decisivamente para emperrar a possibilidade de superação das desigualdades regionais por meio do uso disciplinado e racional do autogoverno franqueado às unidades federadas, Cf. A Democracia Possível, Ob. cit., pp. 111-112.

${ }^{236}$ A Democracia Possível, Ob. cit., p. 112. 
manutenção do conjunto, certamente, o pacto idealizado não será mantido íntegro e o sistema sofrerá sérios problemas de funcionamento.

Os métodos conhecidos de diferenciação de competências constitucionais, bem como de estabelecimento de relações intergovernamentais específicas em função das peculiaridades demonstradas pelas unidades autônomas - mesmo que do mesmo patamar governamental -, evidenciam, via de regra, observância da advertência de que o federalismo deve reconhecer "não somente as diferenças naturais (tais como o tamanho, a população, a história etc.) existentes entre as unidades da Federação, mas também as diferenças formais de cunho jurídico entre essas unidades, seja em relação aos poderes jurisdicionais e as obrigações, seja no tocante à adoção das instituições determinadas pelo poder central, ou com a aplicação das leis e dos programas nacionais" 237 .

No cumprimento desse desiderato, é imprescindível que seja aferida a capacidade suportada pelo Estado federal para tolerar uma ou mais formas de autonomia, sem que a diferenciação transforme-se em privilégio inaceitável atribuído a determinados entes. Ainda sobre o delicado assunto da harmonização do princípio da igualdade com a distribuição de competências na Federação, é interessante referenciar que o sistema de uniformidade competencial tem sido indigitado como insatisfatório e prejudicial à coesão e à harmonia que precisam reinar entre as partes federadas, porque pode suscitar competições e rivalidades entre elas.

A propósito, ENRICO CARLONI anota que a igualação competencial prevista de modo inflexível pode constranger sujeitos diversos a moverem-se na mesma velocidade. $\mathrm{Na}$ prática, isso acaba resultando na impossibilidade de alguns dos entes periféricos cumprirem os encargos e as funções que lhes são destinadas pelo sistema federativo. Também poderá ocorrer a redução das potencialidades de autogoverno de unidades específicas, as quais deixarão de explorar segmentos de grande interesse para a região na qual se situa, uma vez que o pacto instituído pode não reconhecer a conveniência do exercício de algumas competências para os outros entes situados no mesmo plano governamental $^{238}$.

O referido autor firma ainda significativa conclusão, resumida nos seguintes termos: "o problema das realidades territoriais deve ser respondido por meio de caminhos diversos, num e noutro caso: seja renunciando-se ao exercício das competências que lhes

${ }^{237}$ David MiLne, Igualdad o Asimetría: ¿Por qué Elegir?, in Asimetría Federal y Estado Plurinacional: El Debate sobre la Acomodación de la Diversidad en Canadá, Bélgica y España, Enric Fossas e Ferran Requejo (eds.), Ob. cit., p. 69.

${ }^{238}$ Ob. cit., p. 66. 
são (estruturalmente) inadequadas, seja trilhando-se, sempre que o ordenamento consentir, percursos autonômicos diferenciados, por meio da assunção de competências e novos encargos, como ocorre com os serviços públicos locais" ${ }^{239}$. A partir das considerações destacadas, enxerga-se a inviabilidade de compelir distintas realidades geoeconômicas e políticas a receberem tratamento jurídico padronizado no quesito competência. Eventual rigorismo exacerbado do pacto federativo nesse ponto pode, em situações extremas, transmutar-se em poderoso fator de desagregação, no lugar de ser uma eficiente ferramenta de coesão e de manutenção dos laços associativos.

É preciso ainda ter como norte que a vontade política fundamental motivadora da decisão de institucionalizar o Estado Federal, além de ser uma opção consciente, tomada em prol da liberdade, traz também em seu bojo a manifesta intenção de se instaurar constitucionalmente a igualdade entre os entes subnacionais integrantes do conjunto federativo. De fato, esses são aspectos de irrefutável relevo na definição dos valores elementares que, em geral, determinam a criação de ordens federativas em todos os cantos do mundo ${ }^{240}$. Figura, portanto, como indefensável qualquer pretensão ensaiada no sentido de transformar o sistema federativo em instrumento de opressão e de asfixia do espírito de autonomia que caracteriza essa forma de Estado.

Longe de admitir-se a igualdade federativa como a simples tradução de uma promessa ou intenção do poder constituinte, deve ela representar a garantia de equalização das diferenças regionais. Não obstante essa nobre função, o mandamento de igualdade entre as unidades do Estado federal nunca é aplicado em sua inteireza, e esse dado inviabiliza a sedimentação de um vigoroso e ajustado pacto federativo, calcado em reiteradas e salutares relações intergovernamentais regidas pela solidariedade. Seja em virtude de descasos e de resistências políticas, seja por dificuldades de ordem técnica, a ausência de tratamento igualitário impede que se forje um verdadeiro sentimento de lealdade federativa, o que ocasiona, não raro, episódios de competitividade e de desapreço ao espírito associativo protagonizados pelos entes.

Parece evidente, assim, que o consciente e correto emprego do princípio da igualdade representa singular recurso disponibilizado para a eliminação dos padrões de comportamento governamental, entendidos por SÉRGIO ABRANCHES como disciplinados

\footnotetext{
239 Idem, ibidem.

${ }^{240}$ Em clara consonância com esse ponto de vista, reconhece o Senador JUTAHY MAGALHães que, "em retrospectiva histórica, é possível afirmar que as coletividades que procuraram se organizar sob a forma de federação tinham em mente os riscos para a liberdade e para o respeito às diversidades culturais e regionais que podem suscitar o caráter centralizado do caráter unitário", Diário do Congresso Nacional, Seção II, 04.03.1997, in Anais do Senado Federal, vol. 4, Brasília, Senado Federal, 1997, p. 1072.
} 
pela lógica da facção ${ }^{241}$. De acordo com essa lógica, as unidades federadas optam, em algumas circunstâncias, por tomar decisões políticas egoísticas e, com isso, adotam programas de governo que denotam clara intenção de fomentar interesses parciais e não cooperativos. Formam-se perigosos e predatórios pontos de tensão entre as partes do conjunto federativo, podendo ocorrer ainda erosão das bases de sustentação do Estado federal e o esfacelamento dos elos federativos.

Embora tais preocupações possam denotar radicalismo exagerado, principalmente quando se leva em conta a história constitucional do Brasil, na qual a forma federativa é mantida desde a Constituição da República de 1891, podemos encontrar em nossa experiência federativa exemplos elucidativos de comportamentos dessa índole que provocaram graves abalos ao Estado nacional. É certo que, entre nós, nunca houve nenhum movimento insurrecional marcantemente motivado por aspirações secessionistas, entretanto, demonstra ser equivocado defender que o país sempre esteve imune (e, inclusive, que atualmente continua livre) contra atitudes sectárias e desestruturantes do conjunto federativo. Nesse diapasão, cabe registrar o angustiante período vivenciado após o advento da atual ordem constitucional, no qual tomou forma a chamada "guerra fiscal" 242 , combatida com grande empenho pela Corte Constitucional do país ${ }^{243}$.

Sobre os aspectos ligados ao desencadeamento da "guerra fiscal", FERNANDO LUIZ ABRUCIO apresenta o complexo panorama que determinou esse fato no país. Num grosso resumo, verifica-se que a desigualdade estampada às realidades estaduais esteve no âmago desse acontecimento, uma vez que os planos nacionais de desestatização, realizados a partir dos anos 90, fizeram com que os Estados mais ricos da Federação perdessem muitos de seus atrativos econômicos e infraestruturais. Tal dado aumentou consideravelmente a disputa entre os governos estaduais, na medida em que muitos dos Estados, antes incapazes de apresentar condições mínimas de competitividade, começaram a formular interessantes

\footnotetext{
${ }^{241}$ Cf. Presidencialismo de Coalização: O Dilema Institucional Brasileiro, in Dados, vol. 31, $\mathrm{n}^{\circ} 1$, Rio de Janeiro, 1988, pp. 29-30.

${ }^{242}$ GUILHERME BUENO DE CAMARGO define "guerra fiscal” como "a generalização de uma competição entre entes subnacionais pela alocação de investimentos privados por meio da concessão de benefícios e renúncia fiscal, conflito este que se dá em decorrência de estratégias não cooperativas dos entes da Federação e pela ausência de coordenação e composição dos interesses por parte do governo central", A Guerra Fiscal e seus Efeitos: Autonomia x Centralização, in Federalismo Fiscal, José Maurício Conti (org.), pp. 203-204.

${ }^{243}$ Paradigmáticos julgados do Supremo Tribunal Federal atestam o compromisso dessa Corte em colocar termo à guerra fiscal, como por exemplo, a Medida Cautelar na Ação Direta de Inconstitucionalidade $\mathrm{n}^{\circ}$ 2.377-MG, julgada pelo Plenário do STF em 22/02/2001, relatada pelo Ministro SEPÚlvEDA PERTENCE, e com publicação no DJ em 07/11/2003, texto extraído de documento digital disponível no sítio eletrônico: www.stf.jus.br, acesso em 30/12/2009.
} 
propostas para a captação do investimento privado $^{244}$. A ausência de uma mentalidade fundada no solidarismo fez com que Estado federal fosse o maior impactado por essas práticas de hostilidades financeiras e tributárias recíprocas, uma vez que o pacto federativo apresentou índices preocupantes de desarmonia entre suas peças.

Outros fatores também podem ser elencados como agentes deflagradores da "guerra fiscal" no Brasil, são eles: a ausência de uma política nacional e de políticas regionais de desenvolvimento; a aquisição de maior mobilidade física por parte das empresas; a consolidação pelos entes estaduais da ampla autonomia tributária adquirida com a promulgação da nova Constituição; a recessão no governo Collor que acelerou a luta selvagem por investimentos que garantissem alguma recuperação de receita, bem como a criação de empregos que compensassem os postos de trabalho eliminados pela recessão e também pela abertura comercial do país ${ }^{245}$. Foi nesse ambiente de profundas mudanças estruturais que as partes federadas, de modo individualizado e sem se aliarem para elaboração de programas conjuntos de gastos e de atração de investimentos (alternativa cooperativa), iniciaram um processo de implantação de várias medidas estratégicas para conquistar novas empresas e alocá-las em seus respectivos parques industriais.

O gravoso comportamento não-cooperativo iniciado pelos atores da Federação contaminou, em maior ou menor medida, toda a gama de relacionamentos intergovernamentais empreendidos, de modo a fazer com que essa imprescindível ferramenta de equalização das disparidades regionais deixasse de ser operada em toda sua potencialidade. Ademais, conforme observa RICARDO VARSANO, no caso brasileiro, os incentivos e as renúncias fiscais acabaram, na prática, fazendo com que as grandes empresas privadas direcionassem seus investimentos para os lugares onde havia melhor infraestrutura e recursos humanos mais preparados, o que significou a vitória, no embate fiscal, dos Estados mais desenvolvidos e $\operatorname{ricos}^{246}$. Em outras palavras, a "guerra fiscal" agravou ainda mais a crônica desigualdade entre as regiões do país, promovendo, por conseguinte, o recrudescimento do quadro de injustiças sociais com o qual o Estado federal precisa conviver e, principalmente, servir como instrumento de correção.

Do que foi apresentado até este ponto, é possível concluir que a igualdade federativa há de ser compreendida como proposta de projeção de esquemas de

${ }^{244}$ Cf. Os Barões da Federação: os Governadores e a Redemocratização Brasileira, $2^{\mathrm{a}}$ ed., São Paulo, Hucitec, 2002, pp. 193-194.

${ }^{245}$ Cf. Fernando Luiz Abrucio, Os Barões da Federação: os Governadores e a Redemocratização Brasileira, Ob. cit., pp. 193-194.

${ }^{246}$ Cf. A Guerra Fiscal do ICMS: Quem Ganha e Quem Perde, in Planejamento e Políticas Públicas, $\mathrm{n}^{\circ} 15$, jun. 1997, pp. 3-18., pp. 10-11. 
descentralização política pautados pelo compromisso com a unidade nacional, sem jamais perder de vista as instransponíveis diferenças sociológicas, culturais, éticas e econômicas locais vivenciadas pelas unidades periféricas. Os pactos federativos devem ser desenvolvidos para primarem pelo respeito integral das multiplicidades regionais e ainda tendo como estandarte a missão de permitir a efetiva compatibilização de contextos onde existam gritantes heterogeneidades territoriais. Vários recursos deverão ser manipulados para alcançar esse propósito, o que certamente exigirá tanto a reformulação de sistemas de repartição de competências que se apresentam como insensíveis à diversidade, quanto o aperfeiçoamento das relações intergovernamentais praticadas por todos os entes federados, o que abarca ainda, necessariamente, a cooperação estabelecida apenas entre as unidades subnacionais.

Não é infundado defender que todo sistema federativo que conseguir incorporar essa substanciosa noção de igualdade terá vencido importante etapa no processo histórico e político de afirmação do federalismo como insubstituível peça de respeito da diversidade territorial. Também conseguirá servir como referência a outras Federações que, em virtude de inúmeros e cambiantes aspectos factuais, precisam fazer da descentralização política a chave para a pacificação do meio social, haja vista que o Estado federal é, em essência, um engenho habilitado a fazer com que as disparidades deixem de ameaçar a unidade do conjunto $^{247}$. Sem dúvida, o caminho a ser percorrido inicia-se pela precisa identificação dos pontos de tensão e de fragilidade que impedem o pleno funcionamento do esquema federativo, pois, somente depois de vencida essa etapa, os arranjos assimétricos poderão ser idealizados com segurança para transformar as realidades onde serão aplicados.

\section{III.1.2. Transitoriedade e Excepcionalidade dos Arranjos Assimétricos}

Assinalados os motivos principais que recomendam a adoção de esquemas federativos assimétricos, passa-se ao estudo das características temporais dos arranjos diferenciadores que poderão ser implantados. Assim é que, numa perspectiva geral, visualiza-se, nas medidas afeitas aos comandos de assimetria constitucional patente transitoriedade, uma vez que o tratamento diferenciado atribuído a uma entidade autônoma específica (ou a um grupo delas) será modulado temporalmente pelas condições das disparidades apresentadas por essa mesma unidade federada. $\mathrm{Na}$ prática, o tempo de

247 Cf. Misabel Abreu MaChado Derzi, Nota de atualização à obra de Aliomar Baleeiro, Direito Tributário Brasileiro, 11ª ed., Rio de Janeiro, Forense, 2003, p. 124. 
duração do tratamento assimétrico elaborado deve ser precisamente delimitado pelo momento no qual se atingem índices razoáveis de equilíbrio entre todas as partes do conjunto estatal.

A par da característica da transitoriedade, outro importante sinal distintivo das assimetrias precisa ser evidenciado: a excepcionalidade. As assimetrias apenas devem ser cogitadas - e, consequentemente, colocadas em prática - quando impossível combater as forças desagregadoras da Federação por meio de outros recursos. Além disso, depois de amenizados os elementos responsáveis pela configuração da insustentável disparidade regional, tais técnicas jurídicas tendem a ser abandonadas. Confirma essa conclusão, o afirmado por ESTHER SEIJAS VILLADANGOS, atentando para o aspecto de que, "numa perspectiva geral, tais medidas de tutela que materializam esse conceito de justiça distributiva apresentam um caráter tendencialmente transitório, cuja duração vem delimitada pelo momento em que precisamente se alcance o equilíbrio ou a proporcionalidade entre as diferentes partes implicadas" 248 .

O dinamismo e a excepcionalidade estampados na assimetria constituem, pois, elementos garantidores da correta aplicação dessa técnica de organização estatal. Com efeito, não poderia ocorrer diferente, uma vez que, caso os arranjos assimétricos fossem pensados para existirem permanentemente, ter-se-ia na disciplina assimétrica não um louvável instrumento de equalização e de correção das distorções factuais, mas, ao contrário, seria ela odioso fator de multiplicação das desigualdades. Cessadas aquelas disparidades acentuadas que desestabilizavam o Estado federal, deverão os instrumentos de diferenciação federativa ser abandonados, ainda que persistam outros pontos (nãoproblemáticos) de desigualdade entre as unidades federativas.

Como se deduz, essa aludida transitoriedade estará, em regra, relacionada com a utilização de aparatos jurídico-institucionais responsáveis pela materialização da assimetria de direito ou "juris". Reconhece-se, por conseguinte, que o caráter temporário impregnado ao federalismo assimétrico decorre, consideravelmente, da impermanência dos ajustes institucionais instituídos para a equalização dos desníveis verificados no Estado. Somente enquanto houver pontos de tensão que compliquem o pleno funcionamento do pacto federativo, é indicado empregar tais mecanismos, uma vez que não se pode querer terminar com a diferença na Federação, sob pena de completo esvaziamento do espírito federativo.

${ }^{248}$ Ob. cit., pp. 439-440. 
Por isso é que, no que respeita às assimetrias de fato, entende-se que tais desigualdades certamente trarão o rótulo da continuidade, tendo em vista que elas derivam de um sem-número de grandezas conjunturais, todas aferíveis no interior de cada Estado federal considerado em particular. As assimetrias fáticas podem até sofrer alterações, entretanto, nunca deixarão de existir, uma vez que a formação das mesmas é consequência da ação de forças históricas, geográficas, culturais, econômicas, entre outras. Ademais, é perceptível ainda que muitos desses fatores estão presentes há séculos na história dos Estados compostos ou ainda são impossíveis de serem modificados pela ação de recursos jurídicos idealizados ${ }^{249}$.

Tem-se, portanto, como certo que é a partir de indicadores empiricamente coletados nos contextos federativos que os indicativos de conveniência política harmoniosa irão guiar a formulação dos mecanismos diferenciadores correspondentes à assimetria de direito, bem como fixar o período aventado para que esses mecanismos sejam utilizados. $\mathrm{O}$ ideal é obter um completo diagnóstico da Federação antes de redesenhá-la com base nas concepções teóricas imanentes à ideia de assimetria. Também se deve ter como horizonte que a diferenciação constitucional das competências e do status de alguns entes federados terá, inexoravelmente, de redundar no máximo de benefícios para todos os sujeitos autônomos envolvidos no pacto federativo.

O resultado esperado com o advento das técnicas de assimetria gira em torno da sensível redução de posições de prevalência que algumas unidades assumem em detrimento das demais. Os entes que se destacam no contexto da Federação acabam, tendenciosamente, defendendo com veemência seus interesses próprios, o que implica a trágica desconsideração das necessidades e das urgências dos demais integrantes do conjunto e do próprio Estado federal. A instauração desse quadro exige remendos, sobretudo porque, no geral, muitas das unidades que demonstram expressiva dimensão territorial, melhores índices econômicos ou avantajada influência política terminam valendo-se desses atributos para desencadear o acirramento das desigualdades regionais.

Conclui-se, portanto, que as assimetrias jurídicas objetivam estabelecer verdadeiro quadro de igualdade material entre as partes da Federação. A ideia é conseguir alcançar esse quadro por meio da criação de engenhos jurídicos e políticos que permitam a equiparação dos entes, mesmo que se tenha de diferenciá-los em pontos determinados, sempre na exata medida e na precisa proporção de suas desigualdades factuais. Não é

${ }^{249}$ Cf. ERIC J. HobSBAwm, Nações e Nacionalismo desde 1870, $3^{\text {a }}$ ed., Rio de Janeiro, Paz e Terra, 2002, pp. 29-30. 
demais anotar que os dados, as informações e os índices aptos a certificar a real situação dos agentes estatais envolvidos no processo de positivação dessas medidas deverão ser exaustivamente apreciados e ponderados antes da constitucionalização de qualquer experimento nesse sentido.

\section{III.2. Representação Política das Unidades Federadas e Disparidades Regionais}

O tema da representação das unidades federadas nos órgãos decisórios do poder central - em especial, no Senado Federal - merece apreciação pormenorizada frente aos vetores que direcionam o estudo e a compreensão do federalismo assimétrico. O realce que deve ser conferido à matéria é reconhecido de forma declarada por DALMO DE ABREU DALlARI, o qual enuncia que "o ponto crítico da organização federativa reside, precisamente, no governo federal, pois na prática é impossível assegurar-se a todas as unidades federadas uma participação exatamente igual no exercício do poder político"250. No geral, o que ocorre é a verificação de um preocupante quadro em que os entes autônomos que gozam de posições confortáveis em relação aos congêneres transformam as instâncias de formação da vontade do Estado federal num aparelho de defesa voraz de seus interesses particulares, independentemente de entrarem ou não em colisão com as aspirações de todo o conjunto federativo ${ }^{251}$.

Um aparte deve ser feito sobre os aspectos do federalismo a serem apreciados na sequência. Trata-se da questão referente à imprescindibilidade do Senado, como órgão representativo dos entes federados, na configuração do Estado federal. Como informado por FERnANDa Dias MENEZES de AlmEIDA, dentre os aspectos societários da Federação, há que existir instrumentos de participação dos Estados-membros no governo central, e tem sido usual atender essa orientação por meio da institucionalização de um Senado no

\footnotetext{
${ }^{250}$ Elementos de Teoria Geral do Estado, Ob. cit., p. 262. Em complemento, HoRST DiPPEL explica que, em relação à Europa, o bicameralismo, na prática, dispõe-se como um instrumento assimétrico, uma vez que as "segundas Câmaras da Áustria, Bélgica, Alemanha, Irlanda, Espanha e Reino Unido podem classificar-se como equivalentes em poder às Câmaras Baixas, mesmo tendo em conta que os três primeiros Estados são Estados federais e que a Espanha e o Reino Unido podem considerar-se como Estados em transição para um futuro ainda nã determinado", História do Constitucionalismo Moderno: Novas Perspectivas, Lisboa, Fundação Calouste Gulbenkian, 2007, pp. 114-115.

${ }^{251}$ Vale registrar que JOHN JAY, ao apresentar, em "O Federalista", as linhas retoras de organização do Senado Federal, não cogitou a possibilidade de que cenários marcados por patentes diferenças regionais pudessem influenciar o peso político da representação desenvolvida pelos entes federados. Isso é comprovado pelo seguinte excerto: "Uma vez que todos os Estados estão igualmente representados no Senado por homens de elevada capacidade e desejosos de promover os interesses de seus constituintes, haverá um grau uniforme de influência nesse órgão, especialmente enquanto forem escolhidas com cuidado as pessoas adequadas e houver regularidade no respectivo comparecimento", ALEXANDER HAMILTON, JAMES MADISON e JOHN JAY, O Federalista, Ob. cit., p. 497.
} 
âmbito do Legislativo federal ${ }^{252}$. Não obstante existir Federações, a exemplo de Camarões, que não adotam o bicameralismo, em atenção aos postulados do regime federativo, deverão existir outros mecanismos para permitir que as partes federadas influenciem a tomada de decisões por parte da União ${ }^{253}$.

Essa recomendação não pode ser esquecida, pois o Estado composto está obrigado a respeitar não apenas os indivíduos, mas também seus respectivos grupos regionais. "Aos níveis de poder mais próximos do controle e da participação popular, deve-se reconhecer a representação e salvaguarda dos legítimos interesses; para que, ademais, as leis genéricas possam ser realmente concernentes à vontade consensual de toda a Nação, mas nunca a vontade de determinada parte específica da mesma, ainda que numericamente majoritária” ${ }^{, 254}$. Com o fito de atender as linhas norteadoras difundidas nesse ponto, não raro, os encarregados de criar as estruturas políticas e institucionais da Federação deparamse com extremadas dificuldades na elaoração de uma fórmula que consiga estabelecer idêntica representatividade a entes demasiadamente desiguais ${ }^{255}$.

Sobre esse complexo assunto, é oportuno fazer referência às conclusões tiradas por ROBERT R. BOWIE e CARL J. FRIEDRICH, em estudo comparatístico baseado nas características do Estado federal construído na Austrália, Canadá, Alemanha, Suíça e Estados Unidos, estabelecendo interessantes dados no tocante ao entendimento das técnicas de distribuição real de cadeiras e de votos na Câmara Alta. Segundo o apurado, a composição desse importante órgão do concerto federativo é muito mais influenciada pelas condições factuais e por fatores de ordem prática arraigados a cada Federação do que pelos discursos teóricos fundamentados pelos estudiosos do federalismo. Assim, numa primeira visão, percebem os autores que, "naqueles casos em que a disparidade entre os entes federados não é excessiva, existe a tendência de se conceder a igualdade de votos. $\mathrm{O}$ contrário se dá nos países em que a disparidade é extremada, de modo que a fixação de

\footnotetext{
${ }^{252}$ Cf. Competências na Constituição de 1988, Ob. cit., pp. 13-14.

${ }^{253}$ Cf. Idem, p. 14.

254 Augusto Zimmermann, Ob. cit., pp. 119-120.

255 JOSÉ AFONSO DA SILVA grifa que a atual configuração do Senado brasileiro não atende à importante incumbência de representar os Estados-membros da Federação, entretanto, não aponta a notória dificuldade de obter-se uma fórmula que consiga estabelecer paridade entre os atores federados como causa dessa constatação. Segundo, preceitua o problema está no fato de que, na atualidade, os partidos um mandato representativo partidário o que, não raro, coloca os senadores de um Estado em oposição aos interesses do governante estadual. Daí, conclama uma séria reflexão sobre os benefícios que uma eventual reforma nas atribuições constitucionais destinadas a essa Casa Legislativa traria para o Estado nacional, Cf. Comentário Contextual à Constituição, $3^{\mathrm{a}}$ ed., São Paulo, Saraiva, 2007, p. 388.
} 
cadeiras leva em conta essas diferenças, favorecendo-se sempre as unidades menores com mais votos proporcionais à população delas" 256 .

Diante da mencionada orientação firmada por BOWIE e FRIEDRICH, adquire relevância apreciar propostas de adoção de critérios heterodoxos para definir o número de membros que integrarão o Senado Federal em Estados tomados por acentuada diversidade territorial. É defendida por alguns, como ALESSANDRA SILVEIRA, a viabilidade de combinar critérios populacionais ou multiculturais para chegar-se à obtenção de números seguros de senadores em função dos entes federados, o que, por via reflexa, levaria ao abandono da regra inflexível de número fixo de cadeiras por Estados ${ }^{257}$. Propostas dessa natureza representam evidente consagração de assimetrias jurídicas no âmbito do federalismo e que trazem, como objetivo precípuo, a intenção de amenizar os efeitos negativos derivados isonomia das partes formadoras da vontade federativa nos órgãos encarregados de atuar como centros de decisão política da Federação.

Tais formas de compatibilização e de equalização dos instrumentos de representação dos entes periféricos nos Estados federais estarão, em regra, imbuídas de promoverem duplo propósito. O primeiro ponto consiste em evitar a intervenção do poder central nas entidades periféricas sem que haja motivo constitucionalmente previsto para tanto, já que competirá a esse órgão político controlar, ainda que parcialmente, os drásticos e excepcionais atos de mitigação da autonomia estadual tomados para resguardar o interesse geral da Federação, tal qual ocorre com a hipótese de decretação da intervenção federal. O outro aspecto a ser observado está em evitar que as unidades federativas de menor contingente populacional percam suas vozes nos órgãos representativos do Estado federal em virtude da utilização, pelos entes mais populosos e de grande expressão política, de suas maiorias na outra casa do Legislativo bicameral: a Câmara Baixa ${ }^{258}$.

De modo geral, a preocupação em contornar os entraves que surgem da idêntica representação federativa indica a tomada de consciência de que "o método de formação de vontade por meio da averiguação majoritária simples é razoável e suportável, se for possível pressupor uma homogeneidade substancial de todo o povo"259, consoante sentencia CARL SCHMITT. A aplicação de raciocínio analógico, por meio do qual esse axioma é aplicado ao universo do Estado federal, chama a atenção para a necessidade de repensar-se o sistema de escolha dos representantes das unidades autônomas junto ao poder

${ }^{256}$ Estudios sobre Federalismo, Buenos Aires, Bibliográfica Argentina, 1958, p. 55.

${ }^{257}$ Cf. Ob. cit., p. 378.

${ }^{258}$ Cf. Robert R. BowIE e CARL J. FrIEDRICH, Estudios sobre Federalismo, Ob. cit., p. 54.

${ }^{259}$ Legalidade e Legitimidade, Belo Horizonte, Del Rey, 2007, p. 28. 
central operacionalizado por muitas Federações, em especial aquelas tomadas por consideráveis desníveis territoriais.

No que tange a essa complicada matéria, ANTONIO TRUYOL Y SERRA acredita que a determinação dos assentos na Casa Parlamentar encarregada de servir de canal para a defesa dos interesses das unidades federadas deve estar fundamentada na técnica da ponderação. Conforme defende, esse método seria o mais apropriado para estabelecer equilíbrio entre as variadas partes do conjunto nacional, abandonando-se o injusto critério de igualdade absoluta. A adoção desse método exige a avaliação conjugada de variados critérios e o cômputo de múltiplos fatores de relevância política para a configuração do regime federativo, avaliando-se, além do elemento populacional embutido nos entes periféricos, outras variantes importantes para a composição das respectivas unidades políticas como, por exemplo, o potencial econômico; a participação financeira nos gastos comuns da Federação; o montante produzido pelos respectivos entes na integralização do Produto Interno Bruto (PIB) $)^{260}$.

Não obstante a estranheza que essa proposta pode causar aos padrões brasileiros de definição dos assentos legislativos do Senado Federal, essa técnica não exprime uma modalidade inovadora de designação de cadeiras no Parlamento. Em verdade, consoante ensina o próprio TRUYOL Y SERRA, a ponderação lastreada em outras grandezas que não somente os números populacionais das entidades políticas é uma variante da representação proporcional, especificamente da denominada proporcionalidade relativa ou realista, utilizada sempre que se pretende preservar a representatividade dos corpos políticos diminutos, corrigindo-se, concomitantemente, as consequências advindas do igualitarismo consagrado formalmente entre as unidades da Federação ${ }^{261}$.

Vale registrar ainda que o emprego de tal espécie de representação geralmente acontece em Estados dotados de destacados níveis de tolerância e de integração. Confirma essa constatação memorável trabalho confeccionado por FRANCISCO FERNÁNDEZ SEGADO, sobre o bicameralismo com foco na análise da natureza e das funções atribuídas pelo constitucionalismo ao Senado. A partir de consistente pesquisa ancorada em Direito Comparado, retrata o autor que, dentre as duas principais modalidades de representação dos Estados-membros da Federação no Senado, uma demonstra estar filiada à chamada representação ponderada. Trata-se daquela categorizada como sendo a fórmula que vigora

${ }^{260}$ Cf. La Representación Ponderada y su Aplicación en Federalismo Germano, in Revista de Política Internacional, $\mathrm{n}^{\circ}$ 162, 1979, p. 14.

${ }^{261}$ Idem, pp. 15-16. 
em países onde a Câmara Alta adota a desigualdade representativa das entidades federadas, em virtude da necessidade de adequar à representação das unidades territoriais aos parâmetros da proporcionalidade e/ou do desenvolvimento ${ }^{262}$.

Esclarece também que o método aludido é aplicado por países como a Alemanha, tendo em vista que os Länder possuem três, quatro, cinco ou seis membros no Bundesrat ou Senado, em atenção a sua respectiva população; a Áustria, que possui um sistema em que o número de membros no Bundesrat oscila entre três e doze; o Canadá, cuja composição do Senado obedece a uma lógica bastante particular: os cento e quatro membros da Câmara Alta estão divididos muito desigualmente entre as províncias, de forma que o número de assentos varia desde os vinte e quatro senadores de Ontário e Quebec até os seis de Terranova e apenas um senador para o território de Yukón e outro para os territórios do Noroeste; e também a Índia, a qual, por seu turno, emprega uma fórmula parecida com aquela praticada pelo Canadá para obter representação diferenciada entre seus Estados e territórios na Rajya Sabha ou Câmara dos Estados ${ }^{263}$.

A importância da correta e da justa representação dos entes autônomos perante os órgãos da União mostra-se inquestionável, pois, do contrário, estar-se-ia diante de um vínculo de subordinação, e não de coordenação entre o poder central e as unidades periféricas. A equilibrada participação das instâncias subnacionais na formulação das ações governamentais de caráter nacional levou JUAN FERRANDO BADIA a afirmar não existir "autêntico federalismo - mesmo quando a amplitude dos vínculos federativos varie - se as unidades federadas não participam, com seus representantes, da formação dos órgãos federais e da elaboração de suas decisões" ${ }^{\text {264 }}$. Evidentemente, será impossível instituir um regime federativo que estampe justiça e respeito à diversidade se as disparidades regionais não estiverem devidamente acomodadas em arranjos jurídicos no interior das instâncias federais, tal qual o é o Legislativo da União.

\section{III.2.1. Os Impactos na Autonomia Política Decorrentes dos Desníveis Regionais}

A questão separatista sempre é lembrada nas discussões que abordam o dimensionamento da representação das partes federadas junto aos órgãos formadores da

\footnotetext{
${ }^{262}$ Cf. El Bicameralismo y la Naturaleza del Senado, in Revista Española de Derecho Constitucional, Ano 2, $\mathrm{n}^{\circ} 6,1982$, p. 66.

${ }^{263}$ Cf. Francisco Fernández Segado, El Bicameralismo y la Naturaleza del Senado, in Revista Española de Derecho Constitucional, ano 2, nº 6, 1982, pp. 66-67.

${ }^{264}$ El Federalismo, in Revista de Estudios Políticos, no 206-207, 1976, p. 32.
} 
vontade do poder central. Isso acontece porque "o princípio da participação apresenta tripla finalidade: a) preservar a identidade, a autoridade e a autonomia dos membros federados; b) garantir a eficiência da integração, buscando medidas que equilibrem unidade e diversidade; e c) preservar o vínculo federativo" ${ }^{265}$. Assim, preconiza-se que representa condição sine qua non para o sucesso e a permanência de todo Estado federal projetado a criação de uma Casa Legislativa habilitada a representar efetivamente os entes federados, independentemente da posição que ostentem ante seus similares e, inclusive, diante do próprio poder central.

Por óbvio, quanto maiores os desníveis regionais, mais cuidados e compromissos são esperados do constituinte no que respeita à eleição de critérios para a fixação do número de assentos legislativos em função das unidades federadas, pois o ideal é projetar um sistema representativo em que os mais diferentes entes tenham idênticas condições de influenciar os rumos tomados pela Federação. Espera-se, portanto, que ocorra a criação de instituições parlamentares federativas por meio das quais os entes autonômicos possam todos levar a fórum seus problemas, anseios e dificuldades, enfim, lutar efetivamente pela superação de seus impasses regionais, ainda que essas desigualdades sejam desinteressantes às demais unidades político-administrativas da Federação.

Essa Câmara de entes federados tem ainda de ser um órgão onde existam possibilidades reais de cada unidade federada conseguir, por meio do uso da parcela do poder decisório que venha a obter, influenciar decisivamente nos rumos da vida nacional, mesmo que, para tanto, precise ser esquematizado um sistema que observe as respectivas proporções de importância das partes para o conjunto ${ }^{266}$. Ainda que pareça estranho aos cânones clássicos do federalismo, a intenção primeira do movimento em prol da assimetria, no tocante aos critérios de fixação do número de membros do Senado ou da Casa que o equivalha, justifica-se no fato de que, enquanto apenas parte dos integrantes da Federação estiver participando ativamente da formação da vontade política do Estado, será impossível assistir à formação de um autêntico sentimento de solidariedade, hábil a atar todas as partes do Estado federal num sistema cuja engrenagem evidencie busca incessante pelos interesses do todo.

\footnotetext{
${ }^{265}$ CRistiano Franco Martins, Ob. cit., p. 88.

${ }^{266}$ Em sentido contrário, SAMPAIO DÓRIA aponta que "o senado representa a vontade dos estados federados, sem levar em conta o território, a população, a cultura ou a riqueza de cada um deles. Sem essa igualdade de representação política das unidades federativas, a federação típica, com suas linhas puras, a verdadeira federação não existe", Direito Constitucional, vol 1º, tomo II, 4ª ed., São Paulo, Max Limonad, 1958, p. 474.
} 
Preocupado com as condições políticas e sociais que levam à consagração, no Pacto Fundamental, da ideia de federalismo assimétrico, WILL KYMLICKA adota o pressuposto de que nem sempre haverá uma revolução constitucional para a consagração da assimetria no plano da Constituição ${ }^{267}$. Defende que a melhor maneira de implantação de instrumentos assimétricos seria aquela na qual ocorreria o contínuo balanceamento de parcela de poderes já atribuídos para as unidades por meio do emprego de emendas à Constituição, deliberadas e votadas por essa Câmara de Estados. Por isso é que a representação adequadamente estabelecida dos entes junto ao Legislativo precisa traduzir, em sua composição, uma verdadeira situação de equilíbrio de forças entre todos os entes federados.

Convém registrar que a asserção esposada, especificamente no tocante à conveniência de empregar instrumentos de reforma constitucional para adoção da assimetria federativa, encontra respaldo, em grande parte, no entendimento lançado por Diogo FigueIREDo Moreira Neto de que "a primeira condição de permanência de uma Constituição está na própria possibilidade de se renovar sem ruptura”268. Soa incontrastável, portanto, a certeza de que a busca histórica pela estabilidade constitucional depende em muito da capacidade apresentada pelo Texto Maior de adaptar-se às contingências e evoluções do meio social e do poder político. Também não poderia ser diferente, pois há de concordar-se que, "se há incompatibilidade e choque entre o texto constitucional e a realidade política, econômica, social e cultural, pode-se estar certo: a mudança acabará sendo do texto, não da realidade"269.

Essa parece ser a orientação aceita por BRUCE ACKERMAN em matéria de ajustamento dos pontos centrais da estrutura estatal, haja vista o autor observar que uma das grandes utilidades da leitura da obra "O Federalista", de ALEXANDER HAMILTON, JAMES MADISON e JOHN JAY, está em conhecer o aconselhamento feito pelos pais da Federação de que as revoluções constitucionais drásticas precisam ceder lugar para a participação do povo no funcionamento das instituições do Estado, de modo a permitir que se retirem os melhores resultados possíveis dos mecanismos já existentes na realidade

267 Cf. Federalism, Nationalism and Multiculturalism, in Theories of Federalism: A Reader, Dimitrios Karmis e Wayne Normann (eds.), Ob. cit., p. 283

268 Diogo Figueiredo Moreira Neto, A Revisão Constitucional Brasileira: Como se Situa, qual seu Alcance e quais seus Limites, Rio de Janeiro, Lumen Juris, 1993, p. 8.

${ }^{269}$ Cf. Idem, ibidem. 
constitucional, abandonando-se a crença de que o futuro da política constitucional passaria necessariamente por um reordenamento das bases fundantes do Estado ${ }^{270}$.

Essas reflexões, quando transpostas para a prática, anunciam o quão difícil pode ser a implantação concreta do federalismo assimétrico, porque as mudanças em favor da assimetria, geralmente, serão realizadas pelo emprego dos instrumentos reformadores da Constituição, votados por representantes de todos os entes federados em Câmaras Altas. Acontece que a maioria dos Senados atualmente existentes sofrem, em maior ou menor intensidade, com os efeitos negativos da ação de alguns poucos entes que conseguem sobrepor seus interesses regionais em face aos demais atores federativos. Isso acontece porque, na maioria das vezes, a composição dessas Casas Parlamentares prima pelo respeito à igualdade formal das partes que a integram, e, tal ficção é implacavelmente desmitificada pela realidade, porque uma série de variantes fáticas acaba conferindo posições de destaque a determinadas peças do conjunto.

Em termos diversos, a isonomia dos entes da Federação pode trazer como consequência a possibilidade de membros específicos do concerto federativo obterem posições de destaque na condução dos rumos do Estado. Quando isso se manifestar, essas unidades tendem a capitanear posições refratárias à vontade de ajustamento do quadro constitucional, o que inviabiliza a realização de um satisfatório balanceamento dos fatores de poder, dificultando em demasia a superação dos problemas ligados à desigualdade regional. Os membros que gozam das referidas posições confortáveis, sem dúvida, brigarão ao máximo para não perderem as condições que já possuem.

Por não compreender que a finalidade primordial da assimetria está em cimentar a coesão do pacto federativo que garante o adequado funcionamento do Estado federal, a maioria dos entes federados dificilmente será favorável às reformas constitucionais desencadeadas para reconhecer status diferenciado a outras unidades periféricas que são carecedoras do predicado assimétrico. O quórum exigido pela ordem constitucional para a aprovação de emendas que viabilizariam o sucesso desse desiderato chega a ser tão alto e difícil de ser obtido que qualquer proposta de inclusão de mecanismos assimétricos no texto da Lei Maior, ainda que amplamente apoiada, poderá vir a ser rechaçada no momento da votação ${ }^{271}$.

${ }^{270}$ Cf. Nós, o Povo Soberano: Fundamentos do Direito Constitucional, Belo Horizonte, Del Rey, 2006, pp. 237-238.

${ }^{271}$ Cf. Will KymLicka, Federalism, Nationalism and Multiculturalism, in Theories of Federalism, Dimitrios Karmis e Wayne Normann (eds.), Ob. cit., p. 283. 
Convém citar, a título elucidativo, ROBERT A. DAHL, que, ao considerar a realidade estadunidense, consegue comprovar a conclusão acima exposta. Assinala que a Constituição daquele país requer que a proposta de emenda constitucional seja aprovada por dois terços dos votos computados no Senado, o que, a contrário senso, permite afirmar que todo ato de reforma da Constituição poderá ser bloqueado pelo voto de dois senadores de um terço dos Estados, mais um voto adicional. Desse modo, como na referida Casa Legislativa cada um dos cinquenta Estados terão dois senadores, os quoruns anunciados, quando traduzidos em números absolutos, revelam que bastam trinta e quatro votos para abortar o processo de criação de emendas. E não é só. Além disso, caso o projeto de emenda seja aprovado no Senado Federal, ele precisará ser submetido ao referendo de três quartos das Assembleias Legislativas estaduais, podendo ser afastado por decisão contrária de um quarto mais um dos parlamentos estaduais, o que equivale a treze Estados discordantes $^{272}$.

Com o Brasil, tal qual o esclarecido por MARCELlo SiMÃo BRANCO, constata-se que a situação não é de menor complexidade quando o assunto em análise retrata as eventuais barreiras federativas que terão de ser vencidas para a aprovação de emendas à Lei Maior. Depois de pesquisar o papel desempenhado pelas forças políticas regionais atuantes no âmbito das duas Casas do Legislativo nacional, no campo do processo de votação e de aprovação das emendas constitucionais, explica o autor que, "se de um lado, os estados menos desenvolvidos podem aprovar a mudança constitucional no Senado, não podem fazê-lo por si mesmos na Câmara. O poder real destas três regiões [Centro-Oeste, Norte e Nordeste] é para vetar o interesse das outras duas regiões em mudar a Constituição, em ambas as casas" 273 .

Complementa o estudioso que, "por outro lado, se as regiões Sudeste e Sul não podem por si mesmas mudar a Constituição, podem vetar uma alteração que contrarie seus interesses em ao menos uma das casas, a Câmara dos Deputados. Dessa maneira, o princípio segundo o qual a proporcionalidade da câmara baixa compensa ou equilibra a

\footnotetext{
${ }^{272}$ How Democratic is the American Constitution?, $2^{\mathrm{a}}$ ed., Yale University Press, 2003, p. 161. Em abono, é interessante consignar a impressão de Francis HAMON, Michel Troper e Georges Burdeau no que respeita à disposição do Senado dos Estados Unidos, haja vista que tais autores, ao registrarem outra distorção verificada naquela Casa Parlamentar, acabam demonstrando a importância de instrumentos de assimetria nesse órgão federativo. Assim consideram: "O Senado representa os Estados numa base igualitária. Cada Estado elege então dois senadores. Disso resulta uma grande desigualdade na representação, já que existem Estados menos povoados - às vezes mais conservadores - com peso igual ao dos Estados mais povoados", Direito Constitucional, Barueri, Manole, 2005, p. 251.

${ }_{273}$ A Democracia Federativa Brasileira e o Papel do Senado no Ajuste Fiscal dos anos 90, Tese de Doutorado, Faculdade de Filosofia, Letras e Ciências Humanas da USP, São Paulo, 2007, p. 59.
} 
representação paritária da câmara alta, mantém-se na democracia federativa brasileira, mesmo com os índices de sobre-representação existentes na Câmara dos Deputados. Pois, se as regiões Norte, Nordeste e Centro-Oeste têm em conjutno o poder de aprovar e vetar no Senado, as regiões Sudeste e Sul podem vetar na Câmara dos Deputados. Há mais poder para as regiões Norte, Nordeste e Centro-Oeste, mas não de maneira suficiente para mudarem por si mesmas o status quo a seu favor. Já as outras duas regiões, se não podem manifestar um poder proativo, podem fazê-lo do ponto de vista reativo"274.

É pertinente concluir ainda que, no caso brasileiro, o efetivo equacionamento entre as unidades federadas em matéria de representação política junto às Casas do Legislativo federal, tomando como foco o aspecto populacional aderido a cada um desses entes, não tem sua relevância limitada ao processo de formação da vontade nacional na ocasião do exercício do poder de reforma constitucional. Sua relevância transcende esse ponto, pois o sucesso de políticas públicas lançadas pela União, e dependentes de maciça articulação de todas as instâncias governamentais do país, está diretamente relacionado com a possibilidade de as partes explicitarem ao poder central suas reais necessidades que precisarão ser atendidas pela ação conjunta dos atores da Federação.

Desse modo, seja ativa ou reativamente, o engajamento e os esforços de todos os núcleos político-administrativos que compõem o Estado federal terão grande repercussão no planejamento das ações estatais. Por tal motivo, é enfatizada a imprescindibilidade de definir idêntica importância à atuação parlamentar das unidades federativas, consideradas cada qual em específico e, se for o caso, compensadas as desigualdades que podem fazer com que elas tenham interesses tão divergentes. Reforça essa percepção o entendimento, cada vez mais forte, de que "parece que o futuro do federalismo será mais positivo quanto maior for o grau de participação popular na formulação das políticas públicas e na definição das prioridades a serem atendidas pela administração. O federalismo será então mais eficaz à medida que melhor prover os recursos financeiros necessários para que todos os entes possam definir quais as suas prioridades dentro do orçamento que lhes foi destinado" 275 .

\footnotetext{
${ }^{274}$ Marcello Simão Branco, Ob. cit., pp. 59-60.

275 Nelson De Freitas PORFírio JúnIOR, Federalismo, Tipos de Estado e Conceito de Estado Federal, in Federalismo Fiscal, José Maurício Conti (org.), Ob. cit., p. 12. Interessa ainda anotar a conclusão de FLÁVIO DA CUNHA REZENDE sobre a importância da interação intergovernamental para o êxito das políticas públicas que pretendem instituir reformas no Estado. Considera REZENDE que "conseguir cooperação para a mudança institucional aparece como o ponto nevrálgico da implementação das políticas públicas de reformas administrativas. Quanto mais a reforma propõe alterar os mecanismos de controle numa dada ordem institucional, menores são as chances de implementar a reforma. $\mathrm{O}$ modo específico pelo qual os diversos atores envolvidos na reforma percebem a relação entre controle e performance cria os incentivos à
} 
É interessante sublinhar a elucidativa exposição de DIRCÊO TORRECILLAS RAMOS, na qual se consigna que "a importância da representação e o seu equilíbrio avultam porque é o maior canal para influenciar os políticos, e, se a representação é maior ou menor, igual ou variável, é outra medida de simetria ou assimetria"276. Há de se ter em mente que a representação, o peso e a influência de cada Estado são variáveis na órbita do Estado Federal, e, em razão desse fato, podem existir arranjos voltados a reconhecer a pertinência de instituições especiais idealizadas para garantir integração da atividade estatal, mormente em territórios que apresentam flagrantes desníveis regionais.

Fica realçado o caráter assimétrico que pode ser assumido pelo sistema de representação federativa nos Estados que assumam o compromisso de fazer com que as aspirações de todas as unidades periféricas tenham um mínimo de relevância na tomada de decisões políticas pelo poder central. A técnica em foco é particularmente importante nos países que, a despeito de apresentarem problemáticas diversidades internas, nunca experimentaram outro método senão o de fixação de número idêntico de assentos na Câmara Alta para cada um dos entes federados ${ }^{277}$.

Como sempre existirão inúmeras variações nas características apresentadas pelas unidades da Federação (população, pujança econômica, tradição política, entre outros fatores), inevitavelmente, o poder e a influência exercida pelos entes junto à União nunca serão simétricos. Sabe-se ser comum a predominância, no âmbito do Legislativo nacional, os interesses defendidos pelos entes autônomos dotados de maior representatividade política e, na formulação de políticas públicas pelo poder central, dos entes dotados de maior representatividade ou poderio econômico. O atendimento das necessidades externadas pelas unidades menores fica relegado a segundo plano, haja vista que tais unidades raramente conseguem lograr êxito na execução das conhecidas práticas de barganha política.

Independentemente do ângulo em que se observe, há de se ter em mente que a percepção dos complexos fatores e forças que interferem na definição do pacto federativo não deve servir de desestímulo para o constante aperfeiçoamento do Estado federal. Não é sem motivo que proclama MiCHAEL BURGESS que "a inteligência da Federação está em sua infinita capacidade de acomodar e reconciliar a competição e, em algumas situações, o

cooperação ou à resistência à reforma, sendo um mecanismo crucial para explicar a falha [das políticas públicas executadas pelo poder público]", Por Que Falham as Reformas Administrativas?, Rio de Janeiro, Editora FGV, 2004, p. 17.

${ }^{276}$ O Federalismo Assimétrico, Ob. cit., p. 76.

277 Ronald L. Watts, The Theoretical and Pratical Implications of Asymmetrical Federalism, in Accommodating Diversity: Asymmetry in Federal States, Robert Agranoff (ed.), Ob. cit., pp. 33-34. 
conflito surgido da diversidade politicamente relevante dentro do próprio Estado. Tolerância, respeito, compromisso, barganha e reconhecimentos mútuos são suas palavraschave, e 'união' combinada com 'autonomia' é sua marca autêntica"278.

Observe-se ainda que essa peça fundamental do Estado federal chamada autonomia, conforme registra ENRIQUE ÁlVAREZ CONDE, “não tem de significar uma homogeneização das competências. E mais, se a autonomia tem sua razão de ser na diversidade territorial existente, a heterogeneidade se converte em uma consequência obrigatória do federalismo" ${ }^{279}$. Nenhum esquema federativo elaborado com atenção nos valores nucleares de descentralização política pode negar tratamento às diversidades regionais, pois do contrário restará completamente desfigurada a ideia de Federação. Por tal motivo, sobressai a importância de acreditar nos laços associativos - e nas consequentes relações político-governamentais deles decorrentes - como mecanismos insubstituíveis para a realização de ajustes compensadores da diversidade.

Nessa esteira, conclui ENRICO CARLONI ser a autonomia a principal criadora das diferenças que tomam formas jurídicas no federalismo, pois "a diversidade constitui produto natural do efetivo exercício da autonomia" 280 . É evidente que as heterogeneidades referidas pelo autor não são as assimetrias de fato, surgidas do contexto no qual a Federação se estabelece, mas sim as assimetrias relacionais, derivadas do constante firmamento de relações intergovernamentais entre os entes federados. Assim é que, quanto mais intensas as atividades de auto-organização, autogoverno, autoadministração e autolegislação desempenhadas pelas unidades federadas consideradas em suas singularidades, maiores serão as diferenças políticas verificadas entre elas.

É recomendado, por derradeiro, que aqueles Estados que tragam, em seu interior, significativas disparidades regionais recorram à assimetria federativa a fim de possibilitar ao projeto constitucional idealizado condições de viabilidade na criação de instituições, competências e tributos compatíveis ao estágio de desenvolvimento e às peculiaridades encabeçadas pelas diferentes unidades. Somente assim o pacto federativo não correrá o risco de se tornar, em vez de uma promessa de progresso e de união permanente, a razão

\footnotetext{
${ }^{278}$ Federalism and Federation: A Reappraisal, in Comparative Federalism and Federation: Competing Traditions and Future Directions, Michael Burgess e Alain-G. Gagnon (eds.), Toronto; Buffalo, University of Toronto Press, 1993, p. 7.

${ }^{279}$ Asimetría y Cohesión en el Estado Autonomico, in Asimetría y Cohesión en el Estado Autonómico: Jornadas sobre el Estado Autonómico: Integración y Eficacia, INAP (Instituto Nacional de Administración Pública), Ob. cit., p. 82.

${ }^{280}$ Ob. cit., p. 34.
} 
determinante do agravamento das desigualdades entre as partes e um incontrolável fator de violação do autêntico sentido de autonomia política.

\section{III.3. O Equilíbrio Regional e a Ininterrupta Necessidade de Adequação do Sistema de Repartição de Competências}

A compreensão da racionalidade e dos postulados teóricos que marcam a assimetria federativa requer acurada análise das bases doutrinárias que permitiram a definição desse significativo conceito para o universo dos Estados compostos. É preciso, de início, perquirir as circunstâncias históricas, os valores e os interesses teleológicos que permitiram a sedimentação e o gradativo emprego, nos cenários constitucionais da contemporaneidade, dessa vertente de organização político-constitucional da Federação. A deflagração do federalismo assimétrico, como já enunciado, foi dada pelos reclamos de se prestar respostas razoáveis e funcionais aos problemas advindos da diversidade e dos desníveis existentes no seio de tais Estados.

A cognição da importância a ser dispensada ao aspecto pluralista, incrustado inseparavelmente no âmago do Estado federal, confirma a grande envergadura atribuída progressivamente ao tema em questão. Essa relevância, por seu turno, está intimamente relacionada com o compromisso assumido por muitas Federações de somente reduzir as heterogeneidades que se mostrem desestabilizadoras e inconvenientes ao pacto federativo, preservando-se, na íntegra, as demais diferenças naturalmente formadas. Certamente, o federalismo assimétrico não objetiva a homogeneização de todas as unidades subnacionais, pois isso importaria na dramática eliminação de peculiaridades das regiões ou de grupos de população dentro do país, mormente quando se rememora que esse fator constitui um dos pressupostos lógicos para a evocação do sistema federativo como recurso de ordenação do $\operatorname{poder}^{281}$.

Cumpre ressaltar, por oportuno, que não são todas as disparidades que devem ser tratadas por meio da utilização das ferramentas e de engenhos criados a partir da tradução, no plano da prática, da teoria da assimetria. A salutar e necessária conservação da pluralidade que se manifesta na disposição dos caracteres inerentes às partes periféricas

\footnotetext{
${ }^{281}$ Nesse sentido, ROSAH RUSSOMANO grifa que a "presença do princípio federativo no Estado hodierno encontra suas raízes profundas nas diversidades que caracterizam a existência dos indivíduos e dos grupos sociais, bem como em seus anseios de unidade" (O Princípio do Federalismo na Constituição Brasileira, Editora Freitas Bastos, Rio de Janeiro, 1965, p. 13). Também observa José Alfredo DE OliveIRA BARACHO que "o federalismo, entretanto, não pode ser coerente em uma sociedade cujas diversidades são tão grandes que não podem levar à integração", Teoria Geral do Federalismo, Ob. cit., p. 8.
} 
deve fundir-se, consentaneamente, com a unidade sistêmica, coesa e racional, justificadora da existência do poder central. Esse poder, por seu turno, encarrega-se de atuar em escala nacional, imbuído do objetivo de garantir a consecução de níveis mínimos de integração e da harmonização exigidos para a permanência e o desenvolvimento do conjunto federativo, mesmo quando presentes múltiplas forças que provoquem a tensão entre as partes do todo.

Como consabido, essa compatibilização dos desníveis que permeiam as unidades federadas requer que as diferenças de origem, de costumes, por serem aspectos da cultura total, em princípio, sejam preservadas. Pondera JOSAPHAT MARINHO que "as desigualdades sujeitas à redução correspondem aos desequilíbrios oriundos de forças da natureza, como as calamidades, ou criados ou nutridos por erros políticos e administrativos. Esses desníveis precisam ser corrigidos, porque prejudiciais ao desenvolvimento nacional integrado e, portanto, a parcelas extensas da população" ${ }^{282}$. Daí a razão que justifica a necessidade de profunda investigação acerca dos pontos específicos de conformação estrutural que causam a desestabilização da unidade do Estado federal.

O mapeamento dos modos com que as desigualdades influem no âmbito do sistema constitucional de repartição de competências, bem como de divisão de rendas entre os entes federados, assume posição de relevo na operacionalização dos aparatos técnicos advindos da assimetria. A propósito, assevera FRANCISCO CAAMAÑO que "a desigualdade política, cultural, sociológica ou econômica, acaba se traduzindo em aspectos jurídicos e, sobretudo, em formas diversificadas de repartição do poder, de sorte que é possível diferenciar entre uma assimetria de solidariedade e uma assimetria de desigualdade (ou seja, uma desigualdade que compromete a igualdade)" ${ }^{, 283}$. Por isso é que se insiste tanto no ponto de que a homogeneização competencial pode ser fomentadora das heterogeneidades que comprometem o sistema federativo.

Os arranjos federativos não podem trazer a mera declaração de igualdade formal entre as unidades do Estado federal, em virtude da constatação óbvia: jamais existirá a plena igualdade sociocultural e econômica entre as partes federalizadas - são elas amplamente diferentes, uma vez que terão particularidades e índices estruturais dissonantes umas das outras. A efetiva calibração desses desníveis factuais, por meio da elaboração de um consistente e racional sistema de repartição de competências, bem como o estabelecimento de um regime de descentralização que apresente patamares adequados de divisão de riquezas, parece ser peça essencial para a obtenção do equilíbrio federativo.

${ }^{282}$ Cf. Direito, Sociedade \& Estado, Salvador, Memorial das Letras, 1998, p. 87.

${ }^{283}$ Ob. cit., p. 361. 
Além disso, jamais poderão ser atribuídos aos entes da Federação encargos e poderes fora das possibilidades reais de exercício apresentadas pelas respectivas unidades.

As consequências da negligência em cumprir tais recomendações podem levar ao completo fracasso do Estado federal projetado no texto constitucional. Ainda que seja intuitiva a prática de se conceder às unidades autônomas as mesmas instituições, tributos e competências, as Federações construídas em bases onde impera a diversidade regional dificilmente alcançarão unidade federativa se não empregarem ferramentas assimétricas. A invariável e hermética igualação competencial, institucional e financeira, ao ser aplicada em territórios que congreguem regiões acentuadamente díspares, certamente transmutar-seá em perigoso e implacável elemento potencializador do desmantelamento do espírito federativo de harmonização da diversidade.

Com efeito, Manoel GonçAlves FerReira Filho ilustra esse dilema, ao ponderar que tal prática pode levar "ao absurdo de, se o paradigma for as regiões atrasadas, dar às [partes] evoluídas instituições, competências e tributos aquém de sua capacidade; se for as avançadas, presentear com instituições, competências e tributos, regiões que não poderão com elas beneficiar-se"284. O que se espera de todo sistema de repartição de competência é que ele consiga realizar a efetiva e adequada acomodação dos múltiplos interesses regionais (os quais, às vezes, são declaradamente conflitantes). Ainda é válido sublinhar que, na elaboração do sistema de distribuição competencial, o ideal é a observância do consenso, de forma que todas as partes federadas possam externar seus posicionamentos e levar ao centro de decisões nacionais a extensão exata de suas demandas.

O repasse de competências às unidades periféricas deve vir acompanhado de instrumentos e de conteúdos que permitam a efetiva execução dos poderes concedidos aos entes agraciados com tais prerrogativas. A correta idealização das competências permite, sem dúvida, que ocorra o fortalecimento do sentimento de lealdade constitucional em todo o universo federativo, o que leva à redução ou à eliminação de conflitos e de dissensos interregionais que podem fragilizar a unidade do Estado. Urge, pois, compreender a dimensão maior impregnada aos mecanismos característicos do federalismo assimétrico, uma vez que a diferenciação dos entes federados, quando feita de forma controlada e consciente, acarretará importante técnica de pacificação dos Estados compostos, por isso

${ }^{284}$ A Democracia Possível, Ob. cit., p. 112. 
tem sido tão prestigiado pelo constitucionalismo erigido no período posterior ao término da Segunda Guerra Mundial ${ }^{285}$.

A despeito da pertinência da afirmação de que deve existir substancial correspondência entre os recursos atribuídos a uma esfera da Federação e as competências postas sob sua responsabilidade, sabe-se que o equacionamento dessa relação é sempre delicado, aumentando-se potencialmente o grau de complicação dessa empreitada em Estados federais que apresentem expressivas disparidades regionais ou locais, como é o caso do Brasil. Ciente das dificuldades apresentadas para o alcance desta fórmula, MANOEL GONÇALVES FERREIRA FILHO emprega uma analogia bastante significativa para a compreensão da problemática discutida. Diz que o perfeito equacionamento das competências titularizadas pelas unidades federativas, garantindo-lhes ainda compatíveis provisões de receitas, importaria em abraçar "um trabalho próximo do estabelecimento da quadratura do círculo" ${ }^{286}$, ou seja, quase impossível de se lograr o êxito idealizado, dadas as muitas contingências e variantes que interferem no cômputo do resultado apropriado e desejado.

Na sequência, após refletir acerca dos efeitos nefastos que uma estrita igualação competencial, assim como uma inflexível padronização na repartição de receitas, pode trazer para a estrutura federativa de um Estado, FERREIRA FILHO assevera que, tomada em seu aspecto formal, "uma repartição igualitária de competências, conjugada com uma divisão de rendas, que seja apenas uma distribuição, também igualitária, pode criar um círculo vicioso: como onde não há riqueza obviamente os tributos não rendem (ou rendem pouco), faltam meios para que o Estado federado possa bem exercer as competências recebidas. E isso tende a agravar as desigualdades, gerando tensões ameaçadoras para a federação e para a integridade do País"287.

Nesse compasso, outro dado que é considerado como de importância destacada para a projeção dos mecanismos de repartição de competência nos Estados que se utilizam das técnicas do federalismo assimétrico é recomendação de que as fórmulas de compartilhamento do poder político não sejam definitivas, imutáveis e eternas. A justificativa para essa advertência, como presumível, está no fato de que a assimetria tende a fazer com que as diferenças remediadas desapareçam com o passar do tempo, sendo

\footnotetext{
${ }^{285}$ Cf. Desiderio Fernández Manjón, Desafios de la Diversidad Territorial en los Estados Compuestos Asimétricos, Ob. cit., pp. 168-169.

${ }^{286}$ Constituição e Governabilidade: Ensaio sobre a (In)governabilidade Brasileira, São Paulo, Saraiva, 1995, p. 55.

${ }^{287}$ Constituição e Governabilidade: Ensaio sobre a (In)governabilidade Brasileira, Ob. cit., p. 55.
} 
assim, na medida em que todos os sujeitos federados evoluam, mostra-se conveniente proceder à revisão do sistema estabelecido ${ }^{288}$. Aliás, é justamente essa consciência política que faz com que países como a Suíça e a Bélgica ${ }^{289}$ estejam em permanente estado de revisão do texto constitucional para adaptá-lo satisfatoriamente ao aperfeiçoamento dos cenários políticos respectivos.

De antemão, interessa investigar se esse sistema dinâmico de estabelecimento de competências, caracterizado por sucessivas revisões, pode trazer ou não instabilidade institucional para as Federações que dele se valem. Acerca dessa discussão, posicionou-se DESIDERIO FERNÁNDEZ MANJÓN na direção de que os Estados compostos, que apresentaram sedimentação de um firme sentimento de lealdade constitucional entre as unidades político-administrativas, geralmente não sofreram nenhuma espécie de trauma em virtude da progressiva transformação das disposições constitucionais que disciplinam a repartição de competências. Ao revés, as situações de desgastes serão evitadas, na medida em que estas certamente ocorreriam se as reformas não fossem realizadas, porque, aos poucos, o déficit de eficiência e de governabilidade do Estado restaria percebido, tendo em vista a manifesta desconformidade das instituições políticas e dos documentos jurídicos com a realidade ${ }^{290}$.

Ainda informa FERNÁNDEZ MANJón que é "conveniente estabelecer, consensualmente, margens temporais para a tranquila reflexão, intervalos mínimos durante os quais as regras de repartição de competências e os instrumentos específicos de distribuição permanecerão inalterados [...]. É evidente que, com os ritmos de evolução da sociedade atual, tais intervalos não poderão ser muito grandes, nem intervalos muito breves, já que a brevidade produz desgastes que podem ser evitados. Com essas revisões periódicas das competências, é possível oferecer respostas adequadas aos legítimos direitos e aspirações das diversas regiões, tanto no que se refere ao repasse de competências de poder quanto no que é atinente à concessão de novas competências sobre temas não previstos e que surgiram com a própria evolução da sociedade"291.

\footnotetext{
${ }^{288}$ Cf. Desiderio Fernández Manjón, Desafios de la Diversidad Territorial en los Estados Compuestos Asimétricos, Ob. cit., p. 169.

${ }^{289}$ Com base nessa comprovação, esclarece PATRICK PEETERS que as assimetrias plasmadas ao federalismo belga apontam para a transformação das instituições centrais daquele país no resultado de um processo entendido como autêntico "direito contratual" entre as comunidades, já que as decisões mais importantes apenas são tomadas a partir do efetivo entendimento a que chegam as unidades político-territoriais daquele, Cf. Estado Federalismo: Uma Perspectiva Comparada. Bélgica se transforma de Estado Unitario em Estado Federal, in Asimetría Federal y Estado Plurinacional: El Debate sobre la Acomodación de la Diversidad en Canadá, Bélgica y España, Enric Fossas e Ferran Requejo (eds.), Ob. cit., p. 250.

${ }^{290}$ Cf. Desafios de la Diversidad Territorial en los Estados Compuestos Asimétricos, Ob. cit., p. 169.

${ }^{291}$ Idem, ibidem.
} 
Fica evidenciado, então, que a maior dificuldade operacional que o federalismo assimétrico encontrará para seu pleno desenvolvimento no Brasil estará em conseguir fazer com que as partes federadas compreendam a necessidade da instauração de um permanente diálogo institucional sobre o sistema de distribuição de competências existente no país. Ademais, a já explicitada dificuldade de reformar o texto da Constituição Federal, no que tange, especificamente, à incorporação dos mecanismos de diferenciação regional, também figurará como um provável obstáculo no país, caso não sejam repensados os critérios de composição das Casas Legislativas da União. Daí é que se conclui que a manutenção das atuais características da Federação nacional, em especial a percepção de inexpressivos índices de sentimento de lealdade federativa, pode ocasionar a frustração dos esforços de implantação de assimetria constitucionais.

Sobre o federalismo brasileiro, a obra de MARCElo PiAnCAStelli, RoGÉRIO BOUERI e EDILBERTO PONTES LiMA apresenta significativos registros que abonam as afirmações do parágrafo acima. Averbam os autores que, "além da uniformidade ou não das regras, outro ponto a ser apreciado nas relações intergovernamentais diz respeito à flexibilidade de tais regras. No Brasil, existe uma tendência à imposição de regras muito rígidas. Grupos sociais ou regionais, ao conseguirem a aprovação de seus pleitos, esforçam-se por cristalizar tais conquistas da forma mais permanente possível, muitas vezes buscando status constitucional. No entanto, a realidade econômica e institucional vem se mostrando cada vez mais dinâmica, e muitas vezes incompatível com estruturas demasiadamente rígidas" 292 .

A quebra da tradição de constitucionalizar todos os arranjos político-institucionais de maior importância político-social elaborados no país será um dos pontos que terá de ser trabalhado para viabilizar a adoção, em níveis expressivos, dos mecanismos relacionados ao federalismo assimétrico. Embora seja previsível a dificuldade de aceitação da proposta de flexibilizar a tendência de positivar, no texto jurídico de maior estabilidade, as normas disciplinadoras da diferenciação dos entes federados, parece ser essa a saída para expandir os ânimos de compatibilização da diversidade regional. A assimetria do Estado brasileiro, certamente, decorrerá muito mais das relações intergovernamentais empreendidas pelos entes federados do que de previsões diferenciadoras consignadas no texto da Lei Maior.

292 Descentralização Fiscal, Harmonização Tributária e Relações Intergovernamentais: como distintas Federações reagem aos desafios da globalização, in Desafios do Federalismo Fiscal, Fernando Rezende (coord.), Rio de Janeiro, FGV, 2006, p. 73. 
De fato, o dinamismo atualmente estabelecido pelos inconstantes paradigmas da realidade já requer a aplicação de formulações heterodoxas na estruturação do Estado federal. No Brasil, as cambiantes transformações que abalam as bases da Federação acabam sendo neutralizadas à margem da Constituição, uma vez que se atribui aos acordos políticos celebrados pelas diferentes unidades autônomas a função de tentar acomodar os pontos de tensão que podem desestabilizar a unidade do Estado. Por essa razão, o texto constitucional terá de trazer previsões que viabilizem a confecção dos referidos arranjos voltados ao tratamento dos fatores de complicação decorrentes da diversidade regional mais acentuada.

Visualiza-se, pois, que, muito mais do que reafirmar os valores de solidariedade no âmbito do federalismo nacional, a assimetria possivelmente irá desencadear a definição de novos padrões comportamentais para os entes políticos, na medida em que as atuações egoísticas tendem a ser abandonadas em prol da ação coordenada dos atores do conjunto. A partir dessa comprovação, ganha força a certeza de que, entre nós, a diferenciação federativa estará em poucas hipóteses consignada em expressos dispositivos constitucionais que estabeleçam posições estruturais assimétricas. Caberá, sem dúvida, ao exercício de competências constitucionais partilhadas corrigir as principais e mais problemáticas disparidades que poderão causar a desestabilização da Federação brasileira.

Por ter a Constituição vigente optado por assegurar a todos os Estados e Municípios autonomia política vertida numa organização formalmente igualitária ${ }^{293}$, é esperado que a atuação conjunta das unidades federadas alocadas nos três níveis de governo da Federação (o nacional, o regional e o local) compense, dentro de parâmetros razoáveis, as desigualdades apuradas. A partir desse processo, buscar-se-á promover, com precauções, o desenvolvimento de ações que tornem viáveis os programas implementados para a superar os conhecidos fatores ligados diretamente à heterogeneidade.

Esse entendimento é corroborado pela construção teórica que serve como suporte elementar para a justificação da assimetria federativa. Trata-se do seguinte raciocínio: se o tratamento dado pela Constituição a cada uma das entidades for absolutamente igualitário, certamente não será possível atingir um estado de equilíbrio, uma vez que as diferenças regionais tenderão a aumentar progressivamente. Um federalismo ideal - denominado de simétrico - pode não conduzir a bons resultados, haja vista que a descentralização política

${ }^{293}$ Cf. ANNA CÂNDIDA da CUNHA FERRAZ, Federalismo Simétrico e Federalismo Assimétrico. O Ajuste da Distribuição de Competências e de Recursos entre União, Estados e Municípios em Face de Vicissitudes de um Estado Moderno, in 10 anos de Constituição, IBDC (Instituto Brasileiro de Direito Constitucional) (coord.), Ob. cit., p. 53. 
operada deixará de acomodar satisfatoriamente todos os elementos de desagregação e de ineficiência governamental materializados no contexto estatal que se pretende amoldar ${ }^{294}$. Confirma-se, desse modo, a relevância dos arranjos assimétricos corporificados nas relações intergovernamentais em matéria de correção dos desníveis regionais.

O tratamento diferenciado de cada unidade autônoma poderá permitir que se construa um cenário de integração política e de aperfeiçoamento dos laços que mantêm as partes federadas unidas, conduzindo-as à consecução de objetivos comuns. Não reduzir os entes periféricos a modelos ideais é o primeiro passo para que o regime federativo consiga dar respostas adequadas às múltiplas demandas que são colocadas pelas variadas unidades autônomas. Além disso, a aplicação constante de relações intergovernamentais consonantes com as diferenças que existem em relação a cada um dos entes poderá dar azo ao surgimento de outra espécie de assimetria: a assimetria relacional. Essas assimetrias, antes inexistentes ou insignificantes nos Estados federais que formulavam ações governamentais sem admitir a heterogeneidade de suas peças, poderão ser convertidas em sérios problemas de governabilidade, caso os acordos recíprocos firmados pelas unidades autônomas não estiverem lastreados na precisa observância de alguns limites jurídicos, apresentados a seguir.

\section{III.4. Limites Constitucionais à Configuração Assimétrica do Estado Federal}

Fixada a diretriz que sufraga a percepção de que o Estado federal assimétrico pode adquirir tal qualificação porque é impelido por uma série de fatores ligados ao plano da realidade, cumpre, agora, esclarecer quais os limites jurídicos e políticos que devem ser observados nessa empreitada. Embora seja incontestável o fato de o federalismo proporcionar inesgotável incentivo à capacidade inventiva e de elaboração de arranjos governamentais responsáveis pela concretização do pacto federativo, quando as atenções se voltam à teoria da assimetria, é aconselhável que se delimite o espaço em que os arranjos assimétricos poderão ser realizados. É impensável deixar que o federalismo assimétrico assuma suas formas sem, no entanto, haver limites mínimos a serem respeitados.

No que diz respeito à importância de, aprioristicamente, fixarem-se áreas limítrofes nas quais essa vertente do federalismo poderá transitar, ESTHER SEIJAS VILLADANGOS

${ }^{294}$ Cf. Nelson Freitas Porfírio Júnior, Federalismo, Tipos de Estado e Conceito de Estado Federal, in Federalismo Fiscal, José Maurício Conti (org.), Ob. cit., p. 10. 
define que os instrumentos de compatibilização das diferenças regionais abrigados pela Constituição deverão guardar estrita observância aos comandos principiológicos emanados da ordem de igualdade, de unidade e de solidariedade entre os entes federados ${ }^{295}$. Por certo, caso os aludidos princípios deixem de ser seguidos, será grande a probabilidade de o regime federativo enfrentar situações de colapso e de insucesso. A adoção desorientada dos arranjos de assimetria aponta para o sempre temido risco de desmantelamento da Federação, o que, sem dúvida, acaba sendo um aspecto considerado por muitos Estados que relutam em aceitar a utilização dessa proposta em seus respectivos projetos de descentralização política.

Ratifica essas ideias JAVIER GARCÍA ROCA, ao sentenciar que um "certo grau de homogeneidade estrutural, competencial e financeira é inevitável em qualquer federalismo, e em todos os Estados, para assegurar sua governabilidade e a vigência dos princípios jurídicos de unidade, igualdade e solidariedade; o problema é determinar esse grau e encontrar um razoável ponto de equilíbrio entre assimetrias de fato e de direito e homogeneidade"296 . Desse modo, inevitável expor a constatação de que os construtores dos Estados compostos têm, no federalismo assimétrico, um aparato jurídico-institucional possível para a obtenção desse complicado e desafiador equilíbrio, mormente quando se está diante de Estados levantados em territórios que apresentam, sob as mais diferentes grandezas, disparidades acentuadas.

Em verdade, a chamada para a estrita observância dessas três linhas norteadoras da assimetria seria desnecessária, haja visa que a unidade, a solidariedade e a igualdade constituem pedras angulares da maior parte dos regimes federativos formados na contemporaneidade. Por isso é que alguns dos aspectos enfrentados a seguir já foram abordados sob prismas variados nos tópicos anteriores deste trabalho. Entretanto, a retomada dos mesmos mostra-se imprescindível nessa altura, pois agora esses tópicos antes analisados abstratamente - serão tratados com foco direto na preservação da harmonia e da operacionalidade dos Estados assimétricos.

Não obstante a obviedade que acompanha os predicados de igualdade, unidade e solidariedade federativas, não é demais realçar o cuidado que precisa ser constantemente alimentado para que o federalismo assimétrico, quando efetivamente colocado em prática, não conduza à perda de conquistas em matéria de descentralização política já consolidadas

${ }^{295}$ Cf. Ob. cit., pp. 431-441.

${ }^{296}$ España Asimétrica (Descentralización Territorial y Asimetrías Autonómicas: una Especulación Teórica), in Asimetría y Cohesión en el Estado Autonómico: Jornadas sobre el Estado Autonómico: Integración y Eficacia, INAP (Instituto Nacional de Administración Pública), Ob. cit., p. 61. 
nos Estados que o empregarem. Daí é apontada a conveniência de reforçar fortemente a vigília dos postulados em questão nos contextos assimétricos, pois, poderá acontecer de a instauração imatura da assimetria constitucional ser um passo incorrigível para o fim do próprio Estado federal, em vez de figurar como prometida solução a tensões históricas, até então, impossíveis de serem contornadas pelos métodos convencionais de organização espacial do poder político. Por tal razão é que se fará, a seguir, estudo em separado de cada um desses princípios, buscando-se apreciá-los sob a perspectiva da assimetria federativa, mais precisamente, colocando-os como verdadeiros elementos limitativos do federalismo promotor da dissimetria.

\section{III.4.1. O Princípio da Igualdade}

O tratamento formalmente igualitário de todos os componentes da Federação, embora represente postulado de muitos sistemas federativos, pode transformar-se em um mal a exigir ações corretivas, sob pena de corrosão gradativa dos laços associativos. A inércia do constitucionalismo e a despreocupação dos governantes em criar um regime federativo no qual a solidariedade represente uma construção sólida e operante podem trazer terríveis consequências ao Estado federal delineado sob tais condições ${ }^{297}$. Os efeitos deletérios de quadros assim colocados podem ir da ineficiência das políticas públicas esquematizadas até o surgimento de extremismos separatistas - esses, não raro, manifestados em ações terroristas e de franca intolerância com a diversidade -, por isso, o tema da compatibilização das heterogeneidades regionais é tão caro ao Direito Constitucional contemporâneo.

É grande a conveniência de admitir-se a assimetria como ferramenta habilitada a permitir a adequação do regime descentralizador arquitetado às necessidades que se originam de cenários territoriais onde há ásperas e marcantes disparidades. Nessa direção, esclarece DESIDERIO FERnÁNDEZ MANJÓn que, "na medida em que se avança no desenvolvimento democrático e na conquista da liberdade dos povos, a assimetria parece ser o traço mais comum, e talvez o mais conveniente, por meio do qual se garante o desenvolvimento da convivência interterritorial da diversidade dos povos" ${ }^{298}$. E esse amadurecimento democrático ecoa no campo da estruturas jurídicas dos Estados

${ }^{297}$ Cf. Dalmo de Abreu Dallari, Elementos de Teoria Geral de Estado, Ob. cit., p. 262.

${ }^{298}$ La Colaboración en el Estado Compuesto Asimétrico: El Caso de España, Ob. cit., p. 229. 
compostos, principalmente por meio da observância do princípio da igualdade material que, por extensão, é assegurado aos entes que formam a obra federativa.

Posicionamento afinado ao que já foi até aqui desenvolvido é esposado por FERNANDA DiAs MENEZES DE AlMEIDA, que assinala não haver motivos que justifiquem a negativa de aplicar-se o princípio da igualdade material no plano da organização federativa, de modo a permitir o florescimento de um regime não-simétrico que pretenda reduzir as desigualdades sociais e regionais ${ }^{299}$. Assinala ainda a autora que a intenção do constituinte brasileiro foi a de fazer com que essa diretriz principiológica fosse transformada no principal rumo orientador da concretização do objetivo fundamental da República Federativa do Brasil, consignado no art. $3^{\circ}$, inciso III, da Constituição ${ }^{300}$, o que, inexoravelmente, levará à determinação de tratamento diferenciado entre as unidades federadas, na precisa medida das desigualdades apresentadas por elas ${ }^{301}$.

A solução assimétrica sugere prestígio à singularidade tanto no tocante à fixação de competências quanto acerca da assunção de responsabilidades pelos entes autônomos, respondendo sempre aos imperativos de um processo de integração ajustado às necessidades e pretensões de cada comunidade federada. Enxerga-se ainda que as assimetrias, quando colocadas em prática numa Federação, poderão buscar ou garantir a permanência da diferença ou viabilizar uma organização político-administrativa que seja eficiente. No primeiro caso, as diferenciações estarão imbuídas da finalidade de proporcionar tratamentos específicos para situações particulares, acomodando-se demandas e exigências de cada coletividade; já no segundo, as assimetrias serão utilizadas com o objetivo de alcançar níveis satisfatórios de funcionalidade sistêmica, ou seja, buscam potencializar o desenvolvimento socioeconômico e a tendencial equivalência das condições de vida da população, independentemente do local em que os indivíduos se encontrem $^{302}$.

Entre nós, a noção de igualdade federativa, em sua matriz substantiva, tem amparo no comando constitucional que proíbe que se instituam distinções ou preferências entre brasileiros, a teor do art. 19, inciso III, da Constituição da República ${ }^{303}$. Sobre a extensão normativa que deve ser acreditada a esse preceito, vale fazer menção à emblemática

\footnotetext{
${ }^{299}$ Cf. Competências na Constituição de 1988, Ob. cit., p. 95.

300 “Art. $3^{\circ}$ Constituem objetivos fundamentais da República Federativa do Brasil: [...]

III - erradicar a pobreza e a marginalização e reduzir as desigualdades sociais e regionais".

${ }^{301}$ Cf. Competências na Constituição de 1988, Ob. cit., p. 95.

${ }^{302}$ Cf. Alessandra Silveira, Ob. cit., pp. 350-351.

303 “Art. 19. É vedado à União, aos Estados, ao Distrito Federal e aos Municípios: [...]

III - criar distinções entre brasileiros ou preferências entre si."
} 
decisão proferida nos autos da Representação $\mathrm{n}^{\mathrm{o}}$ 1.103-8-RJ, julgada pelo Pleno do Supremo Tribunal Federal, em 26 de agosto de 1982, cuja relatoria coube ao Ministro RAFAEL MAYER. Na ocasião, a Constituição de 1967, alterada pela Emenda Constitucional no 01 de 1969, trazia em seu art. 9, inciso I, disciplina literalmente idêntica ao dispositivo em comento, sendo que o Relator entendeu que o alcance a ser destinado a tal norma teria de estar em conformidade com a amplitude de seu sentido teleológico e de sua correlação com o princípio da isonomia, de forma a impor-se tratamento igualitário e harmônico aos vínculos federais, em que as autonomias se compõem sobre a unidade do Estado brasileiro $^{304}$.

Ao analisar a vedação insculpida no mencionado dispositivo da Lei Maior, José AFONSO DA SILVA registra que, com tal comando, a ordem constitucional brasileira atribui proteção "ao princípio federativo da unidade de nacionalidade de todos os brasileiros, qualquer que seja o Estado ou o Município de seu nascimento, bem como ao princípio da paridade entre as unidades da federação" ${ }^{305}$. Esclarece que a vedação de criar distinções entre brasileiros coliga-se com o princípio da igualdade, denotando que um ente federado não pode criar vantagens em favor de seus filhos em detrimento de originários de outros, cabendo fazer esse alerta também à União, que não poderá beneficiar nem prejudicar filhos de uns Estados ou Municípios ou do Distrito Federal mais do que filhos de outros. Já em relação à paridade federativa, essa prescrição proíbe que se façam preferências entre um Estado federado e outro, ou outros, ou entre os Municípios de um Estado ou de outro, ou do mesmo Estado ${ }^{306}$.

Em complemento, anote-se a impressão tirada por ANDRÉ RAMOS TAVARES de que o dispositivo constitucional em questão tem uma importante dimensão federativa, pois, além de determinar que haja idêntico tratamento para os indivíduos, coloca também a proibição de instituírem-se preferências entre os entes federados. A aludida regra,

\footnotetext{
${ }^{304}$ Cf. STF, Representação $\mathrm{n}^{\text {o }}$ 1.103-8-RJ, Relator Ministro RAFAEL MAYER, Pleno, data do julgamento: 26/08/1982, DJ 08/10/1982, p. 10.187, texto extraído de documento digital disponível no sítio eletrônico: http://www.stf.jus.br, acesso em 30/12/2009. Em direção oposta, JOSÉ CRETELLA JÚNIOR estatui que esse preceito constitucional não pode ser evocado para pleitear tratamento substancialmente igualitário às pessoas jurídicas, o que afastaria, por óbvio, a possibilidade de utilizá-lo como fundamentação para estabelecer medidas de compatibilização da diversidade territorial em prol dos entes federados, os quais, como se sabe, constituem pessoas jurídicas de direito público interno, Cf. Comentários à Constituição Brasileira de 1988, vol. 3, Rio de Janeiro, Forense Universitária, 1991, p. 1183.

${ }^{305}$ Curso de Direito Constitucional Positivo, São Paulo, Malheiros, 32 ${ }^{\mathrm{a}}$ ed., 2009, p. 476.

${ }^{306}$ Cf. Curso de Direito Constitucional Positivo, Ob. cit., p. 476. Perfilha de entendimento similar UADI LAMMÊGO BULOS, que anota ser essa vedação um importante preceito para a ordenação da solidariedade, vinculando a estrutura federativa a respeitar integralmente o princípio da igualdade (CF, art. $5^{\circ}$, caput) para que haja o correto funcionamento do pacto celebrado entre as unidades da Federação, Cf. Curso de Direito Constitucional, Ob. cit., pp. 752-753.
} 
conforme considerada, encontra tradução "na relação de respeito que deve vingar entre as entidades participantes da Federação, atribuindo-se a todas idêntico status, impedindo qualquer sorte de subordinação, que, de resto, desvirtuaria toda a forma federativa de organização" ${ }^{307}$. E é por tal razão que o federalismo assimétrico não pode significar, sob nenhum enfoque, preferência por uma entidade federativa em prejuízo das demais ou ainda a superioridade de um ente específico, cabendo à Constituição estabelecer os limites de eventuais assimetrias jurídicas necessárias ${ }^{308}$.

Percebe-se, então, ser inadmissível o emprego da técnica da assimetria sem integral respeito ao postulado da igualdade vertido em sua manifestação substancial, uma vez que os privilégios de qualquer sorte não encontram guarida no ambiente federativo, consoante dispõe o art. 19, inciso III, da Lei Maior. Na órbita do Estado federal, competirá a esse comando principiológico assumir a condição de um dos critérios (talvez o principal) que permitirá o desenvolvimento das assimetrias jurídicas com segurança e adequação, cuidando-se para que a diferenças regionais, quando acomodadas mediante o emprego de formas assimétricas, não violem nem a igualdade entre os indivíduos, nem tampouco a igualdade dos entes federados. O cumprimento integral desse mandamento, assim como de outros voltados à coexistência harmoniosa das partes amarradas pelo pacto federativo, representa condição inafastável para que seja possível a cooperação e a solidariedade federativas, bem como haja o gradativo estabelecimento de indicadores sociais assemelhados em todas as regiões ${ }^{309}$.

Em resumo, conclui ESTHER SEIJAS VILLADANGOS que "a compatibilidade entre assimetria e igualdade origina-se da compreensão deste último princípio, em sua acepção substantiva ou material, não como algo absoluto, mas como um critério cujo nível efetivo de realização pode oscilar, sempre a partir do cumprimento de um mínimo irrenunciável”310. Esse mínimo a ser considerado diz respeito ao atendimento de direitos fundamentais básicos do indivíduo ou de grupos sociais determinados, colocando-se ao Estado federal a obrigação de assegurar a todos que a fórmula política da descentralização do poder cuidará para que os níveis elementares de prestabilidade dos serviços públicos sejam atendidos a contento, não importando em qual parte do território da Federação a pessoa ou o agrupamento social se encontra, já que a igualdade entre as unidades

\footnotetext{
${ }^{307}$ Curso de Direito Constitucional, 7ª ed., São Paulo, Saraiva, 2009, p. 1062.

${ }^{308}$ Cf. André Ramos Tavares, Curso de Direito Constitucional, Ob. cit., p. 1048.

${ }^{309}$ Cf. AlesSANDRA Silveira, Ob. cit., pp. 355-356.

${ }^{310}$ Cf. Ob. cit., p. 441.
} 
subnacionais pressupõe que iguais direitos sejam disponibilizados, numa mesma intensidade, sem qualquer discriminação de cunho geográfico.

Desse modo, propugna-se que, para existir verdadeira igualdade no tratamento dado à pessoa humana pela Federação, será preciso corrigir os aspectos da desigualdade dos entes federados que causam profundos impactos na estruturação do conjunto federativo. Há de se ter em mente que "a homogeneidade social é a base concreta para a formação da unidade política"311, pois o princípio da igualdade constitui referência imprescindível da convivência política, devendo essa principiologia ser fielmente observada, inclusive, na interação entre as unidades que integram o Estado federal, caso contrário o federalismo estará apartado dos valores que informam a ordem constitucional brasileira que, como sabido, perfaz-se num Estado Democrático de Direito. Em última instância, impende certificar que o que irá justificar todos os arranjos assimétricos é a preocupação em atender às necessidades básicas do ser humano, ajustando-se, se preciso, mediante aplicação de prescrições normativas, os desníveis fáticos que dificultam atingir a esse elevado propósito.

\section{III.4.2. O Princípio da Unidade da Federação}

A principiologia que rege a unidade do Estado federal deve estar inexoravelmente presente em todas as estruturas jurídicas e políticas que servem de alicerce para a construção de edifícios federativos. Não é sem motivo que, já no art. $1^{\circ}$ da Constituição Federal de 1988. é declarado expressamente que a República Federativa do Brasil é “formada pela união indissolúvel dos Estados e Municípios e do Distrito Federal”. Esse preceito, em virtude de constituir fundamento da ordem constitucional nacional, terá de ser evocado toda vez que se desejar entender a lógica que guia a Federação insculpida na Lei Maior em vigor.

De tal sorte, a correta compreensão desse princípio representa etapa imprescindível para a segura elaboração dos institutos que serão utilizados na difícil tarefa de compatibilizar-se, dentro de parâmetros de harmonia, a implacável diversidade que pode manifestar-se no meio social como reflexo direto da interatividade dos inúmeros quadros territoriais que se comunicam no sistema federativo. Ademais, numa visão da Federação à luz das diretivas apontadas pela axiologia que informa a democracia, exige-se, de plano, o

\footnotetext{
${ }^{311}$ Agassiz Almeida FILHo, Fundamentos do Direito Constitucional, Rio de Janeiro, Forense, 2007, p. 93.
} 
afastamento de qualquer pressuposição no sentido de que os interesses regionais promovidos pelos entes subnacionais colidiriam ou seriam incompatíveis com os interesses superiores do Estado.

É com arrimo nos ensinamentos de José AlFREDO DE OLIVEIRA BARACHO que se chega à crença de que "a auto-organização da sociedade não exclui o princípio da unidade política, desde que a unidade que se procura, por meio do consenso, é a que se efetiva na pluralidade" ${ }^{, 312}$. Por influxo do pluralismo, tem-se ainda que o alcance da unidade na diversidade, tão importante para o Estado federal, não pode ser traduzido na completa supressão da estrutura social muitas vezes conflitante, uma vez que compete ao Direito funcionar como meio de composição de conflitos eventualmente formados entre os corpos políticos parciais e o poder central. E, nessa delicada missão, a conciliação e a tolerância deverão servir ao pensamento jurídico como recursos de pacificação da convivência comunitária $^{313}$.

A unidade retrata, pois, o compromisso a ser observado por todos os atores do conjunto federativo com a intenção de possibilitar a efetivação dos mandamentos cardeais que orientam o ordenamento constitucional e ainda possibilitam a formalização de um vigoroso pacto federativo. Em outras palavras, é a unidade que permite aos entes federados o exercício da auto-organização sem que a multiplicidade de ordens jurídicas subnacionais acarrete a corrosão dos valores e dos interesses responsáveis pela manutenção dos primaciais aspectos associativos da Federação.

Exatamente nessa direção, ENRICO CARLONI explicita que o conteúdo desse importante princípio pode ser traduzido, em linhas gerais, como a qualidade de um sistema no qual reina, com primazia, um regime jurídico nacional (a ordem federal) ao lado da multiplicidade de outras ordens jurídicas regionais (Constituições estaduais, por exemplo), sem que isso implique uma preocupante potencialidade de diferenciação das partes que integram o todo ${ }^{314}$. A unidade interpretada em consonância com as ideias derivadas do pensamento pluralista certamente assegura que os entes federados gozem de posições diferenciadas uns em relação aos outros, porém essa técnica, ao ser empregada, jamais poderá fazer com que a proteção dos interesses de parcelas específicas dos entes faça com que haja a negativa de valores essenciais para todos os integrantes do pacto federativo.

\footnotetext{
${ }^{312}$ O Princípio da Subsidiariedade: Conceito e Evolução, Ob. cit., p. 24.

${ }^{313} \mathrm{Cf}$. Idem, ibidem.

${ }^{314}$ Cf. Ob. cit., p. 25.
} 
Assim é que, com subsídio na obra de MARCElo Neves, pode-se enxergar que as relações recíprocas de poder entrelaçadas entre o poder central e os poderes regionais e locais denotam evidente exemplo do que se denomina de "transconstitucionalismo", teoria na qual se vislumbra o "constitucionalismo relativo a (soluções de) problemas jurídicoconstitucionais que se apresentam simultaneamente a diversas ordens"315. A instrução primeira que direciona a compreensão do fenômeno do transconstitucionalismo está justamente no desenvolvimento de institutos constitucionais que sejam habilitados a permitir a instauração de relações construtivas de aprendizado e de intercâmbio entre todas as ordens jurídicas que se inter-relacionam ${ }^{316}$.

Ainda anuncia NEVES que, no campo das assimetrias, o transconstitucionalismo permite identificar o fato de que determinadas ordens e culturas jurídicas estatais, geralmente aquelas dotadas de expressiva força, inclinam-se para a tendência de atuar destrutivamente em face aos demais atores políticos menos prestigiados. Explica também que "as instâncias centrais do Estado, frequentemente, não estão dispostas a suportar formas de direito locais e colaborar com elas. Disso resulta a opressão das pretensões jurídicas locais em nome da unidade estatal. [...] Muitas vezes, os efeitos destrutivos recíprocos surgem no âmbito dos conflitos entre pretensão de unidade de um Estado federal, regional ou unitário e as pretensões de autonomia de seus respectivos Estadosmembros, regiões ou províncias/departamentos ${ }^{\text {"317 }}$. Do exposto, fica patenteado que as frequentes interações entre as variadas esferas de governo não podem, em absoluto, ensejar quadros de intolerância e de negação do pluralismo, já que somente ordenamentos desajustados apresentam tais sintomas.

Numa última síntese, coloca-se que as técnicas elaboradas para promover o respeito à diversidade estão proibidas de criar obstáculos ao alcance de níveis mínimos de unidade na Federação. Independentemente das fórmulas jurídicas desenvolvidas para acomodar as disparidades regionais, a adoção de inclinação diversa resultará não na esperada configuração de um Estado territorialmente composto em condições sustentáveis de equilíbrio, mas numa organização estatal que caminha para a desintegração e que perderá em eficiência governamental. Nessas organizações estatais o pacto federativo soldado indica que o sistema de atuação recíproca operacionalizado não está suficientemente capacitado para cuidar da diversidade que se origina no meio social.

\footnotetext{
315 Transconstitucionalismo, São Paulo, WMF Martins Fontes, 2009, p. 129.

${ }^{316}$ Cf. MARCELo NeVES, Transconstitucionalismo, Ob. cit., p. 130.

${ }^{317}$ Idem, p. 283.
} 
Há de se ter como correto, portanto, que o diálogo entre o todo e as partes do Estado federal, caso não não seja um frutífero meio de superação dos problemas comuns colocados ao conjunto, deverá ser interpretado como sinal indicativo de desgaste e de incorreção da estrutura federativa. Quando isso ficar comprovado, a assimetria federativa será peça de extremada relevância para reenquadrar as relações de poder que estarão com algum grau de nocividade. Daí a razão que nos faz acreditar que o pluralismo devidamente estruturado não pode prescindir do federalismo assimétrico, pois a acomodação das diferenças regionais que podem atravancar a construção de um regime federativo conveniente para todas as unidades autônomas constitui-se em salutar medida para todo o conjunto.

\section{III.4.3. O Princípio da Solidariedade}

Consoante anota ESTHER SEIJAS VILLADANGOS, o princípio da solidariedade ${ }^{318}$, ao ser interpretado em sintonia com as ideias informadoras da assimetria, assume a condição de limite ao exercício das competências franqueadas às unidades autonômicas, uma vez que se transmuta em norte seguro para a compreensão da finalidade que regerá o desempenho do autogoverno garantido aos entes. Também servirá como o elemento impulsionador da existência de previsões constitucionais diferenciadoras, colocadas no texto normativo para resguardar condições particulares identificadas em face de determinados entes federados. Por certo, é o solidarismo o ponto que justifica a integração de todas as unidades federativas em um único projeto político, qual seja, a construção de um vigoroso conjunto de instituições aptas a fazer do Estado Federal um eficiente recurso de superação das desigualdades ${ }^{319}$.

O texto constitucional, quando consagra a solidariedade como vetor axiológico do regime federativo que estabelece, está indicando que as diversas instâncias autônomas deverão participar não somente das discussões sobre os interesses comuns da Federação,

\footnotetext{
318 Não obstante a doutrina costumeiramente utilizar os vocábulos "solidariedade" e "cooperação" como sinônimos da principal característica do federalismo cooperativo, DESIDERIO FERNÁNDEZ MANJÓN apresenta aspectos que distinguem esses dois termos. Explica ele que "enquanto a solidariedade transmite um princípio de índole altruísta, a cooperação pode significar, em numerosas ocasiões, um sentido egoísta, como na hipótese de colaborar-se para a obtenção de algum tipo de vantagem; somente em determinadas circunstâncias é que a cooperação poderá ser identificada com a solidariedade. O solidarismo, assim, tem mais sentido na colaboração unilateral ou em casos em que a cooperação bilateral ocorre porque a parte que receberá a ajuda enfrenta situação mais precária", La Colaboración en el Estado Compuesto Asimétrico: El Caso de España, Ob. cit., p. 233.

${ }^{319}$ Cf. Ob. cit., p. 435.
} 
mas, sobretudo, que todas as unidades autônomas terão de se preocupar com questões relacionadas diretamente a alguns dos entes federados. Daí o motivo de se enfatizar que as ações provenientes do comando de solidariedade deverão ser exercidas entre o poder central e as unidades subnacionais, bem como entre estas, consideradas as possíveis interações governamentais que surgirão de relacionamentos praticados somente pelos atores regionais do Estado federal. As variadas formas de assunção do caráter solidário permitem assegurar ao federalismo assimétrico, no mínimo, três diferentes maneiras de conformação: a solidariedade da União com as partes periféricas (Estados e Municípios); a solidariedade inter-regional (que se desenvolve entre os Estados-membros); e a solidariedade intrarregional (manifestada por meio da colaboração entre órgãos e unidades governamentais situados em diferentes localidades de um mesmo território) ${ }^{320}$.

No terreno da colaboração federativa, o aspecto que sempre suscita singular interesse é o "problema da compatibilidade entre o caráter voluntário da cooperação e sua configuração como dever jurídico" ${ }^{321}$. Seja como princípio constitucional ou consequência do voluntarismo que coloca em movimento os entes federados, ALESSANDRA SILvEIRA indica que a cooperação no Estado federal traz consigo um compromisso derivado da aglutinação e da manutenção dos laços associativos arregimentados com a instauração do pacto federativo e, a partir desse entrelaçamento de atuações, pode-se visualizar duplo enfoque: uma dimensão ativa e uma dimensão passiva; sendo a natureza jurídica dessa prática constatada somente no tocante à segunda acepção possível da cooperação, o que, por via reflexa, autoriza admitir o sentido passivo da interação governamental como expressão da atuação guiada pela vontade política dos respectivos integrantes do concerto federativo $^{322}$.

O aspecto passivo da cooperação, elevado ao status de norma constitucional, “implica a moderação recíproca, a abstenção do exercício de poderes formalmente acometidos quando tal eventualmente comprometa o sucesso da totalidade sistêmica, a proibição da omissão de auxílio" ${ }^{323}$. Essa vertente da colaboração, na prática, impõe aos entes autônomos a proibição de perturbar a consecução dos interesses alheios, bem como determina que se reprovem decisões governamentais que denotem desapreço à Federação. Posicionamento, a propósito, confirmado por KONRAD HESSE, que propugna ser o princípio da conduta federativa amistosa uma norma constitucional imanente, responsável pelo

\footnotetext{
${ }^{320}$ Cf. Esther Seijas Villadangos, Ob. cit., p. 435.

${ }^{321}$ AlESSANDRA SilveIRA, Ob. cit., p. 446.

${ }^{322}$ Idem, pp. 451-457.

${ }^{323}$ AlessandRA SilveIRA, Ob. cit., p. 451.
} 
estabelecimento de uma ordem fundada na colaboração recíproca entre todos integrantes do Estado federal ${ }^{324}$.

Já no que respeita à faceta ativa da cooperação, como já anunciado, mostra-se inviável atribuir-lhe natureza jurídica, haja vista que requer ela atores decididamente empenhados na atuação concertada. A voluntariedade é marcante nessa atuação, e eventual previsão constitucional de comportamentos obrigatórios na seara de cooperação intergovernamental refletir-se-á como prejudicial à faculdade de autodeterminação dos entes político-administrativos de um Estado composto. Mesmo quando a Constituição obrigar expressamente que os diferentes entes federados prestem atendimento conjunto às necessidades da população (a exemplo das competências materiais comuns previstas no art. 23 da Constituição Federal de 1988), não se pode falar em normatização da cooperação federativa, pois o que está encartado na norma constitucional é tão-somente o dever de atuação conjunta, sem nenhum juízo acerca do tratamento uniforme ou diferenciado de uma dada matéria ou setor a ser delimitado no momento de ação ${ }^{325}$.

A impossibilidade de definir constitucionalmente o conteúdo ativo das práticas relacionais derivadas do federalismo cooperativo, não cerceia, no entanto, a conjugação entre solidariedade e assimetria como proposta sustentável para vencer o desafio de superação das desigualdades regionais. Nessa esteira, defende-se que a promoção do solidarismo federativo pretende fazer da Constituição a mais importante garantia de que a Federação seja um eficiente sistema de descentralização política do poder, no qual haja justiça e equilíbrio na produção e distribuição de riquezas. Assim, compreeder que a solidariedade é um dos limites a ser observado pelo federalismo assimétrico não deixa de ser uma antevisão da imprescindível função amortizante que a colaboração ocasionará aos prováveis efeitos negativos que podem se originar das assimetrias colocadas em funcionamento nos mais diferentes Estados federais ${ }^{326}$.

Cumpre assinalar ainda que a atuação concomitante de múltiplas esferas de poder não pode ser autista ou egoisticamente conduzida, uma vez que cada ente político terá de estar comprometido com a construção de um conjunto harmônico e coordenado. A sintonia com os propósitos maiores do federalismo certamente irá fazer com que o horizonte federativo elimine as contradições e as disfunções que impeçam a integração sistemática e

\footnotetext{
${ }^{324}$ Cf. Elementos de Direito Constitucional da República Federal da Alemanha, Ob. cit., p. 214.

${ }^{325}$ Cf. Alessandra SilveIRA, Ob. cit., p. 452.

${ }^{326}$ Cf. Esther Seijas Villadangos, Ob. cit., pp. 435-436.
} 
funcional das distintas esferas competenciais ${ }^{327}$. Caberá, assim, ao princípio da solidariedade - interpretado sempre em direta consonância com a noção de unidade federativa - garantir que as incoerências identificadas na Federação sejam tratadas dentro da estrita proporcionalidade e razoabilidade esperada para a harmonização do regime estabelecido, atribuindo-se tratamento diferenciado apenas às unidades que, de modo comprovado, realmente precisarem desses cuidados assimétricos.

A cooperação federativa obstaculiza, pois, que o Estado assimétrico, quando estruturado, tome rumos que vulnerem seus elevados propósitos de criação. $\mathrm{O}$ abandono gradativo de conceitos inflexíveis que tradicionalmente apresentavam-se arraigados à configuração dos Estados aponta para o fato de que os vetustos conceitos de centralização, simetria, igualdade e homogeneização territorial vêm sendo superados conforme o diálogo entre as distintas realidades do universo federativo avança e permite a instauração de novos paradigmas de coesão e de manutenção da diversidade ${ }^{328}$. Aliar a cooperação entre governos com a assimetria permite que se desenvolvam salutares comportamentos solidários, os quais certamente funcionarão como eficientes mecanismos de defesa dos excessos que podem decorrer do manuseio inadequado dos engenhos vinculados à diferenciação territorial.

${ }^{327}$ Cf. Alessandra Silveira, Ob. cit., p. 327.

${ }^{328}$ Cf. Desiderio Fernández Manjón, La Colaboración en el Estado Compuesto Asimétrico: El Caso de España, Ob. cit., p. 229. 


\section{O ESTADO FEDERAL BRASILEIRO: UM CONCERTO SIMETRICAMENTE ASSIMÉTRICO}

\begin{abstract}
“[...] no Brasil, a luta pelo federalismo está ligada às aspirações de desenvolvimento das distintas áreas. Não se coloca o problema de choque de nacionalidades, de agressões culturais ligadas a disparidades étnicas ou religiosas. Mas sim o da dependência econômica de certas regiões com respeito a outras, da dissimetria nas relações, de transferências unilaterais de recursos encobertas em políticas de preços administrados".
\end{abstract}

Celso Furtado 329

\section{IV.1. A Federação Esculpida pelas Elites Regionais}

Apesar da anunciada vocação federativa demonstrada pelo Brasil ${ }^{330}$, condicionada por fatores naturais e geográficos ligados à vastidão do território e à existência de "um colorido mosaico de condições econômicas variando ao infinito" 331 , o processo de criação do Estado federal nacional foi forjado a partir de sucessivas etapas de conciliações políticas, iniciadas durante a vigência do regime monárquico. No país - como em todo o continente americano -, o processo de constitucionalização firmado no início do século XIX foi influenciado grandemente pela independência das antigas colônias europeias e obedeceu, com rigor, à lógica de fundir a organização jurídica do Estado com certo grau de ideologia política. O liberalismo assumiu, pois, muito mais do que o caráter de luta pela liberdade política do povo, representou o elemento informador da fundação da

\footnotetext{
${ }^{329}$ Ob. cit., p. 39.

${ }^{330}$ Sobre esse ponto, PINTO FERREIRA afirma haver uma predestinação histórica do Brasil ao Estado Federal, apontando que o motivo primordial que serviu de causa ao florescimento da Federação no país foi "a própria imensidade territorial obrigando a uma descentralização de governo, a fim de manter a pluralidade das condições regionais, o regionalismo de cada zona, tudo integrado na unidade nacional no federalismo" (Cf. Curso de Direito Constitucional, $7^{\mathrm{a}}$ ed., São Paulo, Editora Saraiva, 1995, p. 265). Alinham-se a essa orientação, entre outros, RuI BARbosa, Comentários à Constituição Federal Brasileira, vol. I, São Paulo, Saraiva, 1932, pp. 52-54; MARCElo CAETANO, Direito Constitucional - vol. II: Direito Constitucional Brasileiro, Rio de Janeiro, Editora Forense, 1978, pp. 43-44; CLÁUdIo PACHECO, Tratado das Constituições Brasileiras, vol. I, Rio de Janeiro, Freitas Bastos, 1958, pp. 330-331; OllveIRA ViannA, Evolução do Povo Brasileiro, $3^{\mathrm{a}}$ ed., Rio de Janeiro, Editora Nacional, 1938, p. 305-310; CÁRMEN Lúcia ANTUNES RochA, $O b$. cit., p. 199; e Victor VianA, A Constituição dos Estados Unidos: As Lições de uma Longa Experiência Federalismo Norte-americano e Federalismo Brasileiro, Rio de Janeiro, Jornal do Comércio, 1933, p. 213.

${ }^{331}$ Cf. Joño CAmillo de Oliveira Torres, A Formação do Federalismo no Brasil, São Paulo, Companhia Editora Nacional, 1961, p. 184.
} 
personalidade do Estado e embutiu-se na natureza institucional das estruturas de poder criadas $^{332}$.

Naquele contexto, o princípio liberal foi adotado com ampla aceitabilidade, porque atendia convenientemente às aspirações das classes dominantes que protagonizavam o cenário político da época. Com efeito, registra DANIEL J. ELAZAR que, no período aludido, a maioria dos Estados recém-independentes da América Latina buscou inspiração no modelo estadunidense de descentralização política, sem, no entanto, deixar de receber as variadas influências decorrentes da tradição imperial hispânica, a exemplo do acentuado poder decisório das lideranças regionais responsáveis pela formação do denominado caudilhismo $^{333}$. Evidentemente, no Brasil, guardadas as especificidades da colonização lusitana, não foi diferente ${ }^{334}$.

Aqui, as elites regionais levantaram a bandeira federalista para colocar termo ao centralismo e, por conseguinte, amainar o excessivo poder estatal que sufocava os impulsos autonomistas. Enfatiza ROSA MARIA GODOY SILVEIRA que, naquele contexto, "nas discussões sobre o federalismo no Brasil, os clamores contra a centralização escondiam verdadeiramente clamores contra um Estado que açambarcava todas as esferas - econômica, social, política, administrativa - da vida nacional, contrariando determinados interesses dos setores mais dinâmicos da sociedade, desejosos de se expandir" ${ }^{335}$. Daí porque, nos primeiros períodos do federalismo, o ideal de descentralização política mostrou-se imprescindível para atender os ímpetos de liberdade tão abertamente propagados $^{336}$.

A verdade é que o regime federativo fincou seu domínio sobre determinados segmentos da política nacional muito antes da proclamação da República, em especial

\footnotetext{
332 Cf. Afonso Arinos de Melo Franco, Estudos de Direito Constitucional, Revista Forense, Rio de Janeiro, 1957, p. 225. Acerca da relação existente entre liberalismo, República e democracia - três conceitos que tiveram papéis decisivos nessa etapa da história latino-americana -, consultar OsCAR GODOY ARCAYA, Republicanismo, Liberalismo y Democracia, in Estudios Públicos, no 99, 2005, pp. 241-256, e NoeliA GonZÁlez ADÁNEZ, Liberalismo, Republicanismo y Monarquía Absoluta: los Proyectos de Reforma para América en la Segunda Mitad del Siglo XVIII Español, in Revista de Estudios Políticos, no 113, 2001, pp. 359-369. E ainda, para a compreensão detalhada da influência do pensamento liberal na proclamação da República no Brasil, verificar RAYMundo FAORo, Os Donos do Poder: Formação do Patronato Político, $3^{\mathrm{a}}$ ed., São Paulo, Globo, 2001, pp. 503-535; e CeZAR SAldanha SouZA Junior, Consenso $e$ Constitucionalismo no Brasil, Porto Alegre, Sagra Luzzatto, 2002, pp. 58-73.

${ }^{333}$ Ob. cit., p. 150.

${ }^{334}$ Sobre o descompasso entre o modelo federativo dos Estados Unidos e as conjunturas latino-americanas pós-independência, ver Janice Helena Ferreri, A Federação, in Por uma Nova Federação, Celso Bastos (coord.), São Paulo, Revista dos Tribunais, 1995, pp.15-17.

${ }^{335}$ Republicanismo e Federalismo: um Estudo da Implantação da República Brasileira (1889-1902), Brasília, Senado Federal, 1978, p. 59.

${ }^{336}$ Cf. Aureliano CÂndido TAVARes Bastos, A Província: Estudo sobre a Descentralização no Brasil, $3^{\text {a }}$ ed., São Paulo, Editora Nacional, 1975, p. 35.
} 
depois da edição do Ato Adicional de $1834^{337}$. O progressivo acatamento do Estado federal no Brasil não teve, como lastros determinantes, fatores de ordem histórico-geográfica ${ }^{338}$; foi ocasionado, sem dúvida, pelo reconhecimento de que uma nação, para existir, não precisa ser rigorosamente homogênea, deve antes - sobretudo na ocasião de sua construção - obter êxito na arquitetura de uma unidade política harmoniosa em relação aos condicionantes de ordem econômica e social. Nessa empreitada, transparece ter sido a necessidade de acomodar múltiplas pretensões regionais conflitantes, as quais traduziam os interesses encabeçados pelas respectivas lideranças locais, o principal elemento deflagrador do federalismo brasileiro ${ }^{339}$.

O unitarismo manteve-se vigoroso enquanto houve identificação entre economia e participação política. Entretanto, como consequência do deslocamento do centro dinâmico da economia do país, nos anos posteriores a 1850, observou-se a instauração do desequilíbrio entre o poder econômico e o poder político. Esse fator foi decisivo para que surgissem árduos conflitos entre as elites dirigentes, bem como para o fortalecimento da aspiração federalista ${ }^{340}$, entre aqueles atores responsáveis pela manipulação do poder ideológico $^{341}$.

\footnotetext{
${ }^{337}$ Há forte inclinação, na doutrina brasileira, em admitir que os valores inerentes à Federação mostraram-se presentes no pensamento político das elites nacionais muito antes do esfacelamento do Império, conforme se depreende das obras de Miriam Dolnnikoff, O Pacto Imperial: Origens do Federalismo no Brasil do Século XIX, São Paulo, Globo, 2005, pp. 1-330; JoÃo CAMILlo DE OliveIRA Torres, Ob. cit., pp. 82-151; Waldemar Ferreira Martins, História do Direito Constitucional Brasileiro, São Paulo, Max Limonad, 1954, pp. 61-69; Paulo Bonavides, A Constituição Aberta: Temas Políticos e Constitucionais da Atualidade, com ênfase no Federalismo das Regiões, $3^{\text {a }}$ ed., São Paulo, Malheiros, 2004, pp. 340-342; Augusto Zimmermann, Ob. cit., pp. 289-290; Oswaldo Ferreira de Mello, Tendências do Federalismo no Brasil, Florianópolis, Lunardelli, s/d, p. 40-44, LuIs RoBerto BARroso, Direito Constitucional Brasileiro: O Problema da Federação, Rio de Janeiro, Forense, 1982, pp. 30-31; Oliveira Vianna, Ob. cit., p. 302-304; Rosah Russomano, Ob. cit., pp. 39-45; Fábio Cirino Peixoto, Teóricos da Véspera: o Federalismo no Pensamento Político do Brasil Império, Dissertação de Mestrado, Faculdade de Filosofia, Letras e Ciências Humanas da USP, São Paulo, 2005, pp. 7-10. Nesse mesmo sentido, cabe destacar ainda paradigmático precedente da Corte Constitucional brasileira: STF, ADI n 3.148-TO, Pleno, Relator Ministro CELSO DE Mello, julgamento: 13/12/2006, DJ 28/09/2007, p. 26 (voto do Relator).

${ }^{338}$ MiRIAm DOLHNIKOFF registra o quão difícil foi a compatibilização, em uma mesma unidade política, de territórios que, além da gritante diversidade territorial, contavam com poucos e frouxos laços de integração e cujas elites apresentavam demandas muitas vezes contraditórias entre si. Na América portuguesa emergente do período colonial, as províncias que passaram a compor o Império representavam um conjunto de regiões distintas, cuja unidade não existia e estava muito longe de se consolidar, sendo que tal relação institucional somente foi construída ao longo do século XIX, Cf. Ob. cit., pp. 23-24.

${ }^{339}$ Como assevera José MuRILO DE CARVALHO, o Império, não se distanciando do arcabouço instaurado no período de pré-independência, logrou, ao menos durante os anos de sua existência mais pujante, manter coesa a elite, o que significou a redução dos conflitos internos entre os grupos dominantes e a neutralização da possibilidade de eclosão de revoltas mais amplas na sociedade, Cf. A Construção da Ordem: a Elite Política imperial. Teatro das Sombras: a Política Imperial, Rio de Janeiro, Civilização Brasileira, 2003, p. 40.

${ }^{340}$ Cf. Rosa Maria Godoy Silveira, Ob. cit., pp. 66-67.

${ }^{341}$ A caracterização, a relevância e as funções desempenhadas no meio social pelo poder ideológico, exercido pelos intelectuais, são apresentadas por NORBERTO BOBBIO, Cf. Os Intelectuais e o Poder: Dúvidas e Opções
} 
As divergências e os conflitos gerados pelas transformações que se processaram na estrutura do país naquela época, agravados pelo fim da escravidão e pelo alto custo representado pela Guerra do Paraguai, colocara em xeque as instituições e as estruturas ligadas ao centralismo. Projetou-se, então, numa dimensão antes inimaginável, a ideia de que a integridade nacional dependeria em demasia do êxito a ser alcançado no processo de fragmentação do poder. A teoria federalista, desenvolvida e aplicada com alardeado sucesso nas antigas colônias britânicas da América do Norte, tornou-se a fonte direta de inspiração da classe política dominante, que estava insatisfeita com o Estado unitário.

Esse período conturbado da história brasileira é ilustrado por GILBERTO BERCOVICI, que aponta relevantes fatores de índole socioeconômica que interferiram na implantação de nosso Estado federal. Registra o autor que: “As regiões fornecedoras da maior parte dos estadistas do Império, o Norte açucareiro e os núcleos cafeicultores do Rio de Janeiro, estavam em crise. $\mathrm{O}$ novo centro econômico era o oeste paulista. Alçado à condição de motor do desenvolvimento do país, São Paulo se sentia prejudicado e discriminado pela centralização. Dessa forma, de todas as Províncias, São Paulo era aquela em que os republicanos estavam em maior número e melhor organizados. No caso paulista, a defesa do republicanismo com federalismo tinha como motivo o desejo de aumentar seus recursos: os republicanos defendiam uma redistribuição das rendas para que São Paulo pudesse financiar os custos de sua economia em expansão, baseada no café" ${ }^{342}$.

O crescimento das dívidas interna e externa do Brasil em razão do conflito armado ocorrido na Bacia do Rio da Prata comprometeu o orçamento do Estado imperial e imobilizou a disponibilização de receitas públicas para o atendimento das variadas necessidades elencadas pelas Províncias existentes. Ao contrário do que antes acontecia, a Corte não mais podia recorrer a políticas generalizantes, pois as demandas provinciais estavam se tornando muito distintas, graças aos diferentes ciclos econômicos que cada

dos Homens de Cultura na Sociedade Contemporânea, São Paulo, Editora da Universidade Estadual Paulista, 1997, pp. 9-12.

${ }^{342}$ Dilemas do Estado Federal Brasileiro, Ob. cit., pp. 29-30. Integraliza esse dado WiLma Peres CosT A, ao explicitar que "tanto o Norte como o Sul, por motivos distintos, tendiam a insurgir contra a centralização fiscal. No nível ideológico, as disputas tendiam a manifestar-se em acusações mútuas. As províncias do Norte e Nordeste apegavam-se à questão dos saldos provinciais (diferenças entre a renda arrecadada e o gasto efetuado na província pelo governo central) acusando o governo imperial de explorar as províncias do Norte em benefício das já prósperas províncias do Centro-Sul ou na defesa militar (caso do Rio Grande do Sul). São Paulo, por sua vez, desenvolvia o argumento em favor da riqueza crescente gerada pelo café que não se mantinha na província, expropriada em favor das regiões parasitárias e decadentes do Nordeste", A Questão Fiscal na Transformação Republicana - Continuidade e Descontinuidade, in Economia e Sociedade, Campinas, nº 10, jun. 1998, p. 148. 
unidade provincial desenvolvia ${ }^{343}$. Naquela época, por exemplo, São Paulo desejava obter financiamento para atrair imigrantes que seriam empregados na lavoura, enquanto a Bahia reivindicava dinheiro para transformar os engenhos em usinas e, dessa forma, conseguir manter-se competitiva no mercado açucareiro ${ }^{344}$.

Esse quadro de disparidades foi-se agravando de modo progressivo, na medida em que a Província de São Paulo adquiria predominância no cenário nacional. Com o acúmulo de riquezas por essa unidade provincial, os políticos bandeirantes passaram a questionar insistentemente o centralismo em operação, pois discordavam dos arranjos imperiais que determinavam a transferência das rendas das Províncias mais prósperas para as unidades mais atrasadas e, inclusive, para a própria Corte. Os republicanos ganharam força ao defenderem a tese de que a descentralização seria imprescindível para manter a unidade do país, sendo a autonomia política impostergável elemento de dinamização da economia brasileira $^{345}$.

Sem dúvida, a Província de São Paulo, embora tivesse os mais férvidos defensores do republicanismo federativo, não foi a única que abraçou esse movimento. $O$ descontentamento com a centralização monárquica, em todos os planos da vida pública, era generalizado e, consoante anota WILMA PERES COSTA, a questão fiscal no Império juntamente com as fissuras abertas no Estado unitário com a emancipação dos escravos foram fatores que conferiram, em todo o território nacional, avultada força às aspirações federalistas ${ }^{346}$. Com a superação do sistema escravagista, as Províncias exigiam cada vez mais políticas específicas de trabalho e de imigração, e esse fato desencadeou a formação de demandas regionais divergentes e contraditórias. O cenário político do país transfigurou-se num palco tomado por blocos defensores de interesses multifacetários, onde o consenso, se existia, estava justamente na urgência de neutralização do excessivo centralismo da $\mathrm{Coroa}^{347}$.

\footnotetext{
${ }^{343}$ Em contrário, JoÃo CAMILlO DE OLIVEIRA TORRES defende que, no final do século XIX, não obstante a República e a Federação terem sido trazidas à história do Brasil no momento em que uma nova etapa da história econômica do Brasil era estreada, "do ponto de vista econômico, a situação não se altera muito. Continuávamos agrários e cada Estado, como as capitanias, constituía um compartimento estanque”, Ob. cit., pp. 288-289.

${ }^{344}$ Cf. FÁbio Cirino PeiXoto, Ob. cit., p. 41.

${ }^{345}$ Cf. Idem, ibidem.

${ }^{346}$ Cf. Wilma Peres Costa, Ob. cit., p. 143.

347 Esclarece VICTOR NUNES LEAL que o trabalho servil foi uma das peças essenciais da centralização do poder ao longo do século XIX, haja vista que, caso as províncias fossem dotadas de amplos poderes no tratamento de seus interesses regionais, certamente algumas delas colocariam termo à escravidão, adotando o trabalho livre, o que corresponderia ao esfacelamento da unidade nacional e ao comprometimento da integridade econômica do Estado imperial. De fato, o abandono do escravismo no país significou o golpe de morte do Império, sem, no entanto, trazer fragmentação territorial, em virtude dos arranjos políticos operados
} 
O ponto fulcral da transição do Império para a República radica-se, portanto, na crescente diversificação da base econômica ocorrida a partir de 1870, notadamente, com o florescimento da cafeicultura no oeste paulista e, por consequência, com a heterogeneidade que se aprofundava de modo paulatino entre o Centro-Sul e o Nordeste. A proposta de adoção do federalismo ganhava espaços progressivamente maiores, ao representar uma solução provável à problemática questão da substituição do trabalho servil. Afirmava-se veementemente que deveria competir às unidades federadas cuidar desse assunto conforme os interesses específicos capitaneados por elas, o que seria possível mediante o exercício da autonomia ${ }^{348}$. Assim, o esforço despendido por grande parcela das lideranças provinciais estava calcado no intuito de proteger e de promover interesses econômicos diversificados, os quais se corporificavam em segmentos regionais espalhados por todo o território nacional, desejosos de exercerem efetivamente o denominado autogoverno ${ }^{349}$.

Cumprir a missão de estruturar um Estado federal, como sabido, sempre será tarefa complexa e delicada, pois demanda a conjugação de inúmeras variáveis, cuja interação pode resultar em problemáticos pontos de tensão. Tais situações conflituosas, caso esquecidas, poderão contrapor os entes federados e determinar o esvaziamento da verdadeira essência do federalismo, na medida em que as partes tenderão a cultivar desapego ao propósito de agir em consonância com os postulados da harmonia e da solidariedade. E esse quadro de pouco prestígio aos ideais de colaboração intergovernamental e de respeito mútuo entre os integrantes da Federação é identificado com facilidade no contexto da República Velha, sendo que suas causas repousam grandemente na atuação das oligarquias regionais desejosas de poderes autônomos incontrastáveis.

Essa tessitura, na qual predominava a veemente defesa do regionalismo cambiante das elites econômicas e políticas, impediu a institucionalização de arranjos jurídicos projetados para compensar com eficiência as disparidades regionais altamente impactantes na sedimentação do ideário federalista no Brasil. Tais ferramentas nem chegaram a ser pensadas nos anos iniciais da República, pois os fatores históricos narrados brevemente,

no momento de criação e de consolidação do republicanismo brasileiro, Cf. Coronelismo, Enxada e Voto, $5^{\mathrm{a}}$ ed., São Paulo, Alfa-Omega, 1986, pp. 79-80.

${ }^{348}$ Cf. Wilma Peres Costa, Ob. cit., p. 142.

${ }^{349}$ Sufraga essa conclusão JOSÉ MURILO DE CARVALHO, ao anotar que, "para a maioria dos federalistas, este sistema de organização política se identificava com o provincialismo; isto é, com o autogoverno provincial, sem o menor interesse na participação política ou nos direitos provinciais. No caso dos republicanos de São Paulo e de outras províncias, o federalismo não era outra coisa senão o desejo das elites econômicas e políticas de governarem a si mesmas”, El Federalismo Brasileño: Perspectiva Historica, in ¿Hacia um Nuevo Federalismo?, Alicia Hernández Chávez (coord.), México, Fondo de Cultura, 1996, p. 40. 
bem como as bases sociais e econômicas em que a Federação se assentou e se desenvolveu, determinaram a soldagem e a modelação de laços associativos que colocavam os entes estaduais em sensível distanciamento em relação à União. Foi desse modo que o denominado federalismo dual, fortemente inspirado na matriz estadunidense, ditou a sistemática de funcionamento do regime federativo nacional por período considerável de nossa história ${ }^{350}$.

A compreensão das principais circunstâncias e forças envolvidas na etapa de implantação do federalismo no Brasil mostra-se peça indispensável para a análise e o entendimento da atual situação enfrentada pelos entes autônomos nacionais. As severas clivagens territoriais e o desinteresse das partes em criar mecanismos consistentes e solidários de relacionamentos recíprocos podem ser identificados já no nascedouro da Federação nacional, e, como não poderia deixar de ser, tais características iniciais persistiram ao longo de toda nossa experiência federativa.

Nesse sentido, FERNANDO LUIZ ABRUCiO enfatiza que o surgimento da estrutura federativa no Brasil também não conseguiu estabelecer uma relação de interdependência entre a União e os Estados, pois havia um enorme desequilíbrio federativo que contrapunha, de um lado, dois Estados muito fortes - Minas Gerais e, de forma destacada, São Paulo - contra a autoridade nacional frágil frente a eles, e, noutra banda, mais de uma dezena de unidades estaduais incapacitadas de sobreviverem por conta própria ${ }^{351}$.

O aludido quadro denotava inegável dificuldade de estruturar-se um autêntico regime federativo no Brasil, uma vez que a autonomia política era mera declaração constitucional, inexistindo, em termos práticos, para quase a totalidade dos Estadosmembros, os quais dependiam com frequência do auxílio do Tesouro federal. Ademais, recorrer à ajuda da União, durante a vigência da República Velha, significava acatar automaticamente os interesses manifestados por aqueles dois Estados que exerciam

\footnotetext{
${ }^{350}$ MANOEl GonçAlves FerReira Filho esclarece que, no processo de elaboração do Estado federal brasileiro, "sem dúvida, foi a Federação americana o modelo seguido. Era este certamente o que mais próximo estava de nossas condições. Esta inspiração claramente se manifesta pela consagração da igualdade absoluta entre Estados-membros, de que resulta a simetria na representação do Senado, nas competências, na repartição das fontes tributárias, bem como pela rigorosa separação das esferas, da União, de um lado, dos Estados, de outro, como é típico do federalismo dualista então consagrado na América do Norte", Aspectos do Direito Constitucional Contemporâneo, São Paulo, Saraiva, 2003, p. 174. Anote-se ainda que esse entendimento, no tocante à influência do modelo dualista de Estado federal na Constituição brasileira de 1891, é confirmado, entre outros, por FERnANDA DiAs MENEZES DE AlmeIDA, Competências na Constituição de 1988, Ob. cit., p. 27; RAul Machado HoRTA, Tendências Atuais da Federação Brasileira, Ob. cit., pp. 7-8; José Luiz de Anhaia Mello, O Estado Federal e suas Novas Perspectivas, São Paulo, Max Limonad, 1960, p. 138; NINA RANIERI, Sobre o Federalismo e o Estado Federal, Ob. cit., p. 96; JANICE Helena Ferreri, A Federação, in Por uma Nova Federação, Celso Bastos (coord.), Ob. cit., pp. 28-29; Luis Roberto Barroso, Ob. cit., pp. 33-34; e AlesSANDra Silveira, Ob. cit., pp. 51-64.

${ }^{351}$ Cf. Os Barões da Federação: Os Governadores e a Redemocratização Brasileira, Ob. cit., p. 40.
} 
domínio na política do país, num sistema que ficou conhecido como o "bloco café com leite", por meio do qual as lideranças paulistas e mineiras compartilharam o controle da União. Foi nesse ambiente que, em reiteradas oportunidades, o artifício da simetria foi utilizado para justificar a viabilidade de um sistema federativo antagônico à diversidade, $\mathrm{o}$ qual congregou unidades tão diversificadas e carentes de atenções especiais ${ }^{352}$.

Nesse compasso, entende-se que militar em favor da busca de instrumentos jurídicos voltados a corrigir essas assimetrias fáticas e relacionais impregnadas no bojo de nosso Estado federal representa uma tentativa de resgatar um débito nunca saldado satisfatoriamente pelos construtores do país. Trata-se da dívida de proporcionar ao federalismo brasileiro um pacto voltado a ordenar - ou, ao menos, verdadeiramente intencionado em estabelecer - um regime no qual o dever de respeito às nossas diversidades regionais seja a tônica primeira a ditar o funcionamento das instituições estatais ligadas à descentralização espacial do poder político.

É certo ainda que esse sistema desejado passe a admitir os desníveis regionais não como barreiras à formulação de ações concertadas entre o poder central e os demais entes autônomos, mas entendendo-os como um constante estímulo ao aperfeiçoamento dos laços associativos de cooperação intergovernamental. Caberá, como já é possível deduzir, a um processo de reestruturação das bases da Federação brasileira garantir o atendimento dessa proposta. Nessa empreitada, é imprescindível considerar a conveniência de adoção no país das ferramentas vinculadas à teoria do federalismo assimétrico para, atendo-se ao arcabouço histórico, econômico e social fundido ao Estado brasileiro, contribuir para o fortalecimento de nosso pacto federativo.

O esperado é, em síntese, que ocorra a progressiva eliminação das consequências derivadas da manipulação do cenário político por lideranças regionais refratárias ao desenvolvimento regional e econômico integrado. Tal fato, não é de hoje, prejudica em muito os entes federados que dispõem de pouca ou nenhuma influência no contexto nacional, precisamente aqueles que deveriam encontrar na Constituição, em vez de conformismo institucional, efetivos mecanismos de superação desse quadro dramático.

352 Cf. Fernando LuIZ Abrucio, Os Barões da Federação: Os Governadores e a Redemocratização Brasileira, Ob. cit., 40. 


\section{IV.1.1. Os Albores do Estado Federal Brasileiro: O Coronelismo e a Perpetuação das Desigualdades Regionais}

No Brasil, diferentemente dos fatos desenrolados nos Estados Unidos, onde os Estados-partes tiveram de ratificar, mediante referendo, os termos estabelecidos na Convenção de Filadélfia de $1787^{353}$, durante o processo de instauração do federalismo, nenhuma aprovação foi necessária pelas antigas Províncias transformadas abruptamente em Estados pelo Decreto $n^{\circ} 1$, de 15 de novembro de 1889. Foi esse rápido e superficial evento político-institucional que dispensou a participação dos entes que passariam a formar o Estado composto brasileiro, o principal fator que levou Jỗo CAMILlO DE OLIVEIRA TORRES a anunciar ter sido o federalismo previsto na Constituição Republicana de 1891 um conceito revestido de caráter meramente jurídico-formal, porque resultante do arbítrio do legislador e inapropriado para cuidar dos interesses nacionais em sua integridade ${ }^{354}$.

De acordo com essa concepção, o Estado federal no Brasil significou não mais do que um engenho jurídico para acolher o status quo constituído pelas oligarquias regionais e provinciais poderosas desde o Império. Na confecção de nosso primeiro pacto federativo, deixaram de ser contabilizados todos os fatores de natureza fática que, se fossem devidamente equacionados, garantiriam o acerto do esquema de descentralização política trazida pelo texto constitucional ${ }^{355}$. Com efeito, esse distanciamento inicial da realidade econômica e social trouxe à Federação consequências ainda sentidas na atualidade, sobretudo em relação à modelação de nosso esquema de descentralização política.

Errou-se gravemente ao aceitar a crença insustentável - e ainda hoje cultuada - de que a simples positivação de normas jurídicas seria suficiente para transformar o plano da realidade, no qual tais comandos legais deverão incidir. De fato, como é sabido e razoável sustentar, o Direito deve conformar-se aos contextos nos quais é empregado, permitindo gradativamente que a solução de problemas possibilite a obtenção de ganhos e de conquistas impossíveis de serem alcançados antes, se não fosse o manuseio de institutos jurídicos. O federalismo, porque é uma forma de Estado altamente dependente dos

\footnotetext{
353 Cf. Benjamin Fletcher Wright, Introdução do Editor, ora in O Federalista, Ob. cit., pp. 11-17; e Augusto Zimmermann, Ob. cit., p. 249.

${ }^{354}$ Cf. $O$ b. cit., p. 46. Acerca das diferenças verificadas nas etapas de advento e de afirmação institucional do Estado federal brasileiro e da Federação estadunidense, consultar também FERnANDO LuIZ ABRUCIO e Valeriano Mendes Ferreira Costa, Reforma do Estado e o Contexto Federativo Brasileiro, São Paulo, Fundação Konrad-Adenauer-Stiftung, 1999, pp. 32-34.

${ }^{355}$ Cf. Francisco de Oliveira, A Crise da Federação: da Oligarquia à Globalização, in A Federação em Perspectiva: Ensaios Selecionados, Rui de Brito Álvares Affonso e Pedro Luiz Barros Silva (org.), São Paulo, FUNDAP, 1995, p. 77.
} 
desenhos jurídicos efetuados na Carta Constitucional, deve seguir estritamente essa orientação.

Ao se tomar por base o processo político que resultou no Estado federal e, em especial, o modo como nossos incipientes laços associativos foram amarrados, vislumbrase que, à época, ainda que os Estados-membros discordassem do projeto de Federação idealizado pela constituinte da Primeira República, nada poderia ter sido feito por eles. Essa constatação é justificada no fato de que, naquele período, não existia no país uma forte ligação entre o regime federativo e os vetores do republicanismo.

Embora, como visto, no final dos anos imperiais, tenham os republicanos enaltecido o estandarte da descentralização política mediante a técnica do federalismo, esse dado retrata apenas uma aparente campanha em favor da democratização do poder. No Estado federal que fora inicialmente arquitetado, o que se assistiu foi ao reino das oligarquias, do patrimonialismo e da ausência do povo no horizonte político ${ }^{356}$. Na origem de nossa Federação, foram reiteradas as negativas do postulado assinalado por INOCÊNCIO MÁRTIRES CoElho de que, entre os traços característicos do republicanismo, está necessariamente o reconhecimento de corpos territoriais autônomos que podem ser traduzidos no próprio princípio federativo, assim como o experimentado pelos Estados Unidos $^{357}$.

Os múltiplos e tendenciosos acordos políticos realizados pelas elites regionais no alvorecer da República determinaram o aparecimento de outra consequência inquietante e prejudicial ao desenvolvimento do Estado federal brasileiro: a perpetuação da desigualdade territorial entre as diferentes regiões. Tal fato encontra ressonância na circunstância de que, nos primeiros anos de aplicação da Constituição elaborada, a eficiência governamental foi alçada à condição de diretriz cardeal da implantação do federalismo, e isso acabou abrindo caminho para que as oligarquias enxergassem na alardeada autonomia política, o elemento garantidor do exercício livre e desimpedido de suas atividades e pretensões econômicas e localistas.

Desprezou-se, pois, a amplitude da questão de que o crucial naquele momento seria encontrar, na forma de Estado, mecanismos para assegurar a todos os entes federados condições reais de autogoverno, e não transmutá-la em ferramenta para a defesa de interesses econômicos segmentários, como aconteceu. Perdeu o constituinte revolucionário

356 Cf. Fernando LuIz ABRuCio, Os Barões da Federação: Os Governadores e a Redemocratização Brasileira, Ob. cit., p. 40.

${ }^{357}$ Cf. Fundamentos do Estado Brasileiro, in Curso de Direito Constitucional, Gilmar Ferreira Mendes, Inocêncio Mártires Coelho e Paulo Gustavo Gonet Branco, Ob. cit., p. 170. 
a oportunidade de, com o advento dessa nova forma de organização do poder territorial no Brasil, imprimir salutar função promocional às estruturas de descentralização do poder. Desde o início, a Federação brasileira não figurou como estrutura apta a proporcionar o desenvolvimento do país como um todo, nem tampouco conseguiu o regime federativo atender às unidades autônomas de modo igualitário, de modo a assegurar a todas as regiões os cuidados precisos para assegurar o respeito à diversidade sempre marcante.

A premissa de que as partes do Estado federal gozavam de idêntico nível de desenvolvimento foi equivocadamente adotada e, assim, a todas foram distribuídas a mesma parcela de poder, de competências e de tributos. Não se computaram, sob nenhum quadrante, os desníveis relativos à população, ao território e à riqueza de cada componente que passaria a integrar a estrutura federal do Estado. O ímpeto autonomista dos republicanos, ao ter admitido que o Estado federal seria, precipuamente, um sistema funcional de governabilidade, fez com que fosse desconsidera a relevante situação de que os integrantes estaduais do pacto federativo estavam em níveis assimétricos de desenvolvimento no momento em que esse pacto foi institucionalizado ${ }^{358}$.

No que respeita exclusivamente à dimensão fiscal cimentada na Carta Política de 1891, deve-se observar que essa patente diferenciação fática observada entre os Estados que integravam o concerto federativo também teve profundos reflexos na operacionalização do sistema tributário elaborado pelo constituinte de então ${ }^{359}$. O difícil trabalho de equacionar a grande diversidade econômica regional que tomava o país no século XIX foi colocado à Assembleia Constituinte, instalada após a decomposição do Império, e, embora fosse conhecida a existência de Estados extremamente desiguais no aspecto de desenvolvimento econômico (representando isso, consequentemente, desigual potencialidade de produção de recursos fiscais), a estrutura de tributação vencedora não considerou esse importante aspecto.

Tal qual será apontado, o conjunto de normas tributárias apresentado pela primeira Constituição republicana era inabilitado a resguardar e a promover os multifacetários estágios de desenvolvimento verificados entre as diversas partes do território nacional. $\mathrm{Na}$ mesma direção, os arranjos praticados no âmbito da Assembleia Constituinte evidenciavam

\footnotetext{
${ }^{358}$ JoÃo CAMILLO DE OLIVEIRA TORRES registra que, após o estabelecimento do regime federativo no país, "aconteceu um fato muito simples: nem todos os Estados se encontravam em condições de conseguir semelhante resultado. Eis tudo. O federalismo teve de enfrentar a situação clássica de liberalismo: igualdade de oportunidades para pessoas desigualmente dotadas representa, no fim, o coroamento das desigualdades. $\mathrm{O}$ fato é que se umas províncias se beneficiariam da autonomia - e ninguém poderá afirmar se, de um ou outro modo, estas províncias realizariam, ou não, a mesma aventura" (Ob. cit., p. 184).

${ }^{359}$ Cf. Wilma Peres Costa, Ob. cit., p. 158.
} 
nítido beneficiamento de alguns setores da economia brasileira da época, notadamente aqueles campos econômicos explorados pelas elites que despontavam na condução da vida política do país. Daí porque DALMO DE ABREU DALlARI conclui que "os desajustes econômicos e financeiros - primeiro das Províncias e, depois, dos Estados - foram causa e consequência das mais significativas, do desequilíbrio político que acompanha a introdução da República no Brasil e que até hoje não foi superado"360.

Com efeito, as finanças públicas estaduais, ancoradas em tributos cuja competência foi exclusivamente atribuída a esses entes pelo art. $9^{\circ}$ da Lei Fundamental da Primeira República $^{361}$, estavam fundadas essencialmente na exportação, o que retratava a própria característica primário-exportadora da economia do país. Esse fato deflagrou, após 1891, a reiteração da desigualdade regional, pois o projeto de discriminação de rendas vitorioso na Constituinte trouxe ganhos basicamente aos Estados-membros que possuíam um destacado comércio com o exterior, tal qual era a situação de São Paulo, Minas Gerais, Rio de Janeiro, Bahia, Pará e Amazonas. Ao menos na República Velha, fica comprovado que o conceito de autonomia financeira serviu para atender somente os desígnios daqueles Estados mais ricos - em particular, São Paulo -, o que evidencia o caráter originalmente hierárquico-econômico da Federação brasileira ${ }^{362}$.

Esses descuidos resultaram numa aceleração do desenvolvimento econômico-social de algumas unidades federadas, na medida em que estas lograram êxito em auferir receitas bastantes para desempenhar suas competências (e, com isso, manter um nível adequado de serviços públicos), enquanto outras sofreram duro revés em seu crescimento em razão da crônica carência de recursos financeiros ${ }^{363}$. O artificialismo jurídico estabelecido pela fórmula político-constitucional do sistema federativo consignado na Lei Republicana de

\footnotetext{
${ }^{360}$ Cf. Os Estados na Federação Brasileira, de 1891 a 1937, in Revista de Direito Constitucional e Ciência Política, ano 2, no 3, jul. 1984, p. 113.

361 “Art. $9^{\circ}$ - É da competência exclusiva dos Estados decretar impostos:

$1^{\circ}$ ) sobre a exportação de mercadorias de sua própria produção;

$2^{\circ}$ ) sobre imóveis rurais e urbanos;

$3^{\text {o) }}$ sobre transmissão de propriedade;

$4^{\circ}$ ) sobre indústrias e profissões.

$\S 1^{\circ}$ - Também compete exclusivamente aos Estados decretar:

$1^{\circ}$ ) taxas de selos quanto aos atos emanados de seus respectivos Governos e negócios de sua economia;

$\left.2^{\circ}\right)$ contribuições concernentes aos seus telégrafos e correios".

${ }^{362}$ Cf. Fernando LuIZ Abrucio, Os Barões da Federação: Os Governadores e a Redemocratização Brasileira, Ob. cit., p. 33. No mesmo sentido: JoÃo PANDí́ CAlOGERAS, Formação Histórica do Brasil, Rio de Janeiro, Pimenta de Mello, 1930, p. 415; e CezAR SAldanha SouzA Junior, Consenso e Constitucionalismo no Brasil, Ob. cit., 2002, pp. 86-91.

${ }^{363}$ Cf. Manoel Gonçalves Ferreira Filho, Aspectos do Direito Constitucional Contemporâneo, Ob. cit., pp. $173-175$.
} 
1891 agravou em demasia as diversidades regionais e demonstrou o desacerto do constituinte em tratar as diferenças que reinavam no território nacional ${ }^{364}$.

Em complemento a essa conclusão, há o convencimento de RAYMUNDO FAORO sobre a aplicação concreta do texto constitucional da Primeira República. Entende ele que, em aspectos práticos, a obra dos republicanos não diferiu muito da Carta Imperial, uma vez que, durante os anos nos quais vigorou, as ficções jurídicas acabaram assumindo o caráter de um disfarce, para que, à sombra da legitimidade simulada, determinadas forças políticas e sociais (as oligarquias regionais) pudessem impor seus interesses, sem observar os mandamentos constitucionais impressos ${ }^{365}$. Nesse mesmo sentido, RAUL MACHADO HORTA afirma ainda que "o período inaugural do federalismo brasileiro, que obedeceu ao comando normativo da Constituição Federal de 1891, reflete a presença de contrastes, denunciando conflitos entre a norma constitucional e realidade social" 366 .

Do cotejo entre as previsões jurídicas do texto constitucional e as fortes determinantes da realidade, é indubitável a vitória destas, uma vez que as forças sociais, por não estarem acomodadas de forma devida pelo constituinte, conseguiram sem muito custo subverter os comandos normativos agasalhados na Lei Maior. Apesar de trágica, essa constatação custou a ser questionada, sobretudo porque, à época, as elites que dirigiam os rumos do cenário político brasileiro eram as mesmas que se encarregavam repetidamente de descumprir os preceitos constitucionais. Os laços federativos firmados com o advento da República, em verdade, não foram pensados para cuidar dos rigorosos contrastes existentes e, ao que parece, essa falta de atenção, observada na gênese do federalismo nacional, contaminou, em algum grau, o ideário de todos os subsequentes constituintes.

Resta claro, portanto, que a circunstância de alguns poucos Estados-membros terem estendido sua influência para áreas que ultrapassavam seus respectivos limites geográficos

\footnotetext{
${ }^{364}$ Uma significativa anotação histórica merece ser feita neste ponto: em confirmação da tese de que a política tributária está na base do ideal federativo brasileiro, constata-se que, em 1870, ano da primeira publicação da obra A Província, AURELIANO CÂNDIDO TAVARES BASTOS vislumbrou a urgência do emprego da descentralização política como ferramenta habilitada a proporcionar desenvolvimento das regiões por meio da aplicação de receitas geradas pelos próprios territórios, abandonando-se a prática de concentrar no poder imperial a arrecadação tributária. Esse expressivo autor para a história de nosso Estado federal assim considerou: "Não se há de acelerar o progresso das Províncias e municípios, não hão de as localidades empreenderem grandes melhoramentos sem que, antes de tudo, a centralização dominante ceda o lugar que usurpou o fecundo princípio da reforma constitucional de 1834. Então, exercendo amplamente o governo dos seus interesses, as Províncias aceitariam sem repugnância os ônus inerentes. Mas, privá-las da administração independente e pretender sujeitá-las a maiores e crescentes impostos, aliás sem aplicação às suas necessidades imediatas, é política que mais e mais tornar-se-á impopular no Brasil”, Cf. Ob. cit., pp. 205-206. ${ }^{365}$ Cf. Ob. cit., p. 533. Posicionamento parecido é tomado por CÁRMEN LúCIA ANTUNES Rocha, Ob. cit., pp. 226-227.

${ }^{366}$ Tendências do Federalismo Brasileiro, in Revista Forense Comemorativa - 100 anos, v. 1, Ob. cit., p. 483.
} 
retrata a frágil condição dos laços federalistas definidos nos primeiros anos do republicanismo. Esse relevante fato confirma um aspecto proeminente durante toda a existência da Federação brasileira: o de que, apesar de a Constituição sempre preceituar a igualdade jurídica entre os entes federados, essas unidades, na prática, desde os momentos preparatórios da adoção dessa forma de Estado, nunca foram - e ainda não são - assim consideradas pelas instituições nacionais.

A autonomia política, toda vez dividida em idênticas proporções entre os Estados (e, na presente ordem constitucional, também entre os Municípios), quando exercitada, transforma-se em multifacetárias formas de materialização. Esse dado óbvio, consubstanciado em um sem-número de concretizações de governos subnacionais, não seria em nada problemático (ao contrário, representa corolário lógico da Federação) se não fossem os impactos derivados de algumas disparidades que surgem a partir da manipulação dos instrumentos governamentais em contextos altamente heterogêneos, como o Brasil. A gravidade que atormenta reside, em essência, na apuração de que a União, em diversos episódios, influenciada pelas elites políticas regionais, chancela - e, às vezes, até propicia - a intensificação de desigualdades prejudiciais ao pacto federativo.

E, como o curso histórico e as demais variantes relacionadas com a configuração do ambiente social se fundem para influenciar o Estado federal, na evolução do federalismo brasileiro, identifica-se que essa característica conseguiu assumir inconstantes modos de manifestação. Da "Política dos Governadores", na República Velha, às distorções e aos impasses que atualmente dificultam a execução de políticas públicas que congreguem vários entes, muitos foram os episódios em que a insistência na negativa, por parte do constituinte, do caráter assimétrico da Federação resultou em experiências complicadoras da coesão do país.

Diante de um complexo quadro natural, econômico e político, em que a excessiva desigualdade requer soluções particularizantes em face das cambiantes realidades que precisam ser disciplinadas, a consolidação de um projeto consistente de descentralização político-territorial do poder atesta a pertinência de se introduzirem mecanismos nãoconvencionais de acomodação dessas disparidades. Daí o porquê de a teoria do federalismo assimétrico precisar, autenticamente, ser observada pelas instituições e órgãos de governo responsáveis pelo funcionamento do Estado nacional. Insistir no desprezo das desigualdades que há entre as unidades federadas alocadas no mesmo nível de governo certamente representa a abertura de caminhos para que capítulos de nossa história, que não 
tiveram melhor sorte, possam se repetir, tal qual aconteceu, por exemplo, com a "Política dos Governadores" a ser analisada na sequência.

\section{IV.1.2. A Hierarquização dos Entes Federativos: A "Política dos Governadores" na Primeira República}

Mesmo inadequada para ordenar o contexto no qual foi elaborada, a Carta Republicana de 1891, ao instaurar o regime federativo, possibilitou a divisão de competências entre a União e os Estados-membros. Trouxe ainda um esquema de partilha de rendas entre os diversos entes federados e tratou, como era esperado, de reservar às unidades estaduais inúmeros poderes. O sucesso no fracionamento do poder político, agraciando-se os entes subnacionais com a pretendida autonomia, não impediu, no entanto, que se atingissem verdadeiramente os objetivos de democratização e de distribuição efetiva do poder.

Peculiaridades históricas e políticas do Brasil foram decisivas para fazer com que nossa Federação tomasse rumos muito diferentes daqueles trilhados pela matriz estadunidense, admitida aqui como paradigma inspirador pelos republicanos. O Estado federal, introduzido no país no final do século XIX, conforme observa PINTO FERREIRA, teve como característica inaugural o "exagero do estadualismo, porque no fundo a política brasileira de então foi a política dominante nos grandes Estados da Federação brasileira, especialmente São Paulo e Minas Gerais, os dois Estados mais fortes da Federação"

Os políticos paulistas - da mesma forma que outras lideranças estaduais beneficiadas pelo desenvolvimento de suas respectivas economias regionais - adquiriram a desejada autonomia, atributo que, a despeito de ter facilitado a implantação da República, teve também consequências negativas. Dentre os comprometedores reflexos apurados, está a primazia assumida por algumas poucas oligarquias estaduais, que, por meio do estabelecimento de acordos políticos, conseguiram ultrapassar o domínio sobre os órgãos estaduais de poder, passando a controlar também a União.

Houve, nos anos imediatamente seguintes ao da fundação do Estado federal, visível sobrevalorização do emprego do ideal autonomista pelos entes subnacionais daquela

\footnotetext{
${ }^{367}$ Curso de Direito Constitucional, Ob. cit., p. 270. Acerca do predomínio de determinados Estados na condução da política nacional nos primeiros anos da República Velha, consultar também estudo desenvolvido por Márcia Miranda SoARes, Teoria do Sistema Federal: Heterogeneidades Territoriais, Democracia e Instituições Políticas, Dissertação de Mestrado, Faculdade de Filosofia e Ciências Humanas da UFMG, 1997, pp. 100-118.
} 
época. Os governos estaduais, originados a partir das delimitações geográficas das antigas Províncias, procuraram agir com a máxima independência, sem qualquer espécie de consideração pelos interesses de seus congêneres e, em algumas situações, ignorando por completo os interesses da própria Federação ${ }^{368}$.

A respeito, observa CÁRMEn LÚCIA ANTUNES RoCHA que "os primeiros momentos da experiência federativa brasileira não satisfizeram às expectativas quer dos mais radicais, quer dos mais moderados defensores da implantação dessa forma de Estado no país. Os Estados-membros, ofuscados, talvez, pelo súbito encontro de uma independência antes inexistente, romperam a sorver da Constituição os poderes que lhes eram assegurados e mais alguns que o não eram, em comportamento político que contribuiu para isolá-los mais ainda uns dos outros, tornando-se mais difícil a experiência federativa"369.

Observa-se, pois, que, desde sua gênese, a Federação brasileira não teve como diretiva o compromisso de alcançar a unidade nacional mediante o encontro de vontades entre os entes que a integravam, preservando-se, ao mesmo tempo, as potencialidades inerentes a cada uma das regiões ${ }^{370}$. Ao contrário, as Províncias uniram-se porque suas lideranças eram crédulas em um projeto federalista promitente de ampla autonomia política, sobretudo porque os liberais haviam difundido a ideia de que a eliminação do controle hipertrofiado do poder monárquico traria, como consequência, a equalização dos benefícios a todas as unidades, indistintamente.

Segundo o propugnado, esse progresso iria acontecer de forma natural, pois seria um efeito inarredável da liberdade decisória que os Estados passariam a ter. Acreditava-se, dessa maneira, que, a partir do momento em que os entes federados pudessem resolver autonomamente os assuntos de seu interesse, eles iriam alcançar, sozinhos e mediante esforços próprios, o contínuo e desejado desenvolvimento ${ }^{371}$. Foi nessa toada que a autonomia outorgada aos entes federados acabou sendo aproveitada apenas por alguns dos

\footnotetext{
${ }^{368}$ Cf. Dalmo de Abreu Dallari, Os Estados na Federação Brasileira, de 1891 a 1937, Ob. cit., pp. 100101.

369 Ob. cit., p. 218.

${ }^{370}$ Uma leitura conforme a perspectiva estabelecida em $O$ Federalista, demonstra-se ser possível a identificação das unidades federativas durante a vigência da Primeira República como sendo a materialização do que MADISON denominava facção ("grupo de cidadãos, representando quer a maioria, quer a minoria do conjunto, unidos e agindo sob um impulso comum de sentimentos ou de interesses contrários aos direitos dos outros cidadãos ou aos interesses permanentes e coletivos da comunidades", Ob. cit., p. 148). Entretanto, ao menos no período inicial de nosso Estado federal, a União, na contramão do que fora idealizado por HAMILTON, MADISON e JAY, não obteve o êxito esperado em matéria de coordenação dos diferentes interesses que se chocavam no campo da política nacional.

371 Cf. Fernando Luiz Abrucio, Os Barões da Federação: Os Governadores e a Redemocratização Brasileira, Ob. cit., p. 33.
} 
Executivos estaduais, os quais representavam a expressão oligárquica de um poder que se revestia de um simulacro constitucional, sobretudo porque baseado na força do coronelato.

Não é novidade que o federalismo precisa levar em conta os substratos social e econômico dos territórios em que será instituído. Tal recomendação é ainda mais importante, segundo MANOEL GonÇALVES FERREIRA FILHO, para as Federações que se formaram pelo processo de segregação (como ocorreu com o Brasil), haja vista que nessas geralmente existem diferentes ritmos de desenvolvimento entre as regiões integradas ${ }^{372}$. Essa identificação de velocidades variadas entre os Estados deve ser admitida como desigualdades entre elas, o que passa a exigir tratamento no plano da Constituição que irá ser a base jurídica do Estado federal.

Como assinalado, a orientação principiológica que estabelece absoluta paridade entre os entes federados traz complicadas consequências à governabilidade de muitos Estados federais. O cerne do problema está no fato de que, não basta atribuir o mesmo grau de autonomia às unidades, delegando-se idênticas competências e os mesmos tributos aos atores do conjunto federativo, uma vez que a realidade, implacavelmente, desmistifica essa prática constitucional. Os rumos percorridos pelos diversos entes demonstram o quão heterogêneas são as partes federadas, tendo em vista que uma gama de circunstâncias fáticas influenciam o exercício das prerrogativas atribuídas a essas peças.

Foi exatamente pelo fato de negligenciar essas circunstâncias e grandezas na formulação de nossa primeira Constituição republicana que ocorreu o agravamento dos desníveis territoriais entre os Estados. Não havia razões para aplicar aqui, numa Federação advinda de um processo de segregação, o princípio da isonomia entre os entes federados, uma vez que essa diferença de gênese é, por si só, suficiente para atestar a impertinência da reprodução pelo constituinte brasileiro dos mesmos institutos informadores do federalismo estadunidense. Averbe-se ainda que, durante a Convenção de Filadélfia, a diretriz da

\footnotetext{
372 Cf. Constituição e Governabilidade: Ensaio sobre a (In)governabilidade Brasileira, Ob. cit., p. 55. Convalida esse posicionamento ROBERT AGRANOFF, ao observar que existe maior facilidade de se introduzir mecanismos jurídicos de assimetria naqueles Estados federais originados a partir de processos territoriais segregatórios. Assim estatui o autor: “[...] em muitas Federações, destacadamente aquelas criadas pela agregação de unidades políticas anteriormente existentes, as bases históricas e as tradições dos Estadosmembro estão profundamente arraigadas às respectivas partes, e isso resulta diretamente em assimetria populacional, territorial e de riquezas, aspectos insuscetíveis de ajustamento por meio de alterações constitucionais em suas respectivas áreas limítrofes. No entanto, em outros Estados federais, notadamente os originados a partir de processos de segregação territorial, têm sido realizados esforços para ajustar o número, o tamanho e os limites fronteiriços das unidades federadas criadas, de forma a modelar os níveis de assimetria entre partes do conjunto", Power Shifts, Diversity and Asymmetry, in Accommodating Diversity: Asymmetry in Federal States, Ob. cit., p. 36. Ainda no mesmo sentido, DircÊo Torrecillas RAMOS, $O$ Federalismo Assimétrico, Ob. cit., pp. 72-73.
} 
iguldade formal somente foi acatada para como recurso facilitador da aceitação, por parte dos Estados mais atrasados da América do Norte, das instituições federais ${ }^{373}$.

Uma repartição de competências estabelecida de forma inflexivelmente padronizada, conjugada com uma divisão de rendas também insensível às particularidades regionais, será apenas uma distribuição de prerrogativas e de benefícios, jamais um compromisso razoável de governabilidade. Construções estruturais pautadas na mera descentralização política, e que desconsideram a importância de possibilitar a concretização efetiva da autonomia federativa, podem criar um preocupante círculo vicioso. Na prática, tende a ocorrer a desestabilização do concerto federativo, uma vez que, onde inexistem riquezas, obviamente, os tributos não rendem (ou rendem pouco), e, assim, faltarão meios para que os entes autônomos possam exercer, em níveis adequados de eficiência, as competências que lhe foram confiadas pela Lei Maior ${ }^{374}$.

Esse quadro tende a agravar as desigualdades regionais, e, em situações extremas, ocasionam o surgimento de conflitos ameaçadores para a Federação e para a integridade do país, a exemplo do período compreendido entre os anos de 1891 a 1934. Na constância do lapso temporal referido, os muitos desníveis fáticos que diferenciavam os entes federados brasileiros não foram computados na formulação na repartição de competências e pelos esquemas de divisão de rendas entre os Estados-membros. Esse dado não demorou para fazer com que as unidades autonômas mais poderosas empreendessem coligações entre si para fazer frente à fraqueza demonstrada pela União.

Quando isso aconteceu, tomou forma no país a célebre "Política dos Governadores", consubstanciada no sistema "café com leite", que instalou, no universo da política nacional, primazia exclusiva ao eixo Minas-São Paulo na definição do cargo de Presidente da República. Durante esse capítulo da República Velha, acordos políticos permanentes asseguravam que as eleições dos sucessivos Presidentes da República fossem uma escolha fechada, produto das transações de cúpula sempre envolvendo as mencionadas elites políticas regionais ${ }^{375}$. Os impactos desse período não apenas atingiram os Estados excluídos das alianças, pois, na verdade, a grande prejudicada foi a própria Federação, especialmente porque a União, ente autônomo encarregado de tutelar os

\footnotetext{
${ }^{373}$ Cf. Manoel Gonçalves Ferreira Filho, A Democracia Possível, Ob. cit., p. 111.

374 Cf. MANOEl GONÇAlves FerReIRA Filho, Constituição e Governabilidade: Ensaio sobre a (In)governabilidade Brasileira, Ob. cit., p. 55.

375 A respeito desse tema, recomenda-se a consulta a PAUlo Bonavides, A Constituição Aberta: Temas Políticos e Constitucionais da Atualidade, com ênfase no Federalismo das Regióes, Ob. cit., pp. 395-396.
} 
interesses nacionais, ficou refém da vontade das lideranças políticas de algumas poucas regiões do país.

A prática de revezamento na indicação do Chefe do Executivo federal pelos dois entes federados em questão perdurou vários anos. Tal fator desencadeou o predomínio desses mesmos Estados-membros na tomada de decisões por parte do poder central, notadamente porque passaram eles a ditar, com preponderância, os rumos da vida política do país, trazendo com isso lamentáveis repercussões no já desequilibrado pacto federativo engendrado. Os reflexos negativos dessa sistemática foram tamanhos a ponto de generalizar-se o sentimento de que a República federativa, antes uma conquista de quase todos, acabara tornando-se, paradoxalmente, a vitória de quase ninguém ${ }^{376}$.

\section{IV.1.3. A Constituição de 1934 e a Institucionalização do Federalismo Cooperativo: A Incipiente Compreensão de que as Desigualdades Regionais Constituía um Problema de Estado}

Depois da Primeira Guerra Mundial, os choques verificados no Brasil entre as oligarquias estaduais, somados à forte crise econômica que se iniciou com a quebra da Bolsa de Valores de Nova Iorque, em 1929, causaram, segundo observa GILBERTO BERCOVICI, a queda do regime que vigorava desde a promulgação da Constituição de $1891^{377}$. Assistiu-se à instalação da Assembleia Constituinte de 1933, sendo que havia (ao menos nominalmente) um consenso em torno da manutenção do federalismo no país. Os constituintes de então elaboraram uma nova roupagem aos mecanismos caracterizadores do Estado federal, o que determinou outra feição à Federação brasileira, a qual foi chamada de federalismo cooperativo ${ }^{378}$.

Imbuída da missão de conferir concretude ao federalismo cooperativo, a Carta Política de 1934 estatuía, em seu art. 9, ser “facultado à União e aos Estados celebrar acordos para a melhor coordenação e desenvolvimento dos respectivos serviços, e, especialmente, para a uniformização de leis, regras ou práticas, arrecadação de impostos,

\footnotetext{
${ }^{376}$ Cf. FÁbio Cirino PeiXoto, Ob. cit., pp. 7-8.

${ }^{377}$ Cf. Dilemas do Estado Federal Brasileiro, Ob. cit., pp. 38-39.

378 Ensina RAUL MACHADO HORTA que "a Constituição Federal de 16.7.1934, que se vincula ao difuso ideário político da Revolução de 1930, inaugurou a segunda República e, ao mesmo tempo, plasmou outro tipo de federação. O federalismo clássico e dualista, predominantemente centrífugo, cedia lugar, ao novo federalismo, fundado na extensão dos poderes federais dentro da tendência centrípeta, que inaugurava a fase das relações intergovernamentais, para compensar a plenitude dos poderes da União e a consequente diminuição dos poderes reservados aos Estados", Tendências do Federalismo Brasileiro, in Revista Forense Comemorativa - 100 anos, v. 1, Ob. cit., p. 493.
} 
prevenção e repressão da criminalidade e permuta de informações". Prosseguindo, o art. 10 da aludida Carta fixou também, pela primeira vez no constitucionalismo pátrio, a repartição de competências concorrentes, dando ênfase à solidariedade entre União e os entes federados ${ }^{379}$. Todavia, a cooperação propriamente dita foi celebrada com os dispositivos constantes nos artigos 140 e 177 da Constituição Federal de $1934^{380}$, os quais tratavam do combate às endemias e às secas do Nordeste.

Como é de fácil aferição, atribuiu-se à União a complicada tarefa de conciliar realidades tão distintas, que durante toda a vigência da Primeira República, estiveram amarradas por afrouxados e precários laços federativos. Sob esse prisma, anota MANOEL GONÇALVES FERREIRA FILHO que a "Constituição de 1934 é a primeira que, embora de modo incipiente, tomou consciência da assimetria de condições dos Estados brasileiros. Isto não a levou a quebrar a simetria de seu estatuto constitucional. Entretanto, para propiciar uma política de redução das desigualdades, sociais e regionais, escolheu o caminho da centralização" 381 .

Os ajustes político-constitucionais implantados nesse período levaram à redefinição do federalismo nacional, sobretudo no que respeita à exegese da Lei Maior, uma vez que a interpretação das prescrições lá consignadas passou a exigir sintonia com os condicionantes do pluralismo. $\mathrm{O}$ incentivo à criatividade, o respeito ao particularismo e o compromisso com desenvolvimento equânime em prol de todos os integrantes da Federação transformaram-se em pontos cardeais para assegurar o adequado funcionamento do sistema de descentralização política instituído ${ }^{382}$. A mudança de parâmetros hermenêuticos derivada do dever de cooperação intergovernamental selou o entendimento de que a unidade do Estado federal não pressupõe a desconsideração das diversidades

\footnotetext{
379 “Art. 10 - Compete concorrentemente à União e aos Estados:

I - velar pela guarda da Constituição e das leis;

II - cuidar da saúde e assistência públicas;

III - proteger as belezas naturais e os monumentos de valor histórico ou artístico, podendo impedir a evasão de obras de arte;

IV - promover a colonização;

V - fiscalizar a aplicação das leis sociais;

VI - difundir a instrução pública em todos os seus graus;

VII - criar outros impostos, além dos que lhes são atribuídos privativamente”.

380 “Art. 140 - A União organizará o serviço nacional de combate às grandes endemias do País, cabendo-lhe o custeio, a direção técnica e administrativa nas zonas onde a execução do mesmo exceder as possibilidades dos governos locais"; e "Art. 177 - A defesa contra os efeitos das secas nos Estados do Norte obedecerá a um plano sistemático e será permanente, ficando a cargo da União, que dependerá, com as obras e os serviços de assistência, quantia nunca inferior a quatro por cento da sua receita tributária sem aplicação especial".

${ }^{381}$ Cf. Aspectos do Direito Constitucional Contemporâneo, Ob. cit., p. 176.

382 Cf. LeOnardo Marins, Limites ao Princípio da Simetria Constitucional, in Vinte Anos da Constituição Federal de 1988, Cláudio Pereira de Souza Neto, Daniel Sarmento e Gustavo Binenbojm (coord.), Ob. cit., p. 694.
} 
regionais, haja vista que essa roupagem da Federação prega a conveniência de realizar-se o raciocínio contrário para alcancar o máximo de eficiência com a descentralização do poder político.

O significado da opção feita pelo constituinte daquela época influenciou definitivamente todas as Leis Fundamentais posteriores, tendo em vista que, desde então, a acentuada disparidade socioeconômica das unidades federadas - considerada por JosÉ LUIZ DE ANHAIA MELlo como "a primeira e mais distintiva característica"383 de nossa Federação - passou a receber tratamento jurídico. De fato, coube à concepção do federalismo cooperativo aportar no Direito Constitucional nacional o salutar significado de remeter tratamento às desigualdades regionais, o que abriu caminho para as primeiras iniciativas de acomodar as dramáticas diferenças que foram insistentemente ignoradas na etapa de fundação de nosso Estado Federal. Inquestionavelmente, a efetiva articulação das relações intergovernamentais, sob a supervisão do poder central, buscou, ao menos no plano teórico, remediar os principais pontos responsáveis pela pouca coesão política visualizada no cenário estatal brasileiro antes de 1934.

A ideia de conjugar esforços dos vários governos federados para obter resultados proveitosos para todo o conjunto evidenciou ainda a compreensão, por parte das unidades político-administrativas (e das respectivas lideranças regionais), de que o Estado Federal pressupõe a coexistência em harmonia de todos os seus entes. A doutrina da cooperação entre União e os entes e entre estes assinala que a ajuda mútua dos atores da Federação não pode, sob nenhum aspecto, dar azo à ingerência política, devendo observar, portanto, o princípio da subsidiariedade ${ }^{384}$. Mesmo apresentando problemas quando colocada em execução no país, o saldo propiciado pela cooperação deve ser entendido como positivo, mormente porque algumas das disposições constitucionais da Carta Política de 1934

${ }^{383}$ Ob. cit., p. 32.

${ }^{384}$ Cf. Dircêo Torrecillas Ramos, Organização do Estado: o Estado Federal, in Constituição Federal: Avanços, Contribuições e Modificações no Processo Democrático Brasileiro, Ives Gandra Martins e Francisco Rezek (coord.), São Paulo, Centro de Extensão Universitária e Revista dos Tribunais, 2008, pp. 275-276. A propósito, é oportuno anotar que ARTHUR KAUFMANN definiu genericamente o princípio da subsisidiariedade e as considerações feitas, embora tivessem como foco a relação entre indíviduos e grupos sociais com o Estado, devem ser aplicadas à atuação do poder central em face dos entes periféricos do Estado federal. Registrou o autor apontado que a subsidiariedade "refere-se às funções do Estado. E certamente que está aí em causa um aspecto negativo e um outro positivo. Negativamente, o princípio da subsidiariedade significa que o Estado não deve prestar 'auxílio' quando os indivíduos ou as sociedades parcelares não precisam de tal auxílio; nem mesmo quando seja pedida, como atualmente se diz, uma intervenção 'auxiliar' do Estado. $\mathrm{O}$ outro aspecto respeita à prestação positiva de auxílio quando surgirem tarefas que o indivíduo ou uma comunidade restrita (por exemplo a classe médica) não as pode realizar. Nesse caso o Estado (ou a comunidade superior) não é apenas um mero substituto ou suplente, da mesma forma que por exemplo os pais não são apenas suplentes quando ajudam os filhos nas situações que estes não conseguem resolver apenas por si próprios" (Filosofia do Direito, Lisboa, Fundação Calouste Gulbenkian, 2004, p. 334). 
conseguiram quebrar a inflexibilidade com as diferenças regionais, tão presente nos primeiros tempos de nossa experiência federativa.

Dessa forma conclui-se que, no Brasil, os intentos de acomodação da diversidade territorial sempre estiveram ligados à cooperação estabelecida entre os entes federados. Essa relevante configuração estrutural de nossos Estado, a despeito de ter desembocado na supervalorização da União, constitui a fonte da qual se originaram os engenhos constitucionais conhecidos para remediar os aspectos negativos da heterogeneidade territorial. Com vistas na história constitucional do país, esse fato não pode ser desconsiderado na atualidade, quando se pensa em instrumentos que objetivem atender a esse mesmo propósito ${ }^{385}$, até porque o federalismo cooperativo é, certamente, a matriz mais adequada às exigências contemporâneas de ajustes sociais equitativos ${ }^{386}$. Por conseguinte, tal configuração estatal se firma como base para que o Estado federal assimétrico possa se desenvolver.

Indica DIRCÊO TORRECILlAS RAMOS que a Lei Fundamental de 1934, ao trazer a disposição encartada no art. $5^{\circ}$, inciso $\mathrm{XV}$, apresentou expresso mandamento diferenciador, uma vez que definiu "como competência privativa da União 'organizar a defesa permanente contra os efeitos da seca nos Estados do norte', o que requer um tratamento assimétrico"387. A consagração desse preceito significou, em definitivo, importante passo para a compreensão do quão importante é o nivelamento, em patamares propícios à governabilidade, da vasta diversidade natural e geográfica, bem como das diferenças políticas, que numa constante visível emperraram o pleno desenvolvimento de algumas regiões do país, em especial aquelas que hoje apresentam índices econômicos insatisfatórios.

Embora a admissão do federalismo cooperativo transpareça ser um exercício de racionalidade, resultado da influência dos valores da integração e da eficiência atuantes sobre o fenômeno jurídico-constitucional do federalismo ${ }^{388}$, o caminho percorrido pela União frustrou o intento de se remediar devidamente as consequências da conhecida

\footnotetext{
${ }^{385}$ ORLANDO BITAR assinala que a ordem constitucional estabelecida pelo Constituição de 1934 refletiu o "inelutável crescimento do Estado Moderno e a publicização avassaladora, de que dão testemunho títulos inovados sobre a Família ou a Ordem Econômica e Social. Ao Federalismo segregacionista da I República sucede em paralelo com a evolução constitucional, nos Estados Unidos, o Federalismo orgânico e cooperativo. Normatizam-se as relações intergovernamentais, deixando estas de ser mera exceção, não mais prevalecendo como única abertura a ocorrência de calamidade pública", Federalismo Solidário $e$ Desenvolvimento, ora in Obras Completas de Orlando Bitar: Estudos de Direito Constitucional e Direito do Trabalho, vol. 2, Ob. cit., p. 130.

${ }^{386}$ Cf. NINA RANIERI, Ob. cit., p. 92.

${ }^{387}$ O Federalismo Assimétrico, Ob. cit., p. 168.

${ }^{388}$ Cf. Cristiano Franco Martins, Ob. cit., p. 78.
} 
disparidade regional verificada no país. Acabou o poder central tornando-se uma esfera de governo incontrolável, cujos limites de atuação não mais foram possíveis de ser delimitados com segurança pelas Constituições ulteriores ${ }^{389}$. Tal conduta política retraiu a atuação dos Estados-membros no desenvolvimento de suas ações, pois muitos desses entes, cada vez mais, assumiram a condição de súditos da União, na medida em que o amparo federal passou a ser peça imprescindível na execução de serviços públicos disponibilizados à população.

Numa análise teórica, a cooperação no plano federativo tem por objetivo principal assegurar a manutenção da autonomia dos entes locais, ao mesmo tempo em que também apresenta flexibilidade suficiente para permitir a realização de planos, programas e projetos conjuntos de atuação entre as diversas esferas, sob a coordenação do poder central. No entanto, cabe advertir que a grande questão que se coloca à forma de Estado parece ser a dificuldade de compatibilizar os limitados recursos disponíveis com as múltiplas e diferenciadas necessidades regionais. Esse impasse justifica-se na extremada dificuldade de obter-se uma fórmula política em que haja a maximização das potencialidades econômicas do país como um todo, sem, no entanto, abrir o caminho para excessiva centralização e concentração de poderes ${ }^{390}$.

Sobre o que tem sido tratado e em arremate, assevera GILBERTO BERCOVICI que, “no Brasil, a decisão de descentralizar está, irremediavelmente, ligada à questão histórica das desigualdades regionais, que nunca foram encaradas como prioridade nacional máxima. Desta forma, sem uma real preocupação com as desigualdades regionais, os efeitos da própria descentralização se tornam limitados. E na questão das disparidades regionais, o papel da União é fundamental: os entes federados não podem suprir o planejamento e decisões que exigem visões suprarregionais, nem têm como obter, isoladamente, grandes recursos. Os efeitos da repartição de rendas e encargos foram diferentes nas várias regiões, dado totalmente ignorado pelo Governo Federal, que não pode ser subsidiário (como querem alguns), patrocinando o desmonte de políticas públicas. É a problemática das desigualdades regionais que deve determinar os limites da

\footnotetext{
389 Sobre o fenômeno da ampliação do papel da União no federalismo cooperativo, verificar BERNARD SchwartZ, O Federalismo Norte-Americano Atual: Uma Visão Contemporânea, Rio de Janeiro, Forense Universitária, 1984, pp. 26-45; e Fernanda Dias Menezes de Almeida, Competências na Constituição de 1988, Ob. cit., pp. 20-29.

${ }^{390}$ Cf. Nelson De Freitas Porfírio JúNIOR, Federalismo, Tipos de Estado e Conceito de Estado Federal, in Federalismo Fiscal, Ob. cit., p. 11.
} 
descentralização no Brasil, questão esta que, no processo descoordenado de descentralização que vem ocorrendo no Brasil, foi deixada de lado"391.

\section{IV.1.4. A Negativa Reiterada da Dimensão Municipal nos Pactos Federativos Brasileiros}

Além da ausência de coesão inter-regional que acometeu as unidades estaduais, sobretudo nos primórdios do federalismo no país, e da ampliação desmedida dos poderes da União no funcionamento do federalismo cooperativo após 1934, outro aspecto que contribuiu para dificultar o sucesso das várias experiências federativas ensaiadas foi a constante desconsideração do campo municipal de poder político. Durante a maior parte de nossa história constitucional, os Municípios ficaram completamente abandonados, sendolhes negligenciado o mínimo sopro de autonomia ${ }^{392}$, pois, na vigência da primeira Carta Constitucional republicana, assentou-se o entendimento de que atribuir aos Municípios competência para tomar decisões sobre sua organização seria o mesmo que entregá-los ao sério risco de caírem nas mãos das oligarquias locais corruptas e perdulárias ${ }^{393}$.

Interessa anotar que essa pouca expressividade do localismo político não foi característica apenas da Federação delimitada na Lei Fundamental de 1891, uma vez que todas as Constituições que a sucederam, em maior ou menor grau, acabaram registrando essa tendência até que a Assembleia Nacional Constituinte de 1987/1988 a rompesse expressamente $^{394}$. Em definitivo, foi a atual Lei Maior que considerou o Município

\footnotetext{
${ }^{391}$ Desigualdades Regionais, Estado e Constituição, Ob. cit., p. 183.

392 O marco inicial dessa posição refratária à autonomia municipal está, segundo aponta JoÃo CAMILLO OLIVEIRA TORRES, na animosidade formada entre a ideologia federalista e as pretensões municipalistas após a edição do Ato Adicional de 1834, que retirou poder dos Municípios e o colocou nas Províncias (Cf. Ob. cit., pp. 196-197). Em posição contrária, ALESSANDRA SILVEIRA não visualiza hostilidade em relação à autonomia municipal no mencionado documento de 1834, ao entender que, "coerente com o espírito federativo que o inspirava, o Ato Adicional devolvia às Províncias a organização dos municípios que as integrassem. Mas como os estadistas do Império sempre resistiram à federação por incompatível com as instituições monárquicas - entre as quais a autonomia municipal - o argumento de secundarização dos Municípios foi capitalizado para amesquinhar o poder das Assembleias Provinciais", Ob. cit., p. 82; e também José de Castro Nunes, Do Estado Federado e sua Organização Municipal, Brasília, Câmara dos Deputados, 1982, pp. 57-58.

${ }^{393}$ Cf. VICTOR NuNES LEAL, Coronelismo, Enxada e Voto, Ob. cit., pp.50-53.

${ }^{394}$ Segundo Pedro Estevam Alves Pinto SerRano, "o entendimento de separar o Município da realidade federativa brasileira pode ser explicado pelo antiquado apego culturalmente servil ao modelo federativo dual norte-americano. Esse entender não atenta à evolução enfrentada pelo Estado Federal como instituto político e fenômeno cultural, que nem sequer em sua essência perfaz imutável", Região Metropolitana e seu Regime Constitucional, São Paulo, Verbatim, 2009, p. 107.
} 
verdadeiro ente federado e, por conta disso, buscou criar condições factíveis - ao menos em tese - para que a autonomia municipal fosse exercitável no plano da vida local ${ }^{395}$.

Para além desse reconhecimento, no seio da última Constituinte ficou registrada também a justificada preocupação dos membros da Subcomissão de Municípios e Regiões a respeito das disparidades verificadas entre as realidades municipais. Na ata da $3^{\mathrm{a}}$ Reunião Ordinária realizada pela aludida Subcomissão, ocorrida em 22 de abril de 1987, o constituinte NiVALDO KRIERGER assim externou seu posicionamento: "Será impossível reorganizarmos a Federação com base num princípio genérico, tratando igualmente entes desiguais. Essa desigualdade das regiões - para nos atermos ao tema da Subcomissão precisa ser considerada. Para isso, é preciso também que, dentro das regiões, sejam consideradas, objetiva e, praticamente, as condições peculiares de municípios típicos e atípicos"396.

Infere-se, pois, que, na obra do poder constituinte resultada em 05 de outubro de 1988, foi firmada a certeza de que os governos municipais deveriam ser integrados de uma vez por todas ao universo do federalismo brasileiro. $\mathrm{O}$ ineditismo da conformação federativa estabelecida pelo art. 18 da atual Lei Fundamental, ao consignar que a organização político-administrativa do Estado compreende a União, os Estados, o Distrito Federal e os Municípios, todos autônomos, consagrou a orientação de que era preciso superar as conhecidas e vetustas posições refratárias à autonomia municipal, garantindo-se aos entes locais liberdade política para atender suas exigências e interesses próprios.

Essa diretriz, ao ser transposta para o plano constitucional, representou destacado passo na caminhada do país pela efetiva descentralização política. Consoante sublinha JosÉ ALFREDO DE OLIVEIRA BARACHO, o municipalismo, fortemente prestigiado na ordem

\footnotetext{
395 Sobre a autonomia municipal no Brasil, Hely LOPES MEIRELLES, reconhecido defensor do municipalismo, apresenta emblemático panorama histórico-constitucional, no qual esclarece, em resumo, que até a Lei Fundamental de 1946 o Município tinha apenas autonomia nominal, isto é, encontrava-se completamente tolhido do poder de auto-organização, além de ser privado da liberdade mínima para o exercício real do poder político que lhe era destinado. $\mathrm{O}$ administrativista demonstra ainda que coube à atual Carta Constitucional promover a inequívoca integração do Município na estrutura da Federação nacional, transformando-o em verdadeira entidade federada, assegurado-lhes competências privativas e concorrentes para a edição de leis, além de ter havido a ampliação significativa do poder do mesmo para tributar e também para participar nos impostos partilhados (Cf. Direito Municipal Brasileiro, $15^{\mathrm{a}}$ ed., São Paulo, Malheiros, 2007, pp. 31-47). No tocante ao enquadramento do Município na Federação brasileira, consultar ainda Fernanda Dias Menezes de Almeida, Atividade Constituinte nos Estados e nos Municípios, Ob. cit., pp.77-84.

396 Brasil, Diário da Assembleia Nacional Constituinte (Suplemento), Subcomissão dos Municípios e Regiões, Brasília, Senado Federal, Centro Gráfico, p. 19. Na mesma sessão ordinária da Subcomissão voltada a analisar os interesses municipais e regionais JORGE KHOURY HEDAYE, então presidente da Confederação Nacional de Municípios e prefeito de Juazeiro, Estado da Bahia, reafirmou a relevância de se observar que os diversificados contextos apresentados pelos Municípios, na exata medida em que os mesmos apresentam inquestionáveis e conflitantes condições econômico-sociais entre si, Cf. Idem, pp. 22-23.
} 
constitucional em vigor, permitiu o estreitamento dos laços entre Estado e comunidade, facilitando, por consequência, o planejamento e a operacionalização de políticas sociais ao propiciar maior interação entre o poder central e os poderes periféricos. Assinale-se que tais relacionamentos são especialmente importantes para o Brasil, tendo em vista a existência de uma sólida base comunal no país ${ }^{397}$.

Não obstante as benesses decorrentes da capacidade de auto-organização assegurada aos entes municipais, assistiu-se a materialização de um trágico quadro de multiplicação de penúria enfrentada por muitos dos Municípios brasileiros. Além disso, ocorreu o surgimento de uma série de problemas ligados à disposição dos Municípios diante dos outros atores do conjunto federativo nacional, os quais levaram ao acirramento das assimetrias relacionais no país. Não há dúvidas de que as antinomias entre tais entes federados agravaram-se em muito, e as relações intergovernamentais típicas do federalismo cooperativo acabaram tendo de lidar com esse universo absurdamente inconstante.

A consagração da autonomia municipal ocasionou a formação de um quadro bastante interessante para o federalismo nacional. De um lado, proporcionou que as demandas locais pudessem ser atendidas com maior presteza e de modo individualizado, tomando como base as peculiaridades dos inúmeros contextos locais, haja vista que o localismo, como consequência, aproximou sensivelmente os centros de decisões políticas da população diretamente interessada nos resultados das ações governamentais empreendidas. Noutro sentido, ampliaram-se as disparidades territoriais porque, numa perspectiva alargada, com a maior diferenciação entre os atores políticos situados em uma mesma região, aumentam-se também as desigualdades intrarregionais.

O municipalismo admitido pela Constituição de 1988 desencadeou a intensificação das desigualdades, as quais agora não mais estão circunscritas apenas entre as regiões ou entre os Estados-membros. No âmbito interno de cada uma dessas regiões, passaram a ocorrer atuações políticas em diferentes velocidades, cada qual atendendo a propósitos

397 Cf. O Princípio da Subsidiariedade: Conceito e Evolução, in Revista de Direito Administrativo, v. 200, abril/junho 1995, p. 25. Confirma e ilustra essa assertiva o paradigmático estudo comparatístico realizado por SuEli GANDOLFI DALlaRI, que tomou como base a rede de prestação dos serviços públicos de saúde na Federação brasileira moldada pela Constituição Federal de 1988. Depois de análises centradas nos encargos gravados a cada um dos entes federados para a implementação dos serviços apreciados, a autora concluiu que, "sem dúvida, a esfera do poder político que detém a maior parcela de responsabilidade pela execução das ações e serviços de saúde - conforme o disposto no pacto nacional de 1988 - é o município. Com efeito, nem mesmo a instituição do Sistema Único de Saúde ou a distribuição comum a todas as esferas das funções de prevenção, defesa e cuidado sanitário, anulou a obrigação posta especialmente aos municípios de - com a cooperação técnica e financeira da União e dos Estados - prestar serviços de atendimento à saúde da população (CF, art. 30, VII)", Os Estados Brasileiros e o Direito à Saúde, São Paulo, Hucitec, 1995, p. 105. 
variados, defendidos pelo vasto número de Municípios brasileiros. Inevitavelmente, ocorreu o aumento da diversidade entre os entes municipais vinculados a Estados específicos. Ao menos no que se refere à formulação de ações governamentais conjuntas, os contrastes territoriais no seio de nosso Estado federal foram elevados drasticamente, o que ainda exige da engenharia constitucional soluções cada vez mais desafiadoras.

Corolário lógico desse processo, a problemática da desigualdade federativa, sempre analisada sob a ótica inter-regional, desde então, passou a demandar apreciações reflexivas com foco nas heterogeneidades apuradas na escala intrarregional. A introdução definitiva dos entes municipais no esquema organizativo da Federação brasileira transformou-a num terreno repleto de estruturas jurídico-políticas ainda mais complexas, as quais tiveram de ser aperfeiçoadas para garantir o atendimento da autonomia municipal. Com o interesse local igualmente tutelado pela ordem constitucional vigente, o delicado planejamento das relações intergovernamentais, anteriormente centrado apenas na composição de entendimentos entre o governo federal e os Estados, deve, a partir de 1988, por expressa disposição da Carta Maior, equacionar ainda a dimensão municipal.

O localismo, reiteradamente ignorado pelas Constituições anteriores, forçou a reelaboração dos laços associativos, de modo a aproximar-se a Federação nacional da orientação esquadrinhada por GERALDO ATALIBA, no sentido de que a autonomia dos Municípios estaria na base do princípio republicano e, por isso, sempre compareceu como o mais importante e transcendental dos princípios do nosso direito público ${ }^{398}$. Esse processo ainda está inconcluso, uma vez que não são sabidos quais foram, de fato, todos os impactos causados pelas reformas sucedidas com advento de um verdadeiro autogoverno municipal. A ampla heterogeneidade que marca o território brasileiro, distribuída por uma rede de atores que compreende vinte e seis Estados e cerca de seis mil Municípios, coloca à engenharia constitucional a incumbência de ajustar esse enredado contexto, em que há conflitos estruturais persistentes e comprometedores, geralmente de natureza redistributiva, que se exacerbam em períodos de profundas mudanças e que, em regra, estão focados no controle dos recursos políticos disponíveis ${ }^{399}$.

Não foi à toa que AIRES BARRETO lançou contundente advertência, já nos primeiros períodos de aplicação da Carta Constitucional em vigor no país, chamando a atenção para o ponto de que, em relação aos Municípios, tratá-los igualmente seria um grande e

\footnotetext{
${ }^{398}$ Cf. República e Constituição, $2^{\mathrm{a}}$ ed., São Paulo, Malheiros, 2004, p. 25.

${ }^{399}$ Cf. Aspásia CAmargo, A Reforma-Mater: Os Riscos (e os Custos) do Federalismo Incompleto, Ob. cit., p. 80.
} 
lamentável equívoco. Segundo observou, “deveríamos, ao menos, classificá-los, separá-los, segundo suas grandes vocações. Nós temos Municípios urbanos, temos Municípios rurais, Municípios dormitórios, Municípios turísticos. Essas peculiaridades, especificidades, não permitem um tratamento idêntico, genérico, sem resvalar em injustiças" ${ }^{\star 400}$. Com efeito, se a União e as autoridades estaduais estabelecerem relacionamentos com os Municípios e o tratamento desenvolvido estiver estritamente ancorado na igualdade formal, ter-se-á potente catalisador das problemáticas desigualdades do pacto federativo formulado, o qual ainda se encontra em processo de aperfeiçoamento.

Interessa, nesse ponto, proceder à análise do elucidativo quadro tecido por ASPÁSIA CARMAGO acerca do quão complicado foi para o sistema federativo brasileiro ter elevado o Município à categoria de ente autônomo. Depois de esclarecer que o ambiente de intensas negociações e barganhas decorrente do federalismo cooperativo levou ao aparecimento de aspectos desestruturantes do Estado, a autora apresenta como exemplos confirmatórios de sua tese, as externalidades que desembocaram na criação descontrolada de Municípios e a instauração de políticas predatórias fiscais por determinados entes, inclusive por alguns Municípios dotados de condições financeiras favoráveis ${ }^{401}$.

Em particular, no que diz se refere ao surgimento de expressivo número de Municípios (muitos deles sem a menor possibilidade de, com receitas próprias, manter os serviços públicos essenciais à população), há que se anotar que vários desses entes federados surgiram movidos pelo único propósito de receber fatia do Fundo de Participação disponibilizado pelo Governo Federal (FPM) ${ }^{402}$. Daí porque foi promulgada a

\footnotetext{
${ }^{400}$ Os Municípios na Nova Constituição Brasileira, in A Constituição Brasileira 1988: Interpretações, Ives Gandra da Silva Martins (coord.), Rio de Janeiro, Forense Universitária, 1988, p. 81. Na mesma direção, José Afonso DA SILVA, em 1984, expôs no Simpósio “Constituinte em Debate”, realizado pela Comissão de Constituição e Justiça da Assembleia Legislativa do Rio Grande do Sul, seu entendimento nos seguintes termos: "O sistema municipal brasileiro carece de profunda reformulação, com organização diferente à vista de fatores, inclusive com a reintegração, em outros, de Municípios claramente inviáveis. Talvez seja aconselhável criar tipos diversos de organização municipal, tendo em vista, por exemplo, suas características de rurais, industriais e de capitais, com tratamento constitucional diferenciado, inclusive do ponto de vista tributário", Constituinte: Caminho para uma Nova Ordem Constitucional, in Estudos Legislativos, ano 3, $\mathrm{n}^{\circ}$ especial, 2009, p. 32.

${ }^{401}$ Cf. A Reforma-Mater: Os Riscos (e os Custos) do Federalismo Incompleto, Ob. cit., p. 83.

402 Acerca da facilidade de criação de Municípios no Brasil, registram EDUARDo KugELMAS e LOURDES SolA que esse dado representa consequência inevitável da consagração da autonomia assegurada para esse ente pelo constituinte, ressaltando o fato de que a participação na distribuição do FPM é direito automaticamente garantido ao Município que surge na Federação nacional. Informam que, de 1988 a 1997, o número de Municípios no país passou de 4.198 a 5.507, o que determinou a pulverização dessas receitas após o alargamento do número de beneficiários. Ainda referenciam a estimativa de que a quase totalidade dos entes municipais com população até a casa de dez mil habitantes depende do FPM na proporção de, aproximadamente, três quintos de suas dotações orçamentárias, o que, na percepção de ambos os autores, exige que seja repensada a dimensão federativa nas reformas que serão feitas no Estado, Cf. La Construcción del Federalismo Democrático en Brasil, in ICE: Revista de Economía, nº 810, 2003, pp. 115-116.
} 
Emenda Constitucional no 15, de 12 de setembro de 1996, que conferiu nova redação ao art. $18, \S 4^{\circ}$, da Constituição Federal ${ }^{403}$ e objetivou declaradamente dificultar e tornar mais responsável o processo de criação de novas unidades federativas municipais. Como bem repara PAUlo GuSTAVo GONET BRAnCO, "essas exigências apertadas devem-se à necessidade de reprimir a proliferação de novos entes municipais, nem sempre animada, de modo claro, por motivos de real interesse público" ${ }^{404}$.

A aludida alteração veio, sem dúvida, remediar séria distorção causada ao Estado brasileiro pela ascensão do municipalismo em 1988. Trata-se de erro de pressuposição, por parte do constituinte originário, de que os Estados-membros iriam apenas proceder à criação de novos Municípios quando certificados de que esses entes criados, incorporados fundidos ou desmembrados detivessem autossustentação financeira ${ }^{405}$. Na prática, antes da Emenda Constitucional no 15/1996, conforme grifou o Ministro SEPÚlVEDA PERTENCE, no julgamento da ADI no 2.381-RS (que reconheceu a constitucionalidade do ato reformador em questão), a manipulação das regras sobre criação de Municípios trouxe resultados desastrosos à Federação, mormente porque as Assembleias Legislativas estaduais não conseguiram resistir aos movimentos emancipacionistas locais, geralmente guiados por interesses eleitoreiros ${ }^{406}$.

O resultado desse quadro foi, tal qual é notoriamente conhecido, a proliferação de Municípios inviáveis no território nacional como um todo. A criação irresponsável desses entes federados fragilizou, em demasia, a articulação das relações intergovernamentais no país, uma vez que, não raro, as unidades locais de poder não conseguem - seja por carência crônica de recursos, seja pelo descompromisso com o autogoverno - dar cumprimento aos encargos e aos trabalhos que lhes são atribuídos em ações conjuntas entre os governos federal e estadual. Além disso, gama considerável de entes municipais está em total estado de submissão em relação à União e aos Estados, na medida em que, para conseguir assegurar a sobrevivência de suas precárias instituições políticas, depende de constantes repasses, disponibilizados por esses entes.

\footnotetext{
403 “Art. $18-[\ldots]$

$\S 4^{\circ}$ A criação, a incorporação, a fusão e o desmembramento de Municípios, far-se-ão por lei estadual, dentro do período determinado por Lei Complementar Federal, e dependerão de consulta prévia, mediante plebiscito, às populações dos Municípios envolvidos, após divulgação dos Estudos de Viabilidade Municipal, apresentados e publicados na forma da lei”.

404 Organização do Estado, in Curso de Direito Constitucional, Gilmar Ferreira Mendes, Inocêncio Mártires Coelho e Paulo Gustavo Gonet Branco, Ob. cit., p. 865.

405 Cf. STF, ADI no 2395-RS, Pleno, Relator Ministro GILMAR MENDES, julgamento: 09/05/2007, DJe 23/05/2008, p. 122 (voto do Ministro CARLOS BRITTO).

${ }^{406}$ Cf. STF, ADI no 2381-RS, Pleno, Relator Ministro Sepúlveda Pertence, julgamento: 20/06/2001, DJ 14/12/2001, p. 23 (voto do Relator).
} 
Em abono, RUI DE BRITTO Álvares AFFOnSo enfatiza que o aparecimento de novos Municípios no país - muitos dos quais sem base econômica ou fiscal própria - fez com que se limitassem consideravelmente "as possibilidades de coordenação federativa e de que se estabeleça uma coordenação federativa e de que se estabeleça uma correspondência satisfatória entre responsabilidades e capacidade financeira deste nível de governo" ${ }^{, 407}$. A enorme heterogeneidade socioeconômica regional, intensificada com o sensível aumento do número de atores políticos municipais, impede que o federalismo pátrio insista em destinar tratamento uniforme aos entes situados em um mesmo nível de governo, porque essa prática acaba acirrando ainda mais os preocupantes efeitos da diversidade $^{408}$. Do assinalado, depreende-se, com clareza, que a vontade do constituinte de introduzir os Municípios no sistema territorial de descentralização do poder político provocou sérias consequências na estrutura do Estado nacional, cujos reparos apontam diretamente para a aplicação dos postulados da assimetria federativa.

Assim, com esteio no que estatui RAUL MACHADO HORTA, é preciso assentar que a “expressão do federalismo assimétrico da Constituição reside na regra que introduziu o Município na composição da República Federal, no art. $1^{\circ}$ da Constituição, reiterada na enumeração das pessoas jurídicas que integram a organização político-administrativa da República (art. 18)" ${ }^{\circledR 409}$. Entretanto, não é a mera previsão de autonomia municipal que determina a configuração assimétrica do Estado brasileiro, haja vista que, para existir verdadeiramente, a assimetria requer muito mais do que disposições constitucionais heterodoxas que fujam aos padrões geralmente estabelecidos pela teoria geral do federalismo. Exige-se, antes de qualquer outro aspecto, que os arranjos jurídicoinstitucionais da Federação estejam fielmente compromissados em garantir o máximo de êxito no funcionamento das estruturas concebidas e disponibilizadas pela ordem constitucional para efetivar a descentralização política.

Por tais razões, propõe-se aqui que o pensamento teórico da assimetria venha a ser desenvolvido e concretamente empregado como o garante principal da autonomia municipal, mesmo diante da situação de extrema carência vivenciada por muitos Municípios no Brasil. Para além de uma situação na qual o texto constitucional traga disposições vagas e impossíveis de serem aplicadas no plano da realidade, o regime federativo arquitetado em consonância com os postulados da assimetria poderá tornar-se

\footnotetext{
${ }^{407}$ A Federação na Encruzilhada, Ob. cit., p. 36.

${ }^{408}$ Cf. Idem, ibidem.

${ }^{409}$ Direito Constitucional, $3^{\mathrm{a}}$ ed., Belo Horizonte, Del Rey, 2002, p. 497.
} 
uma experiência exitosa, na medida em que o balanceamento das disparidades verificadas permite que se vençam obstáculos antes intransponíveis, como seria o caso daquelas unidades municipais estagnadas, que já nasceram sem nenhuma perspectiva real de vida autônoma.

Vários dos Municípios criados após a promulgação da atual Constituição devem ter, no Estado federal assimétrico, a esperança de que aquelas adversidades que atravancam seu pleno desenvolvimento poderão ser contornadas e, com isso, virão eles saber o que, de fato, significa o exercício livre do autogoverno, ponto chave da forma federativa de Estado. A importância da tomada de tais medidas é imensa, tão significativa a ponto de justificar, por exemplo, tratamentos diferenciados aos entes municipais na inteira proporção de suas respectivas desigualdades territoriais. Ainda que seja necessário instituir instrumentos corretivos não-convencionais que tragam clara distinção entre as unidades federativas em que serão aplicados, é certo que o manuseio adequado desses recursos importará em inegáveis ganhos para toda a Federação.

\section{IV.2. A Origem e o Desenvolvimento do Estado Federal no Brasil sob o Enfoque da Assimetria}

Do resumido escorço histórico apresentado, podem-se tirar algumas anotações conclusivas acerca do processo de estabelecimento de variantes assimétricas no campo do federalismo brasileiro. Assim, chega-se ao entendimento de que, embora o conceito de assimetria federativa fosse totalmente desconhecido antes da década de 1960 pela doutrina constitucional, é possível afirmar que, no Brasil, a história do federalismo nacional foi determinante para impedir adoção mais enfática dos instrumentos de assimetria. De fato, a resistência em consagrar, em nossas Constituições - inclusive nas posteriores ao surgimento da tese em questão -, os mecanismos jurídicos de compensação das diversidades territoriais repousa, em parte, no amplo acolhimento da concepção de Estado federal simetricamente planejado tão enaltecida nos primeiros tempos da República.

Esse panorama comprometedor é orientado por dois graves embaraços incrustados na arquitetura do Estado brasileiro. Alguns aspectos prejudicaram (e ainda emperram) o pleno desenvolvimento do regime federativo no país. O primeiro - referido por CLAUDIO PACHECO -, foi o descuido da idealização extremada, o excessivo apego às belas palavras que influenciou e ainda exerce domínio sobre nossos planejadores políticos, de modo que, 
entre nós, a ideia de Federação apresenta-se, fantasiada, "passando por cima da nossa realidade coletiva e ultrapassando até mesmo as suas mais certas possibilidades de realização" ${ }^{410}$. OLIVEIRA VIANNA, por sua vez, acusou o segundo lapso: o erro da simetria, pelo qual se atribui "uma mesma autonomia a todos os Estados, qualquer que seja o seu grau de cultura política e a estrutura íntima da sua sociedade. Daí esses resultados divergentes: o progresso ao lado da rotina, a marcha para diante, larga e desassombrada, de uns, e a marcha para trás de outros, rápida e incoercível"411.

A aplicação das propostas de assimetria federativa à realidade brasileira afina-se, portanto, à intenção de solucionar o mais problemático ponto de tensão do federalismo no país: o das disparidades regionais ensejadoras de desequilíbrios sociais e econômicos. Decerto não é estranho ao princípio federativo tratar da diversidade territorial entre parcelas do Estado, até porque essa é a principal promessa difundida por esse regime, entretanto, em situações específicas, em função da complexidade dos fatores que diferenciam os entes federados, é recomendável o emprego de esquemas heterodoxos de engenharia constitucional para coibir a corrosão dos laços que mantêm unidas as partes do conjunto $^{412}$.

A dificuldade maior que se coloca ao federalismo brasileiro seguramente é a de construir, por meio de técnicas talvez ainda não experimentadas ao longo de nossas Constituições, um fundado esquema de repartição de competências e de encargos entre os multifacetários entes que compõem a Federação. Esse quadro desafiador e de difícil

\footnotetext{
${ }^{410}$ Cf. Ob. cit., p. 347. Também nessa esteira, Rosa MARIA GODOY SILVEIRA assevera que a "bibliografia republicana sobre Federalismo é fértil, mas paradoxalmente pobre", uma vez que a maioria das obras que tratam do tema vale-se de uma perspectiva político-jurídica limítrofe da pura teoria, omitindo-se no tocante à apresentação de uma visão integrada, na qual os componentes socioeconômicos sejam considerados. Ficam circunscritas à ideia de que a Federação resultou apenas do confronto entre localismo e centralismo nos tempos últimos do Império, sendo revestidas muitas vezes de um tom hipotético e ensaístico, porque se referem tão-somente ao aparato jurídico-constitucional da organização política brasileira, sem traduzir preocupações com os mecanismos de funcionamento concreto do Estado, Cf. Ob. cit., p. 55.

${ }^{411}$ Cf. Ob. cit., p. 325.

${ }^{412}$ Em igual norte, RAUl MACHADO Horta entende que o aspecto mais significativo do federalismo assimétrico está na ruptura das linhas clássicas do federalismo com o consequente estabelecimento de deformações no estilo e nas regras federais, isto é, a positivação de normas constitucionais reveladoras de atipicidades e particularizações quando comparadas com os tradicionais esquemas que asseguram a perpetuação da teoria geral do federalismo. O autor mineiro, no entanto, deixa de fazer menção ao conteúdo das normas constitucionais que definiriam o predicado assimétrico a uma dada Federação (Cf. Direito Constitucional, Ob. cit., p. 495). Tal posição também é avalizada pelo Tribunal de Justiça do Estado de Minas Gerais nos seguintes julgados: Ação Direta de Inconstitucionalidade, Processo ${ }^{\circ}$ 1.0000.00.2606697/000(1), Relator Desembargador SÉRGIO LELLIS SANTIAGO, Relator do Acórdão Desembargador CoRRÊA DE MARINS, data de julgamento: 11/12/2002, data de publicação 19/02/2003; e Ação Direta de Inconstitucionalidade, Processo $\mathrm{n}^{\circ} 1.0000 .05 .428781-8 / 000(2)$, Relator Desembargador CARREIRA MACHADO, Relator do Acórdão AlmeIDA Melo, data de julgamento: 22/11/2006, data de publicação: 09/02/2007; textos extraídos de documentos digitais disponíveis no sítio eletrônico: http://www.tjmg.jus.br, acesso em 30/12/2009.
} 
solução sinaliza fortemente para a conveniência de se incorporar ao regramento nacional responsável pelo funcionamento do federalismo os instrumentos de assimetria. O objetivo central dessa proposta está, sem dúvida, na busca do equilíbrio por meio da diferenciação razoável na distribuição de poderes e de tarefas entre as unidades federadas, levando-se em conta a exata proporção suportada por cada um de nossos entes.

Consoante propõe ALESSANDRA SILVEIRA, é fundamental que se rume em direção ao alcance de um projeto federativo em que exista ajuste entre os imperativos de equilíbrio financeiro e de substancial homogeneidade entre todas as componentes federadas. Em tal contexto, a homogeneização aventada implicaria progressiva diminuição das antinomias regionais em favor da tendencial equiparação das situações jurídicas e das condições de vida em todo o território nacional. Importante não confundir a proposta de promover equilíbrio entre os integrantes do concerto federativo com o grave equívoco de instaurar a uniformidade na Federação ${ }^{413}$.

Ao se tomar por base os entes federados alinhados no pacto federativo brasileiro, perceber-se-á com facilidade que, ainda que fossem empregados inúmeros mecanismos jurídicos, seria impossível uniformizar todos eles. Haveria um induvidoso fracasso de eventual proposta tentada nesse sentido, pois haveria a negativa da característica mais enriquecedora do regime federativo, qual seja, a própria diversidade territorial das partes federadas. O ideal, então, é ajustar e corrigir os problemas advindos da heterogeneidade por meio da Constituição, sendo que, no Brasil, esse tratamento passa necessariamente pelo prestígio do postulado da solidariedade que informa o federalismo cooperativo.

Noutras palavras, entre nós, primar pelo Estado federal assimétrico, tal qual verificado, importará no revigoramento das relações intergovernamentais praticadas por entes federados que ostentam sensíveis diferenças entre si. Será preciso evitar que as disparidades regionais continuem a ser fatores de desproporção e de entrave à viabilização do sistema federativo ${ }^{414}$, o que promete fazer com que deixem de existir Estados e Municípios comumente agraciados com privilégios e benefícios junto ao governo federal. A assimetria conformada à realidade brasileira, quando for fiel às disposições constitucionais e estiver seriamente estabelecida nelas, pode conduzir ao triunfo dos esforços em exterminar os resquícios da indevida hierarquização entre as unidades federadas, situação que tem sua gênese, como visto, nos primórdios do federalismo nacional.

${ }^{413}$ Ob. cit., p. 69.

${ }^{414}$ Idem, ibidem. 
A redefinição do pacto federativo no país, para colocá-lo em consonância com as vertentes do Estado federal assimétrico, prenuncia o atendimento de dúplice propósito: eliminar a discriminação sofrida pelas partes do conjunto que não gozam de destacada posição político-econômica e impedir a padronização absoluta de tratamento constitucional dispensado a elas. Além de ganhar em eficiência, essa configuração da Federação aparenta ser opção possível para concretizar a percepção esposada por MiSABEL ABREU MACHADO DERZI de que "a decisão por um Estado Federal é uma decisão pela liberdade e não deixa de ser uma decisão pela igualdade, na medida em que se respeitam as diferenças e peculiaridades locais e regionais. Tal respeito, ao mesmo tempo, torna essas disparidades menos relevantes ou menos radicais" ${ }^{415}$

\section{IV.3. O Federalismo Assimétrico no Brasil: a Redefinição da Cooperação Federativa e o Objetivo de Reduzir as Desigualdades Sociais e Regionais no País}

O esforço na propagação da tese do federalismo assimétrico com vistas a aplicá-la abertamente no contexto nacional denota a crença de que o regime federativo pode ser um valioso instrumento de superação dos problemas derivados das desigualdades regionais que há muito fragilizam nosso modelo de Estado. Embora a noção de assimetria tenha sido cunhada cientificamente nos Estados Unidos (da mesma forma que os ideais federativos, encartados na célebre obra "O Federalista”, de HAMILTON, MADISON e JAY) e utilizada com maior intensidade por outros países, como é o caso do Canadá e da Índia, após a década de 60 do século XX, transpô-la para o Brasil certamente não importará no cometimento do erro mais comum e sempre criticado em estudos comparatísticos de Direito: o equívoco de reduzir os institutos jurídicos unicamente ao plano normativo, desconsiderando-se por completo os demais fatores que influem no sucesso ou no fracasso das experiências estrangeiras.

A incorporação de paradigmas e de modelos jurídicos vindos de outros ordenamentos não poderá jamais ignorar os registros históricos e políticos de cada Estado, bem como deixar de atentar para as diferenças que pode haver entre o ambiente econômico-social no qual o instituto surgiu e é satisfatoriamente utilizado, e aquele espaço em que se pretende introduzi-lo sem nenhuma adaptação ${ }^{416}$. No geral, toda tentativa de aproveitar institutos de Direito Comparado que ignorar essa advertência certamente estará

\footnotetext{
${ }^{415}$ Nota de atualização à obra de AlIOMAR BALEeIro, Direito Tributário Brasileiro, Ob. cit., p. 124.

${ }^{416}$ Cf. PAOlO BisCARETTI DI RuFFIA, Ob. cit., p. 90.
} 
fadada ao insucesso ou ao esvaziamento das possibilidades ofertadas, em tese, pela manobra jurídica realizada. As adaptações e os ajustamentos são imprescindíveis para assegurar o êxito de empreitadas dessa natureza.

Nesse ponto, vale consignar que essa é uma severa censura comumente feita aos republicanos de 1891, destacadamente a Rui Barbosa, que reproduziu o arcabouço federativo dos Estados Unidos deixando de levar em conta as peculiaridades da trajetória constitucional do Brasil até então definidas ${ }^{417}$. O mesmo não poderá ser dito, aprioristicamente, em relação ao pretenso emprego, no país, do federalismo assimétrico em patamares coerentes, uma vez que, nesse caso, terá de se percorrer o caminho diverso daquele feito pelo constituinte da República no final do século XIX. A assimetria demonstra estar alinhada aos novéis paradigmas de estruturação do regime federativo, porque preconiza não apenas o respeito ao pluralismo substancialmente assentado nas múltiplas variantes que determinam as características de cada Federação, mas, sobretudo, ao anunciar que é essencial adaptar os preceitos jurídicos ligados à forma de Estado aos reais contornos da ordem social. Do contrário, jamais será obtido equilíbrio entre as múltiplas forças de tensão que geralmente surgem de bases unitárias e homogêneas ${ }^{418}$.

Pelo que se depreende, a contrariedade entre esses dois processos de adoção de teorias estrangeiras reside na constatação de que, com a assimetria, será impossível copiar, com total desapego à realidade brasileira, as propostas de descentralização política apresentadas, já que sua essência está justamente no preciso diagnóstico dos elementos que, em tese, comprometem o pleno desempenho das autonomias conferidas aos diferentes entes federados. Insistir na assimetria é, sem dúvida, muito mais do que celebrar a diversidade e encará-la como condição inseparável do federalismo. Significa a compreensão de que os desníveis de poder e de características fáticas entre as unidades federadas deverão ser corrigidos com a intenção de colocá-las em paridade substancial.

Ademais, está jungida ao conceito de assimetria a noção de que as heterogeneidades fáticas comprovadas nos territórios, quando complicadoras do funcionamento do regime estabelecido, devem ser superadas pela previsão no texto

\footnotetext{
${ }^{417}$ Manoel Gonçalves Ferreira Filho, Curso de Direito Constitucional, 35a ed., São Paulo, Saraiva, 2009, p. 59; Luís Roberto Barroso, Ob. cit., p. 29; e Fernando Luiz Abrucio, Os Laços Federativos Brasileiros: Avanços, Obstáculos e Dilemas no Processo de Coordenação Intergovernamental, Tese de Doutorado, Faculdade de Filosofia, Letras e Ciências Humanas da USP, São Paulo, 2000, pp. 27-28; PAULO Bonavides, A Constituição Aberta: Temas Políticos e Constitucionais da Atualidade, com ênfase no Federalismo das Regiões, Ob. cit., p. 363-364; entre outros.

${ }^{418}$ Cf. José Alfredo Oliveira BARACho, O Princípio da Subsidiariedade: Conceito e Evolução, Ob. cit., p. 24.
} 
constitucional de instrumentos jurídicos habilitados a compensá-las ${ }^{419}$. Tal aspecto demandará, antes de qualquer ação estatal, prévia definição dos reais aspectos que dificultam a coesão e a sistematicidade de nosso Estado federal, de maneira que os institutos jurídicos estrangeiros vinculados à assimetria apenas deverão ser aproveitados caso mostrem ser interessantes e eficientes para a solução dos conhecidos problemas nacionais.

Assim, por exemplo, não haveria nenhum motivo justificador para atribuir-se estatura constitucional ao respeito do bilinguismo de um Estado-membro específico da Federação brasileira, tal qual acontece com Quebec no Canadá ${ }^{420}$, pois embates culturais não figuram, no país, como fator desagregador da ordem estabelecida. O mesmo não pode ser afirmado no tocante à hipótese de haver previsões instituidoras de arranjos constitucionais assecuratórios de cargas tributárias diminutas para regiões menos desenvolvidas com o objetivo precípuo de fomentar o crescimento das mesmas, assim como ocorre na Alemanha reunificada ${ }^{421}$. Nesse caso, a manifesta diversidade que permeia as economias, as geografias e as sociedades regionais indica a adequação da iniciativa de estruturar-se um sistema tributário adequado a essa sobressalente característica do federalismo brasileiro ${ }^{422}$.

Aclarado está, portanto, que, se a Federação brasileira vier a ser arquitetada de acordo com os paradigmas assinalados pela assimetria, ter-se-á a valorização da diversidade que dimana de nosso meio social. Diferenças territoriais que, aliadas aos

${ }^{419}$ Em idêntica direção Celina SouZA, que, após admitir que, no Brasil, os problemas mais drásticos colocados ao federalismo expressam velhos e não resolvidos conflitos políticos originados em um país social e regionalmente muito desigual, preconiza a necessidade de se empreender uma análise pormenorizada das entidades subnacionais que integram a Federação, sobretudo porque, com o advento da Constituição Federal de 1988, esses entes tiveram considerável ampliação de seu papel no tocante à prestação de serviços sociais e em relação à consolidação das instituições democráticas, Cf. Federalismo e o Gasto Social no Brasil: Tensões e Tendências, in Lua Nova, $\mathrm{n}^{\circ}$ 52, 2001, pp. 5-10.

${ }_{420}$ Para o aprofundamento dos conhecimentos relativos à questão da dualidade de idiomas reconhecida à Quebec, recomenda-se verificar ALAIN-G. GAGNON, Quebec y el Federalismo Canadiense, Ob. cit., pp. 165171. Num ensaio generalista sobre as consequências do idioma na sedimentação do pacto federativo, ver RONALD L. WATTS, New Federations: Experiments in the Commonwealth, London, Oxford University Press, 1966, pp. 233-236.

${ }^{421}$ A experiência alemã de levar adiante, por meio de políticas tributárias e financeiras, a equalização das disparidades regionais entre a parte oriental e a parte ocidental daquele Estado reunificado nos anos 90 é tratada por HANS-PETER SCHNEIDER, German Unification and the Federal System: The Challenge of Reform, in Recasting German Federalism: The Legacies of Unification, Charlie Jeffery (ed.), Ob. cit., pp. 72-74; e também por WolfGANG RENZSCH, German Federalism under the Challange of European Integration and Germany Unity, in A Federação em Perspectiva: Ensaios Selecionados, Ob. cit., pp. $42-44$.

${ }_{422}$ Em igual direção, Aliomar BALEEIRO, nos discursos da Assembleia Nacional Constituinte que resultou na Constituição Federal de 1946, já avalizava que as injustiças pujantes no Estado nacional poderiam ser corrigidas pela letra da Constituição, especialmente a partir de modificações expressivas no sistema tributário nacional, mas, para tanto, seria imprescindível estabelecer institutos que estampassem conteúdos práticos viabilizadores de melhorarias na vida do povo em geral, Cf. ora in OCtaCiano Nogueira, Doutrina Constitucional Brasileira (Constituição de 1946), vol. 1, Brasília, Senado Federal, 2006, p. 128. 
fatores de índole política expressivos nos anos iniciais da experiência federativa impediram, que o desenvolvimento e o progresso atingissem igualmente todos os entes. $\mathrm{O}$ caráter instrumental e corretivo conferido ao federalismo assimétrico é de todo pertinente na tentativa de vencer as barreiras formadas ao longo dos tempos e que ainda, na atualidade, impedem o desenvolvimento global e integrado do conjunto de unidades políticas integrantes do país.

A tese da assimetria federativa denota, como se percebe com claridade, a louvável preocupação em evitar que o Estado federal seja apenas uma promessa vazia de progresso político e de democratização do poder ${ }^{423}$. O pacto cimentado entre as partes precisa constituir-se em exequível compromisso de compatibilização dos desníveis regionais, assumindo a feição de instrumento para a superação dos fatores que atravancam o desenvolvimento nacional pleno e integrado. A busca de aproximação dos entes federados por meio da institucionalização de um operativo sistema de funcionamento da Federação, tal qual sugestiona o federalismo assimétrico, jamais poderá percorrer trajetos contrários aos valores que informam sua própria razão de ser.

Essas variadas ponderações sobre as possibilidades de utilizar os mecanismos assimétricos para acomodar as disparidades regionais demonstram ser de todo interessante no Brasil, sobretudo quando é lembrado que nossos sucessivos textos constitucionais não destinaram pormenorizada atenção ao cuidado das implicações negativas que se originam da patente diversidade territorial que marca o país. Nesse diapasão, a título exemplificativo, enuncia ANNA CÂNDIDA DA CUNHA FERRAZ que "as competências estabelecidas na Constituição não levam em conta essas distinções. Na verdade, dá-se, portanto, um tratamento igual em termos de repartição de competências. O mesmo se pode dizer no tocante à repartição de receitas tributárias. Todos os Estados, independentemente do grau de riqueza e de desenvolvimento de suas economias, são dotados de tratamento igualitário na partilha das receitas tributárias. A simetria no federalismo brasileiro pode ser verificada, justamente, pela análise da repartição tributária" ${ }^{424}$.

Não é costumeiro ter, entre as disposições constitucionais, institutos jurídicos que tratem essencialmente da correção das disparidades regionais que prejudicam a máxima

\footnotetext{
${ }^{423}$ No que tange aos inconvenientes da centralização, modalidade de exercício do poder político severamente combatida durante a campanha federalista no Império, é interessante fazer referência à enfática defesa do regime federativo empreendida por A. C. TAVARES BASTOS, no ano de 1870, quando foi publicada a aclamada obra "A Província" (Cf. Ob. cit., pp. 35-36). Sobre as desvantagens advindas dos regimes centralizadores, verificar também MARCELo DUARTE, Justiça Social e Federação, Ob. cit., pp. 13-14.

${ }^{424}$ Federalismo Simétrico e Federalismo Assimétrico. O Ajuste da Distribuição de Competências e de Recursos entre União, Estados e Municípios em Face de Vicissitudes de um Estado Moderno, in 10 anos de Constituição, IBDC (Instituto Brasileiro de Direito Constitucional) (coord.), Ob. cit., p. 53.
} 
eficiência governamental e ainda impedem a consolidação de um pacto federativo mais coeso e habilitado a permitir a superação dessas desigualdades. A não ser que sejam implementados ajustes cooperativos que coloquem os entes autônomos em forte sintonia em relação à proposta de atuação conjunta e integrada para diminuir os desníveis regionais e, com isso, fortalecer a Federação em sua integralidade, certamente será impossível alcançar tal objeto apenas por meio da ação fragmentada das unidades federativas. Sem a soma dos esforços do conjunto federativo, não há, em absoluto, como vencer o terrível quadro de desigualdades formado ao longo de nossa experiência de Federação, mormente porque, como é sabido, geralmente houve, no âmbito do governo federal, predomínio de interesses de algumas regiões em detrimento de outras.

Como é de fácil indução, caso os entes fiquem completamente soltos para que cada qual atue na promoção de seus interesses próprios, não haverá como proporcionar a todo o Estado brasileiro benefícios relevantes mediante a manipulação dos esquemas federativos de descentralização política consignados em nossa Carta Maior. É bastante provável que a ação isolada das partes acabe ocasionando a acentuação das disparidades territoriais já existentes, haja vista que determinados entes que possuem posições privilegiadas sempre se valem desse dado para, ainda que de forma transversa, embaraçar a atuação dos demais, em especial aquelas unidades já fragilizadas pela diversidade e que não tiveram suas necessidades particulares satisfatoriamente atendidas pelo constituinte nacional.

Em que pese a inafastável importância que o federalismo assimétrico demonstra ter para a equalização das diferenças entre as regiões e, sobretudo, para assegurar condições de vida equânimes para a população do país, uma relevante observação precisa ser feita. Deve-se cuidar para que, sob o pretexto de criar mecanismos jurídicos para acomodação da diversidade, essa proposição teórica não se desvirtue e acabe sendo empregada como estratagema para esconder odiosas intenções de negarem-se ainda mais nossas múltiplas realidades regionais, ou ainda para que se sobreponha o poder decisório de entes federados específicos ante os demais integrantes da Federação. Essa advertência é oportuna porque, conforme grifa SÉRGIO RESENDE DE BARROS, é "o constitucionalismo brasileiro um súdito fiel do legalismo" $" 425$, e, como tal, pode ser que capítulos passados de nossa história voltem a se repetir sob o pretexto da superação das desigualdades regionais, a exemplo do

425 Contribuição Dialética para o Constitucionalismo, Campinas, Millennium, 2008, p. 138. Para a compreensão das diferenças entre o Estado de Direito e o Estado de Legalidade, consultar R. CARRÉ DE Malberg, Teoría General del Estado, México, Facultad de Derecho/Unam e Fondo de Cultura Económica, 2001, pp. 449-454. 
federalismo de integração, defendido com veemência pelo governo militar na segunda metade do século XX.

Em verdade, diante da utilização incoerente e não-planejada da assimetria, inexistem tradições institucionais suficientemente seguras para impedir a desfiguração do federalismo brasileiro. Esse é um risco que se potencializa caso o federalismo assimétrico venha a ser empregado de forma mais acentuada e errônea, com o intento de atender desígnios de lideranças políticas regionais que ainda remanescem no país como herdeiras das oligarquias estaduais que monopolizaram a política na República Velha. Foram exatamente esses grupos que, nos primórdios de nossa experiência federativa, definiram as direções tomadas pelo Estado federal no país, provocando o recrudescimento das desigualdades verificadas no plano territorial, mormente porque defenderam os interesses que encabeçavam com pouca ou nenhuma preocupação com a integridade do todo.

Contaminado por tais circunstâncias, nossos incipientes laços federativos, em vez de patrocinarem a progressiva interação entre as esferas governamentais, transformaram-se num verdadeiro cabo de guerra entre o governo federal e os Estados ${ }^{426}$. Enquanto a Federação se ocupava em tranquilizar a convivência entre o poder central e os poderes estaduais, esses tiveram suas diferenças factuais agravadas, pois não havia um sedimentado projeto de desenvolvimento nacional. Foi a pacificação dos ânimos estaduais e a consequente tomada de rédeas pela União na condução da vida política do Estado brasileiro que ocasionaram o surgimento da consciência de que fórmulas jurídicas de compensação desses desníveis seriam imprescindíveis para que o país pudesse alcançar níveis ótimos de crescimento e conseguisse estabelecer uma convivência menos conflituosa entre as partes federadas.

Do exposto até o momento, chega-se a uma conclusão contundente: no Brasil, a operacionalização dos institutos relacionados ao federalismo assimétrico exige que se revitalize o conceito de cooperação intergovernamental, de modo que as relações estabelecidas entre os entes federados deverão estar adequadas aos condicionantes característicos dessa concepção de Estado federal. É possível visualizar que a Assembleia Nacional Constituinte de 1987-1988, não obstante ter deixado de adotar destacadamente institutos característicos da denominada assimetria estrutural, consignou, nos preceitos constitucionais, disposições tendentes a permitir que interações entre os entes federados

${ }^{426}$ Cf. Luiz FeliPe D’Avila, A Federação Brasileira, in Por uma Nova Federação, Ob. cit., pp. 57-58. 
fossem empregadas na missão de corrigir clivagens territoriais comprometedoras da unidade do conjunto.

É interessante pontuar também que o solidarismo impregnado ao Estado federal brasileiro apenas terá condições de ser efetivamente concretizado se o federalismo cooperativo, hoje praticado, vier a ser executado em conformidade com os valores e os comandos informadores da assimetria ${ }^{427}$. Por certo, o objetivo fundamental da República Federativa do Brasil, consagrado na parte final do inciso III, do artigo $3^{\circ}$, da Constituição vigente $^{428}$, ao preceituar uma ordem para que os poderes constituídos atuem para reduzir as desigualdades sociais e regionais, pugna pela aceitabilidade, no contexto da Federação, das acomodações jurídico-institucionais inerentes à assimetria.

Vislumbra-se, nesse dispositivo, inegável compromisso atribuído ao Estado nacional para que técnicas e teorias que se prestem a diminuir os problemáticos contrastes entre nossas regiões sejam utilizadas, desde que mantidos os valores irredutíveis da ideia federativa. Frente a esse vetor normativo, maior razão há para que seja aplicada a assimetria, já que a formulação busca, em essência, estabelecer a unidade por meio da coerente preservação das diversidades, mesmo que, para que isso aconteça, seja preciso realizar ajustes diferenciadores, a fim de possibilitar o estabelecimento da igualdade substancial entre os entes do Estado.

Apenas mediante o emprego adequado de recursos e técnicas de engenharia constitucional disponibilizados pela própria Constituição - e pelo constitucionalismo comparado - é que haverá possibilidades razoáveis e viáveis para fazer com que a Federação brasileira, mesmo marcada por drásticas diferenças regionais, possa se tornar um concerto federativo em que a presença de heterogeneidades não simbolize a entrega ao descaso governamental e a certeza de fracasso econômico em virtude da frustração de qualquer ímpeto desenvolvimentista deflagrado pelas unidades federativas. Nessa toada, antecipa-se que foco do próximo capítulo está mirado na apreciação das possibilidades de

\footnotetext{
${ }^{427}$ TÉRCIO SAMPAIO FERRAZ JUNIOR presta esclarecimentos preciosos sobre a corporificação do postulado do solidarismo no Estado federal. Afirma o autor que "o federalismo solidário exige, [...] como condição de efetividade, a cooperação entre os entes federados, tanto no sentido vertical quanto horizontal. Esta cooperação, embora à primeira vista faça pensar numa espécie de contrato federado, a presidir as relações entre as unidades, tem um outro fundamento. Na verdade, no contexto do federalismo solidário, ela não tem uma natureza contratual. Isto porque as relações interindividuais entre as entidades que compõem a federação, cujo objetivo deve ser o fomento das finalidades comuns, ainda que tenham a aparência de vinculações contratuais, com o estabelecimento de direitos e deveres em face de conteúdos específicos, têm um sentido jurídico-político que as transcende", Ob. cit., p. 7.

428 "Art. $3^{\circ}$. Constituem objetivos fundamentais da República Federativa do Brasil: [...]

III - erradicar a pobreza e a marginalização e reduzir as desigualdades sociais e regionais".
} 
exploração da assimetria no federalismo nacional, a partir da apreciação dos comandos normativos plasmados na Lei Fundamental da República vigente. 


\section{O ASSENTO CONSTITUCIONAL DA ASSIMETRIA NO ESTADO FEDERAL BRASILEIRO}

"[...] se para existir o federalismo exige, em sua essência, a
simetria, isto é, tratamento de igualdade aos entes
federados; para subsistir, ele impõe uma assimetria, que
implica tratamento constitucional desigual apto a corrigir as
desigualdades". JANICE HELENA FERRERI MORBIDELlit ${ }^{429}$

\section{V.1. Federalismo Brasileiro e Redução das Desigualdades Regionais}

A partir da análise dos pontos de destaque ligados à instauração e à consolidação do Estado federal brasileiro, uma convicção, invariavelmente, sempre será formada: a certeza de que, no curso dos anos que sucederam a proclamação da República, o peso da herança histórica e o projeto de Estado idealizado pelas elites regionais - voltado inicialmente apenas para parte do país - apresentam-se como poderosos obstáculos da racional e equânime distribuição do poder político-econômico. Durante o desenvolvimento de nosso constitucionalismo, assistiu-se, então, ao insistente atravancamento da pretensão de construir-se um Estado territorialmente composto que conseguisse congregar indicadores regionais e sociais menos desiguais, e, ao mesmo tempo, tivesse aptidão para responder às inúmeras demandas requeridas por suas partes federadas, dispostas em uma variedade notadamente problemática ${ }^{430}$.

Esse importante dado não passou despercebido nos discursos realizados nos domínios da atual Assembleia Nacional Constituinte, o que retrata a preocupação dos construtores do Estado em atender - e, principalmente, remediar - as indesejadas consequências oriundas da inconstância fatual verificada entre as regiões brasileiras. Já na instalação da Constituinte de 1987-1988, era sabido que uma nova conformação jurídicoinstitucional teria de ser aposta ao pacto federativo, caso contrário os pontos de tensão, repetidos com frequência ao longo dos períodos anteriores, persistiriam desprovidos de recursos jurídicos suficientemente habilitados ao seu devido tratamento. Era preciso forjar um pacto federativo que fosse, no mínimo, consciente acerca da necessidade de cuidar das disparidades regionais que fragilizam o desenvolvimento completo do país.

${ }^{429}$ Um Novo Pacto Federativo para o Brasil, Ob. cit., p. 240.

${ }^{430}$ Cf. TAnia Bacelar De ARaúJo, Desenvolvimento Regional: a Descentralização Valorizaria a Diversidade, in Democracia, Descentralização e Desenvolvimento: Brasil e Espanha, Sonia Fleury (org.), Rio de Janeiro, FGV, 2006, p. 373. 
Nesse ambiente de declarada preocupação em exterminar os complicados aspectos de desajuste enfrentados pelo Estado federal no país, a superação de estruturas oligárquicas de manipulação da política, do mesmo modo que a consagração de instrumentos de cooperação intergovernamental entre as unidades federadas, foi assunto permanentemente discutido. A propósito, com base em primoroso estudo sobre as diversas etapas do trabalho desenvolvido pela Assembleia Constituinte, Fernanda Dias Menezes de Almeida aponta que, no que tange ao sistema de repartição de competências, restou vitoriosa a posição "favorável à modificação da estrutura federativa no sentido de uma descentralização maior que levasse à recuperação das autonomias periféricas" ${ }^{\text {"31 }}$.

E, para o alcance desse elevado objetivo, fez-se a opção pela fórmula de descentralização gradativa, arquitetada mediante a ordenação de um conjunto de competências legislativas e de competências comuns partilhadas entre o poder central e as esferas estaduais e municipais ${ }^{432}$. Ao que tudo indica, o constituinte originário enxergou, na cooperação e no solidarismo, a chave para a correção das distorções e dos demais aspectos que desvirtuavam o funcionamento de nosso Estado federal. Em igual sentido, ANNA CÂNDIDA DA CUNHA FERRAZ observa que o "princípio da solidariedade visa à sobrevivência do Estado Federal e, do ponto de vista do tratamento constitucional das entidades federativas, propõe uma assimetria entre elas, diferenciando-as. Procurará resolver as necessidades dos Estados, que não são idênticas" ${ }^{\text {433. }}$.

Tal constatação atesta a indispensabilidade de o federalismo nacional ser estudado e apreciado em sintonia com as características e os postulados informadores da atuação governamental conjunta e interdependente. Orientação contrária poderia ocasionar o eventual esquecimento de sinais indeléveis do atual regime federativo, o que, por conseguinte, seria bastante prejudicial a qualquer investigação realizada. Por óbvio, quando se pensa no predicado assimétrico atribuído ao Estado federal brasileiro não há de ser diferente, pois será principalmente por meio da cooperação desenvolvida entre as partes do universo federativo que a assimetria aparecerá com frequência.

Com efeito, a intenção de superar as desigualdades regionais foi tema corrente na Assembleia Nacional Constituinte, sendo que tal compromisso pode ser ilustrado por meio do paradigmático pronunciamento realizado, na 79 Sessão Plenária daquela Assembleia,

\footnotetext{
431 Competências na Constituição de 1988, Ob. cit., p. 49.

${ }^{432} \mathrm{Cf}$. Idem, ibidem.

433 Federalismo Simétrico e Federalismo Assimétrico. O Ajuste da Distribuição de Competências e de Recursos entre União, Estados e Municípios em Face de Vicissitudes de um Estado Moderno, in 10 anos de Constituição, Ob. cit., p. 52.
} 
pelo constituinte UBIRATAN AGUIAR. Na ocasião, ficou registrada a justificada preocupação em evitar que o texto constitucional em elaboração permitisse a padronização do tratamento dispensado pela União aos Estados-membros, conforme se depreende do seguinte excerto: "Defendemos uma ampla reforma tributária que leve principalmente em conta o princípio da diferenciação. Certo, nós todos concordamos que nosso País é um imenso continente. Mas não podemos ainda partilhar o orgulho dos compêndios de Geografia ou dos anúncios para atrair os turistas: porque esse continente continua a ser tratado pelo Poder Central como se fosse constituído por regiões idênticas, como se nos oferecesse a paisagem repetitiva e sem atrativos da planície uniformizada; como se o País fosse uma realidade cultural única, com os mesmos problemas econômicos e sociais, os mesmos recursos financeiros para resolvê-los" 434 .

O referido membro da Constituinte certificou ainda que, em relação à divisão político-territorial do Estado, existia um sério "problema de justiça, um problema moral, um problema de solidariedade social que nos obriga a atentar para a necessidade de diferenciação quando tratamos dos critérios que irão orientar nossas reformas, nossas mudanças: quem tem mais, deveria poder contentar-se com menos; quem tem menos deveria poder receber mais, pois, sem esses princípios tão comuns e tão simples que têm norteado a aplicação da justiça, não chegaremos a construir um país mais justo e mais humano"435. De fato, no âmbito das discussões desenvolvidas, esta não foi a única manifestação que denotou preocupação com a diversidade, até então, nunca celebrada pela Federação brasileira.

$\mathrm{Na}$ mesma quadra, apesar de não ser enunciada explicitamente, a tese do federalismo assimétrico é identificável na argumentação desenvolvida pelo então Ministro do Interior, JoAquim Francisco CAVALCANTI, em painel realizado no dia 5 de maio de 1987 junto à Assembleia Constituinte, destacando aspectos que traduzem com fidelidade algumas ideias substanciais relacionadas à conformação assimétrica do Estado federal. O então Ministro de Estado grifou que, "no momento da elaboração da nova Constituição, devemos tocar profundamente nesses temas que definirão o futuro mapa político do País. Essa questão da redivisão territorial se configura, efetivamente, como questão da maior importância. Devemos observar problemas como o desenvolvimento regional, as disparidades regionais de renda, a necessidade de taxas de crescimento diferenciadas, para

\footnotetext{
${ }^{434}$ Diário da Assembleia Nacional Constituinte, Atas de Plenário, Ata da $79^{a}$ Sessão da Assembleia Nacional Constituinte, 10 de junho de 1987, Brasília, Senado Federal, Centro Gráfico, 1987, p. 211.

${ }^{435}$ Idem, ibidem.
} 
que possamos vencer o fosso do subdesenvolvimento de determinadas regiões, ou mesmo equilibrar o crescimento de determinadas regiões, aumentando sua taxa de crescimento e equipará-las com outras regiões [...]. Tudo isso poderá ser sedimentado na norma constitucional" ${ }^{\prime 436}$.

Esses apontamentos permitem que se chegue à convicção de que os regimes federativos consagrados e operados sob o pálio das Constituições anteriores ostentavam, com maior ou menor intensidade, a condição de fomentadores daquelas heterogeneidades complicadoras da coesão e da harmonia do conjunto estatal. Além disso, durante os trabalhos de confecção do novo texto constitucional, ficou evidenciado o inegável conteúdo compromissório dos discursos empreendidos ${ }^{437}$, e isso está claramente refletido nas normas positivadas na Lei Fundamental. Transparece, nesse ponto, a vontade do constituinte de fazer de sua obra jurídica um eficiente instrumento de transformação da realidade brasileira, de forma que essa orientação deve hoje servir como insubstituível recurso para nortear a aplicação dos mandamentos constitucionais em vigor.

O destacado valor a ser atribuído às referências aos textos e aos demais registros produzidos durante os trabalhos de elaboração da Constituição é realçado pela advertência feita por CARLOS MAXIMILIANO atestando que, em hermenêutica constitucional, "é de rigor o recurso aos Anais e a outros documentos contemporâneos, a fim de apurar qual era, na época da Constituinte, a significação verdadeira e geralmente aceita dos termos técnicos encontrados no texto" ${ }^{\text {438. }}$. Ao se admitir também que o sucesso dos arranjos federais depende de um desenho cuidadoso e da vontade política de melhorar o funcionamento

\footnotetext{
${ }^{436}$ Diário da Assembleia Nacional Constituinte (Suplemento), Subcomissão dos Estados, Ata da $11^{a}$ Reunião Ordinária ( $7^{a}$ Reunião de Audiência Pública), Brasília, Senado Federal, Centro Gráfico, 1987, pp. 115-116. Merece também ser lembrada aqui a contribuição prestada pela ASSOCIAÇão DOS FUNCIONÁRIOS DO BANCO NORDESTE (AFBNB), que apresentou à Assembleia, por intermédio de seu Vice-Presidente, MANOEL OsóRIO DE LiMA VIANA, o Projeto de Emenda Popular $n^{\circ} 70$, cuja redação retrata claramente o objetivo de se garantir um desenvolvimento econômico e social mais equilibrado entre as regiões brasileiras, bem como resgatar o sistema de planejamento nacional e regional, sendo interessante registrar que do artigo $1^{\circ}$ da referida propositura extrai-se o seguinte teor: "As regiões cujas condições sociais e econômicas apresentarem disparidades de desenvolvimento em relação às suas congêneres receberão tratamento diferenciado e prioritário por parte da União" (Assembleia Nacional Constituinte, Ata das Comissões, Comissão de Sistematização, Ata da $17^{a}$ Reunião Ordinária, 3 de setembro de 1988, Brasília, Senado Federal, Centro Gráfico, 1988, p. 538).

${ }^{437}$ Esclarece J. J. GOMES CANOTILHO que a Constituição compromissória é "o produto do 'pacto' entre forças políticas e sociais. Através da 'barganha' e de 'argumentação', de 'convergências' e 'diferenças', de cooperação na deliberação mesmo em caso de desacordos persistentes, foi possível chegar, no procedimento constituinte, a um compromisso constitucional ou, se preferirmos, a vários 'compromissos constitucionais'. [...] Globalmente considerados, os compromissos constitucionais possibilitam um projeto constitucional que tem servido para resolver razoavelmente os problemas suscitados pelo pluralismo político, pela complexidade social e pela democracia conflitual”, Direito Constitucional e Teoria da Constituição, $7^{\mathrm{a}}$ ed., Coimbra, Almedina, 2003, pp. 218-219.

${ }^{438}$ Hermenêutica e Aplicação do Direito, $19^{\mathrm{a}}$ ed., Rio de Janeiro, Forense, 2009, p. 253.
} 
democrático do sistema ${ }^{439}$, aflora a evidência de que tal vontade não faltou durante as atividades constituintes de 1987 e 1988. Daí porque, no que respeita à interpretação dos dispositivos constitucionais que disciplinam nosso atual regime federativo, sempre será preciso buscar o sentido que melhor se aproxime da ordem de conciliar as diferenças regionais e ainda reforçar as lealdades nacionais, uma vez que essas representam os escopos do constituinte.

É com fundamento nesses dados que se afirma ter o federalismo pátrio atingido sua fase de amadurecimento institucional na Constituição vigente. Conforme anota RAUL MACHADO HORTA, isso aconteceu não apenas porque houve o aprimoramento do sistema de repartição de competências, mas principalmente por ter a atual Lei Maior previsto instrumentos de cooperação no plano financeiro e tributário, bem como no que respeita às relações intergovernamentais ${ }^{440}$. Tamanho esforço objetivou, por certo, proporcionar a obtenção do equilíbrio de desenvolvimento e do bem-estar entre as diversas unidades regionais, o que, noutra leitura, confirma a vontade irrestrita de que fosse selado um pacto federativo mais ajustado aos parâmetros e às necessidades nacionais.

Desse modo, chega-se ao convencimento de que, em virtude de a positivação realizada na Carta Política de 1988 ter primado pelo estabelecimento de um complexo sistema de ajuda recíproca entre as unidades federadas, atribui-se ao adequado funcionamento desse arcabouço jurídico-institucional a tarefa de concretizar a promessa feita com o objetivo fundamental de reduzir as desigualdades que tomam conta das variadas regiões (art. $3^{\circ}$, inciso III, da Constituição Federal) ${ }^{441}$. Grife-se, por oportuno, que a Carta Constitucional de 1988 bem quis romper com a tradição isolacionista, entretanto ainda não conseguiu

439 PNUD (Programa das NaÇões Unidas PaRa o Desenvolvimento), Relatório do Desenvolvimento Humano 2004: Liberdade Cultural num Mundo Diversificado, Ob. cit., p. 52.

${ }^{440}$ Cf. Direito Constitucional, Ob. cit., p. 497.

${ }^{441}$ No que concerne ao significado a ser conferido às prescrições normativas que abrem a composição textual do Pacto Republicano de 1988, Gustavo TEPEDINo apresenta interessante reflexão, na qual defende uma posição axiológica de destaque aos princípios fundamentais da República. Considera que "o constituinte, não satisfeito em fixar normas gerais em cada capítulo da Constituição, deu-se ao trabalho de estabelecer regras precedentes (até mesmo do ponto de vista da localização topográfica) a todas as outras, que definem a tábua de valores do ordenamento jurídico brasileiro. Tais normas constitucionais, em particular aquelas dispostas nos arts. $1^{\circ}$ a $4^{\circ}$, são os preceitos fundamentais da ordem jurídica e, portanto, as mais importantes do ponto de vista interpretativo, a menos que se quisesse atribuir ao constituinte o papel de dispor palavras inúteis, ou ociosas - o que seria tecnicamente absurdo". E complementa: "Por que teria o constituinte utilizado a técnica dos princípios fundamentais? Por que teria anteposto aos princípios de cada capítulo os do art. $1^{\circ}$ ao $4^{\circ}, \mathrm{CF}$ ? Teria sido exercício de mera retórica, visando impressionar os eventuais leitores da Constituição? E ao intérprete, seria consentido considerar como palavras vazias o texto normativo? Não, não e não. Cuida-se de normas jurídicas, das quais decorre o impostergável dever do Estado, insculpido no art. $3^{\circ}$, inciso III, CF, em relação à justiça distributiva, à erradicação da pobreza e à diminuição das desigualdades sociais e regionais", Temas de Direito Civil, $3^{\mathrm{a}}$ ed., Rio de Janeiro, Renovar, 2004, p. 227 e pp. 230-231. Na mesma direção, Elcias Ferreira Da Costa, Comentários Breves à Constituição Federal, Porto Alegre, Sergio Antonio Fabris Editor, 1989, p. 24. 
equacionar soluções completas que possibilitem a realização dessa significativa $\operatorname{proposta}^{442}$, e é essa importante constatação que faz nutrir a confiança de que os mecanismos ligados ao federalismo assimétrico são as ferramentas mais vocacionadas para construir o desejado quadro de integração harmônica e operativa entre os diversos entes.

\section{V.2. O Predomínio das Assimetrias Relacionais na Atual Configuração da Federação Brasileira}

Convergem os estudiosos do regime federativo em atestar a relação de causalidade que há entre a intensificação das práticas de cooperação intergovernamental e a afirmação institucional do federalismo assimétrico. Embora se identifique essa forte tendência entre aqueles que se dedicam ao estudo da Federação, deve-se render, aqui, tributo à cognição de GILBERTO BERCOVICI acerca do abrigo da assimetria no Estado federal brasileiro. Tal autor abre franca contrariedade com a orientação adotada pela maior parte dos estudiosos do fenômeno federativo no país, na medida em que, peremptoriamente, nega qualquer espécie de cruzamento entre consagração de assimetrias e o consequente aprimoramento do federalismo cooperativo.

Segundo considera, “o federalismo assimétrico [...] fundamenta-se na desigualdade jurídica e de competências entre as unidades federadas, mesmo que do mesmo nível. Tratase de uma forma de organização federal contraposta ao federalismo homogeneizador do Estado Social, fundado no princípio da solidariedade" ${ }^{\text {443 }}$. E, por isso, enfatiza não acreditar "que a idéia do federalismo assimétrico, ora em voga, possa ser de grande valia para a discussão de nossa problemática federal, cujo problema fundamental é justamente a necessidade de homogeneização sócio-econômica dos entes federados, tendo em vista o objetivo nacional de diminuição das desigualdades regionais" ${ }^{\text {444 }}$. Frente a essa conclusão, há que se registrar que o aludido entendimento, embora notadamente respeitável, mostra-se contaminado por uma análise fragmentada e parcial do tema em questão, haja vista que deixa de considerar todas as formas de manifestação dos institutos de compatibilização da diversidade territorial inerentes à assimetria federativa.

Visualiza-se, assim, nas reflexões de BERCOVICI evidente propensão a reduzir o federalismo assimétrico somente ao campo das assimetrias estruturais, rechaçando-se por

\footnotetext{
${ }^{442}$ Cf. Alessandra Silveira, Ob. cit., p. 109.

${ }^{443}$ Desigualdades Regionais, Estado e Constituição, Ob. cit., p. 168.

${ }^{444}$ Idem, ibidem.
} 
completo a empregabilidade dessa teoria na modalidade relacional. Embora seja acertado analisar o Estado federal assimétrico sob a ótica das competências diversificadas previstas em prol das unidades federadas situadas num mesmo nível governamental, a materialização da assimetria não fica adstrita unicamente a esse ponto. Por certo, a configuração assimétrica de uma Federação ultrapassa a repartição das competências, ingressando na seara dos desdobramentos derivados do exercício do autogoverno, assegurado a cada um dos entes federados, o que determina a apreciação dos múltiplos modos de interação realizados pelos integrantes do concerto federativo.

Sufragar o posicionamento externado pelo referido estudioso significaria limitar o federalismo assimétrico a um universo diminuto. Abandonar-se-ia, equivocadamente, a possibilidade de apreciar a assimetria que surge da ampla teia de relacionamentos estabelecida entre os muitos órgãos que compõem o Estado federal. Tal posição iria ainda impedir que se apreciasse criticamente um dos aspectos de famigerado relevo no federalismo: a aposta na intensa cooperação entre seus entes para superar problemas derivados da diversidade. A fixação de competências constitucionais é, sem dúvida, ponto de reconhecida significância de todo regime federativo, entretanto, o federalismo, como fenômeno político-jurídico, abarca dimensões muito maiores que isso.

As relações formadas entre os entes da Federação representam hoje instrumento de indubitável expressividade na concretização dos objetivos buscados pelos Estados que se valem do federalismo para fins de estender a descentralização política a todas as regiões que o integram. A soma de esforços intergovernamentais, em geral, se executada dentro de parâmetros devidos, acabam ensejando o aparecimento de incomuns e eficientes possibilidades de contornar as disparidades impregnadas ao contexto federativo. Atuam, portanto, como valioso recurso de engenharia constitucional voltado a equacionar as diferenças regionais e acomodar a problemática diversidade em Estados compostos acentuadamente heterogêneos.

No Brasil, consoante conclui DIRCÊO TORRECILLAS RAMOS, incumbe à cooperação federativa a elevada missão, prevista como objetivo inafastável do Estado, de atenuar as complicadas disparidades formadas em todo o território nacional. Pontua ele que a fórmula ideal do federalismo está em conseguir obter "equilíbrio entre tarefas e recursos. No Estado federal cada ente recebe tarefas e recursos para a execução das mesmas. Quando ocorre o desequilíbrio entre as obrigações e os meios financeiros, chegamos ao que se convencionou chamar de crise de sobrecarga. Verificamos que uma das razões para o sucesso do federalismo é o balanceamento geográfico, do tamanho do Estado, da riqueza, 
da população. No Brasil há uma disparidade em relação a esses requisitos, com acentuada desigualdade. A solução encontrada, não só entre nós, mas já preocupando outros países como a Suíça, Espanha, Estados Unidos, é a busca do equilíbrio, a cooperação, através de: a) divisões regionais, por grupos de Estados; b) divisão de tributos; c) criação de incentivos fiscais e de outras modalidades e a redistribuição de receitas" ${ }^{245}$.

Em abono da tese de que é impossível dissociar a assimetria do universo do federalismo por cooperação, PETER PERNTHALER esclarece que o federalismo assimétrico pode ser corporificado de inúmeras formas, sempre a depender das necessidades e das conveniências apresentadas pelos Estados que dele utilizam. No geral, ao ser colocado em aspectos jurídico-normativos, o caráter assimétrico de uma Federação assume as vestes de institutos particulares de diferenciação regional ou funcional sobre a base organizativa federal homogênea. Assinala também que, para terem garantias mínimas de respeitabilidade, as assimetrias deverão estar previstas em textos jurídicos (preferencialmente na Constituição), pois não é indicado deixá-las ao talante exclusivo da política $^{446}$.

Nesse compasso, PernTHAler complementa que, dentre as muitas modalidades de assunção do caráter assimétrico por Estados compostos, algumas costumam aparecer com intensidade, são elas: a) instauração de permanente colaboração inter-regional com o objetivo de permitir a prestação consorciada de serviços públicos e o exercício de competências legislativas concorrentes; b) emprego de procedimentos específicos disponibilizados pela União em prol de Estados determinados levando-se em conta necessidades particulares destes, como é o caso, por exemplo, da delegação na atividade legislativa federal feita pelo poder central apenas para um ente federado ou para um grupo deles; c) elaboração de um sistema financeiro assimétrico que consagre e acomode satisfatoriamente aspectos como a crescente complexidade da equalização financeira; o financiamento de base extensível a todas as unidades federadas conforme critérios préestabelecidos na Constituição; a responsabilidade financeira e a criação de um fundo comum de solidariedade; d) consentimento de que, por força de motivos especiais, determinados entes autônomos estabeleçam relações com o exterior, bem como executem

445 O Federalismo Assimétrico, Ob. cit., pp. 59-60. Em específico, a questão da celebração de tratados internacionais pelas unidades subnacionais é explorada sob o prisma do Direito Comparado por ÁlvARO Chagas Castelo Branco, Paradiplomacia \& Entes Não-Centrais no Cenário Internacional, Curitiba, Juruá, 2008, pp. 63-84.

${ }^{446}$ Cf. $O$ b. cit., pp. 54-55. 
contatos regionais com seus congêneres, tomados em caráter particular no âmbito interno da Federação ${ }^{447}$.

Conforme se infere das considerações empreendidas, o fenômeno jurídico-político da assimetria abrange mais do que as competências definidas no texto constitucional, uma vez que também interfere nas relações intergovernamentais praticadas pelas unidades de Estados que adotam federalismo cooperativo. A intersecção apurada entre cooperação e assimetria é tão forte que há autores, a exemplo de ENRIQUE ÁlVAREZ CONDE, que chegam a definir assimetria como sendo "o grau de heterogeneidade decorrente do sistema de relações exercitadas entre as diversas unidades governamentais" ${ }^{" 448}$, confundindo-a com a conjunção de diferentes níveis governamentais para alcançar escopos comuns. Impossível, portanto, dissociar as interações governamentais dos aspectos estruturais que sustentam tais Federações, porque, nesses Estados, a cooperação está intrinsecamente amalgamada à arquitetura federativa $^{449}$.

$\mathrm{O}$ que, em verdade, acaba distinguindo o federalismo assimétrico do federalismo cooperativo é o fato de os entes federados não apenas apresentarem diferenças entre si em seus ordenamentos jurídicos específicos, mas, em especial, possuirem as unidades autônomas, ainda que alocadas no mesmo patamar governamental, diferentes status jurídico e variadas esferas de atuação. É evidente que, no Estado federal cooperativo, existem infinitas possibilidades de haver a diversificação desse raio de atuação das unidades autônomas, de forma que, quanto maiores os relacionamentos efetivados pelas partes do sistema federativo, mais potencializadas serão as chances de surgimento das

\footnotetext{
${ }^{447}$ Cf. Ob. cit., pp. 55-73.

448 Asimetría y Cohesión en el Estado Autonomico, in Asimetría y Cohesión en el Estado Autonómico: Jornadas sobre el Estado Autonómico: Integración y Eficacia, INAP (Instituto Nacional de Administración Pública), Ob. cit., p. 85.

449 Sobre a íntima ligação entre práticas de cooperação entre governos e as bases estruturais do Estado federal, consultar Janice Helena Ferreri, A Federação, in Por uma Nova Federação, Celso Bastos (coord.), Ob. cit., p. 34; Paulo Bonavides, A Constituição Aberta: Temas Políticos e Constitucionais da Atualidade, com ênfase no Federalismo das Regiões, Ob. cit., p. 396; e DirCÊO Torrecillas RAMOS, $O$ Federalismo Assimétrico, Ob. cit., p. 49. Em especial, vale referir-se à obra de CÁRMEN LÚCIA ANTUNES RochA, esta, ao apreciar as características naturais e jurídicas ligadas à implantação e ao posterior desenvolvimento do federalismo brasileiro, estatui que, no país, essas relações sempre estiveram arraigadas à nossa organização estatal, embora, depois de 1937, as Constituições passassem a acentuar esse dado. A autora assim define tal característica: "Note-se, aliás, que a experiência federativa brasileira não comporta a condição 'cooperativa' como se fosse um dado ou um desenho constitucional ultimado apenas em 1934. Primeiro, porque o discurso constitucional sempre previu a coexistência óbvia das entidades federadas, as quais teriam que cooperar com o poder central, pena de inexistir o federalismo neste país vastíssimo; em segundo lugar, porque, na maioria das regiões e dos Estados-membros, não se teriam condições de sobrevivência isolada ou sem a cooperação do poder central em face de condições ambientais e distanciadas dos demais em que se encontram", Ob. cit., p. 228.
} 
assimetrias. Reafirma-se, assim, a proximidade que há entre ambas as manifestações do Estado federal.

Tal conclusão é constatada com absoluta clareza na Federação brasileira, pois, aqui, a assimetria está notavelmente impregnada ao dinamismo que marca o funcionamento de nosso federalismo cooperativo. ASPÁSIA CAMARGO corrobora esse entendimento, sobretudo quando registra que "à União estão prioritariamente reservadas as funções gerais de planejamento global e de coordenação, de acompanhamento e avaliação, cujo êxito depende essencialmente da produção e do controle da informação em parceria com as unidades federadas. [...] Dentro da Federação seu papel deve ser antes de mais nada integrador, incentivador e corretivo, seja contribuindo para expandir, através da assistência técnica, a capacidade inovadora das unidades federadas e a articulação das mesmas; seja lhes assegurando justiça e equidade, graças à proteção de órgãos centrais fiscalizadores, e a políticas deliberadas de correção dos desequilíbrios regionais" ${ }^{450}$.

Na Constituição Federal brasileira de 1988, a ordem para o desenvolvimento de um federalismo solidário, materializado por meio da conjugação de aspectos de cooperação intergovernamental com os instrumentos de assimetria, está, em última análise, sacramentada no caput do art. $5^{\circ}$ ("todos são iguais perante a lei”). Expõe TÉRCIO SAMPAIO FERRAZ JÚNIOR que as organizações estatais deverão, necessariamente, garantir o direito à igualdade, o que comporta uma aspiração bem mais ampla do que a mera isonomia entre indivíduos, haja vista que essa norma alcança também as desigualdades de fato, as quais desvalorizam a existência de condições empíricas discriminantes e, por isso, exigem a equalização das possibilidades de desenvolvimento em todos os cantos do território nacional $^{451}$. Sem integral respeito à diversidade e negligenciando-se cuidado aos fatores que impedem a consecução da igualdade substancial, não haverá verdadeira observância dos objetivos fundamentais da República capitulados no art. $3^{\circ}$ da Lei Maior e estar-se-á deixando de cumprir a vontade manifestada pelo constituinte ${ }^{452}$.

Pelo que se depreende das considerações acima, a percepção de que a forma federativa de Estado deve estar sintonizada com os elevados fins a serem acatados pelos órgãos de governo indica que o assunto das desigualdades regionais precisa figurar permanentemente na pauta de interesses de todos os entes federados, inclusive daqueles que gozam de posições de prestígio no contexto federativo. Além disso, há que se firmar

\footnotetext{
${ }^{450}$ O Novo Pacto Federativo, in Revista do Serviço Público, ano 45, vol. 118, nº 1, jan./jul. 1994, p. 89.

${ }^{451}$ Cf. Ob. cit., pp. 6-7.

${ }^{452}$ Cf. Idem, p. 7.
} 
ainda o convencimento de que os dispositivos constitucionais precisam ser interpretados com vistas a fazer com que as disparidades territoriais deixem de representar elemento de desagregação da unidade estatal, o que certamente ocorrerá quando todas as unidades federadas receberem adequado tratamento jurídico e forem inseridas no conjunto apresentando condições paritárias de atuação em relação às congêneres. O federalismo assimétrico pode transformar os desníveis regionais em fonte de contínua renovação dos laços associativos do Estado federal, entretanto, para que isso aconteça, ter-se-á de imprimir ao pacto federativo a condição de principal garantidor da harmoniosa diversidade e também tê-lo como peça-chave para uma eficiente governabilidade.

Ter essas perspectivas assentadas é imprescindível para iniciar a análise, em espécie, das normas constitucionais que buscam disciplinar as desigualdades regionais na órbita do Estado brasileiro. Assim é que os dispositivos da Constituição vigente que se afinam à noção de assimetria e, por decorrência, buscam corrigir os desníveis causados pelas impactantes diferenças que tomam conta do Estado nacional serão abordados essencialmente sob o prisma jurídico, deixando-se de lado implicações políticas diversas que os mesmos podem trazer. A relevância de tal parte do trabalho constitui ponto de notável interesse não apenas para o estudo do federalismo, mas para todo o sistema constitucional, uma vez que é impossível interpretar as normas referentes à estruturação da Federação isoladamente, apartando-as dos outros institutos consagrados pelo constitucionalismo.

\section{V.3. Os Reflexos da Assimetria Federativa nas Previsões Encartadas na Constituição Federal de 1988}

No curso de nossa história federativa, as disparidades regionais levaram à formação de várias coalizões de determinados Estados contra outros, o que, decisivamente, atrapalhou e muito a cooperação entre os atores do conjunto ${ }^{453}$. A evidência de que essas desigualdades fáticas sempre atuaram como ponto de problematização do pacto federativo construído no país requer a leitura dos dispositivos consignados na atual Lei Maior com o propósito de exterminar práticas e interpretações que desprestigiam os valores democráticos - os quais, como se sabe, são promovidos pela da descentralização do poder político. De tal sorte, firma-se a convicção de que, no caso brasileiro, as assimetrias

\footnotetext{
${ }^{453}$ Cf. Fernando Luiz Abrucio e Valeriano Mendes Ferreira Costa, Ob. cit., p. 33.
} 
jurídicas precisam viabilizar a superação de tais aspectos arraigados ao contexto nacional, tal qual é o caso do privilegiado enquadramento da União em face dos entes subnacionais, ou ainda de determinados Estados-membros diante de seus congêneres.

Os inegáveis desníveis entre as partes da Federação levaram à construção de um sistema constitucional-tributário pautado na redistribuição de recursos financeiros como principal ferramenta de compensação do malogro de algumas unidades federativas. Além disso, também se acreditou que tratamentos diferenciados em benefício das regiões administrativas, o que geralmente aconteceria mediante a instituição de incentivos econômicos que beneficiassem localidades com desenvolvimento incipiente, seria uma saída razoável para esse complicado descompasso ${ }^{454}$. A cooperação federativa foi colocada como grande promessa de compatibilização da diferença, delegando-se ainda ao poder central a importante tarefa de coordenar todos os esquemas idealizados nessa seara.

Não obstante os esforços do constituinte em disciplinar os mecanismos de ajustamento da diversidade, na prática, quando esses recursos assimétricos começaram a ser utilizados, viu-se o quão difícil seria a atuação concertada dos entes. A concreta aplicação dos referidos dispositivos da Constituição mostrou ser inapropriada para uma Federação como a nossa, que pretende cultivar a coexistência amistosa de seus membros, pois o que se assistiu foi uma exacerbada centralização de poder na União. O ente nacional não só ficou encarregado de tomar as decisões de redistribuição das receitas, mas também passou a exercer, efetivamente, o comando do desenvolvimento de todas as regiões do país ${ }^{455}$, o que fez emergir, como reflexo, preocupante corrente antifederalista, que mesmo não tendo "forças para derrubar o sistema, contudo pode abalá-lo no futuro" ${ }^{456}$, segundo observa MANOEL GonÇALVES FERREIRA FILHO.

Esse quadro, por si só, justifica o amplo interesse que o federalismo assimétrico representa para aqueles que se preocupam com o correto funcionamento do Estado nacional. De fato, não se pode contrariar a convicção de que, se for institucionalizada em atenção aos condicionantes que esgarçam os vínculos federativos no país, a assimetria jurídica certamente proporcionará o fortalecimento do pacto federativo, sufocando as aspirações contrárias à Federação originadas, na maior parte das vezes, nas regiões que sofrem os efeitos diretos da desigualdade. Daí o motivo que determina a atribuição de crédito ao entendimento de que os arranjos político-jurídicos representam a fonte mais

${ }^{454}$ Cf. Manoel Gonçalves Ferreira Filho, Aspectos do Direito Constitucional Contemporâneo, Ob. cit., p. 183.

${ }_{455}$ Cf. Idem, p. 184.

${ }^{456}$ Idem, pp. 184-185. 
segura para contornar os aspectos que dificultam a plena materialização dos elevados valores e objetivos sacramentados no texto constitucional e que, intuitivamente, dependem do sucesso da Federação para tomarem forma, a exemplo do mandamento programático de construir uma sociedade livre, justa e solidária.

Depois de cientificada a importância de considerar o federalismo assimétrico para o cumprimento da gama de competências colocada às unidades federadas e, sobretudo, para o combate aos fatores de desagregação da unidade do Estado, passa-se a analisar os dispositivos da Constituição Federal de 1988 que refletem, em diferentes intensidades, a ideia de assimetria. Será seguida, aqui, a orientação de MichaEl Burguess e Franz GRESS no sentido de que o método mais indicado para compreensão da assimetria é empregar duas frentes de trabalho: a primeira, realizada nas partes antecedentes desta dissertação, buscou uma abordagem analítica da estabilidade política em ambientes submetidos a forças desagregadoras da diversidade regional; a segunda, que será apresentada com maior ênfase a partir de agora, corresponde ao estudo de prescrições normativas que demonstram a predisposição ao acatamento dos valores que balizam os sistemas constitucionais assimétricos ${ }^{457}$. A observância dessa dupla proposição, sem dúvida, permitirá que se juntem discussões teóricas à aplicabilidade prática das mesmas, o que aumenta em muito o interesse sobre o tema aqui desenvolvido.

Desse modo, voltam-se aos mandamentos constitucionais que, em seu conteúdo, trazem a possibilidade de diferenciar os entes federados com o intutito de equalizar pontos de dissensão advindos do próprio sistema federativo. Registra DIRCÊO TORRECILLAS RAMOS que tais normas, em verdade, são "preceitos que estabelecem uma cooperação visando a diminuição das desigualdades, o desenvolvimento equilibrado, a criação de regiões. Estabelecem, além da distribuição da receita, outras formas de incentivos" ${ }^{\text {"45 }}$. Por isso é que se afirma ser a assimetria jurídica importante instrumento colocado a serviço da engenharia constitucional para permitir a obtenção de uma fórmula política sintonizada com o denominado Estado federal de equilíbrio ${ }^{459}$, o que abre a possibilidade de estabelecer-se tratamentos e disciplinas jurídicas particularizantes entre as unidades federativas, quando for preciso.

${ }^{457}$ Cf. Symmetry and Asymmetry Revisited, in Accommodating Diversity: Asymmetry in Federal States, Robert Agranoff (ed.), Ob. cit., p. 56.

458 Ob. cit., p. 175.

${ }^{459}$ ANDRÉ RAMOS TAVARES afirma que o federalismo de equilíbrio "significa a necessidade de que no federalismo se mantenha o delicado equilíbrio entre as entidades federativas. Isso pode ser alcançado pelo estabelecimento de regiões de desenvolvimento (entre os Estados) e de regiões metropolitanas (entre os municípios), concessão de benefícios, além da redistribuição de rendas. Trata-se, pois, de modalidade que se agrega às demais para reforçar as instituições federativas", Ob. cit., p. 1049. 


\section{V.3.1. Competências Constitucionais Comuns: Estudo do parágrafo único do art. 23 da Constituição Federal}

A transição do Estado liberal para o Welfare State ocasionou drásticas mudanças no modo de execução das atividades públicas, e isso, obviamente, repercutiu no sistema de repartição de competências entre as entidades federadas, encarregadas de prestar serviços à coletividade. Foram conferidas à União parcelas competenciais relevantes e funções de governo antes impensáveis, se tomados como paradigmas os postulados do convencionado federalismo dual ${ }^{460}$. Hoje, em virtude da relevância assumida pela cooperação intergovernamental, a maioria dos países de estrutura federativa dependem da coordenação dos diferentes níveis de poder para o êxito de políticas públicas, cabendo a cada Federação, com foco em suas características e demandas próprias, procurar, mediante técnicas jurídicas de compatibilização da diferença, a ajustada composição entre a imprescindível homogeneidade do todo e a pluralidade otimizada ${ }^{461}$.

Em ambientes federativos de implacáveis dissimetrias, a busca pelo equilíbrio deve representar compromisso obrigatório na idealização de estruturas ou na execução de ações estatais que congreguem os diversos níveis governamentais. Não se pode perder de vista que as unidades autônomas têm, cada qual, tarefas a serem cumpridas e, por conta disso, necessitarão de recursos para permitir a prestação de tais incumbências. O custeio dessas funções deverá ser suportado por receitas próprias ou transferências intergovernamentais, sendo que a definição do quantum a ser repassado pela União às unidades subnacionais terá de ser fixado em função de uma série de fatores, como, por exemplo, "as diferenças de população em geral e a população carente, as dimensões, as riquezas, o potencial e o esforço para arrecadar, as condições sociais e econômicas, as dificuldades de locomoção, diferenças étnicas e raciais, linguísticas, que caracterizam o federalismo 'assimétrico""462.

O cômputo dos desníveis regionais, na verdade, não deve ocorrer apenas para disciplinar a transferência de receitas federais aos Estados e aos Municípios. A Constituição Federal de 1988 abre a possibilidade de, na definição das práticas de

${ }^{460}$ Cf. CÁRMEn LúCIA ANTUNES Rocha, Ob. cit., p. 255.

${ }^{461}$ Cf. ANDREAS J. KRell, A Necessária Mudança de Foco na Implantação do Federalismo Cooperativo no Brasil: da Definição dos Competências Legislativas para o Desenho de Formas Conjuntas de Execução Administrativa, in Vinte Anos da Constituição Federal de 1988, Cláudio Pereira de Souza Neto, Daniel Sarmento e Gustavo Binenbojm (coord.), Ob. cit., pp. 644-645.

${ }_{462}$ DiRCÊO TORRECILlas RAmOS, Organização do Estado: o Estado Federal, in Constituição Federal: Avanços, Contribuições e Modificações no Processo Democrático Brasileiro, Ives Gandra Martins e Francisco Rezek (coord.), Ob. cit., p. 276. 
cooperação intergovernamental, haver a edição de lei complementar federal que ordene os entes federados a executarem as competências elencadas nos incisos do art. 23 da Lei Maior, sempre que restar configurada a necessidade de asseguar o equilíbrio do desenvolvimento e do bem-estar em âmbito nacional. A norma colocada no parágrafo único do mencionado dispositivo representa inequívoca prova de que os indesejados reflexos das diferenças regionais não podem prejudicar o desempenho do Estado como um todo, cabendo ao governo federal elaborar atos normativos infraconstitucionais que cuidem da equalização das condições verificadas nas unidades subnacionais ${ }^{463}$.

Os ensinamentos de ANNA CÂNDIDA DA CUNHA FERRAZ em defesa do princípio da solidariedade como fator de interligação das partes que integram a obra federativa reforçam essa constatação. Conforme apresenta a autora, a efetivação das metas veiculadas nos artigos do atual Pacto Republicano, especialmente nos preceitos que estabelecem os objetivos a serem buscados pelo Estado brasileiro, dependerá do acertado emprego de um instituto previsto em outro ponto do texto constitucional, qual seja, o já explicitado parágrafo único do art. 23 da Lex Mater ${ }^{464}$. Inegável, pois, que a soma de esforços intergovernamentais deverá ser o recurso mais explorado para concretizar as promessas da Constiuição no tocante ao funcionamento das estruturas e das ações governamentais vinculadas à Federação nacional idealizada em 1988.

$\mathrm{Na}$ verdade, a introdução desse preceito para induzir o funcionamento do federalismo no país retrata o desejo do constituinte de realçar a corresponsabilidade dos entes políticos na consecução de objetivos comuns para todo o Estado federal. Traduzida em termos práticos, essa opção reflete que a lógica da Constituição está calcada na crença de que as relações intergovernamentais correspondem não apenas a uma faculdade colocada às partes federadas, mas, ao contrário, importam em dever, cuja observância não poderá ser negligenciada. O federalismo pátrio demonstra, pois, estar antenado com os parâmetros que orientam os exemplos de descentralização política, no Direito Comparado, considerados exitosos, uma vez que aposta no abandono de práticas isolacionistas e coloca

463 “"Art. 23. [...]

Parágrafo único. Leis complementares fixarão normas para a cooperação entre a União e os Estados, o Distrito Federal e os Municípios, tendo em vista o equilíbrio do desenvolvimento e do bem-estar em âmbito nacional".

${ }^{464}$ Cf. ANNa CÂNDIDA Da Cunha FerRaz, Federalismo Simétrico e Federalismo Assimétrico. O Ajuste da Distribuição de Competências e de Recursos entre União, Estados e Municípios em Face de Vicissitudes de um Estado Moderno, in 10 anos de Constituição, IBDC (Instituto Brasileiro de Direito Constitucional) (coord.), Ob. cit., p. 55. 
a cooperação entre governos como o mais importante fator de promoção do desenvolvimento ${ }^{465}$.

A interpretação sistemática do mandamento constitucional insculpido no parágrafo único do art. 23 da Carta Constitucional permite que se extraia significativa ferramenta para vencer, por meio da cooperação, as dificuldades de coesão governamental e de harmonia política, constantemente potencializadas pelas desigualdades que marcam as regiões do país. Por certo, essa previsão é uma das mais contundentes evidências de que, no Brasil, o federalismo assimétrico não pode ser estranho à dogmática constitucional, cabendo compreendê-la como uma medida cuja finalidade essencial é a de "evitar choques e dispersão de recursos e esforços" ${ }^{\$ 66}$. Dessa forma, com lastro nas ideias primaciais acerca do conceito de assimetria jurídica, atesta-se a pertinência de se conferir maior atenção à possibilidade de o legislador federal reenquadrar as instituições e as práticas que caracterizam nosso Estado federal $^{467}$, para, nos moldes propugnados pelo Estado federal de equilíbrio, colocar as esferas de governo em nível de igualdade ${ }^{468}$.

A propósito, é possível vislumbrar que a edição da Emenda Constitucional n ${ }^{\circ} 53$, de 19 de dezembro de 2006, trouxe renovadas expectativas sobre a valorização da função conformadora do parágrafo único do art. 23 da Constituição Republicana vigente. A redação anterior, que previa a edição apenas de uma única lei complementar para fixar as normas de cooperação entre a União e os entes federados, foi reformada para permitir que distintas leis complementares colocassem os parâmetros de interação intergovernamental no campo das competências comuns. Consoante os termos apostos no Parecer aprovado, em 03 de maio de 2006, pela Comissão de Constituição e Justiça do Senado Federal, cuja relatoria coube ao Senador JOSÉ JORGE, tal mudança foi entendida como saudável à Federação nacional, "vez que o tempo de maturação das propostas de colaboração é diferente em cada área de atuação dos Poderes Públicos, gerando momentos distintos para fixação de seu marco institucional" ${ }^{\text {469 }}$.

Mesmo tendo consciência do elevado grau de dificuldade que, na prática, será defrontado no momento de criação dessas leis complementares, sobretudo porque as especificidades inerentes a cada um dos serviços públicos prestados exigirão extrema

${ }^{465}$ Cf. Janice Helena FerReri Morbidelli, Um Novo Pacto Federativo para o Brasil, Ob. cit., pp. 235236.

${ }^{466}$ Paulo Gustavo Gonet Branco, Organização do Estado, in Curso de Direito Constitucional, Gilmar Ferreira Mendes, Inocêncio Mártires Coelho e Paulo Gustavo Gonet Branco, Ob. cit., p. 870.

${ }^{467}$ Cf. Dircêo Torrecillas Ramos, O Federalismo Assimétrico, Ob. cit., p. 173.

${ }^{468}$ Cf. JANice Helena FerReri Morbidelli, Um Novo Pacto Federativo para o Brasil, Ob. cit., p. 236.

469 Brasil, Senado Federal, texto extraído de documento digital disponível no sítio eletrônico: www.senado.gov.br, acesso em 30/12/2009. 
sensibilidade do legislador, é imprescindível que se acredite nesse instrumento para contornar parte das tensões verificadas no pacto federativo. Nesse ponto, cabe lembrar que a hermenêutica constitucional é empreendida a partir de alguns princípios exegéticos, figurando entre tais diretivas o princípio da força normativa da Constituição, que prega a importância de "dar-se primazia às soluções hermenêuticas que, compreendendo a historicidade das estruturas constitucionais, possibilitam a 'atualização' normativa, garantindo, ao mesmo pé, a sua eficácia e permanência» ${ }^{, 40}$. Competirá, por conseguinte, ao Poder Legislativo buscar resolver os problemáticos e históricos impasses verificados na Federação nacional derivados da heterogeneidade que se recrudesce entre as unidades federadas, devendo-se, para tanto, aplicar corretas fórmulas de fomento de uma cooperação federativa afinada com os objetivos fundamentais colocados à República.

Embora alguns autores, como é o caso de UADI LAMMÊGO Bulos ${ }^{471}$ e de PINTO FERREIRA $^{472}$, não nutram grandes esperanças sobre os benefícios que podem ser obtidos pela aplicação do aludido comando jurídico-constitucional, parece que a melhor orientação a ser adotada é aquela que o interpreta à luz dos vetores axiológicos da teoria do federalismo assimétrico, o que lhe faz adquirir contornos sobressalentes e confiar nos resultados que poderão decorrer de sua aplicação precisa. Desse modo, segundo esclarece FERnANDA DiAs MENEZES DE AlMEIDA, as leis complementares cuidarão de especificar "que instrumentos de ação administrativa poderão ser utilizados para ensejar o exercício mais vantajoso das competências comuns" ${ }^{473}$, o que, em definitivo, permite ao legislador considerar com seriedade as particularidades apresentadas pelos entes federados envolvidos na execução conjunta de serviços públicos. Entre as muitas variantes que deverão ser admitidas na formação e no aperfeiçoamento de um sistema de cooperação federativa equilibrado e eficiente, por certo, devem estar as desigualdades fáticas, apuradas a partir do cotejo entre os indicadores apresentados pelos entes federados.

\footnotetext{
${ }^{470}$ J. J. Gomes CANotilho, Direito Constitucional e Teoria da Constituição, Ob. cit., p. 1226.

${ }^{471}$ Pondera Bulos que o parágrafo único do art. 23 da Constituição Federal buscou manter o ideal do federalismo cooperativo, entretanto, a intenção colimada ainda não conseguiu ser atendida, já que, "até agora, não se sabe da existência de lei complementar aludida no preceito". Consoante expõe o autor, esse dado torna a disposição focalizada em mero ideal proclamado pelo constituinte, mas que carece de regulamentação por parte do Poder Legislativo para poder vir a ter aplicação concreta (Constituição do Brasil Anotada, $7^{\mathrm{a}}$ ed., São Paulo, Saraiva, 2007, p. 565).

${ }^{472}$ Em clara demonstração de ceticismo no tocante aos efeitos práticos decorrentes do apontado mandamento constitucional, PINTO FERREIRA opina que o dispositivo apreciado, além de ser um comando puramente abstrato e programático, "repousa na crença ilusória do milagre das leis, que no caso busca, mediante cooperação entre as entidades estatais, o equilíbrio do desenvolvimento e do bem-estar no âmbito nacional" (Comentários à Constituição Brasileira, vol. 2, Arts. 22 a 53, São Paulo, Saraiva, 1990, p. 95).

${ }^{473}$ Competências na Constituição de 1988, Ob. cit., p. 118.
} 
Pelo que já foi exposto, é possível afirmar que a normatividade estampada no dispositivo em tela permitirá o sopesamento dos multifacetários aspectos de cada uma das esferas políticas envolvidas na execução dos serviços objeto de competência comum. A intenção veiculada pela Lei Maior é fazer com que se alcance uma fórmula políticojurídica por meio da qual todos os entes da Federação consigam prestar satisfatoriamente as atividades que lhes são propostas. Feitos esses apontamentos, vale recorrer, mais uma vez, ao escólio de Fernanda Dias Menezes de Almeida para exemplificar o quão importante é a edição dos atos legislativos complementares federais que estabeleçam as linhas a serem seguidas em situações de cooperação intergovernamental firmadas no Estado Federal, para a consolidação de nossas estruturas federativas idealizadas pelo poder constiuinte originário.

Elucida a autora que a criação dos referidos atos normativos complementares pela União fará com que, "levando-se em conta as reais possibilidades administrativas e orçamentárias dos diversos parceiros, não se atribua a algum deles, em nome de uma responsabilidade solidária, tarefa que não possa cumprir. Assim é que - tomando-se por hipótese os serviços de saúde - atentaria contra os princípios da razoabilidade e da proporcionalidade exigir-se de um Município sem recursos técnicos e financeiros suficientes o fornecimento à população de remédios ou tratamento médico cujo alto custo e a alta complexidade estejam além da reserva do possível" ${ }^{474}$. Da explicação apresentada, chega-se à conclusão de que, a despeito da redação ofertada pelo parágrafo único do art. 23 da Lei Maior, aparentemente, limitar a junção de esforços governamentais à consecução de objetivos nacionais, "nada impede que se faça a cooperação entre Estados, ou entre Estados e Municípios, visando ao equilíbrio e desenvolvimento e ao bem-estar em âmbito regional ou das comunidades locais $" 475$.

No que respeita às competências constitucionalmente fixadas, um aparte precisa ser feito, pontuando claramente a impropriedade de, sob os influxos do federalismo assimétrico, atribuir-se o mesmo tratamento às competências administrativas comuns e às competências legislativas concorrentes. Nos moldes ofertados pelo Pacto Fundamental de 1988, a assimetria federativa deve ser aplicada no desempenho das competências materiais comuns, ou seja, naquelas voltadas a concretizar atividades administrativas, as quais, em essência, representam a prestação de serviços públicos pelos vários governos que

\footnotetext{
${ }^{474}$ Competências na Constituição de 1988, Ob. cit., p. 118.

475 José Afonso da Silva, Comentário Contextual à Constituição, Ob. cit., p. 275.
} 
compõem a Federação ${ }^{476}$. Não obstante haver previsão insculpida no parágrafo único do art. 22, também da Constituição Federal ${ }^{477}$, estabelecendo que, em questões específicas, está a União autorizada a delegar aos Estados-membros, mediante edição de lei complementar, parte de suas competências legislativas privativas, é defeso conferir tratamento diferenciado aos entes federados que, porventura, vierem a ser os delegatários de tais competências.

Os motivos que sustentam a afirmação tirada acima podem ser sintetizados nas seguintes constatações. Em primeiro lugar, a redação do art. 23 da Constituição faz referência expressa ao fato de que as várias leis complementares que regerão a execução das competências comuns terão, obrigatoriamente, de ter como foco o equilíbrio do desenvolvimento e o bem-estar nacional, previsão inexistente no dispositivo que permite a delegação aos entes estaduais das competências privativas da União (art. 22, parágrafo único, da CF). Cabe considerar também que os serviços públicos estão submetidos ao princípio da eficiência, e isso significa que, por força dos reclamos impostos pela complexidade da vida social, tais serviços deverão ser disponibilizados à população com vistas a permitir uma melhor satisfação do bem-estar geral $^{478}$, abrindo-se, aqui, ampla possibilidade de utilização dos mecanismos de engenharia constitucional, inclusive com inovações na estrutura composta do Estado, para atender a essa principiologia.

\footnotetext{
${ }^{476}$ Nessa direção, ANDRÉ RAMOS TAVARES enfatiza que, "no âmbito da competência comum, todos os entes federativos podem atuar administrativamente. Assim, tanto a União, quanto os Estados-membros, Municípios e o Distrito Federal encontram-se aptos a realizar atividades quanto às matérias mencionadas" (Ob. cit., p. 1095). Cumpre referenciar ainda UADI LAMMÊGO BULOS, que estabelece interessante intelecção sobre o tema comentado, registrando que "o que justifica a competência comum é a descentralização de encargos em assuntos de enorme relevo para a vida do Estado federal. São matérias imprescindíveis ao funcionamento das instituições, motivo pelo qual se justifica a convocação dos entes federativos para, numa ação conjunta e unânime, arcar, zelar, proteger e resguardar as responsabilidades recíprocas de todos. A finalidade primordial da competência comum é evitar que não prevaleça uma entidade sobre a outra", Curso de Direito Constitucional, Ob. cit., p. 759.

477 “Art. 22. [...]

Parágrafo único. Lei complementar poderá autorizar os Estados a legislar sobre questões específicas das matérias relacionadas neste artigo".

${ }^{478}$ Cf. Edílson Pereira Nobre Júnior, Administração Pública e o Princípio Constitucional da Eficiência, in Revista Trimestral de Direito Público, $\mathrm{n}^{\circ}$ 44, out./dez. 2003, pp. 69-70. Sobre a delimitação dos contornos do princípio da eficiência administrativa, MARIa Sylvia ZaNella Di Pietro explica que esse comando principiológico "apresenta, na realidade, dois aspectos: pode ser considerado em relação ao modo de atuação do agente público, do qual se espera o melhor desempenho possível de suas atribuições, para lograr os melhores resultados; e em relação ao modo de organizar, estruturar, disciplinar a Administração Pública, também com o mesmo objetivo de alcançar os melhores resultados na prestação do serviço público. Trata-se de ideia muito presente entre os objetivos da Reforma do Estado. [...] É com esse objetivo que estão sendo idealizados institutos, como os contratos de gestão, as agências autônomas, as organizações sociais e tantas outras inovações com que se depara o administrador a todo momento" (Direito Administrativo, $21^{\mathrm{a}} \mathrm{ed}$., São Paulo, Atlas, 2008, p. 79); e a conclusão que se obtém é a de que as assimetrias federativas, ao serem introduzidas no sistema constitucional nacional, terão de mirar o incremento na eficiência dos serviços públicos, especialmente aqueles que, para a devida prestação, envolvem a cooperação intergovernamental entre unidades federadas bastante diversificadas.
} 
Ainda sobre a comparação entre ambos os comandos jurídico-constitucionais em questão, há que se consignar, por último, o firme entendimento doutrinário sobre a adequada exegese do parágrafo único do art. 22 da Carta Magna. Em sintonia com o posicionamento de FernANDA Dias MENEZES dE AlmEIDA, é imperioso que se atente para a vedação de, com a delegação eventualmente operada, proporcionar benefícios apenas para uma unidade federada (ou para um agrupamento delas) em detrimento das demais, pois, diante da inexistência de permissão constitucional para tanto, o legislador federal não poderá introduzir os valores imanentes à teoria do federalismo assimétrico nesse campo, mesmo que a intenção mirada seja, reconhecidamente, nobre e pretenda reduzir as disparidades regionais. Ademais, não se pode olvidar que essa prerrogativa colocada à União é incompatível com qualquer tentativa de conferir privilégios ou benefícios injustificados a entes determinados, de forma que qualquer tratamento diferenciador tomado nessa seara violaria o art. 19, inciso III, também da Constiuição da República ${ }^{479}$.

Seja como for, a Federação brasileira, ao eleger a cooperação entre os atores federados como promessa de progresso político e de pacificação das controvérsias regionais, demonstra estar alinhada à tendência, constatada por ALESSANDRA SILVEIRA, materializada na maioria dos sistemas federativos da atualidade em matéria de repartição de competências: trata-se da "progressiva substituição da rigidez da repartição competencial constitucionalmente consagrada pela flexibilidade da cooperação intergovernamental ${ }^{480}$. De acordo com o asseverado, essa inclinação denota a vitória da dimensão procedimental ou preponderantemente política da divisão de encargos e de responsabilidades, que incorpora elementos de interação entre governos na repactuação do exercício competencial, sem que isso resulte em abalo da organização instituída no Estado.

Além disso, esse fato também realça uma perspectiva funcional, ao passo que a cooperação, cada vez mais, revela-se inevitável à subsistência dos Estados compostos, especialmente porque a condução de políticas públicas nem sempre coincidirá com a hermética divisão de competências demarcadas no texto constitucional ${ }^{481}$. A aplicação concreta do princípio da solidariedade visará estabelecer tratamento diferenciado às entidades federativas, na precisa proporção em que elas se distinguem entre si. Diante desse panorama, visualiza-se que somente assim se conseguirá resolver as necessidades apresentadas, pontualmente, pelos variados atores estatais, os quais não podem jamais ter

${ }^{479}$ Cf. Competências na Constituição de 1988, Ob. cit., pp. 93-95. Corrobora essa orientação UADI LammÊGo Bulos, Cf. Curso de Direito Constitucional, Ob. cit., p. 769.

${ }^{480}$ Ob. cit., p. 443.

${ }^{481}$ Cf. Idem, ibidem. 
suas sigularidades esquecidas no equacionamento dos complexos programas de atuação intergovernamental.

A sensibilidade do poder central - encarregado de fixar as diretrizes para a cooperação federativa - deverá, inexoravelmente, levar em conta os aspectos particularizadores de cada uma das unidades autônomas no desenho da rede de relacionamentos federativos. Explica JANICE HELENA FERRERI Morbidelli que o planejamento nacional não poderá negligenciar essa relevante advertência, sob pena de esvaziar a oportunidade de arquitetar um efeciente e racional sistema de colaboração entre instâncias de governo ${ }^{482}$.

Com efeito, enquanto não forem minimamente mapeados os desníveis que prejudicam o desempenho das competências constitucionais comuns, muito provavelmente a obra idealizada pelo constituinte não conseguirá ser construída com integral fidelidade aos valores difundidos no Pacto Fundamental, promulgado em 05 de outubro de 1988. Nessa missão, no que diz respeito aos serviços executados por todos os entes da Federação, coloca-se à União a prerrogativa de, se necessário, empregar assimetrias jurídicas para, a teor do art. 23, parágrafo único, estabelecer um autêntico federalismo participativo, cuja característia notável será a ajustada colaboração entre a União e os entes periféricos. Não há nenhuma incerteza de que, quando se chegar a um quadro de verdadeiro equilíbrio federativo, compensando-se, obviamente, as desigualdades existentes, os benefícios serão vertidos ao conjunto estatal, indistintamente, e, ainda, estar-se-á atendendo parte considerável dos objetivos fundamentais da República.

\section{V.3.2. Regiões Metropolitanas: A Indução da Cooperação Local como Solução aos Problemas Derivados dos Serviços Comuns}

A Região Metropolitana, tal qual assinala AlAÔR CAFFÉ Alves, abrange "um conjunto de relações jurídicas estratificadas em forma de padrões constitucionalmente garantidos" ${ }^{483}$. Sob outro ponto de vista, significa afirmar que, juridicamente, jamais existirão Regiões Metropolitanas se não houver, no mínimo, dois ou mais Municípios que, movidos por questões de índole urbanística, econômica e social, precisarão estabelecer contínuas interações entre seus respectivos governos, com o objetivo precípuo de permitir

\footnotetext{
${ }^{482}$ Cf. Um Novo Pacto Federativo para o Brasil, Ob. cit., p. 236.

483 Planejamento Metropolitano e Autonomia Municipal no Direito Brasileiro, São Paulo, José Bushatsky, 1981, p. 152.
} 
a prestação de serviços públicos às populações envolvidas. Sem relações jurídico-políticas de cooperação, é impossível, portanto, visualizar a formação de Regiões Metropolitanas no âmbito do Estado federal brasileiro ${ }^{484}$.

Atualmente, a criação de Regiões Metropolitanas (assim como de microrregiões e de aglomerados urbanos) constitui prerrogativa do Estado-membro, o qual, nos termos do $\S$ $3^{\text {o }}$ do art. 25 da Constituição Federal ${ }^{485}$, deverá proceder de acordo com sua conveniência e discricionariedade, criando, para tanto, lei complementar específica. Além disso, no que concerne aos motivos que levam ao surgimento de tais regiões, verifica-se que isso tende a acontecer quando, em áreas de conurbação, apenas um Município não consegue resolver, sozinho, determinados problemas que acabam ultrapassando seus limites geográficos, a exemplo dos serviços de abastecimento de água, de tratamento de esgotos, de combate à poluição, de transportes etc ${ }^{486}$. O preceito normativo colocado pelo constituinte permite inferir que o interesse metropolitano, na verdade, reporta a uma função pública de interesse comum, na prática, representada pela promoção e execução de atividades prestacionais que transcendem a concepção de serviço local ${ }^{487}$.

Nesse sentido, as observações de EROS ROBERTO GRAU são interessantes, ao esclarecerem que "as necessidades metropolitanas decorrem do fenômeno da concentração urbana e exigem soluções que só podem ser equacionadas a nível global. Tamanha é a sua maginitude, conexão e interdependência que qualquer problema ou perturbação que alcance apenas uma parte da comunidade metropolitana poderá afetá-la em sua integridade, comprometendo o equilíbrio metropolitano" 488 . E arremata GRAU, registrando que "as soluções a serem conferidas, portanto, não correspondem à simples adição de soluções parciais e isoladas, demandando, para a sua realização, perfeita integração entre todas as unidades de atuação na área metropolitana, públicas e privadas" ${ }^{489}$.

Frente a tais considerações, há que se ter como certo que, embora as Regiões Metropolitanas estejam vinculadas a assuntos frequentemente relevantes para a

\footnotetext{
${ }^{484}$ Cf. AlaÔR CAFFÉ Alves, Ob. cit., p. 152. Esse posicionamento é sufragado por ANDRÉ RAMOS TAVARES, que conceitua as figuras pertinentes ao fenômeno metropolitano como sendo "agrupamentos de Municípios limítrofes, tendo por finalidade básica a resolução de problemas em comum. Seria uma espécie de 'convênio' por agrupamento de Municípios”, Ob. cit., p. 1085.

485 “Art. 25. [...]

$\S 3^{\circ}$ - Os Estados poderão, mediante lei complementar, instituir regiões metropolitanas, aglomerações urbanas e microrregiões, constituídas por agrupamentos de municípios limítrofes, para integrar a organização, o planejamento e a execução de funções públicas de interesse comum".

${ }^{486}$ Cf. Manoel GonÇAlves Ferreira Filho, Curso de Direito Constitucional, Ob. cit., p. 74.

${ }^{487}$ Cf. Edna Cardozo Dias, Regiões Metropolitanas, in Fórum de Direito Urbano e Ambiental (FDUA), ano $7, \mathrm{n}^{\mathbf{o}} 37$, jan./fev. 2008, p. 17.

${ }^{488}$ Regiões Metropolitanas: Regime Jurídico, São Paulo, José Bushatsky, 1974, p. 17

${ }^{489}$ Idem, ibidem.
} 
subsistência do pacto federativo, elas, uma vez constituídas, jamais poderão ser classificadas como entes federados. A natureza jurídica da Região Metropolitana é outra e, sob nenhum prisma, aproxima-se do enquadramento conferido aos atores que integram a Federação. Desprovida de autonomia, a Região Metropolitana não passa de um órgão estadual investido da missão de atuar no planejamento de serviços públicos comuns a Municípios que sofreram processo de conurbação ${ }^{490}$.

A condição atribuída ao órgão metropolitano afasta-lhe a possibilidade de ter personalidade jurídica própria, o que significa ausência de capacidade para o exercício de autogoverno ou de autoadministração ${ }^{491}$. Consoante entende ANTONIO SAMPAIO AMARAL FILHO, a organização metropolitana, "independentemente de sua forma, não poderia ser considerada como um ente político que se situaria entre o Município e o Estado; esta entidade, obrigatoriamente, deveria se ater única e exclusivamente às questões administrativas, sem nenhum tipo de competência normativa, atuando, portanto, somente como correia de transmissão dos Municípios e do Estado-membro, estes sim, plenos em competência, inclusive para legislar atravésde suas Câmaras e Assembléias Legislativas" ${ }^{492}$.

Em complemento, interessa registrar que, "em nosso atual ordenamento, a Região Metropolitana nada mais é do que uma divisão administrativa, podendo se conformar como órgão da administração direta ou entidade da administração indireta, sendo que sua forma será definida e sua administração será realizada como entender melhor o Estado-membro, conforme lei complementar instituídora, nos limites e sob os requisitos da Constituição

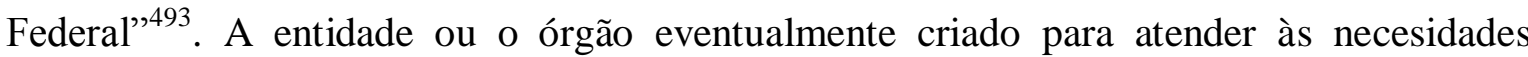
ligadas ao planejamento e à prestação conjunta de serviços em áreas conurbadas terá incumbências limitadas ao âmbito administrativo-financeiro, sendo defesa qualquer espécie de atuação que externe o exercício das prerrogativas inerentes à autonomia

\footnotetext{
490 Nessa altura, vale anotar as diferenças entre os termos "região metropolitana", "microrregião" e "aglomeração urbana". Para tanto, recorre-se a JOSÉ AFONSO DA SILVA, que assim coloca: "Região metropotina constitui-se de um conjunto de Municípios cujas sedes se unem com certa continuidade urbana em torno de um Município-pólo. Microrregiões formam-se de grupos de Municípios limítrofes com certa homogeneidade e problemas administrativos comuns, cujas sedes não sejam unidas por continuidade urbana. Aglomerados urbanos carece de conceituação, mas, de logo, se percebe que se trata de áreas urbanas, sem um pólo de atração urbana, quer tais áreas sejam das cidades sedes dos Municípios, como na baixada santista (em São Paulo), ou não", Curso de Direito Constitucional Positivo, 32ª ed., São Paulo, Malheiros, 2009, p. 665. ${ }^{491}$ Cf. Michel TemER, Elementos de Direito Constitucional, $22^{\mathrm{a}}$ ed., São Paulo, Malheiros, 2008, pp. 114115.

${ }^{492}$ Regiões Metropolitanas, in Revista Trimestral de Direito Público, $\mathrm{n}^{\circ}$ 23, 1998, p. 165.

${ }^{493}$ Pedro Estevam Alves Pinto Serrano, Ob. cit., p. 135.
} 
política, justamente porque à Região Metropolitana inexiste imputação de personalidade política ou caracterização como ente federativo ${ }^{494}$.

Cabe a tais órgãos, pois, estudar os problemas e formular possíveis soluções sobre, de modo que as funções que desempenham ficam adstritas à elaboração e à coordenação de atividades administrativas comuns. Não têm poder político ou administrativo para, por conta própria, prestarem os serviços planejados para a atender as necessidades da área da metrópole, e isso define que sua competência é de mera cooperação com os órgãos de poder político e de capacidade governamental acomodados nos quadros do federalismo ${ }^{495}$. A institucionalização de uma Região Metropolitana não pode jamais desestabilizar a harmonia do pacto federativo, nem tampouco ocasionar a pulverização das competências estabelecidas em prol dos entes federados locais.

Realizados esses apontamentos iniciais, com os quais se procurou situar a Região Metropolitana na sistemática constitucional brasileira, cumpre, agora, proceder à apreciação das prováveis influências que a teoria do fedealismo assimétrico pode trazer a tais órgãos. Nesse compasso, é imprescindível ter em vista que a Região Metropolitana significa "uma modalidade de relacionamento compulsório entre entidades políticoadministrativas" ${ }^{\$ 96}$, o que induz, por óbvio, a atrelá-la ao federalismo cooperativo. Assim sendo, em virtude de a Lei Fundamental de 1988 ser notável promotora da cooperação intergovernamental, não poderá haver lugar, no Estado nacional, para tensão entre a autonomia municipal e o interesse metropolitano, de modo a contrapor os poderes locais e estaduais.

Segundo Pedro Estevam Alves Pinto Serrano, “o intuito primordial da criação do conceito de Região Metropolitana adveio da necessidade de efetivação do preceito constitucional que determina como objetivo destituir a desigualdade econômica e, para tal, o desenvolvimento regional seria claramente um artifício memorável"497. Tomada essa referência, fica claro que a cooperação intergovernamental - principal mecanismo de assimetria jurídica consagrado em nossa ordem constitucional - poderá significar a solução para problemas estrututurais enfrentados nos grandes centros urbanos conurbados, entretanto, é essencial que o Estado-membro estabeça, com êxito, esses centros de gestão administrativa e financeira. Desse modo, observa-se ainda que a cooperação federativa na Região Metropolitana acontecerá em dois níveis: “entre o Estado e os Municípios e entre

\footnotetext{
${ }^{494}$ Cf. Idem, ibidem.

495 Cf. José Alfredo de Oliveira BARACho, Teoria Geral do Federalismo, Ob. cit., p. 143.

496 AlAÔR CAFFÉ AlVES, Ob. cit., p. 163.

${ }^{497}$ Ob. cit., p. 132.
} 
estes, na execução de funções públicas de interesse comum»"498; o que demandará, certamente, bem-elaborados engenhos políticos e jurídicos para garantir o satisfatório funcionamento do órgão em questão.

A propósito, SOL GARSON retrata a amplificada relevância das relações de governo entre os Municípios para o correto funcionamento das aludidas Regiões, admitindo, declaradamente, que "a cooperação entre governos locais pode ser chave para reduzir desigualdades e melhorar a eficiência econômica. [...] Por isso, é importante identificar as condições para promover a cooperação em políticas locais com algum nível de coordenação entre os governos, podendo incluir acordos formais ou informais e fluxos financeiros entre as unidades" ${ }^{499}$. O estudioso atenta ainda para o fato de que, em uma área metropolitana fragmentada, composta por Municípios desiguais quanto às condições socioeconômicas e às capacidades fiscais respectivas, a dificuldade para estabelecer as mencionadas práticas de cooperação será muito maior, devendo os governos estadual e federal também participarem das mencionadas práticas para o emplacamento de um sistema operativo de colaboração intergovernamental ${ }^{500}$.

Mais do que um instrumento de atuação conjugada entre unidades municipais, a Região Metropolitana representa importante peça administrativa para combater os efeitos negativos que assolam alguns Municípios do país, que, por estarem coligados a outros, têm de lidar com uma miríade de mazelas que ultrapassam o interesse puramente local. Como se sabe, não podem os entes municipais envolvidos em uma área conurbada resolver criar, por conta própria, uma Região Metropolitana ${ }^{501}$, entretanto, quando a sensibilidade do legislador estadual for tocada, não há dúvidas de que tais figuras assumem o papel de eficientes mecanismos para lidar com situações e impasses que dificultam o desempenho de serviços públicos imprescindíveis ao bem-estar da população.

Ao Poder Legislativo do Estado-membro compete, portanto, editar, com exclusividade, a lei complementar exigida para o estabelecimento da Região Metropolitana, a qual também disciplinará, de forma integral, os aspectos jurídicos

\footnotetext{
${ }^{498}$ DirCÊO TORRECILlas Ramos, O Federalismo Assimétrico, Ob. cit., p. 200.

499 Regiões Metropolitanas: Por que não Cooperam?, Rio de Janeiro, Letra Capital; e Belo Horizonte, Observatório das Metrópoles, 2009, pp. 74-75.

${ }^{500}$ Cf. Idem, pp. 77-78.

501 A jurisprudência do STF confirma essa orientação, conforme se verifica no voto proferido pelo Ministro CARLOS Velloso, relator da ADI nº 1.841-RJ, julgada pelo Plenário do STF em 01/08/2002, ocasião em que se decidiu pela inconstitucionalidade material do art. 357, parágrafo único, da Constituição do Estado do Rio de Janeiro, porque o ato normativo estadual sujeitava a criação de Região Metropolitana à prévia aprovação por parte das respectivas Câmaras Municipais de cada um dos entes federados envolvidos; texto extraído de documento digital disponível no sítio eletrônico: www.stf.jus.br, acesso em 30/12/2009.
} 
relativos à configuração institucional e ao funcionamento da entidade que vier a ser instituída. Nesse particular, o Estado-membro, obrigatoriamente, terá de levar em conta os valores que permeiam a Federação nacional para idealizar o substrato normativo que concede vida à Região Metropolitana, sob pena de incorrer em contrariedade ao espírito de eficiência sacramentado na Lei Maior. Propagando a necessidade de tais órgãos estaduais estarem em sintonia com o espírito de cooperação e de solidariedade federativas, DIRCÊO TORRECILLAS RAMOS sintetiza que "a busca da cooperação, da diminuição das desigualdades da assimetria, num federalismo novo, de equilíbrio" ${ }^{, 502}$, devem ser a razão de existir de qualquer Região Metropolitana.

O maior desafio colocado à fórmula política responsável pela ordenação da Região Metropolitana é, sem dúvida, o de traçar um sistema no qual, em matéria de domínio administrativo e decisório, haja igualdade material entre o Estado e os Municípios, uma vez que ambos os níveis governamentais deverão participar ativamente das ações praticadas na área conurbada ${ }^{503}$. Aqui, as ferramentas de compatibilização das disparidades federativas caracterizadoras da teoria do federalismo assimétrico devem ser evocadas com o fito de permitir que cada Município integrante da Região Metropolina, não obstante as diferenças que lhes caracterizarem, possam ter idêntica influência no planejamento e na execução dos serviços a serem prestados. Essa advertência não pode ser esquecida porque a figura governamental comentada, longe de negar a importância dos Municípios deve reafirmar o valor e a relevância desses entes no quadro geral das instituições fundamentais que caracterizam nossa vida político-organizacional ${ }^{504}$.

Averbe-se que o constituinte bandeirante parece ter seguido essa recomendação ao abrigar, no art. 154 da Constituição do Estado de São Paulo ${ }^{505}$, mandamento que externa o compromisso de, no tocante ao poder decisório, resguardar a igualdade entre os Municípios e o ente estadual. Em que pese a importância do preceito destacado, é lamentável constatar que o legislador estadual manteve-se inerte e não elaborou a lei complementar demandada para regulamentar a participação paritária do conjunto de Municípios face ao Estado nas atividades incumbidas à Região Metropolitana. Isso sugere, dentre outras coisas, que ainda não foram percebidos, ao menos no plano do constitucionalismo paulista, os inúmeros

\footnotetext{
502 O Federalismo Assimétrico, Ob. cit., p. 200.

${ }^{503}$ Cf. Pedro Estevam Alves Pinto Serrano, Ob. cit., p. 125.

${ }^{504}$ Cf. AlaÔr CAFFÉ Alves, Ob. cit., p. 157.

505 “Art. 154. Visando a promover o planejamento regional, a organização e execução das funções públicas de interesse comum, o Estado criará, mediante lei complementar, para cada unidade regional, um conselho de caráter normativo e deliberativo, bem como disporá sobre a organização, a articulação, a coordenação e, conforme o caso, a fusão de entidades ou órgãos públicos atuantes na região, assegurada, nestes e naquele, a participação paritária do conjunto dos Municípios, com relação ao Estado”.
} 
benefícios que podem ser alcançados com a correta utilização desse instituto de cooperação intergovernamental, consubstanciado na Região Metropolitana.

Ao se admitir a relevância de tais organismos para o fortalecimento do pacto federativo no país, arrisca-se emitir o palpite de que, quando as Regiões Metropolitanas estiverem devidamente afinadas com as proposições encontradas no âmago da teoria que diciplina a aplicação das assimetrias na Federação, ter-se-á caminhado bastante para a obtenção do necessário equilíbrio entre os níveis governamentais, aos menos nos grandes centros urbanos conurbados. Para que isso aconteça, é inarredável que, consoante prega MARCElo Rocha SABOIA, cada Região Metropolitana receba tratamento compatível com suas peculiaridades, pois o elemento político materializado com o seu surgimento nunca poderá negar a realidade social, política e econômica que a antecede ${ }^{506}$.

Assim, a conclusão que se deve tirar é a de que caberão às ideias veiculadas pelo federalismo assimétrico permitir que o mesmo instituto jurídico atenda as necessidades de um conglomerado de 39 Municípios, como é o caso da Região Metropolitana de São Paulo, ou de uma área que interligue apenas 5 Municípios, a exemplo do que ocorre com a Região Metropolitana de Recife. Esses números são apenas exemplos das muitas disparidades escondidas na conformação de nosso pacto federativo, o que evidencia a imprescindibilidade de se abandonar a noção, há muito estabelecida, de que os entes da Federação devem ser tratados como se fossem realidades formalmente igualadas. A insistência em manter esse paradigma servirá, por certo, para fazer com que as desigualdades fáticas continuem a se multiplicar, e a ineficiência administrativa, potencializada pela ausência de coesão e solidariedade nas relações entre governos, permaneça atravancando o desenvolvimento do país como um todo.

\section{V.3.3. As Regiões Administrativas: A Integração de Unidades Geográficas em Desenvolvimento}

Com base nos aspectos já explicitados, a comprovação de que a atual Constituição Federal objetivou criar novos parâmetros para a institucionalização das relações intergovernamentais torna-se inafastável. Buscou-se ainda, na medida do possível, corrigir as disfunções existentes no regime de cooperação, as quais foram sendo formadas desde a primeira metade do século XX, quando a Federação nacional começou a ser transformada

${ }^{506}$ Cf. Notas Sobre as Regiões Metropolitanas, in Revista de Informação Legislativa, ano 35, $\mathrm{n}^{\circ} 138$, abr./jun. 1998, p. 236. 
em um palco de atos e de práticas colaborativas entre os entes autônomos ${ }^{507}$. Nesse contexto, o papel de predominância da União na resolução dos problemas nacionais não é nenhuma novidade, entretanto, pretendeu a Constituinte convocada em 1987 fazer com que as tendências centralizadoras do governo federal fossem neutralizadas pelo princípio da solidariedade, conforme se verifica no caso de exercício de competências comuns (art. 23, parágrafo único, da $\mathrm{CF}$ ) e, na hipótese de integração administrativa de regiões geoeconômicas e soiciais a fim de diminuir as desiguladades regionais, em observância ao regramento estabelecido pelo art. 43 do texto constitucional vigente ${ }^{508}$.

Explica ALEXANDRE DE MORAES que o presente preceito "caracteriza-se por ser norma instrumental para efetividade de dois dos objetivos fundamentais da República, previstos nos incisos II ('garantir o desenvolvimento nacional') e III ('erradicar a pobreza e a marginalização e reduzir as desiguldades sociais e regionais') do art. $3^{\circ}$, tendo como finalidade permitir o auxílio da União ao desenvolvimento de regiões menos favorecidas" ${ }^{\prime 509}$. Prossegue o autor, advertindo que, na verdade, o governo federal não tem a mera faculdade de implementar esse instituto; está, em verdade, obrigado a fazê-lo, "sob pena de ferimento a uma das vedações previstas no inciso III do art. 19 ('É vedado à União, aos Estados, ao Distrito Federal e aos Municípios: III - criar distinções entre

\footnotetext{
${ }^{507} \mathrm{Na}$ órbita do Estado federal no país, a afirmação histórica da política de desenvolvimento regional é elucidada por GiLBERTo BERCOVICI, nos seguintes termos: "A Constituição de 1946 consolidou a estrutura cooperativa no federalismo brasileiro, prevista já em 1934, com grande ênfase na redução dos desequilíbrios regionais, favorecendo, apesar do reforço do poder federal, a cooperação e a integração nacional. Foi sob a vigência desta Constituição, na década de 1950, que a Questão Regional ganhou importância no debate político nacional, com a concepção de que a atuação estatal e o planejamento eram elementos essenciais para o desenvolvimento, de acordo com as diretrizes elaboradas pela recém-criada CEPAL. Desde então, todas as constituições brasileiras têm a preocupação de tentar consagrar instrumentos para a superação das desigualdades regionais", Formação e Evolução do Federalismo no Brasil, in Lições de Direito Constitucional em Homenagem ao Jurista Celso Bastos, André Ramos Tavares, Gilmar Ferreira Mendes e Ives Gandra da Silva Martins (coord.), Ob. cit., p. 724.

508 “Art. 43. Para efeitos administrativos, a União poderá articular sua ação em um mesmo complexo geoeconômico e social, visando a seu desenvolvimento e à redução das desigualdades regionais.

$\S 1^{\circ}$ - Lei complementar disporá sobre:

I - as condições para integração de regiões em desenvolvimento;

II - a composição dos organismos regionais que executarão, na forma da lei, os planos regionais, integrantes dos planos nacionais de desenvolvimento econômico e social, aprovados juntamente com estes.

$\S 2^{\circ}$ - Os incentivos regionais compreenderão, além de outros, na forma da lei:

I - igualdade de tarifas, fretes, seguros e outros itens de custos e preços de responsabilidade do Poder Público; II - juros favorecidos para financiamento de atividades prioritárias;

III - isenções, reduções ou diferimento temporário de tributos federais devidos por pessoas físicas ou jurídicas;

IV - prioridade para o aproveitamento econômico e social dos rios e das massas de água represadas ou represáveis nas regiões de baixa renda, sujeitas a secas periódicas.

$\S 3^{\circ}$ - Nas áreas a que se refere o $\S 2^{\circ}$, IV, a União incentivará a recuperação de terras áridas e cooperará com os pequenos e médios proprietários rurais para o estabelecimento, em suas glebas, de fontes de água e de pequena irrigação".

${ }_{509}$ Constituição do Brasil Interpretada e Legislação Constitucional, $6^{\text {a }}$ ed., São Paulo, Atlas, 2007, p. 1021.
} 
brasileiros ou preferências entre si'). Portanto, o Congresso Nacional deverá pautar-se, para a composição dos organismos regionais, no interesse geral de desenvolvimento homogêneo das diversas regiões da Federação" ${ }^{\text {,510. }}$.

Conforme o esquadrinhado, fica evidenciada a competência da União na institucionalização, por meio de lei complementar, das "regiões de desenvolvimento (art. 43), que apresentam as seguintes características: efeitos administrativos; articulação de uma ação social e econômica conjunta para o desenvolvimento da região, como concessão de incentivos, juros favorecidos etc" $" 511$. Interessa anotar também que a natureza jurídica dessas figuras é bastante singular, haja vista que, "na verdade, não são entes federativos autônomos como os Estados, o Distrito Federal e os Municípios, nem descentralizações administrativas, como os Territórios. Ao contrário, abrangem áreas que constituem complexos geoeconômicos e sociais, politicamente pertencentes, eventualmente, à esfera

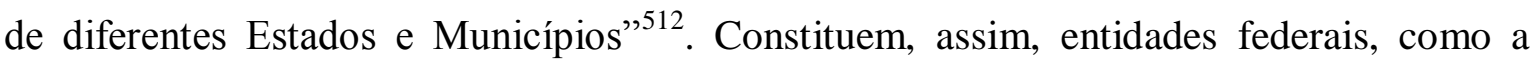
SUDAM (Superintendência do Desenvolvimento da Amazônia) e a SUDENE (Superintendência do Desenvolvimento do Nordeste) ${ }^{513}$.

Embora a Carta Republicana de 1946 já trouxesse previsões capazes de contribuir para o fortalecimento dos organismos analisados, observa-se que foi a atual Constituição que, pela primeira vez, elevou-os ao nível constitucional positivo ${ }^{514}$. Esse aspecto histórico, ao ser contextualizado no campo da evolução do Estado brasileiro, conduz à conclusão de que o constituinte de 1987-1988 quis, deliberadamente, aumentar a importância desses engenhos, num visível esforço para melhorar o quadro fático das parcelas territoriais menos desenvolvidas do país. Isso, em nenhum momento, denota que,

\footnotetext{
${ }^{510}$ Idem, pp. 1021-1022.

511 ANDRÉ RAMOS TAVARES, Ob. cit., p. 1066.

${ }^{512}$ Manoel GonÇalves Ferreira Filho, Curso de Direito Constitucional, Ob. cit., p. 74.

513 A propósito, cabe registrar que GILBERTO BERCOVICI coloca a principal distinção entre regiões administrativas, previstas no âmbito do constitucionalismo brasileiro, e as regiões que integram o Estado italiano e espanhol. Em síntese, considera que "a Região da Itália e a Comunidade Autônoma da Espanha são entidades territoriais de personalidade jurídica de direito público própria e que são dotadas de capacidade de autogoverno e autonomia legislativa. Já a Região da Constituição de 1988 é fruto de mera descentralização administrativa, não política, isto é, não passa de uma autarquia”, Desigualdades Regionais, Estado $e$ Constituição, Ob. cit., p. 234.

514 Segundo elucida RAUL MACHADO HORTA, coube à previsão encartada "no Ato das Disposições Constitucionais Transitórias da Constituição Federal de 1946, que impunha ao Governo Federal a obrigação de traçar e executar um plano de aproveitamento total das possibilidades econômicas do Rio São Francisco e seus afluentes, aplicando-se nesse plano, anualmente, quantia não inferior a um por cento das rendas tributárias da União (art. 29)", trazer o preceito jurídico-constitucioal que inaugurava, ainda que tangencialmente, o relevo dos órgãos federais de desenvolvimento regional, Tendências Atuais da Federação Brasileira, Ob. cit., pp. 10-11.
} 
como propaga PAUlo BONAVIDES, o Estado nacional estende às regiões administrativas "chave institucional da reorganização federativa",515.

As regiões administrativas, analisadas em sua essência, correspondem ao reconhecimento, por parte da ordem constitucional, de que o Brasil apresenta realidades socioeconômicas que nem sempre coincidem com algumas porções específicas do território nacional abarcadas pelo aparato técnico-burocrático de um Estado ou um Município, em específico ${ }^{516}$. Essa lógica das regiões entusiasmava CELSO BASTOS, que, em 1985, recomendou à futura Assembleia Nacional Constituinte dispender muita atenção às questões que circundavam a operacionalização das transferências de rendas das regiões que mostrassem condições de propiciá-las para aquelas mais carentes ${ }^{517}$. Entendia ainda que o remanejamento de receitas não poderia implicar, em nenhum momento, responsabilização da União pela execução dos serviços voltados a fomentar o desenvolvimento regional $^{518}$.

A justificativa para o surgimento de tais regiões de desenvolvimento, vista sob outro ângulo, encontra fundamento, em certa medida, no caráter dinâmico que acompanha o conceito de federalismo, pois as estruturas de descentralização política estão, incessantemente, sujeitas às oscilações ocorridas na tessitura social e, nem sempre, a adaptação do regime dependerá de mudanças de ordem política. As fortes adversidades territoriais congregadas no interior do Estado brasileiro, aliadas às constantes alterações da base fática em que o regime federativo é executado, exigiram novas posturas e diretrizes para equacionar a questão das disparidades regionais ${ }^{519}$. Nessa direção, enfatiza MANOEL GONÇALVES FERREIRA FILHO que as aludidas peças da organização estatal apontam para "uma dissimetria de tratamento entre os Estados quanto à atuação administrativa e a estimulação do desenvolvimento" ${ }^{, 520}$, objetivando, em tese, atenuar as problemáticas consequências da desigualdade.

\footnotetext{
${ }^{515}$ A Constituição Aberta: Temas Políticos e Constitucionais da Atualidade, com ênfase no Federalismo das Regiões, Ob. cit., p. 344.

516 Cf. Maria Garcia, O Modelo Político Brasileiro: Pacto Federativo ou Estado Unitário, in Lições de Direito Constitucional em Homenagem ao Jurista Celso Bastos, André Ramos Tavares, Gilmar Ferreira Mendes e Ives Gandra da Silva Martins (coord.), Ob. cit., p. 806. Em complemento, JosÉ CRETELLA JúnIOR consigna que a "região administrativa é uma coletividade pública, com desigualdades regionais e com pequeno desenvolvimento. Técnicos da União, depois de estudos e pesquisas, descobrem a potencialidade da região. Ora, a finalidade da incidência da articulação da ação da União é o melhor aproveitamento possível da área, observando-se, pelo contexto constitucional, que se trata, regra geral, de terras áridas que necessitam de irrigação, como as do Nordeste, sujeitas a secas periódicas, mas prolongadas", Comentários à Constituição Brasileira de 1988, vol. 5, Rio de Janeiro, Forense Universitária, 1991, p. 2468.

${ }^{517}$ Cf. A Federação no Brasil, Ob. cit., p. 60.

${ }^{518} \mathrm{Cf}$. Idem, ibidem.

${ }^{519}$ Cf. Luis Roberto Barroso, Ob. cit., p. 3.

${ }^{520}$ Aspectos do Direito Constitucional Contemporâneo, Ob. cit., p. 181.
} 
Em abono, JANiCe Helena FerReri Morbidelli registra que "a inserção do dispositivo estabelecendo a criação de regiões administrativas merece destaque, pois introduziu elementos de tratamento diverso entre os Estados, que corresponde à necessidade de reequilíbrio entre regiões de grande desenvolvimento. Esse componente na Constituição denota a institucionalização de um federalismo assimétrico, de atendimento constitucional a desigualdades incompatíveis com a simetria do federalismo tradicional” ${ }^{, 521}$. Mais uma vez, a redução das disparidades regionais não pode abrir mão das interações entre os governos da Federação, mesmo quando é da União a competência para instituir a entidade voltada a viabilizar o desenvolvimento de regiões determinadas do país.

O que se pretende, aqui, é, em suma, consignar a importância do emprego, no momento de elaboração da lei complementar federal criadora da sobredita figura regional, da técnica da diferenciação de encargos e de competências entre as unidades políticas. Não se apresenta interessante que o governo federal alije os demais entes da execução dos serviços prestados pela entidade em questão, porque é certo que a soma de esforços da União, dos Estados e dos Municípios, de modo que todos possam colaborar com a política de desenvolvimento traçada para o complexo geoeconômico e social, apresenta-se como a fórmula mais indicada para a superação das dramáticas heterogeneidades regionais. Para a consecução desse elevado propósito, DIRCÊO TORRECILLAS RAMOS sugere que as regiões de desenvolvimento submetam-se a um sistema de nomeação, fiscalização e controle, por órgãos interestaduais e por órgãos de articulação nessas relações, inclusive com a participação dos demais Estados de outras regiões do país ${ }^{522}$.

Reforça o entendimento de TORRECILLAS RAMOS, acerca da importância de representantes das unidades federadas não situadas no raio de atuação da região administrativa também participarem de sua gestão, o fato de que as receitas federais direcionadas às localidades eventualmente atendidas são auferidas em todo o território nacional. Por tal razão, mostra-se desrazoável afastar esses instrumentos de proteção dos

\footnotetext{
${ }^{521}$ Um Novo Pacto Federativo para o Brasil, Ob. cit., p. 239. .Comungando do mesmo entendimento, Celso Ribeiro Bastos e Ives GandRa Martins enunciam que "as regiões, tais como esculpidas no Texto Constitucional, constituem um instrumento destinado a levar a cabo uma política de favorecimento às áreas menos desenvolvidas do País. De fato, o princípio federativo, inicialmente, repeliria esse tratamento desuniforme do qual certos Estados acabarão por se beneficiar. O princípio do tratamento isonômico aos Estados-membros é basilar na estrutura do Estado federal. O certo é que desde longa data as diferenças regionais têm servido de base legitimadora para a outorga de um tratamento mais benéfico às de menor desenvolvimento socioeconômico. É uma medida que mais se coadunaria com o Estado unitário. Sabemos das deficiências do nosso pacto federativo, a unir entidades do território, população e desenvolvimento muito diferençados, fenômeno ao qual a União não pode permanecer indiferente", Comentários à Constituição do Brasil: Promulgada em 5 de outubro de 1988, vol. 3, tomo III (Arts. 37 a 43), São Paulo, Saraiva, 1992, p. 284.

${ }^{522}$ Cf. O Federalismo Assimétrico, Ob. cit., p. 199.
} 
interesses daqueles que contribuirão para promover o desenvolvimento dessas parcelas do país, mormente porque acreditam que os incentivos podem conduzir a níveis satisfatórios de equilíbrio econômico, social e político entre os atores políticos da Federação ${ }^{523}$. Além disso, o autor preconiza que a lei complementar federal que criar as regiões de desenvolvimento terá de, imprescindivelmente, trazer detalhados os planos e os prazos relativos aos programas a serem implementados, bem como referências temporais inconfundíveis para o início e o fim das atividades desempenhadas pela própria entidade regional, objetivando-se, de tal sorte, evitar o desvirtuamento dos propósitos que serviram de motivo para sua criação ${ }^{524}$.

Desse modo, no que respeita às regiões de desenvolvimento, cabe à União assumir o papel crucial de idealizar estruturas administrativas que permitam a coordenação e a articulação de todas as esferas governamentais na elaboração e na execução do planejamento nacional. $\mathrm{O}$ federalismo cooperativo, de sua parte, abre caminho para que a negociação política entre o poder central e os demais entes federados seja a técnica de maior importância na engenharia dos instrumentos desenvolvimentistas aplicáveis às regiões do país, o que, por conseguinte, certifica de que o sucesso para a atuação das regiões administrativas passa antes por um acertado ajuste político entre as unidades autônomas do Estado federal ${ }^{525}$.

Os planos de desenvolvimento a serem executados pelas referidas regiões administrativas não poderão abrir mão da participação efetiva de todas as instâncias governamentais, o que, sem dúvida, exigirá apurada sensatez do legislador federal na delimitação do enquadramento de cada ente federado ligado ao complexo geoeconômico. Aguarda-se, portanto, que a lei complementar instituídora da região aporte um sistema fundado no devido ajustamento dos encargos e atribuições entre os governos, como recurso de superação dos impasses econômicos e sociais identificados nos quadros regionais do país. Em termos diversos, significa afirmar que as ações de planejamento regional deverão estar atentas às assimetrias de fato para que se compatibilizem as diferenças entre os entes e, dessa maneira, cada qual possa receber tratamento condizente com suas respectivas condições, seja em relação às tarefas e serviços a serem prestados no âmbito do organismo regional, seja ainda no tocante aos incentivos e demais instrumentos de indução do crescimento econômico e social que vierem a ser aplicados.

\footnotetext{
${ }^{523}$ Cf. Idem, ibidem.

${ }^{524} \mathrm{Cf}$. Idem, ibidem.

${ }^{525}$ Cf. Gilberto Bercovici, Desigualdades Regionais, Estado e Constituição, Ob. cit., p. 215.
} 
Além disso, o $\S 2^{\circ}$ do art. 43 da Lei Maior enuncia, em um rol enumerativo, quais as medidas que poderão traduzir-se em incentivos regionais. A interpretação tirada de tal comando certifica que o federalismo brasileiro não é avesso ao tratamento diferenciado de determinadas unidades político-administrativas, o que reflete, consequentemente, sua visível feição assimétrica. Seja mediante uniformização de preços dos serviços públicos prestados pela União; seja por meio da fixação de juros favorecidos para o financiamento das atividades prioritárias; ou ainda em decorrência de regras tributárias mais benéficas (isenção, redução ou diferimento) de tributos federais, o poder central poderá incentivar o crescimento de regiões em desenvolvimento discriminando-as positivamente como forma de compensar o grau de retardamento que as aflige ${ }^{526}$.

Considerando-se, por fim, o arcabouço jurídico-institucional desenhado pelo constituinte, parece ser impossível refutar a conclusão de TORQUATO JARDIM de que, no que respeita ao federalismo brasileiro, a construção do equilíbrio passa pela aceitação da premissa de que existem desigualdades entre as partes federadas, formalmente admitidas como iguais pelo texto constitucional ${ }^{527}$. Os entes autônomos subnacionais precisam reconhecer a União como responsável pela coordenação e planejamento das ações do conjunto, a teor da norma constitucional consignada no parágrafo único do art. 23 e nas disposições atinentes à ordenação das regiões de desenvolvimento (art. 43 e parágrafos). O governo federal, por sua vez, está proibido de sobrepor sua vontade aos elevados interesses de unidade e de harmonia que regem a Federação, já que sua atuação, mesmo no que respeita à implementação de medidas de acomodação das disparidades, deve sempre estar em consonância com os quadrantes indicativos de coesão do sistema, o que significa que a autonomia franqueada aos demais atores federativos nunca poderá ser desconsiderada.

${ }^{526}$ Celso Ribeiro Bastos e IVEs Gandra Martins, Ob. cit., pp. 287-289.

${ }^{527}$ Cf. Ob. cit., p. 217. 


\section{CONCLUSÃO}

A existência de desníveis entre os vários atores que integram o concerto federativo importa em pressuposto natural para a institucionalização de qualquer Estado federal, uma vez que a essência dessa forma estatal está justamente na intenção de unir partes que, em razão de múltiplas características, acabam sendo diferentes. Por óbvio, a decisão de construir uma Federação deve, obrigatoriamente, considerar o quanto essa diversidade pode ser um complicador para o bom funcionamento dos laços associativos e das instituições a serem idealizadas. Assim, se o juízo realizado atestar que as diferenças são de acentuada severidade a ponto de isso as tornarem impossíveis de compatibilização, é certo que o ímpeto federalista deverá ser abandonado, uma vez que nenhum recurso jurídico e político disponível conseguirá evitar o fracasso do Estado federal que nestes moldes vier a ser criado.

Ocorre, entretanto, que nem sempre é possível precisar, de modo apriorístico, todos os reflexos das heterogeneidades regionais nas instituições idealizadas para servirem de suporte no processo de descentralização político-territorial do poder. Além disso, é comum que o dinamismo das relações intergovernamentais, bem como a inconstância dos demais elementos que interferem no sucesso do pacto federativo, tragam a necessidade de acomodar os desníveis que, porventura, tenham surgido após estabelecidos os mecanismos responsáveis pela subsistência da Federação. O mesmo raciocínio há de ser empregado no tocante aos quadros fáticos em que o federalismo se apresenta como opção viável, mas a antevisão de prováveis problemas estruturais indica quais ferramentas de correção devem ser utilizadas, a fim de precaver qualquer espécie de prejuízo ao sistema instituído.

A acomodação das diferenças regionais, por sua vez, representa um ponto sempre delicado na tarefa de construir Estados federais onde as disparidades, embora identificadas em patamares preocupantes, não chegam a constituir um impedimento intransponível para a adoção do regime federativo. Para atender a tal propósito, novos conceitos tiveram de ser introduzidos no campo da descentralização política, e esse fato significou, por conseguinte, a quebra de algumas ideias tradicionalmente ligadas à teoria geral do federalismo. Com a reformulação dos paradigmas responsáveis por definir o planejamento constitucional e as relações intergovernamentais praticadas entre os entes autônomos, percebeu-se que determinados mecanismos jurídicos poderiam ser estabelecidos como uma eficiente 
maneira de combater os efeitos negativos aportados pela falta de uniformidade das peças dos integrantes da Federação. Surgiu, assim, o federalismo assimétrico.

Os avanços proporcionados pela incorporação de assimetrias jurídicas no âmbito das Constituições de alguns Estados compostos retratam que as forças desagregadoras da unidade estatal podem ser racionalmente neutralizadas por meio de instrumentos conformadores da diversidade das partes. Em outras palavras, ficaram comprovados os surpreendentes benefícios que a diferenciação dos entes federados, com vistas a colocá-los em situação de equivalência para o exercício das competências que lhes são atribuídas, traz aos contextos em que a gravidade das variações regionais reclama o emprego dessa técnica. As salutares mudanças sentidas em decorrência do emprego concreto da tese do federalismo assimétrico, de fato, importam em vigoroso indicativo da permanência desse modelo organizacional no constitucionalismo do porvir.

Como assegurar a unidade de Estados onde a diversidade não representa apenas uma característica esperada mas, antes, é um problema para a coesão do pacto federativo e para a interação dos sujeitos governamentais? Possibilitar que as respostas para essa difícil pergunta sejam encontradas é a destacada missão colocada ao federalismo assimétrico, o que, como se infere, acabará conduzindo a um sem-número de soluções viáveis, pois cada Federação precisa encontrar uma fórmula adequada para contornar os seus pontos de tensões. Nessa direção, guardados os valores gerais que informam a teoria das assimetrias, os Estados federais terão de ser tomados em específico, uma vez que cada um deles possui características próprias, as quais terão de ser computadas para a obtenção dos acertados instrumentos de acomodação das diferenças.

Consignados os apontamentos gerais sobre a problemática que ocupa os estudiosos do federalismo assimétrico e admitindo-se principalmente as considerações explanadas nos capítulos precedentes, delimita-se, aqui, no final deste trabalho, duas conclusões principais acerca da vertente assimétrica do Estado federal. Anote-se que essas verificações correspondem a ideias retoras do emprego das dissimetrias pelos Estados que já incluiram essa técnica em seus respectivos pactos políticos e, em última análise, acabam sendo a fonte irradiadora das demais constatações apuradas na análise realizada. Adverte-se então que a diferenciação federativa tem implicações outras que ultrapassam esses dois aspectos referidos e, somente após conhecidas as mais proeminentes questões que circundam o federalismo assimétrico, é que as demais verificações serão apreciadas.

A primeira conclusão geral a que se chega é a de que o federalismo - conforme entendimento que vem sendo construído desde o século XVIII - constitui, de fato, a forma 
de Estado mais indicada para a organização política de países que pretendam construir um regime democrático. Visualiza-se, portanto, que essa indissociável ligação entre Federação e democracia foi decisiva para possibilitar o aperfeiçoamento dos laços associativos celebrados entre os entes federados por meio dos paradigmas e das ideias difundidos pela assimetria. Dessa forma, a afirmação de que inexistirá federalismo assimétrico em países que não apresentem grande apreço ao regime democrático, firma-se como inevitável.

Na sequência, a segunda ilação mencionada reporta à reconhecida flexibilidade das estruturas que acompanham o Estado federal. Mais precisamente, diz respeito aos reflexos advindos da adoção, após o término da Segunda Guerra Mundial, do Estado social como modelo de ordenação dos órgãos de poder e das funções conferidas ao Estado em vários países. A maleabilidade ínsita ao pacto federativo foi crucial para que as bases de sustentação de algumas Federações fossem redefinidas com o objetivo de adaptá-las às orientações preconizadas pela democracia social, a exemplo das aspirações de promover o respeito aos direitos das minorias; manter unidas regiões com história e tradições, às vezes, conflitantes e, ainda, estabelecer novos padrões na prestação de serviços públicos, buscando assegurar níveis ótimos de eficiência administrativa, mesmo em Estados que apresentam graves disparidades internas.

Diante de tais certificações, é impossível afastar da órbita do federalismo as assimetrias que, hoje, são uma realidade e, inquestionavelmente, significam importantes ferramentas disponibilizadas à engenharia constitucional para o ajustamento das disparidades fáticas que se apresentam nos Estados compostos. A diferenciação jurídica das partes federadas não requer apenas a previsão de competências constitucionais distintas aos entes situados no mesmo plano governamental, pode ainda abarcar a disciplina das relações entre governos, com o intuito de evitar prováveis prejuízos que seriam sentidos, caso a cooperação ficasse confinada ao campo exclusivo da política. Ademais, percebe-se que as necessidades colocadas pela democracia social, em especial no tocante à implementação de programas estatais voltados à prestação de serviços públicos, foram determinantes para que o Estado federal buscasse meios de reduzir as implacáveis consequências criadas pela heterogeneidade regional, e isso, pelo que se pode inferir, redundou no aparecimento de Federações assimetricamente estruturadas.

Baseado na premissa de que as normas jurídicas devem promover o equilíbrio dos entes autônomos - todos eles desiguais entre si, por força de motivos variados -, o federalismo assimétrico visa fazer com que o Direito Constitucional seja exitoso no balanceamento das diversidades territoriais. O escopo primeiro perseguido com a 
implantação de ferramentas compensatórias das diferenças é o de homogeneizar os aludidos atores políticos, evitando-se, de tal sorte, que o regime federativo venha a se configurar num palco de animosidades e conflitos inter-regionais. Em verdade, as assimetrias tão-somente fazem o que, naturalmente, se espera que aconteça com o federalismo: viabilizar a concretização do conhecido adágio que traduz o núcleo irredutível do Estado federal, qual seja, permitir que se tenha unidade da organização estatal sem, no entanto, exterminar as diversidades de suas partes.

Para que haja compreensão plena dos instrumentos afeitos ao Estado federal assimétrico é recomendável empreender análise de experiências estrangeiras já consolidadas nesse sentido. Ainda que os desafios enfrentados por outras organizações estatais muito provavelmente não sejam os mesmos que atrapalham o funcionamento da Federação brasileira, as anotações comparatísticas em Direito não deixam de ser valiosos recursos para direcionar a elaboração de institutos constitucionalmente adequados à realidade nacional. Confirma a importância dessa técnica a certeza de que as normas jurídicas são, além de mecanismos de estabilização social, formas viáveis de reenquadrar os ambientes onde são inseridas, e isso sugestiona que, do mesmo modo que alguns países lograram sucesso em contornar os embaraços decorrentes da heterogeneidade de suas regiões, o Brasil também pode fazê-lo.

Numa perspectiva jurídica, enxerga-se que a noção de igualdade formal aplicada às unidades federadas é insuficiente para fazer com que se alcance o equilíbrio entre elas, principalmente se o cenário no qual o Estado federal fincar suas bases estiver marcado por profundas adversidades. Ter as unidades periféricas como se fossem absolutamente idênticas, por certo, potencializa o aparecimento de dissimetrias de fato, já que é ilógico atribuir iguais competências e encargos aos entes, deixando de lado a preocupação de saber se eles conseguirão ou não cumpri-los. Além disso, as diferenciações realizadas no âmbito do concerto federativo devem visar, ainda, que os governos subnacionais sejam postos na mesma posição no que respeita ao poder de negociação com a União e com os demais entes, coibindo-se, assim, a corrosão do pacto político pela atuação hierarquizada de determinados entes.

Em que pesem os anunciados benefícios que poderão derivar das assimetrias de direito, alguns limites terão de ser rigorosamente observados para não transformar a solução aventada num problema ainda maior do que aquele que se teria com os desníveis regionais. O postulado da igualdade entre os entes - que, por sua vez, desdobra-se na proibição de discriminação federativa - é crucial nesse ponto, porque a proposta de 
implantar uma Federação não-simétrica deve, fundamentalmente, estar lastreada no compromisso de assegurar, numa mesma intensidade, direitos a todos os indivíduos e agrupamentos sociais. O outro aspecto que não poderá ser esquecido é a manutenção da unidade estatal que, em termos práticos, converte-se em cuidados para que as diferenciações jurídicas adotadas não se reflitam em abalos à coesão do conjunto amarrado pelos laços políticos caracterizadores do Estado federal. Por último, a principiologia subjacente à ideia de solidariedade precisará fazer-se presente na elaboração dos mecanismos assimétricos, na medida em que os cuidados em relação à cooperação intergovernamental são indispensáveis para integrar todas as unidades políticas num único projeto político de Federação.

Depois de assinalados os pontos de maior envergadura para a formação de regimes assimétricos de descentralização do poder político, cumpre iniciar a análise dos fatores que se referem especificamente ao federalismo brasileiro. Entre nós, cumpre atestar, de plano, a imprescindibilidade de utilizar-se os aparatos jurídicos tendentes a amenizar as diferenças regionais, pois a obtenção de níveis apropriados de equilíbrio representa um desafio, até o momento, ainda pendente de alcance. Ademais, não é de hoje que os mecanismos tradicionais meios de descentralização do poder político encontram-se desgastados não pelas fortes heterogeneidades naturais, que são marcas indisfarçáveis de nosso território, mas, principalmente, em virtude de abruptos desníveis socioeconômicos, formados desde a gênese do Estado federal no país, e que acabaram sendo alimentados de modo contínuo durante das sucessivas Constituições aqui experimentadas.

Com efeito, o processo de afirmação histórica do Estado federal brasileiro apresenta várias etapas. Entretanto, nenhuma delas conseguiu superar os complicados obstáculos governamentais oriundos dessa diversidade. No percurso que se instaura com o federalismo vivenciado na República Velha e que segue até a Federação arquitetada pelo Pacto Fundametal de 1988, com vistas a promover a solidariedade federativa, identificamse sérios problemas que repousam exatamente nos contrastes aferidos entre as unidades autônomas. O desinteresse político e as resistências encontradas para corrigir esse manifesto impasse do federalismo nacional, além de ser, na prática, causa impeditiva do desenvolvimento integrado do país, transmuta-se em sistemática violação da vontade externada pelo texto constitucional em vigor.

$\mathrm{Na}$ verdade, um estudo detido da atual Constituição Federal revela que o Brasil apostou nas assimetrias relacionais, isto é, em interações intergovernamentais adequadas, como meio hábil de concretizar o mandamento consignado no art. $3^{\circ}$, inciso III, da Lei 
Maior, que estabelece o dever de o Estado nacional criar programas que objetivem reduzir as desigualdades sociais e regionais. Alguns institutos constitucionais, a exemplo da possibilidade colocada à União para editar lei complementar que objetive disciplinar a cooperação entre os entes federados no exercício das competências comuns (art. 23, parágrafo único, da $\mathrm{CF}$ ), comprovam essa conclusão e ainda evidenciam que o poder central deve assumir o importante papel de coordenação e de planejamento dos instrumentos de compatibilização das disparidades regionais. Em igual direção, as regiões administrativas de desenvolvimento, previstas no art. 43 da Constituição, confirmam a orientação referida.

Nesse compasso, certamente algumas objeções podem ser colocadas em função do receio de que esse entendimento traduza-se, em termos práticos, em maior centralização política por parte da União. O risco, nunca descartável, de que a atuação do ente nacional na idealização dos mais destacados meios de superação dos problemas regionais redunde em maior centralização política por parte da União é notadamente enfraquecido por meio de um calibrado sistema de representação das unidades periféricas na formação das vontades e na execução das decisões do governo nacional. Por isso, talvez seja indicado afirmar que qualquer reforma na Federação, objetivando amainar os impactos que decorrem da diversidade político-territorial estampada em seus entes, tenha de começar pelos órgãos incumbidos da missão de possibilitar que a União atue em conformidade com as vontades de suas partes.

Percebe-se ainda que a última Constituinte, ao ter elevado os Municípios à condição de unidade autônoma, expôs o pacto federativo brasileiro com mais ênfase às fragilidades advindas da desigualdade territorial. O delicado problema de equacionar as diferenças para consecução de patamares sustentáveis de governabilidade, antes restrito às relações travadas entre União e Estados, ou entre estes, agora, atinge também os entes locais, que trazem entre si, como é sabido, disparidades absurdamente maiores que aquelas conformadas no plano estadual. Outra consequência da autonomia municipal está no fato de que muitas políticas públicas passaram a ser idealizadas com muito mais cuidado no que respeita à diversidade dos atores que irão participar do concerto a ser institucionalizado, haja vista que tanto as diferenças entre os Estados quanto os desníveis que se formam entre os Municípios deverão ser considerados a fim de não prejudicar a eficiência do programa estatal arranjado.

Frente a tudo o que foi considerado, é impossível negar o irrestrito interesse que o federalismo assimétrico desperta em matéria de ordenação do funcionamento do Estados 
compostos, na medida em que permite acomodar racionalmente as problemáticas desigualdades regionais, sempre causadoras de enfraquecimento ao pacto federativo e de ineficiência administrativa na prestação de serviços públicos. As assimetrias jurídicas, caso implantadas com consciência e em sintonia com as demandas requeridas pelo federalismo nacional, com certeza, irão trazer ganhos estruturais para a Federação como um todo. Sem privilégios e protecionismos, o ajuste das abissais diferenças regionais que tomam corpo diante de partes tão singulares parece passar obrigatoriamente pelo emprego das ferramentas ofertadas pela assimetria, uma vez que esse recurso figura como confiável promessa para diminuir os indesejados efeitos da desestabilização governamental, causados, em grande medida, pela insistência de remeter idêntico tratamento normativo a unidades territoriais demasiadamente diferentes.

Deve-se, portanto, ter convicção de que relações efetivamente balanceadas entre os sujeitos governamentais é o caminho a ser buscado para assegurar que os bemintencionados objetivos fundamentais da República possam ser corporificados de modo razoável. Inspirados nos princípios fundantes da Democracia Social, tais comandos programáticos dificilmente terão condições de serem materializados - ainda que em patamares mínimos -, enquanto a Federação continuar a sofrer sucessivos abalos decorrentes da acentuada diversidade interna observável do país. Nessa longa e cansativa empreitada, caberá, por certo, aos instrumentos assimétricos reorganizar o cenário federativo para que se possa, gradativamente, chegar ao tão almejado equilíbrio entre as partes federadas. E isso, de fato, apenas ocorrerá quando forem compreendidas e acomodadas as multifacetárias grandezas que condicionam a configuração assimétrica do federalismo brasileiro. 


\section{BIBLIOGRAFIA}

ABRANCHES, Sérgio, Presidencialismo de Coalização: O Dilema Institucional Brasileiro, in Dados, vol. 31, $\mathrm{n}^{\circ}$ 1, Rio de Janeiro, 1988, pp. 5-32.

ABRUCIO, Fernando Luiz, Os Barões da Federação: Os Governadores e a Redemocratização Brasileira, $2^{a}$ ed., São Paulo, Hucitec, 2002.

, Os Laços Federativos Brasileiros: Avanços, Obstáculos e Dilemas no Processo de Coordenação Intergovernamental, Tese de Doutorado, Faculdade de Filosofia, Letras e Ciências Humanas da USP, São Paulo, 2000.

ABRUCIO, Fernando Luiz; e COSTA, Valeriano Mendes Ferreira, Reforma do Estado e o Contexto Federativo Brasileiro, São Paulo, Fundação Konrad-Adenauer-Stiftung, 1999.

ACKERMAN, Bruce, Nós, o Povo Soberano: Fundamentos do Direito Constitucional, Belo Horizonte, Del Rey, 2006.

AFFONSO, Rui de Britto Álvares, A Federação na Encruzilhada, in Rumos: Caminhos do Brasil em Debate: Quem és tu, Federação? (publicação da Comissão Nacional para as Comemorações do V Centenário do Descobrimento do Brasil), São Paulo, ano 1, $\mathrm{n}^{\circ} 2$, mar./abr. 1999, pp. 29-38.

AFFONSO, Rui de Britto Álvares; e SILVA, Pedro Luiz Barros (org.), A Federação em Perspectiva: Ensaios Selecionados, São Paulo, FUNDAP, 1995.

AGRANOFF, Robert (ed.), Accommodating Diversity: Asymmetry in Federal States, Baden-Baden, Nomos, 1999.

ALESP (Assembleia Legislativa do Estado de São Paulo), Temas de Direito Constitucional Estadual e Questões sobre o Pacto Federativo, São Paulo, 2004.

ALMEIDA FILHO, Agassiz, Fundamentos do Direito Constitucional, Rio de Janeiro, Forense, 2007.

ALMEIDA, Fernanda Dias Menezes de, Atividade Constituinte nos Estados e nos Municípios, in Revista Jurídica "9 de Julho”, n 3, 2004, pp. 65-85.

2007.

, Competências na Constituição de 1988, $4^{\mathrm{a}}$ ed., São Paulo, Atlas,

, Considerações sobre o Rumo do Federalismo nos Estados Unidos e no Brasil, in Revista de Informação Legislativa, Brasília, ano 24, $\mathrm{n}^{\circ}$ 96, out./dez. 1987, pp. 57-64.

ALVES, Alaôr Caffé, Planejamento Metropolitano e Autonomia Municipal no Direito Brasileiro, São Paulo, José Bushatsky, 1981. 
ALVES, José Augusto Lindgren, Os Direitos Humanos como Tema Global, São Paulo, Perspectiva, 2007.

AMARAL FILHO, Antonio Sampaio, Regiões Metropolitanas, in Revista Trimestral de Direito Público, no 23, 1998, pp. 159-168.

ATALIBA, Geraldo, República e Constituição, $2^{\mathrm{a}}$ ed., São Paulo, Malheiros, 2004.

BACHUR, João Paulo, Federalismo Fiscal, Atribuições Fiscais Constitucionais e Equalização Regional: EUA, Alemanha e Brasil em Perspectiva Comparada, in Revista do Serviço Público, vol. 56, n 4, out/dez 2005, pp. 377-402.

BALEEIRO, Aliomar, Direito Tributário Brasileiro, $11^{\mathrm{a}}$ ed., Rio de Janeiro, Forense, 2003.

BARACHO, José Alfredo de Oliveira, O Princípio da Subsidiariedade: Conceito e Evolução, in Revista de Direito Administrativo, vol. 200, abr./jun. 1995, pp. 21-54.

Reengenharia do Estado (Aula Inaugural pronunciada na abertura do ano letivo de 1995, $2^{\circ}$ semestre, nos Cursos de Pós-Graduação em Direito da Universidade Gama Filho), Rio de Janeiro, Gamma, 1995.

FUMARC/UCMG, 1982.

Teoria Geral do Federalismo, Belo Horizonte,

BARBOSA, Rui, Comentários à Constituição Federal Brasileira, vol. I, São Paulo, Saraiva, 1932.

BARROS, Sérgio Resende de, Contribuição Dialética para o Constitucionalismo, Campinas, Millennium, 2008.

BARROSO, Luis Roberto, Direito Constitucional Brasileiro: O Problema da Federação, Rio de Janeiro, Forense, 1982.

BASTOS, Aureliano Cândido Tavares, A Província: Estudo sobre a Descentralização no Brasil, $3^{\mathrm{a}}$ ed., São Paulo, Editora Nacional, 1975.

BASTOS, Celso Ribeiro (coord.), Por uma Nova Federação, São Paulo, Revista dos Tribunais, 1995.

BASTOS, Celso Ribeiro, A Federação no Brasil, Brasília, Programa Nacional de Desburocratização e Instituto dos Advogados de São Paulo, 1985.

1994.

, Curso de Direito Constitucional, $15^{\mathrm{a}}$ ed., São Paulo, Saraiva, 
BASTOS, Celso Ribeiro; e MARTINS, Ives Gandra, Comentários à Constituição do Brasil: Promulgada em 5 de outubro de 1988, vol. 3, tomo III (Arts. 37 a 43), São Paulo, Saraiva, 1992.

BENZ, Arthur, From Unitary to Asymmetric Federalism in Germany: Taking Stock After 50 Years, in Publius, vol. 29, nº 4, Fall 1999, pp. 55-78.

BERCOVICI, Gilberto, Desigualdades Regionais, Estado e Constituição, São Paulo, Max Limonad, 2003.

Advogado, 2004.

Dilemas do Estado Federal Brasileiro, Porto Alegre, Livraria do

BITAR, Orlando, Obras Completas de Orlando Bitar: Estudos de Direito Constitucional e Direito do Trabalho, vol. 2, Rio de Janeiro, Renovar, 1996.

BOBBIO, Norberto, Da Estrutura à Função: Novos Estudos de Teoria do Direito, Barueri, Manole, 2007.

Os Intelectuais e o Poder: Dúvidas e Opções dos Homens de Cultura na Sociedade Contemporânea, São Paulo, Editora da Universidade Estadual Paulista, 1997.

BOBBIO, Norberto; MATTEUCI, Nicola; e PASQUINO, Gianfranco (coord.), Dicionário de Política, $7^{\text {a }}$ ed., Brasília, Editora Universidade de Brasília, 1995.

BONAVIDES, Paulo, A Constituição Aberta: Temas Políticos e Constitucionais da Atualidade, com ênfase no Federalismo das Regiões, $3^{\text {a }}$ ed., São Paulo, Malheiros, 2004.

2006.

Curso de Direito Constitucional, $18^{\mathrm{a}}$ ed., São Paulo, Malheiros,

Do Estado Liberal ao Estado Social, $8^{\mathrm{a}}$ ed., São Paulo, Malheiros,

2007.

BOWIE, Robert R. e FRIEDRICH, Carl. J., Estudios sobre Federalismo, Buenos Aires, Bibliográfica Argentina, 1958.

BRANCO, Álvaro Chagas Castelo, Paradiplomacia \& Entes Não-Centrais no Cenário Internacional, Curitiba, Juruá, 2008.

BRANCO, Marcello Simão, A Democracia Federativa Brasileira e o Papel do Senado no Ajuste Fiscal dos anos 90, Tese de Doutorado, Faculdade de Filosofia, Letras e Ciências Humanas da USP, São Paulo, 2007.

BRASIL, Diário da Assembleia Nacional Constituinte, Brasília, Senado Federal, Centro Gráfico, 1988. 
BRASIL, Anais do Senado Federal, vol. 4, Brasília, Senado Federal, 1997.

BRITTO, Carlos Ayres, Teoria da Constituição, Rio de Janeiro, Forense, 2003.

BUCCI, Maria Paula Dallari, Direito Administrativo e Políticas Públicas, São Paulo, Saraiva, 2002.

BULOS, Uadi Lammêgo, Constituição do Brasil Anotada, $7^{a}$ ed., São Paulo, Saraiva, 2007.

2007.

Curso de Direito de Direito Constitucional, São Paulo, Saraiva,

BURGESS, Michael; e GAGNON, Alain-G. (eds.), Comparative Federalism and Federation: Competing Traditions and Future Directions, Toronto; Buffalo, University of Toronto Press, 1993.

BURGUESS, Michael, Comparative Federalism: Theory and Practice, London, Routledge, 2006.

BUZAID, Alfredo, O Estado Federal Brasileiro, Brasília, Ministério da Justiça, 1971.

CAAMAÑO, Francisco, "Federalismo Assimétrico": La Impossible Renuncia al Equilíbrio, in Revista Española de Derecho Constitucional, no 55, ano 19, pp. 359363.

CADEMARTORI, Sergio, Estado de Direito e Legitimidade - uma Abordagem Garantista, $2^{\mathrm{a}}$ ed., Campinas, Millennium, 2006.

CAETANO, Marcelo, Direito Constitucional - vol. II: Direito Constitucional Brasileiro, Rio de Janeiro, Editora Forense, 1978.

CALMON, Pedro, Curso de Direito Público, Rio de Janeiro, Freitas Bastos, 1938.

CALOGERAS, João Pandiá, Formação Histórica do Brasil, Rio de Janeiro, Pimenta de Mello, 1930.

CAMARGO, Aspásia, A Reforma-Mater: Os Riscos (e os Custos) do Federalismo Incompleto, in Parcerias Estratégicas, $\mathrm{n}^{\circ}$ 6, mar. 1999, pp. 80-109.

, O Novo Pacto Federativo, in Revista do Serviço Público, ano 45, vol. 118, nº 1, jan./jul. 1994, pp. 87-94.

CAMINAL, Miquel, El Federalismo Pluralista: del Federalismo Nacional al Federalismo Plurinacional, Barcelona, Paidós, 2002.

CANOTILHO, José Joaquim Gomes, Direito Constitucional e Teoria da Constituição, $7^{\mathrm{a}}$ ed., Coimbra, Almedina, 2003. 
Rever ou Romper com a Constituição Dirigente? Defesa de um Constitucionalismo Moralmente Reflexivo, in Cadernos de Direito Constitucional e Ciência Política, ano 4, no 15, abr./jun. de 1996, pp. 7-17.

CARLONI, Enrico, Lo Stato Differenziato: Contributo allo Studio dei Principi di Uniformità e Differenziazione, Torino, G. Giappichelli, 2004.

CARRÉ DE MARBERG, R., Teoría General del Estado, México, Facultad de Derecho/Unam e Fondo de Cultura Económica, 2001.

CARVAlHO, José Murilo de, A Construção da Ordem: a Elite Política imperial. Teatro das Sombras: a Política Imperial, Rio de Janeiro, Civilização Brasileira, 2003.

CHAVÉZ, , Alicia Hernández (coord.), ¿Hacia um Nuevo Federalismo?, México, Fondo de Cultura, 1996.

CHIEFFI, Lorenzo (org.), I Diritti Sociali tra Regionalismo e Prospettive Federali, Padova, CEDAM, 1999.

CHUST, Manuel (ed.), Federaismo y Cuestión Federal en España, Castelló de la Plana, Publicacions de la Universitat Jaume I, 2004.

CONTI, Maurício (org.), Federalismo Fiscal, Barueri, Manole, 2004.

CORNELl, Svante E., Autonomy as a Source of Conflict: Caucasian Conflicts in Theoretical Perspective, in World Politics, vol. 54, $\mathrm{n}^{\mathrm{o}}$ 2, jan. 2002, pp. 245-276.

COSTA, Elcias Ferreira da, Comentários Breves à Constituição Federal, Porto Alegre, Sergio Antonio Fabris Editor, 1989.

COSTA, Wilma Peres da, A Questão Fiscal na Transformação Republicana Continuidade e Descontinuidade, in Economia e Sociedade, Campinas, $\mathrm{n}^{\mathrm{o}}$ 10, jun. 1998, pp. 141-174.

CRETELLA JÚNIOR, José, Comentários à Constituição Brasileira de 1988, vols. 3 e 5, Rio de Janeiro, Forense Universitária, 1991.

CRUZ VILlALON, Pedro, Dos cuestiones de Titularidad de Derechos: Los Extranjeros; Las Personas Jurídicas, in Revista Española de Derecho Constitucional, ano 12, ${ }^{\circ}$ 35, may./agos. 1992, pp. 63-83.

CUNHA, Fernando Whitaker da, Direito Político Brasileiro, Rio de Janeiro, Forense, 1978.

DAHL, Robert A., Sobre a Democracia, Brasília, Editora Universidade de Brasília, 2001.

How Democratic is the American Constitution?, $2^{\mathrm{a}}$ ed., Yale University Press, 2003. 
DALlARI, Dalmo de Abreu, Constituição e Constituinte, $3^{\text {a }}$ ed., São Paulo, Saraiva, 1986.

Saraiva, 2009. Elementos de Teoria Geral do Estado, 28ª ed., São Paulo, , O Estado Federal, São Paulo, Ática, 1986. , Os Estados na Federação Brasileira, de 1891 a 1937, in Revista de Direito Constitucional e Ciência Política, ano 2, no 3, jul. 1984, pp. 100-140.

DALLARI, Sueli Gandolfi, Os Estados Brasileiros e o Direito à Saúde, São Paulo, Hucitec, 1995.

DANTAS, Ivo, Direito Constitucional Comparado, vol. 1, 2 a ed., Rio de Janeiro, Renovar, 2006.

DAVID, René, Os Grandes Sistemas do Direito Contemporâneo, São Paulo, Martins Fontes, 2002.

DI PIETRO, Maria Sylvia Zanella, Direito Administrativo, 21ª ed., São Paulo, Atlas, 2008.

DIAS, Edna Cardozo, Regiões Metropolitanas, in Fórum de Direito Urbano e Ambiental (FDUA), ano 7, no 37, jan./fev. 2008, pp. 15-20.

DIPPEL, Horst, História do Constitucionalismo Moderno: Novas Perspectivas, Lisboa, Fundação Calouste Gulbenkian, 2007.

DOLHNIKOFF, Miriam, O Pacto Imperial: Origens do Federalismo no Brasil do Século XIX, São Paulo, Globo, 2005.

DÓRIA, A. de Sampaio, Direito Constitucional, vol $1^{o}$, tomo II, $4^{\mathrm{a}}$ ed., São Paulo, Max Limonad, 1958.

, Direito Constitucional, vol. $2^{o}$ : Comentários à Constituição de 1946: Arts. $1^{\circ}$ a 77, São Paulo, Max Limonad, 1960.

ELAZAR, Daniel J., Exploring Federalism, Tuscaloosa, The University of Alabama Press, 1987.

FAORO, Raymundo, Assembleia Constituinte: A Legitimidade Recuperada, $5^{\mathrm{a}}$ ed., São Paulo, Brasiliense, 1986.

Paulo, Globo, 2001.

Os Donos do Poder: Formação do Patronato Político, $3^{\mathrm{a}}$ ed., São

FARIA, José Eduardo Campos de Oliveira, Legalidade e Legitimidade: A Reordenação Institucional do País, in Revista de Direito Constitucional e Ciência Política, ano 3, $\mathrm{n}^{\mathrm{o}}$ 4, jan./jun. de 1985, pp. 48-59. 
FERNÁNDEZ MANJÓN, Desiderio, Desafios de la Diversidad Territorial en los Estados Compuestos Asimétricos, Barcelona, Fundación "la Caixa", 2001.

La Colaboración en el Estado Compuesto Asimétrico: El Caso de España, Oñati, IVAP, 2001.

FERNÁNDEZ SEGADO, FRANCISCO, El Bicameralismo y la Naturaleza del Senado, in Revista Española de Derecho Constitucional, ano 2, nº 6, 1982, pp. 61-114.

La Dimensión Axiológica del Derecho Constitucional, in Cuadernos Constitucionales de la Cátedra Fadrique Furió Ceriol, nº 1, 1992, pp. 15-39.

FERRANDO BADIA, Juan, El Estado Unitario, el Estado Federal y el Estado Autonomico, Madrid, Tecnos, s/d.

1976, pp. 23-76.

, El Federalismo, in Revista de Estudios Políticos, $\mathrm{n}^{\mathrm{o}}$ 206-207,

FERRAZ JÚNIOR, Tércio Sampaio, Litígio Constitucional entre Estados-membros e a Competência do STF, in Revista de Direito Administrativo, no 194, out./dez. 1993, Rio de Janeiro, pp. 6-11.

FERREIRA FILHO, Manoel Gonçalves, A Democracia Possível, $2^{\mathrm{a}}$ ed., São Paulo, Saraiva, 1974.

Saraiva, 2003.

, Aspectos do Direito Constitucional Contemporâneo, São Paulo,

, Constituição e Governabilidade: Ensaio sobre a

(In)governabilidade Brasileira, São Paulo, Saraiva, 1995.

2009.

, Curso de Direito Constitucional, $35^{\mathrm{a}}$ ed., São Paulo, Saraiva, , O Poder Constituinte, $3^{\text {a }}$ ed., São Paulo, Saraiva, 1999.

FERREIRA, Pinto, Comentários à Constituição Brasileira, vol. $2^{o}$, Arts. 22 a 53, São Paulo, Saraiva, 1990.

Saraiva, 1995.

Curso de Direito Constitucional, $7^{\mathrm{a}}$ ed., São Paulo, Editora

Princípios Gerais do Direito Constitucional Moderno, tomo I, $2^{\mathrm{a}}$ ed., Rio de Janeiro, José Konfino, 1954.

FLEURY, Sonia (org.), Democracia, Descentralização e Desenvolvimento: Brasil $e$ Espanha, Rio de Janeiro, FGV, 2006. 
FOSSAS, Enric e REQUEJO, Ferran (eds.), Asimetría Federal y Estado Plurinacional: El Debate sobre la Acomodación de la Diversidad en Canadá, Bélgica y España, Madrid, Trotta, 1999.

FRANCO, Afonso Arinos de Melo, Curso de Direito Constitucional, vol. I: Teoria da Constituição; as Constituições do Brasil, Rio de Janeiro, Revista Forense, 1958.

Janeiro, 1957.

, Estudos de Direito Constitucional, Revista Forense, Rio de

FURTADO, Celso, A Federação por Fazer, in Rumos: Caminhos do Brasil em Debate: Quem és tu, Federação? (publicação da Comissão Nacional para as Comemorações do V Centenário do Descobrimento do Brasil), São Paulo, ano 1, $\mathrm{n}^{\circ}$ 2, mar./abr. 1999, pp. 39-41.

GAGNON, Alain-G., Quebec y el Federalismo Canadiense, Madrid, Consejo Superior de Investigaciones Científicas, Instituto de Estudios Sociales Avanzados, 1998.

GARCIA, Maria Glória E. P. D., Estudos sobre o Princípio da Igualdade, Coimbra, Almedina, 2005.

GARCIA-PELAYO, Manuel, As Transformações do Estado Contemporâneo, Rio de Janeiro, Forense Universitária, 2009.

, Derecho Constitucional Comparado, $3^{\mathrm{a}}$ ed., Madrid, Manuales de la Revista de Occidente, 1953.

GARSON, Sol, Regiões Metropolitanas: Por que não Cooperam?, Rio de Janeiro, Letra Capital; e Belo Horizonte, Observatório das Metrópoles, 2009.

GAUDREAULT-DESBIENS, Jean-François, Federalismo y Democracia, in Boletín Mexicano de Derecho Comparado, Nueva Serie, ano XXXIX, $\mathrm{n}^{\circ} 117$, sep./dic., 2006, pp. 671-692.

GODOY ARCAYA, Oscar, Republicanismo, Liberalismo y Democracia, in Estudios Públicos, $\mathrm{n}^{\circ}$ 99, 2005, pp. 241-256.

GÓMEZ MONTORO, Ángel J., La Titularidad de Derechos Fundamentales por Personas Jurídicas: un Intento de Fundamentación, in Revista Española de Derecho Constitucional, ano 22, $\mathrm{n}^{\mathrm{o}}$ 65, may./agos. 2002, pp. 49-105.

GONZÁLEZ ADÁNEZ, Noelia, Liberalismo, Republicanismo y Monarquía Absoluta: los Proyectos de Reforma para América en la Segunda Mitad del Siglo XVIII Español, in Revista de Estudios Políticos, nº 113, 2001, pp. 359-369.

GRAU, Eros Roberto, Regiões Metropolitanas: Regime Jurídico, São Paulo, José Bushatsky, 1974. 
GRIMM, Dieter, Constituição e Política, Belo Horizonte, Del Rey, 2006.

HÄBERLE, Peter, Comparacíon Constitucional y Cultural de los Modelos Federales, in Revista de Derecho Constitucional Europeo, no 8, jul./dic. 2007, pp. 171-188.

HAMILTON, Alexander; MADISON, James e JAY, John, O Federalista, Brasília, Editora Universidade de Brasília, 1984.

HAMON, Francis; TROPER, Michel; e BURDEAU, Georges, Direito Constitucional, Barueri, Manole, 2005.

HELly, Denise, Primacía de los Derechos o Cohésion Social: los Limites del Multiculturalismo Canadiense, in Acciones e Investigaciones Sociales, $\mathrm{n}^{\mathrm{o}} 15$, out. 2002, pp. 5-28.

HESSE, Konrad, El Estado Federal Unitario, in Revista de Derecho Constitucional Europeo, $\mathrm{n}^{\circ}$ 6, jul./dic. 2006, pp. 425-456.

Elementos de Direito Constitucional da República Federal da Alemanha, Porto Alegre, Sérgio Antonio Fabris Editor, 1998.

HICKS, Ursula K., Federalism: Failure and Sucess, New York, Oxford University Press, 1978.

HILHORST, Jos G. M., Planejamento Regional: Enfoque sobre Sistemas, $2^{\mathrm{a}}$ ed., Rio de Janeiro, Zahar, 1973.

HOBSBAWM, Eric J., Nações e Nacionalismo desde 1870, $3^{\mathrm{a}}$ ed., Rio de Janeiro, Paz e Terra, 2002.

HORN, Hans-Rudolf, Aspectos Sociales Intrínsecos del Derecho Contemporâneo, in Cuestiones Constitucionales: Revista Mexicana de Derecho Constitucional, $\mathrm{n}^{\mathrm{o}}$ 5, 2001, p. 145-171.

HORTA, Raul Machado, Direito Constitucional, $3^{\text {a }}$ ed., Belo Horizonte, Del Rey, 2002.

HORTA, Raul Machado, Tendências Atuais da Federação Brasileira, in Cadernos de Direito Constitucional e Ciência Política, ano 4, nº 16, jul/set de 1996.

IBDC (Instituto Brasileiro de Direito Constitucional) (coord.), 10 anos de Constituição, São Paulo, Celso Bastos Editor, 1998.

INAP (Instituto Nacional de Administración Pública), Asimetría y Cohesión en el Estado Autonómico: Jornadas sobre el Estado Autonómico: Integración y Eficacia, Madrid, Ministerio de Administraciones Públicas, 1997.

JARDIM, Torquato, A Tridimensionalidade da Descentralização do Estado Brasileiro, in Revista de Informação Legislativa, Brasília, ano 31, n 122, mai.jul. 1994, 
JEFFERY, Charlie (ed.), Recasting German Federalism: The Legacies of Unification, London, Pinter, 1999.

JELLINEK, Georg, Teoria General del Estado, Buenos Aires, Editorial Albatroz, 1973.

KARMIS, Dimitrios e NORMANN, Wayne (eds.), Theories of Federalism: A Reader, New York, Palgrave Macmillan, 2005.

KATZ, Ellis; e TARR, Alan (eds.), Federalism and Rigths, Boston, Rowman \& Littlefield Publishers, 1996.

KAUFMANN, Arthur, Filosofia do Direito, Lisboa, Fundação Calouste Gulbenkian, 2004.

KING, Preston, Federalism and Federation, Baltimore, The Johns Hopkins University Press, 1982.

KUGELMAS, Eduardo; e SOLA, Lourdes, Construcción del Federalismo Democrático en Brasil, in ICE: Revista de Economía, nº 810, 2003, pp. 105-122.

LASSALE, Ferdinand, Que é uma Constituição?, Porto Alegre, Villa Martha, 1980.

LEAL, Victor Nunes, Coronelismo, Enxada e Voto, $5^{\text {a }}$ ed., São Paulo, Alfa-Omega, 1986.

LENDVAI, Paul, Yugoslavia without Yugoslavs: The Roots of the Crisis, in International Affairs, vol. 67, n 2, apr. 1999, pp. 251-261.

LOEWENSTEIN, Karl, Teoria de la Constitución, Barcelona, Ariel, 1976.

LOPES, José Reinaldo Lima, Direito e Transformação Social: Ensaio Interdisciplinar das Mudanças do Direito, Belo Horizonte, Nova Alvorada, 1997.

LÓPEZ-JURADO ESCRIBANO, Francisco de Borja, La Doctrina del Tribunal Constitucional Federal Alemán sobre los Derechos Fundamentales de las Personas Juridico-Publicas: su Influencia sobre nuestra Jurisprudencia Constitucional, in Revista de Administración Pública, nº 125, may./agos. 1991, pp. 557-573.

LUCAS VERDÚ, Pablo, O Sentimento Constitucional: Aproximação ao Estudo do Sentir Constitucional como Modo de Integração Política, Rio de Janeiro, Forense, 2004. Principios de Ciencia Política, Tomo I, $3^{\mathrm{a}}$ ed., Madrid, Tecnos, 1973.

MAGALHÃES, José Luiz Quadros (coord.), Pacto Federativo, Belo Horizonte, Mandamentos, 2000.

MÁIZ SUÁREZ, Ramón, Federalismo Plurinacional: Una Teoria Política Normativa, in Revista d'Estudis Autonòmics i Federals, nº 3, 2006, pp. 43-85. 
MARINHO, Josaphat, Direito, Sociedade \& Estado, Salvador, Memorial das Letras, 1998.

MARTINS, Cristiano Franco, Princípio Federativo e Mudança Constitucional: Limites e Possibilidades na Constituição de 1998, Rio de Janeiro, Lumen Juris, 2003.

MARTINS, Ives Gandra (coord.), A Constituição Brasileira 1988: Interpretações, Rio de Janeiro, Forense Universitária, 1988.

MARTINS, Ives Gandra; e REZEK, Francisco (coord.), Constituição Federal: Avanços, Contribuições e Modificações no Processo Democrático Brasileiro, São Paulo, Centro de Extensão Universitária e Revista dos Tribunais, 2008.

MARTINS, Waldemar Ferreira, História do Direito Constitucional Brasileiro, São Paulo, Max Limonad, 1954.

MAURER, Hartmut, Contributos para o Direito do Estado, Porto Alegre, Livraria do Advogado, 2007.

MAXIMILIANO, Carlos, Hermenêutica e Aplicação do Direito, 19ª ed., Rio de Janeiro, Forense, 2009.

MEIRELLES, Hely Lopes, Direito Municipal Brasileiro, $15^{\mathrm{a}}$ ed., São Paulo, Malheiros, 2007.

MELlO, Celso Antonio Bandeira de, Conteúdo Jurídico do Princípio da Igualdade, $3^{\mathrm{a}}$ ed., São Paulo, Malheiros, 2009.

MELLO, José Luiz de Anhaia, O Estado Federal e suas Novas Perspectivas, São Paulo, Max Limonad, 1960.

MELLO, Oswaldo Aranha Bandeira de, Natureza Jurídica do Estado Federal, São Paulo, Prefeitura do Município de São Paulo, 1948.

MELlO, Oswaldo Ferreira de, Tendências do Federalismo no Brasil, Florianópolis, Lunardelli, s/d.

MENDES, Gilmar Ferreira, COELHO Inocêncio Mártires e BRANCO, Paulo Gustavo Gonet, Curso de Direito Constitucional, $4^{\text {a }}$ ed., São Paulo, Saraiva, 2009.

MENEZES, Anderson de, Teoria Geral do Estado, 8ª ed., Rio de Janeiro, Forense, 1999.

MINITTI, Silene Pinheiro Cruz, As Relações Fiscais Intergovernamentais nas Constituições Brasileiras, Tese de Doutorado, Faculdade de Direito da USP, São Paulo, 2004.

MIRANDA, Jorge, Manual de Direito Constitucional, Tomo IV, $3^{\text {a }}$ ed., Coimbra, Coimbra Editora, 2000. 
Teoria do Estado e da Constituição, Rio de Janeiro, Forense,

2007.

MONREAL, Antoni (ed.), El Estado de las Autonomias, Madrid, Tecnos, 1991.

MORAES, Alexandre de, Constituição do Brasil Interpretada e Legislação Constitucional, $6^{a}$ ed., São Paulo, Atlas, 2007.

MORBIDELLI, Janice Helena Ferreri, Um Novo Pacto Federativo para o Brasil, São Paulo, Celso Bastos Editor, Instituto Brasileiro de Direito Constitucional, 1999.

MOREIRA NETO, Diogo Figueiredo, A Revisão Constitucional Brasileira: Como se Situa, qual seu Alcance e quais seus Limites, Rio de Janeiro, Lumen Juris, 1993.

, Parecer: O Tribunal de Contas do Município do Rio de Janeiro e a Emenda Constitucional $n^{\circ}$ 25/2000, in Revista Direito, Rio de Janeiro, vol. 5, $\mathrm{n}^{\circ} 9$, jan./jun. 2001, pp. 15-50.

MOREIRA, Alexandre Mussoi, A Transformação do Estado: Neoliberalismo, Globalização e Conceitos Jurídicos, Porto Alegre, Livraria do Advogado, 2002.

MOUSKELI, M., Teoria Jurídica del Estado Federal, México D.F., Editora Nacional, 1981.

NAGEL, Klaus-Jürgen, El Federalismo Alemán. ¿ Más Cooperación o Nueva Asimetría?, in Revista de Estudios Políticos, nº 118, oct./dic. 2002, pp. 65 -99.

NEVES, Marcelo, Transconstitucionalismo, São Paulo, WMF Martins Fontes, 2009.

NICE, David C., Federalism: The Politics of Intergovernamental Relations, New York, St. Martin's Press, 1987.

NOBRE JÚNIOR, Edílson Pereira, Administração Pública e o Princípio Constitucional da Eficiência, in Revista Trimestral de Direito Público, n 44, out./dez. 2003, pp. 67-92.

NOGUEIRA, Octaciano, Doutrina Constitucional Brasileira (Constituição de 1946), vol. 1, Brasília, Senado Federal, 2006.

NUNES, José de Castro, Do Estado Federado e sua Organização Municipal, Brasília, Câmara dos Deputados, 1982.

PACHECO, Cláudio, Tratado das Constituições Brasileiras, vol. I, Rio de Janeiro, Freitas Bastos, 1958.

PAUPÉRIO, A. Machado, O Município e seu Regime Jurídico no Brasil, $2^{\mathrm{a}}$ ed., Rio de Janeiro, Forense, 1973. 
PEGORARO, Lucio, El Método en el Derecho Constitucional: la Perspectiva desde el Derecho Comparado, in Revista de Estudios Políticos (Nueva Época), $\mathrm{n}^{\circ} 112$, abr./jun. 2001, pp. 9-26.

PEIXOTO, Fábio Cirino, Teóricos da Véspera: o Federalismo no Pensamento Político do Brasil Império, Dissertação de Mestrado, Faculdade de Filosofia, Letras eCiências Humanas da USP, São Paulo, 2005.

PELlEGRINO, Carlos Roberto, Compromisso Constituinte, in Revista de Informação Legislativa, Brasília, ano 24, nº 96, out./dez. 1987, pp. 31-40.

PERNTHALER, Peter, Lo Stato Federale Differenziato: Fundamenti Teorici, Conseguenze Pratiche ed Ambiti Applicativi nella Riforma del Sistema Federale Austríaco, Bologna, Il Mulino, 1998.

PNUD (Programa das Nações Unidas para o Desenvolvimento), Relatório do Desenvolvimento Humano 2004: Liberdade Cultural num Mundo Diversificado, Sakiko Fukuda-Parr (coord.), Lisboa, Mensagem Serviços de Recursos Editoriais, 2004.

PONTES DE MIRANDA, Francisco Cavalcanti, Comentários à Constituição da República dos E. U. do Brasil, tomo I, artigos 1-103, Rio de Janeiro, Guanabara, 1936.

RAMELlA, Pablo A., Replanteo del Federalismo, Buenos Aires, Depalma, 1971.

RAMOS, Dircêo Torrecillas, O Federalismo Assimétrico, 2ª ed., São Paulo, Forense, 2000.

RANIERI, Nina, Sobre o Federalismo e o Estado Federal, in Cadernos de Direito Constitucional e Ciência Política, ano 3, nº 9, out./dez. de 1994, pp. 87-98.

REALE, Miguel, Da Democracia Liberal à Democracia Social, in Revista de Direito Público, no 71, pp. 23-39.

Lições Preliminares de Direito, 27ª ed., São Paulo, Saraiva, 2009.

REZENDE, Fernando (coord.), Desafios do Federalismo Fiscal, Rio de Janeiro, FGV, 2006.

REZENDE, Flávio Cunha, Por Que Falham as Reformas Administrativas?, Rio de Janeiro, Editora FGV, 2004.

ROCHA, Carmén Lúcia Antunes, República e Federação no Brasil: Traços Constitucionais da Organização Política Brasileira, Belo Horizonte, Del Rey, 1996.

ROMERO GONZÁLEZ, Juan, El Gobierno del Territorio en España. Balance de Iniciativas de Coordenacion y Cooperacíon Territorial, in Boletín de la A.G.E., $\mathrm{n}^{\mathrm{o}}$ 39, 2005, pp. 59-86. 
ROVIRA, Enoch Alberti, El Federalismo Actual como Federalismo Cooperativo, in Revista Mexicana de Sociología, vol. 58, n 4, oct./dec., 1996, pp. 51-68.

RUFFIA, Paolo Biscaretti de, Introducción al Derecho Constitucional Comparado y 19881990. Un Trienio de Profundas Transformaciones Constitucionales em Ocidente, en la URSS y los Estados Socialistas del Leste Europeu, México, Fondo de Cultura Económica, 1996.

RUSSOMANO, Rosah, Princípio do Federalismo na Constituição Brasileira, Rio de Janeiro, Freitas Bastos, 1965.

SABOIA, Marcelo Rocha, Notas Sobre as Regiões Metropolitanas, in Revista de Informação Legislativa, ano 35, $\mathrm{n}^{\mathrm{o}}$ 138, abr.jun. 1998, pp. 231-236.

SARTORI, Giovanni, La Ingeniería Constitucional y sus Limites, in Teoría y Realidad Constitucional, $\mathrm{n}^{\mathrm{o}}$ 3, 1999, pp. 79-87.

São Paulo, Ática, 1994.

Teoria Democrática Revisitada, vol. II: As Questões Clássicas,

SCHIMITT, Carl, Legalidade e Legitimidade, Belo Horizonte, Del Rey, 2007.

s/d.

, Teoria de la Constituición, Madrid, Revista de Derecho Privado,

SCHUBERT, Klaus, Federalismo. Entre Política y Ciencia, in Revista de Estudios Políticos, no 96, 1997, pp. 163-174.

SCHWARTZ, Bernard, $O$ Federalismo Norte-Americano Atual: Uma Visão Contemporânea, Rio de Janeiro, Forense Universitária, 1984.

SEIJAS VILLADANGOS, Esther, Configuración Asimétrica del Sistema de Comunidades Autónomas, vols. 1 e 2, Léon, Universidad de Léon, Secretariado de Publicaciones y Medios Audiovisuales, 2003.

SEN, Amartya Kumar, Desenvolvimento como Liberdade, São Paulo, Companhia das Letras, 2000.

SERRANO, Pedro Estevam Alves Pinto, Região Metropolitana e seu Regime Constitucional, São Paulo, Verbatim, 2009.

SILVA, Enio Moraes da, O Estado Democrático de Direito, in Revista de Informação Legislativa, Brasília, ano 42, nº 167, jul./set. 2005, pp. 213-229.

SILVA, José Afonso da, Comentário Contextual à Constituição, $3^{\mathrm{a}}$ ed., São Paulo, Saraiva, 2007. 
Constituinte: Caminho para uma Nova Ordem Constitucional, in Estudos Legislativos, ano 3, no especial, 2009, pp. 21-46.

$32^{\mathrm{a}}$ ed., 2009. Curso de Direito Constitucional Positivo, São Paulo, Malheiros, Um Pouco de Direito Constitucional Comparado (Apêndice: Três Projetos de Constituição), São Paulo, Malheiros. 2009.

SILVEIRA, Alessandra, Cooperação e Compromisso Constitucional nos Estados Compostos, Coimbra, Almedina, 2007.

SILVEIRA, Rosa Maria Godoy, Republicanismo e Federalismo: um Estudo da Implantação da República Brasileira (1889-1902), Brasília, Senado Federal, 1978.

SLAIBI FILHO, Nagib (coord.), Revista Forense Comemorativa - 100 anos, v. 1, Rio de Janeiro, Forense, 2005.

SOARES, Márcia Miranda, Teoria do Sistema Federal: Heterogeneidades Territoriais, Democracia e Instituições Políticas, Dissertação de Mestrado, Faculdade deFilosofia e Ciências Humanas da UFMG, 1997.

SOBRINHO, Manoel de Oliveira Franco, Regimes Políticos: Subsídios para Processo de Reorganização Política Nacional. Uma Constituição para o Brasil, Rio de Janeiro, Forense, 1984.

SOUZA JUNIOR, Cezar Saldanha e AVILA, Marta Marques (coord.), Direito do Estado Estudos sobre Federalismo, Porto Alegre, Dora Luzzatto, 2007.

SOUZA JUNIOR, Cezar Saldanha, Consenso e Constitucionalismo no Brasil, Porto Alegre, Sagra Luzzatto, 2002.

SOUZA NETO, Cláudio Pereira ; SARMENTO, Daniel; e BINENBOJM, Gustavo (coord.), Vinte Anos da Constituição Federal de 1988, Rio de Janeiro, Lumen Juris, 2009.

SOUZA, Celina, Federalismo e o Gasto Social no Brasil: Tensões e Tendências, in Lua Nova, $\mathrm{n}^{\circ} 52,2001$, pp. 5-28.

STEVENS, R. Michael, Asymmetrical Federalism: The Federal Principle and The Survival of the Small Republic, in Publius, 7:4, Fall 1977, pp. 177-204.

STRECK, Lenio Luiz e MORAIS, José Luiz Bolzan de, Ciência Política e Teoria do Estado, 6 ${ }^{\mathrm{a}}$ ed., Porto Alegre, Livraria do Advogado, 2008.

TARLTON, Charles D., Symmetry and Asymmetry as Elements of Federalism: a Theoretical Speculation, in The Journal of Politics, vol. 27, $\mathrm{n}^{\mathrm{o}}$ 1, feb. 1965, pp. 861874. 
TAVARES, André Ramos; MENDES, Gilmar Ferreira; e MARTINS, Ives Gandra da Silva (coord.), Lições de Direito Constitucional em Homenagem ao Jurista Celso Bastos, São Paulo, Saraiva, 2005.

TEIXEIRA, J. H. Meirelles, Curso de Direito Constitucional, Rio de Janeiro, Forense Universitária, 1991.

TEMER, Michel, Elementos de Direito Constitucional, 22a ed., São Paulo, Malheiros, 2008.

TEPEDINO, Gustavo, Temas de Direito Civil, $3^{\mathrm{a}}$ ed., Rio de Janeiro, Renovar, 2004.

THÉRET, Bruno, O Federalismo como Princípio de Regulação do Regionalismo. Uma Análise dos Programas de Perequação Destinados a Compensar as Desigualdades Inter-regionais na América do Norte (Canadá-EUA), in Contexto Internacional, vol. 20, no 1 , pp. 107-184.

TOCQUEVILlE, Alexis de, A Democracia na América, Livro 1: Leis e Costumes, São Paulo, Martins Fontes, 2005.

TORRES, João Camillo de Oliveira, A Formação do Federalismo no Brasil, São Paulo, Companhia Editora Nacional, 1961.

TORRES, Ricardo Lobo, O Princípio da Transparência no Direito Financeiro, in Revista de Direito da Associação dos Procuradores do Novo Estado do Rio de Janeiro, Rio de Janeiro, Lumen Juris, 2001, pp. 133-156.

TRUYOL Y SERRA, Antonio, La Representación Ponderada y su Aplicación em Federalismo Germano, in Revista de Política Internacional, nº 162, 1979, pp. 7-41.

VALADÉS, Diego e SERNA DE LA GARZA, José María (coord.), Federalismo y Regionalismo, México, Universidad Nacional Autónoma de México, 2005.

VARELA, Alfredo, Direito Constitucional Brasileiro: Reforma das Instituições Nacionais, $2^{a}$ ed., Rio de Janeiro, Livraria H Garnier, 1902.

VARSANO, Ricardo, A Guerra Fiscal do ICMS: Quem Ganha e Quem Perde, in Planejamento e Políticas Públicas, nº 15, jun. 1997, pp. 3-18.

VERGOTTINI, Giuseppe de, Diritto Constitucionale Comparato, $2^{\mathrm{a}}$ ed., Padova, CEDAM, 1987.

VIANA, Victor, A Constituição dos Estados Unidos: As Lições de uma Longa Experiência - Federalismo Norte-americano e Federalismo Brasileiro, Rio de Janeiro, Jornal do Comércio, 1933.

VIANNA, Oliveira, Evolução do Povo Brasileiro, $3^{\text {a }}$ ed., Rio de Janeiro, Editora Nacional, 1938. 
VILANOVA, Lourival, As Estruturas Lógicas e o Sistema do Direito Positivo, São Paulo, Revista dos Tribunais, 1977.

WATTS, Ronald L., Comparing Federal Systems, $2^{\text {a }}$ ed., Ontario, Institute of Intergovernmental Relations, 1999.

New Federations: Experiments in the Commonwealth, London, Oxford University Press, 1966.

ZIMMERMANN, Augusto, Teoria Geral do Federalismo Democrático, $2^{\mathrm{a}}$ ed., Rio de Janeiro, Lumen Juris, 2005. 


\section{RESUMO}

A difícil missão de compatibilizar as diversidades regionais demanda múltiplos esforços por parte daqueles envolvidos na construção das estruturas jurídicas que sustentam os pactos federativos estabelecidos nas várias Federações do mundo. Esse dado é verificado, numa intensidade evidentemente maior, em países como o Brasil, onde as desigualdades regionais não apenas diferenciam os entes federados, mas são a causa de conflitos que, inclusive, podem os contrapor, a exemplo dos episódios de guerra fiscal.

Busca-se, nesta dissertação, mapear os principais mecanismos consignados na atual ordem constitucional e que podem ser utilizados na harmonização dos complicados pontos de tensão decorrentes das diferenças que há entre as unidades político-administrativas das diferentes regiões do país. Anote-se, ainda, que a acentuação das práticas de cooperação intergovernamental, notadamente em matéria de planejamento de políticas públicas, torna o tema aqui estudado interessante para o constitucionalismo pátrio, pois o sucesso das ações governamentais desenvolvidas nessa área depende diretamente do acerto na equação entre os deveres prestacionais e as reais possibilidades de execução das funções destinadas a cada um dos entes federados.

Para tanto, são adotadas duas linhas de abordagem. A primeira, concentrada na apreciação crítica dos aspectos jurídicos da teoria do Estado federal assimétrico, investiga as tipologias de assimetria, bem como as consequências que podem ser carreadas pela aplicação concreta das assimetrias de direito em Estados territoriais compostos; além disso, tomando-se como foco os entes autônomos, são apresentados os possíveis contornos do princípio da igualdade no cenário federativo. A outra, por sua vez, adota como proposta a análise de aspectos fáticos (fatores históricos, socioeconômicos, geográficos e políticos) ligados ao Estado nacional, para justificar a necessidade de aplicação dos paradigmas inerentes ao federalismo assimétrico no funcionamento de nossa Federação.

Assim é que, depois de certificadas que algumas heterogeneidades presentes, no ambiente no qual o Estado federal brasileiro se edificou, ocasionam problemáticos reflexos ao incremento das relações intergovernamentais, são apresentadas, por último, perspectivas para o adequado manuseio das competências constitucionais comuns e para a criação de regiões metropolitanas e de regiões de desenvolvimento, com vistas a permitir o enquadramento da Federação nacional dentro dos valores que informam o federalismo assimétrico. 


\section{PALAVRAS-CHAVE}

Federalismo Assimétrico, Federalismo, Estado Federal, Assimetria, Desigualdades Regionais, Cooperação Intergovernamental. 


\section{RIASSUNTO}

Il difficile compito di conciliare le diversità regionali demanda multipli sforzi dalla parte di chi è coinvolto nella costruzione delle strutture giuridiche che sostengono i patti federativi stabiliti nelle diverse Federazioni del mondo. Ciò si verifica, in un'intensità evidentemente maggiore, nei paesi come il Brasile, dove le disparità regionali non appena differiscono gli enti federativi, ma sono la causa di conflitti che possono persino confrontargli, come appunto si verfica nei casi di disputa tributaria tra gli enti.

L'obbietivo di questa dissertazione è segnalare i principali meccanismi nell'ordine costituzionale attuale e, tra loro, distaccare quei che possono essere utilizzati nella armonizzazione dei punti di tensioni decorrenti delle differenze esistenti tra le autonome unità politico ammnistrative delle differenti regioni del Brasile. Si distacca, inoltre che l'incremento di pratiche di cooperazione intergovernative, specie quando il tema riguarda alle politiche pubbiche, torna questa dissertazione interessante all'argomento del constituzionalismo patrio, una volta che il successo delle azioni governative svolte in questo settore dipende direttamente dell'accertamento dell'equazione tra i doveri che debbono essere prestati e la reale possibilità di esecuzione delle funzioni destinate ad ognuno degli enti federativi. Perciò, due linee d'abbordaggio sono state prese.

La prima si concentra nella valutazione critica degli aspetti giuridici della teoria dello Stato federale differenziato. Tale linea investiga le tipologia della differenziazione, eppure studia le possibile consequenze della differenziazione di diritto negli stati territoriali composti. Oltre a ciò, prendendosi come oggetto gli enti autonomi, si presentano i possibili contorni del principio dell'uguaglianza della scena federativa. A sua volta, la seconda linea d'abbordaggio impegnasi nella proposta di analizzare gli aspetti fattibili (storici, socioeconomici, geografichi e politici) legati allo Stato nazionale con la finalità di giustificare l'esigenza di applicazione dei paradigmi intrinseci al federalismo differenziato, nel funzionamento della Federazione brasiliana.

Cosí, dopo la certifica che alcune delle eterogeneità presenti nell'ambiente nel quale lo Stato federale brasiliano si è costruito chiarisce che essi hanno causato problemi i quali si sono riflettuti nello svilupo dei rapporti intergovernativi. Persino si presentano le prospettive per un adequato uso delle competenze costituzionali comuni a tutti, con occhi alla creazione di regioni metropolitani e di istituzioni per lo svilupo regionale, le quale, a sue volte, possono permettere l'inquadratura della Federazione nacionale dentro dei valori contenuti nel federalismo differenziato. 


\section{PAROLE CHIAVE}

Federalismo Differenziato, Federalismo, Stato Federale, Differenziazione, Disparità Regionali, Cooperazione Intergovernative. 